UNIVERSIDADE DE SÃO PAULO

FACULDADE DE FILOSOFIA, LETRAS E CIÊNCIAS HUMANAS

DEPARTAMENTO DE HISTÓRIA

PROGRAMA DE PÓS-GRADUAÇÃO EM HISTÓRIA ECONÔMICA

\title{
AS HIPÓTESES DE MANOEL CORREIA DE ANDRADE: CONTRIBUIÇÕES À HISTÓRIA ECONÔMICA DO NORDESTE BRASILEIRO
}

Rafael Aubert de Araujo Barros

Dissertação apresentada ao

Programa de Pós-Graduação em

História Econômica do

Departamento de História da

Faculdade de Filosofia, Letras e

Ciências Humanas da Universidade de São Paulo para obtenção do título de Mestre.

Orientador: Everaldo de Oliveira Andrade 
Autorizo a reprodução e divulgação total ou parcial deste trabalho, por qualquer meio convencional ou eletrônico, para fins de estudo e pesquisa, desde que citada a fonte.

Catalogação na Publicação

Serviço de Biblioteca e Documentação

Faculdade de Filosofia, Letras e Ciências Humanas da Universidade de São Paulo

Barros, Rafael Aubert de Araujo

AS HIPÓTESES DE MANOEL CORREIA DE ANDRADE: CONTRIBUIÇÕES À HISTÓRIA ECONÔMICA DO NORDESTE BRASILEIRO / Rafael Aubert de Araujo Barros ; orientador Everaldo De Oliveira Andrade. - São Paulo, 2019.

$174 \mathrm{f}$.

Dissertação (Mestrado) - Faculdade de Filosofia, Letras e Ciências Humanas da Universidade de São Paulo. Departamento de História. Área de concentração: História Econômica.

1. Historiografia Econômica do Nordeste. 2 Economia Regional do Nordeste; Geografia Econômica. 3. SUDENE. 4. Urbanização e êxodo rural nordestino. I. Andrade, Everaldo De oliveira, orient. II. Título. 
Resumo: A presente dissertação tem como problemática central a análise do conjunto da obra de Manoel Correia de Andrade e se lugar na historiografia econômica do nordeste. Trata-se de um estudo sobre as contribuições de Manoel Correia de Andrade para a análise históricoeconômica da região do Nordeste brasileiro. Nesse sentido, foi realizado um levantamento do encadeamento científico presente ao longo da vida acadêmica de Andrade buscando identificar as hipóteses propostas por ele acerca do debate histórico-econômico da região nordestina. São descritas o que consideramos três linhas mestras do pensamento de Andrade e que fundamentaram a pesquisa que culminou no presente trabalho: (I) uma seção introdutória; (II) o primeiro capítulo que estuda as influências acadêmicas na formação das obras de Andrade; (III) o segundo capítulo dedicado a explorar a territorialidade econômica das atividades que dominam o espaço do nordeste brasileiro; (IV) o terceiro capítulo com considerações sobre a interpretação de Andrade quanto o fenômeno da urbanização e o êxodo rural; (V) o quarto capítulo que explora e analisa a posição do autor quanto ao plano de superação do subdesenvolvimento executado pela SUDENE.

Palavras-chave: Historiografia Econômica do Nordeste; Economia Regional do Nordeste; Geografia Econômica; SUDENE; Urbanização e êxodo rural nordestino.

\begin{abstract}
:
This dissertation has as central problem the analysis of the whole of Manoel Correia de Andrade 's work and it takes place in the economic historiography of the Brazilian northeast. It is a study about the contributions of Manoel Correia de Andrade for the historical-economic analysis of the Brazilian Northeast region. In this sense, a survey of the present scientific chain was carried out along the academic life of Andrade in order to identify the hypotheses proposed by him about the historical-economic debate of the Northeastern region. We describe what we consider to be three main lines of Andrade's thought, and which ground the research that culminated in the present work: (I) an introductory section; (II) the first chapter that studies the academic influences in the formation of Andrade's works; (III) the second chapter devoted to exploring the economic territoriality of the activities that dominate the Brazilian northeast space; (IV) the third chapter with considerations about Andrade's interpretation of the phenomenon of urbanization and rural exodus; (V) the fourth chapter that explores and analyzes the author's position on the plan to overcome underdevelopment carried out by SUDENE.
\end{abstract}

Key-Words: Economic Historiography of the Brazilian Northeast; Regional Economy of the Brazilian Northeast ; Economic Geography; SUDENE; Urbanization and rural exodus in northeastern Brazil. 


\section{Agradecimentos:}

Agradeço ao CNPq pela bolsa de mestrado concedida que permitiu a execução dessa pesquisa. Agradeço a meu orientador, Professor Doutor Everaldo de Oliveira Andrade pela paciência e compreensão na leitura e correção dos textos que produzi. Também agradeço aos Professores Doutores Agnaldo dos Santos e Luiz Eduardo Simões de Souza pelas recomendações feitas durante o exame de qualificação, eliminando muitas das dúvidas que até então assombravam o desenvolvimento do presente trabalho. Agradeço também aos Professores Doutores José Jobson de Andrade Arruda e Wilson do Nascimento Barbosa, que deram valiosos conselhos e orientações ao longo desta pesquisa. Agradeço, ainda, a meus pais, Adriano Aubert Silva Barros e Rosangela Silvestre de Araújo Barros, pelo suporte e amor incondicionais, e pelo exemplo de vida que me deram, dos quais um dia espero ser digno o suficiente para reproduzi-lo. Por fim, agradeço a meus irmãos Isaac e Daniel, e a meu tio Benício, pelo companheirismo que têm demonstrado por toda minha vida. 


\section{Sumário}

1. INTRODUÇÃO 9

2. CAPÍtUlO 1. O LUGAR DE MANOEL CORREIA DE ANDRADE NA HISTORIOGRAFIA ECONÔMICA DO BRASIL

2.1. INTRODUÇÃO: MANOEL CORREIA DE ANDRADE E OS RUMOS DA HISTÓRIA NO SÉCULO XX 15

2.2. PRINCIPAIS INFLUÊNCIAS 23

2.3. JOAQUIM NABUCO E JOÃO ALFREDO: ABOLICIONISMO E TRABALHO 24

2.4. JOSUÉ DE CASTRO E A GEOGRAFIA DA FOME 26

2.5. EUCLIDES DA CUNHA E OS SERTÕES 29

2.6. CAPISTRANO DE ABREU: A OCUPAÇÃO ESPACIAL 31

2.7. INSTITUT DES HAUTES ÉTUDES DE L'AMÉRIQUE LATINE: TERRITÓRIO, ESTRUTURA E DESENVOLVIMENTO 35

2.8. CELSO FURTADO: FORMAÇÃO ECONÔMICA DO BRASIL _ _ _ _ _ _ 36

2.9. CAIO PRADO E A HISTÓRIA ECONÔMICA DO BRASIL_ $\quad 40$

2.10. AS HIPÓTESES DE MANOEL CORREIA DE ANDRADE 41

2.11. ALGUMAS CONSIDERAÇÕES SOBRE O LUGAR DE MANOEL CORREIA DE ANDRADE NA HISTORIOGRAFIA ECONÔMICA 47

3. CAPÍTULO 2. TERRITORIALIDADE DAS ATIVIDADES ECONÔMICAS NO NORDESTE: DOMÍNIO DO ESPAÇO EM MANOEL CORREIA DE ANDRADE

3.1. INTRODUÇÃO _ _ _ _ _ _ _ _ _ _ _ _ _ _ _ _ _ _ _ _

3.2. ESPAÇO GEOGRÁFICO, ESPAÇO ECONÔMICO E TERRITÓRIO_ $\quad 50$

3.3. O SISTEMA DE DOMÍNIO DA TERRA: O SETOR SUCROALCOOLEIRO $\quad 54$

3.4. O MERCADO INTERNACIONAL DO AÇÚCAR: PRINCIPAIS AGENTES 56

3.5. O MERCADO DE ÁlCOOL COMBUSTÍVEL: O ETANOL COMO MEIO ENERGÉTICO ALTERNATIVO 64

3.6. O AÇÚCAR DE BETERRABA NO MERCADO INTERNACIONAL 68

3.7. UM MERCADO INTERNO POLARIZADO: A DINÂMICA CENTRO-SUL। NORDESTE 71

3.8. AS OUTRAS CULTURAS DO DOMÍNIO DA TERRA 74

3.9. ALGUMAS CONSIDERAÇÕES SOBRE A INDÚSTRIA DO AÇÚCAR E AS DEMAIS ATIVIDADES DO NORDESTE 84

4. CAPÍTULO 3: URBANIZAÇÃO, TERRITÓRIO E SUBDESENVOLVIMENTO NORDESTINOS EM MANOEL COREIA DE ANDRADE,1973 -1998. 86

4.1. INTRODUÇÃO 86

4.2. O FENÔMENO DA URBANIZAÇÃO. 87

4.3. A URBANIZAÇÃO EM DADOS 94 
4.4. O SENTIDO DA PRODUÇÃO URBANA 105

4.5. O DEBATE SOBRE URBANIZAÇÃO: MASSAS MARGINALIZADAS OU POLARIZAÇÃO REGIONAL 106

4.6. A TEORIA DOS POLOS DE CRESCIMENTO: CIDADES QUE MOLDAM REGIÕES 111

4.7. A TEORIA DAS MASSAS MARGINAIS 114

4.8. ALGUMAS CONSIDERAÇÕES SOBRE A URBANIZAÇÃO E SEU DEBATE

5. CAPÍtULO 4. MANOEL CORREIA DE ANDRADE: A SUDENE E O SUBDESENVOLVIMENTO REGIONAL NAS DÉCADAS DE 1960, 1970 e 1980 120

5.1. INTRODUÇÃO 120

5.2. A CRIAÇÃO DA SUDENE 120

5.3. O CONTEXTO DA POLÍTICA ECONÔMICA NACIONAL: O PLANO DE AÇÃO ECONÔMICA DO GOVERNO (PAEG) 122

5.4. MANOEL CORREIA DE ANDRADE E A SUDENE 127

5.5. A QUESTÃO AGRÁRIA: AS VISÕES DE CAIO PRADO E MANOEL CORREIA SOBRE A PROBLEMÁTICA DO FATOR "HUMANO" NO NORDESTE 128

5.6. A SUDENE COMO AGENTE DE EXPANSÃO DO CAPITALISMO 129

5.7. O AGENTE DINAMIZADOR DE CELSO FURTADO E A CRÍTICA DE MANOEL CORREIA DE ANDRADE 133

5.8. OS PLANOS DIRETORES E A AÇÃO DA SUDENE: I PLANO DIRETOR (1961 - 1963) 140

5.9. II PLANO DIRETOR $(1963-1965)$. 144

5.10. III PLANO DIRETOR 146

5.11. IV PLANO DIRETOR (1968 - 1973) 147

5.12. ALGUMAS CONSIDERAÇÕES 149

6. CONCLUSÃO 151

7. REFERENCIAL BIBLIOGRÁFICO 154

8. ANEXOS 159 


\section{Índice de Tabelas}

Tabela 1 produção acadêmica de Manoel Correia de Andrade 42

Tabela 2 produção mundial de Açúcar 1962 - 1982

Tabela 3 volume de Exportações Mundiais de Açúcar Bruto e Refinado - Unidade = milhões de US\$ do ano 2000 61

Tabela 4 valor das exportações de açúcar refinado dos três maiores exportadores do Mundo 1995-2015

Tabelas 5 e 6 número de Usinas por Estado - Região Nordeste - 1981/82 e 2018 65

Tabela 7 produção de Álcool Etanol - Principais Produtores - 1966 a 2015 66

Tabela 8 produção de Beterraba - Toneladas - 1992 a 2016 69

Tabela 9 valores das Exportações de Açúcar de Cana e de Beterraba - 1989 a 2015 70

Tabela 10 produção de Cana-de-Açúcar 1970-2010 em toneladas. 74

Tabela 11 rebanho efetivo do Nordeste por tipo de gado 1975 - 2015 78

Tabela 12 percentual da produção nordestina de Arroz 1975 a 2005 82

Tabela 13 participação percentual da quantidade da produção maranhense de babaçu 1986 - 2005 84

Tabela 14 taxa de fecundidade(filhos/mulher) por situação da região urbana ou rural __ _

Tabela 15 taxa de imigração liquida (\%) 97

Tabela 16 número de municípios por classe de tamanho populacional (\%) 98

Tabela 17 distribuição das Pessoas Economicamente Ativa(PEA) e ocupadas por setor - Unidade = percentual (\%) 100

Tabela 18 valor dos Capitais Residenciais de 1970 a 2000 (unidades= R \$ do 2000) e taxa de variação $(\%)$ 102

Tabela 19 número de Estabelecimentos Rurais por área de ocupada de 1955 - 1980. 126

Tabela 20. Índice L de Theil para a região do Nordeste, anos 1970, 1980 e 1991. 130

Tabela 21 participação percentual(\%) dos programas de investimento da SUDENE - Ampliação da oferta de terra e reorganização do semiárido

Tabela 22 investimentos realizados com política industrial - Unidade $=$ Milhões de Cruzeiros 142

Tabela 23 investimentos com saúde pública e educação básica por esfera pública em milhões de Cruzeiros 143

Tabela 24 percentual da participação setorial na formação bruta de capital fixo 1965 -1967. 144

Tabela 25 investimentos Por Programa de 1963 - 1965 (Milhões de Cruzeiros) 145

Tabela 26 investimentos por programa em milhões de cruzeiros $(\mathrm{Cr} \$)$ 147

Tabela 27 investimentos por programa em milhões de cruzeiros novos ( $\mathrm{NCr} \$$ ). 148 


\section{Índice de Gráficos}

Gráfico 1 participação percentual(\%) dos produtores de cana-de-açúcar na produção mundial de cana-de-açúcar. 56

Gráficos 2 a 7 valores absolutos das exportações brasileiras de açúcar bruto 58

Gráfico 8 evolução do Indicie Médio Anual de Preços da Carne - Ano Base $2002=100 \%$ 1980 a 2011 79

Gráfico 9 população nordestina em regiões urbanas e rurais 95

Gráfico 10 evolução da população total do nordeste e população ocupada na agropecuária (habitantes) 101

Gráfico 11 Nordeste, taxa percentual de urbanização, 1940 - 1991 104

Índice de Quadros

Quadro 1 estrutura dos capítulo de "A Terra e o Homem no Nordeste” 1963 - 2011 48

Quadro 2 Brasil, Nordeste, PIB a custo de fatores(1965/1995) (1965 a 1985 = setor/PIB; 1985 a 1995 = reais deflacionados a preços de 1980) 99

Quadro 3 evolução da esperança de vida no nordeste, 1940 - 1991 103

Quadro 4 superfície e população dos estados nordestinos em 1986 103 


\section{Introdução:}

Este trabalho é resultado de uma pesquisa sobre as contribuições do geógrafo e historiador Manoel Correia de Oliveira Andrade (1922-2007) para a análise da formação econômica do nordeste brasileiro. Trata-se de um trabalho de historiografia econômica que busca compreender como os contextos acadêmicos e os debates contemporâneos condicionaram as reflexões sobre a economia do Nordeste nas interpretações de Andrade e em suas contribuições. A questão central que o presente estudo pretende examinar diz respeito ao lugar do conjunto das obras acadêmicas de Manoel Correia de Andrade na historiografia econômica do Nordeste. Para esse fim foram levantadas as principais hipóteses empregadas por Andrade em sua obra "A Terra e o homem no Nordeste", cada uma delas sendo o tema central de um capítulo.

A historiografia econômica é o ramo da história que visa estudar a natureza da formação das obras de história econômica e de seus autores, partindo das linhas acadêmicas que fundamentam suas interpretações e hipóteses, e como essas evoluíram ao longo da história. Entendemos a historiografia como explicada por Arruda em seu livro "Historiografia: Teoria e Pratica"(2014) no qual o autor considera:

“(A análise historiográfica) Entendida não como a história das obras históricas ou de seu engastalhamento na sucessividade das escolas históricas, mas sim no modo pelo qual os historiadores e as sociedades reconstituíram o seu passado, apropriando-se de sua cultura histórica, campo constitutivo de significados e valores sobre os quais se nutre o conhecimento histórico.”(ARRUDA, 2014, p.20)

Assim, a ênfase está inicialmente nas áreas do conhecimento histórico, geográfico e econômico, de onde Andrade lança sua proposta de interpretação dos fatos geoeconômicos ao longo da história do Nordeste, sejam esses fatos de caráter interno aos espaços nordestinos ou decorrentes de uma diferenciação regional para com o resto do Brasil.

Manoel Correia de Andrade é um dos primeiros estudiosos nordestinos sobre o nordeste a extrapolar a questão da "região-problema". Em praticamente todas as suas obras sobre o Nordeste, Manoel Correia tratou dessa problematização exposta na historiografia tradicional, indo além da visão naturalista, conforme exposta na historiografia do século XIX e início do século XX, a qual caracterizava o Nordeste como, por uma série de razões, ora atribuídas a questões naturais, ora a questões humanas, de inviabilidade crônica para os ideais de progresso e desenvolvimento daquelas épocas. Manoel Correia, partindo do mesmo pressuposto, qual seja, a natureza, estabeleceu-se sobre bases mais sólidas na História e Geografia nordestinas, caracterizando o espaço e o tempo do Nordeste, de maneira a diagnosticar o problema regional de maneira mais profunda e certeira. 
Como um primeiro breve exemplo do impacto de Manoel Correia de Andrade sobre o entendimento da questão supracitada, tem-se que, em sua obra principal, A Terra e o Homem no Nordeste (1963), Manoel Correia divide o território nordestino em três sub-regiões, a saber:

(i) Mata e Litoral Ocidental;

(ii) Agreste e

(iii) Sertão e Litoral Setentrional. ${ }^{1}$

A partir dessa divisão, Andrade realiza a dispersão das atividades econômicas e suas inter-relações. Na região (i), haveria predominância das atividades centrais da economia, com foco para a demanda externa, ou seja, cana-de-açúcar, cacau (na Bahia), e em competição perdida para a cana, o algodão. Em menor escala, dar-se-ia uma pequena cultura de café. $\mathrm{Na}$ região (ii), o Agreste, haveria maior diversidade, em que a pecuária extensiva, desenvolvendose no espaço deixado pela cana, adicionada às culturas de mandioca, leguminosas e grãos, voltadas para o mercado interno e o autoconsumo. Por fim, a região (iii), o Sertão, seria o espaço de predominância da pecuária, está para abastecimento dos centros urbanos e dotada de um papel importante no desbravamento do território do semi-árido e realizada de maneira "ultra-extensiva", termo usado por Andrade para indicar o sistema de criação extensivo com períodos de migração do gado para terras mais férteis e para o mercado consumidor.

Em edições posteriores do livro, Andrade conceberia uma quarta região referente ao meio-norte, para a qual atribuiu características próprias e consequentes da colonização mais tardia que as áreas do litoral e não assoladas pelo polígono das secas.

Nota-se, portanto, que, da "região-problema", caracterizada pela historiografia tradicional até então e pelo ideário meridiocêntrico estabelecido no Brasil desde o início do século XIX, à problematização caracterizada em tempo e espaço por Manoel Correia de Andrade, o Nordeste ganha um novo e singular entendimento a partir das elucubrações daquele intelectual pernambucano.

Manoel Correia de Oliveira Andrade teve uma vasta produção ao longo de sua vida acadêmica $^{2}$. Tratou de uma ampla gama de assuntos pertinentes a História, a Geografia, a Sociologia e a Economia do Nordeste. Nos estudos de Manoel Correia, encontra-se tanto uma

1 Em edições posteriores essa foi dividida em duas regiões: a dos Sertões e o Meio Norte

2 São 137 livros originais, ao longo de 60 anos de vida intelectual ativa. Somando as edições e reimpressões o número de livros atinge 413. 
abrangência temática, como o detalhe pontual, indo da orografia ao elemento humano, do clima à vegetação e fauna, e da agricultura, pecuária e demais elementos da vida material as relações sociais produtivas. Seus livros mais famosos foram as várias edições de " $A$ terra e o Homem no Nordeste" que o autor atualizaria desde 1963 a 2011, "Os Rios-do-Açúcar do Nordeste Oriental" de 1957, "Poder Político e Produção do Espaço" de 1984 , "Reforma Agraria Ainda é Necessária?" de 1985, "Abolição e Reforma Agraria" de 1987, "Modernização e Pobreza” de 1994, "A Questão do Território no Brasil" de 1995, "O Brasil e Questão Agrária" de 2002.

Considerando a produção de Manoel Correia de Andrade de forma ampla, é possível observar que há linhas gerais voltadas a tratar os problemas da região do Nordeste brasileiro, rejeitando a explicação de que os recursos naturais determinariam as estruturas produtivas da região. Para isso, permeiam-se por toda a obra de Manoel Correia de Andrade três problemáticas, a saber: (1) a da territorialidade das atividades econômicas primário exportadoras, (2) a de que o fenômeno do êxodo rural e urbanização seria consequência de forças intrinsecamente ligadas à modernização das estruturas produtivas do Nordeste, e (3) de que os esforços realizados pela Superintendência do Desenvolvimento do Nordeste (SUDENE) teriam sido insuficientes em superar barreiras essenciais ao desenvolvimento do Nordeste.

Dentro do conjunto da obra de Manoel Correia, portanto, é possível identificarem-se três linhas-mestras temáticas. Uma primeira seria o estudo das condições materiais que configuram histórica, geográfica e economicamente o território Nordestino. Uma segunda residiria nos estudos sobre o processo de urbanização "marginalizada", como afirma Manoel Correia $^{3}$. Por fim, uma terceira linha estaria voltada ao estudo das iniciativas do Estado na superação do subdesenvolvimento crônico da região.

Quanto à territorialidade nordestina, aponta Manoel Correia que haveria um domínio do espaço nordestino pelas atividades primário-exportadoras baseadas em uma estrutura arcaica reflexiva de uma concentração de poder político dos herdeiros das antigas oligarquias coloniais. As contribuições para essa linha-mestra podem ser encontradas em "A Terra e o Homem no Nordeste" de 1963, "Os Rios-do-açúcar do Nordeste Oriental” de 1957 e em “Poder político e Produção do Espaço” de 1984.

Para a segunda linha-mestra, da urbanização marginalizada, Manoel Correia argumentou que a participação crescente da população urbana nas décadas de 1980 e 1990 seria absorvida por setores periféricos aos sistemas produtivos primário-exportadores. Dessa

3 Afirmando isso na Obra "O Nordeste e a Questão Regional" de 1993, capítulo 5. Página 53. 
forma, os deslocamentos das populações rurais para o campo seriam fenômenos que criariam um conjunto populacional marginalizado ao centro produtivo e relegado a atividades complementares e ao trabalho informal. Tais estudos podem ser encontrados novamente em “A Terra e o Homem no Nordeste", de 1963, "Modernização e Pobreza", de 1994, "A Questão do Território no Brasil’", de 1995.

A última linha-mestra temática, sobre as ações do Estado para a superação do subdesenvolvimento, analisa principalmente a atuação da Superintendência do Desenvolvimento do Nordeste (SUDENE), criada em 1959, sob a ingerência de Celso Furtado. Nela, Manoel Correia descreve e avalia os aspectos e resultados das iniciativas do órgão nas décadas de 1960, 1970 e 1980, que expandiram a infraestrutura básica do Nordeste, modernizaram a agroindústria e investiram em educação básica e treinamento de pessoal. Entretanto, Manoel aponta que a falha nessas tentativas estaria na forma com que as classes dominantes teriam reagido à ação do Estado, tendo elas absorvido as mudanças, incorporando-as e reproduzindo os elementos de controle das terras, e consequentemente da renda. Os estudos para esse fim podem ser encontrados inicialmente ainda em "A Terra e o Homem no Nordeste”(1963), e posteriormente em “Reforma Agraria Ainda é Necessária?” de 1985, “Abolição e Reforma Agraria” de 1987, em “O Brasil e Questão Agrária” de 2002.

A multidisciplinaridade na formação das influências é o traço característico que permeia todas as linhas-mestras acima mencionadas. Andrade, em todos os temas centrais por ele estudados, busca consubstanciar suas interpretações com relatos específicos das atividades econômicas, do papel do trabalhador na economia, das condições de vida do povo Nordestino partindo sempre de um contexto histórico o qual diz ser essencial para a compreensão acurrada das realidades geoeconômicas de quaisquer região e em qualquer nível de abrangência, seja ele micro, meso ou macro 5 .

Faz-se necessário um exercício de transposição nesse momento do trabalho, para a explicação da razão de ser deste e de seu propósito frente aos próximos passos teóricometodológicos. Não se tem a pretensão aqui de resumir a obra intelectual de Manuel Correia de Andrade a três "hipóteses de trabalho", o que seria um exercício reducionista até deplorável, dado o volume e a riqueza de sua obra, ou até mesmo uma contradição com o propósito deste trabalho. Por outro lado, é necessário um movimento de lâmina de Occam junto ao corpus temático de Andrade para que se possa fazer um recorte interpretativo de suas ideias.

4 O livro em questão ganhará uma seção à parte neste trabalho.

5 Tal posição fica evidente em "Cidade e Campo No Brasil", Capítulo 4. subitem 3. sobre "A importância das condições históricas não pode ser menosprezada." 
Nesse sentido, identificam-se no corpus da obra de Manuel Correia de Andrade três eixos temáticos primários, a saber: território, espaço e ação humana. Tudo acontece e aparece nas obras de Manuel Correia como reflexo da ação humana em um espaço territorializado, ou seja, enquanto estabelecido como lugar de poder, no sentido Raffesteniano (ainda que Manuel Correia nunca lhe tenha referido). Dessa amálgama de elementos, é possível derivar-se um conjunto de hipóteses, quais sejam:

1. Em Manoel Correia de Andrade, as atividades, enquanto ações humanas, se dão em uma territorialidade, ou seja, exercem poder em um espaço dado, o Nordeste.

2. Tais atividades, novamente enquanto ações humanas, se dão caracterizando, através de tais relações de poder, um padrão que pode ser identificado com a reprodução do padrão de subdesenvolvimento no Nordeste.

3. As iniciativas, ou ações humanas derivadas da consciência e desejo de superação do subdesenvolvimento obedecem, elas mesmas, a uma temporalidade e territorialidade próprias.

Tais hipóteses são o objeto de exposição e exame neste trabalho, estruturando mesmo sua forma, como se segue.

A estrutura da presente dissertação é composta por: uma breve seção introdutória, seguida pelo primeiro capítulo leva o nome da temática geral "O Lugar de Manoel Correia de Andrade na Historiografia Econômica do Brasil". O segundo capítulo trata da primeira hipótese tendo como título "Territorialidade das Atividades Econômicas No Nordeste: Domínio do Espaço em Manoel Correia de Andrade.”. O terceiro capítulo discorre sobre segunda hipótese e é intitulado "Urbanização, Território E Subdesenvolvimento Nordestinos Em Manoel Correia De Andrade,1973-1998". O quarto capítulos traz o debate sobre a terceira hipótese identificada sob o título de "Manoel Correia de Andrade: A SUDENE e o subdesenvolvimento regional nas décadas de 1960, 1970 e 1980.”. Por fim temos uma seção dedica as conclusões encontradas no desenvolvimento da pesquisa.

No primeiro capítulo, elabora-se a abordagem do conjunto das obras de Andrade apontando sua capacidade de ser o nexo entre a ciência da história econômica e da geografia econômica, buscando explicar que é no trato dos espaços no tempo que se encontra a principais contribuições de Andrade para historiografia econômica do Nordeste. Nesse capítulo encontra-se também a definição das hipóteses de a serem estudadas nos capítulos subsequentes.

O capítulo segundo traz a análise sobre territorialidade das atividades econômicas no Nordeste e seus domínios. Nesse se explora a conceituação do que seriam os espaços geográficos, econômicos e o da natureza do território. Em seguida há o estudo sobre o papel 
do setor Sucroalcooleiro, partindo da análise do processo de consolidação das usinas de açúcar para posteriormente identificar os agentes do mercado de açúcar. Como a cadeia produtiva da cana se encontra no litoral e na zona da mata e não se adentra no Agreste e no Sertão são também explorados as outras atividades que dominam os espaços no interior do Nordeste.

No terceiro capítulo são expostos os resultados da análise da segunda hipótese de Andrade quanto ao fenômeno de urbanização e êxodo rural. Para isso é definido o que seria a urbanização seguido pelo estudo dos dados referentes ao movimentos populacionais na segunda metade do século XX e início do século XXI. Logo após isso são exploradas as teorias do polos de crescimento e das massas marginais para buscar compreender a visão da época em que a urbanização ocorria sobre o papel do centros urbanos e das consequências do crescimento desorganizado das cidades.

Por fim, temos o quarto capítulo dedicado a estudar a hipótese de Andrade quanto a ineficácia das ações da SUDENE na superação de entreves estruturais para o desenvolvimento econômico do Nordeste. Inicialmente contextualiza-se o processo de criação da SUDENE e seu o ambiente de políticas públicas na qual estava inserido. Posteriormente são discutidos os 4 planos diretores de ação inicial da SUDENE, apontando a forma como esses se alteraram e suas ramificações. 


\section{Capítulo 1. O Lugar de Manoel Correia de Andrade na Historiografia Econômica do Brasil}

\section{Introdução: Manoel Correia de Andrade e os rumos da história no século XX}

Para começar a entender o lugar de Manoel Correia na historiografia econômica é preciso contextualizar seus estudos com o processo geral de evolução das ciências históricas. No século XX, a história passou por um processo de renovação com mudança de paradigma aos historiadores que tinham como objeto de estudo os "fatos históricos" e realizariam o processamento, análise e interpretação desses fatos. Sobre tal mudança, Cardoso afirma:

"A decisiva mudança de rumos ocorreu a partir de 1929, com a criação dos Annales, por Lucien Febvre e Marc Bloch: estes historiadores e cientistas sociais, em geral. Graças a seu estímulo - e ao de F. Simiand, E. Labrousse, J. Meuvret, etc,- começou a evolução que conduziu ao estado presente da historiografia francesa, cuja influência sobre muitos historiadores latino-americanos sempre foi grande.’(CARDOSO, 2002, p. 23)

Com a criação dos Annales na França e com os trabalhos de historiadores como Henri Berr, Paul Lacombe, Lucien Febvre, Marc Bloch, Fernand Braudel, Pierre Vilar etc. o foco da história ampliou-se, incorporando aspectos de outras ciências para tentar compreender uma tendência geral da evolução das sociedades e das economias.

A importância dos Annales na alteração dos rumos da história é descrita por José Jobson de Andrade Arruda quando ao tratar das contribuições de Fernand Braudel aponta:

"Este novo recorte põe na média duração a responsabilidade pela apreensão do sentido da história, uma escala de tempo que medeia entre os 30 e os 50 anos, tempo crítico na percepção histórica porque se instala entre a fugacidade do tempo curto e a secularidade da longa duração. Nesse sentido, Braudel foi o primeiro historiador a romper com a mais antiga e venerável das tradições: a ordem cronológica, (...)"(ARRUDA, 2014, p. 25)

Iniciar-se-ia, sob esse contexto, um novo período historiográfico com foco no estudo amplo dos processos de mudanças sociais, culturais e econômicas das civilizações. Desse ambiente surgem diversas obras de historiadores ao redor do mundo com similar visão da média duração e de sua influência sobra a caracterização da longa duração. No caso da 
América Latina, as contribuições de Caio Prado Junior tratam da história do Brasil da forma ampla tracejando as tendências formadas nos diversos momentos da formação da nação ${ }^{6}$.

A evolução da história econômica como observada no século XX tem seus primórdios nos debates metodológicos do século anterior. Com a primeira revolução industrial fez-se necessário um arcabouço ideológico que justifica-se as pretensões da nova classe burguesa dominante daí surgiram tanto economista e historiadores que descreviam uma marcha para a sociedade de mercado. O debate viria das formas com as quais deveriam ser feitos os trabalhos das ciências sociais, em que direção a ciência como um todos deveria caminhar. Wilson do Nascimento Barbosa aponta dois tópicos fundamentais que foram discutidos na época, seriam esses:“(a) o conflito entre método abstrato e dedutivo contra o método das observações e da indução; e (b) o conflito entre o idealismo e (contra) materialismo.”(BARBOSA, 2009, p. 132)

No início do século XX, os esforços de guerra tornaram cada vez necessária a organização da produção e escoamento de mercadorias, algo que estava tornando se cada vez mais factível em função da crescente contabilização descritiva das economias e das sociedades. Uma das consequências do avanço dos instrumentos estatísticos e contábeis foi a criação de um ambiente propício a estudos históricos baseados em dados empíricos, sobre tal ambiente Luiz E. S. de Souza aponta que:

"Entre a Primeira e a Segunda Guerras Mundiais, no século XX, difundiu-se e intensificou-se a coleta sistêmica de dados quantitativos, especialmente sobre preços e rendas, para o estudo retrospectivo das flutuações da atividade econômica. Iniciava-se uma primeira fase da chamada história econômica quantitativa."(SOUZA, 2007, p. 2)

A evolução do que se reconhece como historiografia econômica quantitativa moderna teve seus primórdios nessa primeira fase, a partir da qual se iniciou um debate que perduraria até os dias atuais sobre a incorporação e utilização de metodologias quantitativas e econômicas dentro da análise histórico-econômica.

Souza apresenta uma categorização das fases da historiografia econômica moderna, dividida em quatro períodos, a saber: (i) uma primeira, 1914 - 1950, associada com as guerras e crises do período, no que Eric Hobsbawm definiria como "Era da Catástrofe"; (ii) uma segunda fase associada à chamada "Era de Ouro" de 1950 a 1970; (iii), uma terceira fase atrelada ao fim da prosperidade da fase passada com período que vai de 1970 a 1990; e, por fim, temos a quarta fase (iv), caracterizada pelo processo de integração econômico e social

6 .Ver: JUNIOR, C. P.: Formação do Brasil Comtemporâneo. São Paulo, Brasiliense, 1961. 
que ficou conhecido como globalização que partiu dos anos 1990 até a atualidade (SOUZA, 2007).

$\mathrm{Na}$ primeira fase, se refletiram as mudanças do paradigma da teoria econômica neoclássica, pois após a crise de 1929 fez-se necessário incorporar períodos de instabilidade econômica anteriormente vistos como impossíveis ou apenas momentâneos. Nessa época se destacaram os estudos de economistas de formação neoclássica como John Maynard Keynes, que em sua Teoria Geral $^{7}$ elaborou uma explicação para os comportamentos dos mercados de trabalho em situações que o pleno emprego não fosse algo garantido. Outro economista representativo do período foi Joseph Alois Schumpeter com a sua Teoria do Desenvolvimento Econômico $^{8}$ na qual a existência dos ciclos econômicos com momentos de crescimento e recessão baseados nas formas dos paradigmas tecnológicos e das dinâmicas inovativas das economias. Além desses, o russo Nikolai kondratieff escreveu, nos anos 1920, "The Long Waves in the Economic Life" trabalho que propõe, pela primeira vez, uma teoria de ondas longas do desenvolvimento do capitalismo.

Wilson Barbosa denota a mudança nos modos de se fazer ciência econômica, em virtude das consequências metodológicas da crise de 1929 a esta:

"No caso da evolução metodológica, a crise geral de 1929-1932 verificou-se ser excelente remédio. Maneiras de focar completamente superadas, focadas num equilíbrio, numa imitação da mecânica física e no desinteresse pelo societário viram-se - ao menos temporariamente - varridas e lançadas fora. Respirou-se o ar da liberdade de pensamento. " Novos tempos demandam novas engenhocas". Como seria de esperar, a história econômica também iria se beneficiar da nova visão crítica criada pelo vento da mudança.”(BARBOSA, 2009, p. 128-129)

Nesse contexto, história e economia, como ciências, tenderam a se aproximar. Os historiadores buscaram criar bases de dados com os documentos disponíveis para guiar suas análises. Já os economistas se interessaram em aplicar os modelos baseados em teorias econômicas nas sociedades, ao longo do tempo.

Com a então crescente produção de dados das flutuações de preços e quantidades, os primeiros trabalhos de história quantitativa estavam focados nos aspectos de conjuntura. As

7 KEYNES, J. M.: A Teoria Geral do Emprego do Juros e da Moeda, Coleção "Os Economistas", São Paulo, 1996 (Originalmente publicado em 1936)

8 No Original: SCHUMPETER, J. A.:Theorie der wirtschaftlichen Entwicklung.Leipzig, Editora de Duncker \& Humblot. 1911. 
flutuações econômicas foram quantificadas e os trabalhos de historiadores econômicos se destacaram por explicar os momentos de crescimento e recessão das civilizações a partir de análises baseadas em dados estatísticos.

A história, revigorada, teria como diferenciadores o seu carácter multidisciplinar e a abordagem continua. Já não seria mais suficiente interpretar somente a esfera dos fatos isolados ou conjunturais, a estrutura como forma de permanência precisaria ser considerada fundamental nas interpretações e nas teorias. Sobre tal ambiente de mudança, Ciro Flammarion Cardoso afirma que:

“O motor da evolução recente da história foi, pois - e continua a sê-lo - o contato com as demais ciências do homem; menos estruturada, a história também se mostra aberta, menos rígida, menos resistente à mudança do que outras disciplinas.”(CARDOSO, 2002, p.24)

É a partir dessa época que podemos observar mais nitidamente o estabelecimento de ramos definidos dos estudos históricos, como a História Social, a História Demográfica, e a própria História Econômica. Esta última surgiu em duas frentes: uma liderada pelas gerações dos Annales. A outra a que viria a ser encabeçada pelos economistas da New Economic History (NEH), escola que buscava equacionar economias passadas a partir da teoria e metodologia da econometria moderna, segundo Souza a NEH:

“Trazia uma mudança de perspectiva à história quantitativa: nela, não se partiria dos dados, mas das premissas constituídas a partir da teoria econômica. Sobre tais bases, realiza-se a formulação matemática de um modelo explicativo do problema proposto. Este modelo pode ser demonstrado, assim, usando-se informação histórica através do emprego da econometria. Tal uso rendeu à vertente da Nova História Econômica a alcunha de Cliometria ou econometria retrospectiva."(SOUZA, 2007, p.7)

A história econômica moderna é o ramo da história que, lançando mão de instrumental teórico e metodológico das ciências econômicas, busca estudar as mudanças e, o que Cardoso denominou de "permanências" das civilizações em suas mais diversas formas de vida material. Outra interpretação da divisão da ciência histórica é de Barbosa que aponta que:

"O surgimento da História Econômica correspondeu, portanto, à necessidade de se abandonar o "método sincrônico" utilizado pelos clássicos para expor a formação das categorias da Economia Política, e adotar em seu lugar uma "abordagem diacrônica", "contínua", das 
ocorrências econômicas na vida das sociedades. A construção de hipóteses explicativas sobre a dinâmica da sociedade ocidental foi seu ponto de partida, com o estudo da chamada "Revolução Industrial", da “Grande Depressão de 1873-1894”, etc., chegando finalmente à discussão dos fatores não dinâmicos em escala mundial."(BARBOSA, 1988, p.4)

Com os estudos sobre a revolução industrial a história dos acontecimentos econômicos tomara uma abordagem que não poderia se conter a acontecimentos singulares com consequência de curto ou médio prazo, as transformações que se desenrolaram no final do século XIX criaram um sistema econômico com a produção industrial no centro de suas operações. A consolidação do capitalismo industrial não é um fenômeno que possa ser condensado em um período representativo, a economia se adapta, modificando muito de seus fundamentos para manter o sentido geral da produção, a saber, no capitalismo, o acumulo de capital.

Paralelamente à evolução da história econômica, a geografia passou por similares redefinições do que seria o foco da ciência. Pesquisadores como André Cholley ${ }^{9}$ e Richard Hartsthorne ${ }^{10}$ expandem os limites da ciência, incorporando aspectos de ciências naturais e humanas na caracterização da terra. Manoel Correia de Andrade, a partir disso, conceitua a Geografia como uma ciência do espaço que:

“(...) lançando mão de conhecimentos fornecidos por ciências afins, naturais, como a Geologia, a Pedologia a Botânica, a Zoologia, a Biologia Geral, a meteorologia etc., e humanas, como a Antropologia, a Sociologia, a Economia e a História, procura descrever as formas visíveis de organização do espaço e da sua utilização pelo homem, explicando o porquê desta organização. Por isso o conhecimento geográfico não é estático; ao contrário, é eminentemente dinâmico, de vez que ao descrever e explicar a organização atual do espaço, ele está preocupado em explicar as causas desta organização, a razão de ser da mesma, estudando a sua evolução histórica e oferecendo indicações das perspectivas para o futuro.”(ANDRADE, 1976, p.18)

Há um processo durante a segunda metade do século XX de aproximação das Ciências Sociais. No caso da história há uma busca pela compreensão da vida material do homem no

9 Cholley, A.: La Géographie, Guide de l'étudaint. Presses Universiteire de France, Paris, 1942.

10 Hartshorne, R.: Questões sobre a Natureza da Geografia. Intituto Pan-americano de Geografia e História, Rio de Janeiro, 1969. 
tempo, suas tendências e suas contradições. Já a geografia econômica estuda o espaço e suas configurações no tempo, suas causas e consequência na vida material do Homem. As questões que conectariam a Geografia Econômica e a História Econômica seriam: (I) qual a natureza dos espaços nos tempos das civilizações? (II) como as economias se organizaram espacialmente ao longo dos diversos momentos históricos? (III) quais os sentidos impostos pelas tendências históricas as transformações dos espaços econômicos?

Embora a história econômica moderna tenha se consolidado no século XX, o método analítico continuo de observação da conjuntura e estrutura remota ao materialismo histórico de Marx e Engels. Partindo da dialética que Hegel e do materialismo de Feuerbach, Marx e Engels elaboraram um método que segundo Barbosa:

"Sucintamente, posso dizer que o Materialismo Histórico é a forma com que Marx e Engels aplicaram o Método Dialético à História, entendendo-o como um método geral para o que chamamos de ciências sociais."(BARBOSA, 1988, p.7)

Andrade foi fortemente influenciado não só pelos estudiosos da escola de Annales, como por Marx e Engels, de maneira que estava sempre preocupado em mostrar as consequências que as estruturas econômicas, em seu sentido permanente, tem sobre a alocação das terras e a qualidade de vida dos nordestinos. Em diversas obras, nas quais se incluí a sua mais renomada "A Terra e o Homem no Nordeste", Andrade utiliza-se de uma estrutura analítica que descreve como o meio ambiente e as relações de trabalho se modificam em dinâmica onde o homem altera a terra em um momento e é condicionado por ela em um momento posterior.

Dessa forma, Andrade assume que um geógrafo economista pode ter lugar no bojo dos historiadores que interpretam os acontecimentos históricos com foco na vida material e seus processos de transformações ao longo do tempo assimilando conceitos da geografia, da economia e da história para tentar explicar o sentido da formação e evolução das sociedades nas sub-regiões do Nordeste.

A pluralidade disciplinar que estava se disseminando nos estudos da história na segunda metade do século XX, influenciou fortemente as pesquisas de Andrade, de fato, o cientista lançava mão de conceitos geográficos, históricos, sociais e econômicos que refletissem com melhor coerência seus objetos de análise. Sempre buscando descrever detalhadamente as mudanças históricas Andrade se aprofundava nas minucias de cada época, isso pode ser visto claramente em sua obra "A Terra e o Homem no Nordeste" na qual o autor 
descreve de forma contínua as transformações das relações de trabalho na hierarquia social Nordestina.

A visão reconstrucionista aplicada pela escola metódica partiria do estudo de fontes documentais na elaboração de suas análises científicas, algo que seria justificado por duas razões: (I) a de que os fatos poderiam ser observados pela percepção indireta por sua capacidade de existir independentemente do historiador, e (II) haveria certa semelhança entre os fatos atuais com os fatos passados, permitindo com isso a sistematização coerente de fatos e períodos históricos (CARDOSO, 2012). Entretanto, os limites epistemológicos da escola metódica seriam inerentes às suas justificativas, na medida que tenderiam a gerar erros de anacronismo, devido à suposta incapacidade da mente humana de se dissociar completamente de seu tempo histórico e social específico.

Manoel Correia de Andrade inicialmente produziu livros voltados a geografia de ensino colegial e fundamental, grande parte desse em coautoria com Hilton Sette (1911 1997), geógrafo escritor de livros didáticos e romancista Pernambucano. Com Sette, Andrade desenvolveu sua habilidade de escritos de geografia humana e física produzindo, desde os anos 1950, até 1980, um total de 8 livros com 224 edições entre eles ${ }^{11}$.

Em paralelo a sua produção didática nas décadas de 1950 e 1960 Andrade se debruçou sobre a problemática do subdesenvolvimento nordestino e brasileiro chegando a apontar em seu livro “Geografia, Região e Desenvolvimento”(1967) que:

"O grande problema do mundo moderno, que preocupa os pensadores e técnicos de quase todos os países é o da diferença existente entre os países desenvolvidos, entre os países industrializados e o chamado terceiro mundo, ou seja, os países subdesenvolvidos. Uma das grandes preocupações dos cientistas sociais, quer sejam economistas, administradores, geógrafos humanos, sociólogos, antropólogos, etc. É

11 .ANDRADE, M. C. De; SETTE, H.: Geografia do Brasil, $3^{a}$ Série ginasial. 1Ed. São Paulo, Editora do Brasil, 1952;

ANDRADE, M. C. De; SETTE, H.: Geografia Geral para $1^{a}$ Série Ginasial. $1^{\text {a} E d . ~ S a ̃ o ~ P a u l o, ~ E d i t o r a ~ d o ~ B r a s i l, ~}$ 1954

ANDRADE, M. C. De; SETTE, H.: Geografia Geral para $2^{a}$ Série ginasial. $1^{a}$ Ed. São Paulo, Editora do Brasil, 1954;

ANDRADE, M. C. De; SETTE, H.: Geografia do Brasil, para a $4^{a}$ Séria Ginasial. $1^{\mathrm{a} E d}$. São Paulo, Editora do Brasil, 1957;

ANDRADE, M. C. De; SETTE, H.: Geografia do Brasil: Região Nordeste. $1^{\mathrm{a} E d}$. São Paulo, Editora do Brasil, 1962;

ANDRADE, M. C. De; SETTE, H.: Geografia do Brasil, Curso Colegial. ${ }^{a}$ Ed. São Paulo, Editora do Brasil, 1965

ANDRADE, M. C. De; SETTE, H.: Geografia Geral: Fisica e Humana. São Paulo, Editora do Brasil, $1^{\text {aaEd. }}$ 1965;

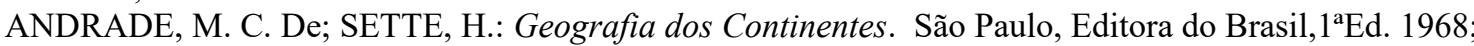


o de caracterizar o que seja o subdesenvolvimento, de vez que vivemos num mundo em que um terço da população vive nos países desenvolvidos, gozando de altos ou de médios padrões econômicos e sociais, enquanto dois terços da população vive em condições de vida abaixo daquelas consideradas mínimas para uma subsistência razoável, para uma subsistência digna.”(ANDRADE,1967, p.13)

Dessa forma em plena segunda fase do desenvolvimento da historiografia econômica, Andrade já escrevia sobre a natureza da diferenciação entre os países ditos de primeiro mundo e de terceiro mundo. A obra supracitada é o esforço inicial do autor em aplicar a teoria de “Aménagements du territoire" da geografia econômica francesa na realidade brasileira ${ }^{12}$. Para tal Andrade lança mão dos casos franceses e israelitas para propor um esquema dividido em três partes: (I) Programação, fase de diagnósticos das estruturas sociais e econômicas das cidades e polos de crescimento; (II) Decisão, fase de elaboração das ações e política a serem executadas; (III) Execução, fase de desenrolamento das ações e fiscalização dos agentes(ANDRADE, 1967).

Manoel Correia de Andrade, como historiador, produziu livros de teor histórico-social com estudos documentais descritivos ${ }^{13}$. Já outros livros publicados, também, nas décadas de 1960 e 1970, seriam caracterizados pelo estudo das estruturas econômicas da região do nordeste brasileiro considerado até então como região subdesenvolvida por força de uma desvantagem natural decorrente das secas que assolam tal área, considerada a uma "região problema.

$\mathrm{Na}$ busca pela fonte da diferenciação entre os graus de desenvolvimento entre as regiões do Brasil Andrade focou na relação entre o as relações de produção e o uso das terras, dessa forma associando aspectos da geografia humana, da geografia econômica e da histórica econômica. Nenhuma de suas obras representa melhor o amálgama das ciências geográficas e históricas do que “A Terra e o Homem no Nordeste" e é nesse sentido que a produção de Andrade encontraria seu lugar na historiografia econômica brasileira.

Considerando então os momentos e temas acima definidos o foco do presente trabalho volta-se para como esta a obra e o pensamento de Manoel Correia de Andrade para com o corpo teórico e metodológico da história econômica, para isso cabe-se, primeiramente, determinar as principais influencia na vida acadêmica de Andrade, contextualizando assim o

12 Como pode ser encontrado nas obras: ANDRADE, M. C.:Geografia, Região e Desenvolvimento. Recife, $1^{a}$ Ed. 1967 e ANDRADE, M. C.: Cidade e Campo No Brasil. São Paulo. Brasiliense, 1ª̃d. 1974.

13 Como são os casos de: ANDRADE, M. C. De: Pernambuco e a Revolta de Pinto Madeira., Recife, Edições do Nordeste, 1953. p. 30; ANDRADE, M. C. De: Movimentos nativistas em Pernambuco: Setembrizada e Novembrizada. Recife, Editora Universitária da UFPE, 1971; Dentre outros. 
ponto de partida de seu trabalhos, posteriormente focando nos avanços e hipóteses levantados pelo cientista.

\section{Principais influências}

As principais influências na formação da obra de Manoel Correia podem ser aglomeradas em três categorias provenientes, a saber: História Econômica, Geografia e Economia.

Da História Econômica, há autores contemporâneos a Andrade como Celso Furtado ${ }^{14}$, Caio Prado Junior ${ }^{15}$, Raimundo Girão ${ }^{16}$, José Antônio Golçalves de Mello ${ }^{17}$ e Capistrano de Abreu $^{18}$.

Quanto à Economia, Andrade nas décadas de 1960, 1970 e 1980 tentou aplicar a teoria dos polos de desenvolvimento criada pelo economista francês François Perroux, com foco no papel das cidades como centralizadoras das atividades capazes de gerar e disseminar o crescimento econômico com a possibilidade de tal crescimento iniciar um processo de desenvolvimento que eliminaria a "diferença de desenvolvimento regional"(ANDRADE,1993) entre as regiões sudeste e nordeste do Brasil.

Andrade realizou, nos anos 1960, pesquisas econômicas em associação com a Superintendência do Desenvolvimento do Nordeste (SUDENE). Com a SUDENE, Andrade, contribuiu para uma série de estudos regionais focados nos levantamentos das características das atividades econômicas da Região, cujos resultados foram sintetizados nos livros "Área do Sistema Canavieiro" publicado em 1988 e "Áreas de domínio da pecuária extensiva e semiintensiva na Bahia e norte de Minas Gerais" publicado em 1982.

Quanto à Geografia na formação de Andrade essa veio a tomar um papel central nas interpretações e estudos do autor. A geografia econômica seria a ciência de onde Andrade partiria, com exceção de textos e livros pontuais. O autor sempre esteve preocupado com a natureza, as características e as consequências dos espaços formados pelos homens e suas consequências nas vidas dos trabalhadores e para com o meio ambiente.

14 Com obras como: FURTADO, C.: A Operação Nordeste. Rio de Janeiro, Instituto Superior de Estudos Brasileiros, 1959, e FURTADO, C.: Formação Econômica do Brasil. Rio de Janeiro, Fundo de Cultura, 1959.

15 Com livros como: JÚNIOR, C. P.: Formação do Brasil Contemporâneo. São Paulo, Brasiliense, 1942; Júnior, C. P.: História Econômica do Brasil, São Paulo, Brasiliense, 1956, e JÚNIOR, C. P.: Contribuição para análise da questão agrária no Brasil. São Paulo, Brasiliense, 1960.

16 Com sua contribuição sobre a História do Ceará em: GIRÃO, R.: História Econômica do Ceará. Fortaleza, Instituto Ceará, 1947 e GIRÃO, R.: Pequena história do Ceará. Fortaleza: A. Batista Fontenelle, 1953.

17 Com estudos como: MELLO, J. A. G. De: Tempo dos flamengos: influência da ocupação holandesa na vida e na cultura do Norte. Rio de Janeiro, José Olympio. 1947 e MELLO, J. A. G. De: Notas acerca da introdução de vegetais exóticos em Pernambuco. Boletim do Instituto Joaquim Nabuco de Pesquisa Sociais, n³. Recife, 1954.

18 Com: ABREU, C. De: Caminhos antigos e povoamento do Brasil. Edição da Sociedade Capistrano de Abreu. Rio de Janeiro: Briguiet, 1930. 


\section{Joaquim Nabuco e João Alfredo: Abolicionismo e Trabalho}

As políticas das capitais são impactantes nas vidas dos trabalhadores rurais do Brasil. Esse fato se evidencia ao longo da história política Brasileira, inicialmente as figuras políticas centrais tomaram suas diretrizes dos mandos da metrópole portuguesa e posteriormente, centros políticos como Rio de Janeiro e, mais atualmente, Brasília. No Nordeste, os principais centros políticos se encontram nas áreas do litoral, seja ele o litoral Setentrional, como é o caso da cidade de São Luiz no Maranhão ou Oriental, casos de Recife, Maceió, João Pessoa, Natal etc.

As decisões tomadas nos centros políticos teriam impacto sobre as vidas dos trabalhadores nas cidades e nas zonas rurais e dessas decisões nenhuma tivera mais impacto sobre as estruturas produtivas do Brasil rural como a de abolir a escravidão. Andrade em seus estudos sobre a formação socioeconômica do Nordeste buscou interpretar as mudanças causadas pela abolição e como tais mudanças se transmitiriam ao longo do tempo histórico condicionando as estruturas produtivas modernas.

Em seus estudos sobre a abolição, Andrade focou-se nas contribuições de dois políticos João Alfredo e Joaquim Nabuco, sobre o primeiro Andrade escreveu:

"Sua contribuição (de João Alfredo) à história do Brasil e à análise de sua atuação em uma formação econômico-social em transição, cheia de entrechoques e de conciliações, é uma oportunidade para o estudo histórico-sociológico e uma contribuição ao conhecimento da problemática brasileira do passado e dos dias atuais. Isto porque a problemática atual tem suas fontes, suas origens, no período que pretendemos estudar.”(ANDRADE, 1988(b), p.18)

Ao escrever a biografia de João Alfredo intitulada "João Alfredo, Estadista da Abolição”, publicada em 1988, Andrade prestou homenagem ao político, mas também apurou sua visão sobre as contradições que se encontravam em choque no final do século XIX e que viriam a culminar no século XX com os movimentos por uma reforma agrária. Transparece da época de transição do trabalho predominantemente escravo para o trabalho assalariado a origem da problemática do que fazer com o contingente de trabalhadores recém-libertos que não possuíam terras próprias e que ainda seriam substituídos por uma mão de obra imigrante. O resultado foi a formação de uma massa trabalhadora marginalizada que se reproduziu até a atualidade, seja na forma do emprego informal ou na forma de prestação de serviços não essenciais para o funcionamento dos principais complexos produtores. 
O outro político em quem Andrade focou nas suas observações do movimento abolicionista foi Joaquim Nabuco. Esse se destacará por sua busca pela abolição mas também por sua luta pela melhor distribuição da propriedade da terra. Havia, então, resistência à tendência de concentração fundiária que remetia aos primórdios da colonização e que se reafirmava com a Lei da Terra de 1850. Sobre os esforços de Joaquim Nabuco, Andrade escreveu:

“Em 1884, Joaquim Nabuco, jovem bacharel em direito, descendente de uma importante família nordestina, e que, na faculdade, se destacara por suas idéias abolicionistas, fez memorável campanha para se eleger deputado pelo $1^{\mathrm{o}}$. Distrito Eleitoral de Pernambuco, em que atacou, de forma mais radical, a escravidão, defendendo a Abolição imediata. Em algumas ocasiões chegou até a condenar não só a propriedade escrava do homem sobre o homem como também a propriedade da terra.(ANDRADE, 1987, p.29)

Sobre o tema da abolição, Andrade reafirma a ideia que havia elucidado em " $A$ Terra $e$ o Homem no Nordeste", de que o controle e a propriedade da terra viriam a moldar as formas das relações de produção e que com isso formaram-se ao longo dos períodos de ocupação do Nordeste espaços econômicos distintos e caracterizados por uma dinâmica regional específica a cada um deles. Andrade escreve que, com a abolição:

"O latifúndio, com respaldo constitucional e legal, podia expandir-se largamente pelo espaço geográfico, desde que as condições econômicas o estimulassem. Nas áreas mais dinâmicas, como aquelas dedicadas à cafeicultura, à agroindústria açucareira e à cultura do cacau, logo foram sendo adotadas relações de trabalho que levavam o trabalhador a tronar-se um assalariado, sob formas e modelos locais e regionais."(ANDRADE, 1987, p. 41).

No período de 1984 a 1988, os livros e textos produzidos por Manoel Correia de Andrade predominantemente, mas não exclusivamente, focaram-se nas questões das lutas sociais e das transformações das estruturas do mercado de trabalho. Dessas, destacam-se seus textos de ciência política com "Poder Político e Produção do Espaço"(1984) e "Classes Sociais e Agricultura no Nordeste"(1985); seus textos de geografia econômica com "Usinas de açúcar e destilarias no Rio Grande do Norte e na Paraíba: agro-indústria canavieira e a produção do espaço "(1988), “O Nordeste e a questão regional"(1988), "Nordeste: Alternativas da agricultura"(1988), "Área do sistema canavieiro"(1988), "Tendências e 
possibilidades do desenvolvimento do Nordeste em seca: Exposição e debates"(1985); e seus livros de História Econômica com "Escravidão e trabalho "livre" no Nordeste açucareiro"(1985), "Lutas camponesas no Nordeste"(1986) e "Abolição e reforma agrária".

\section{Josué de Castro e a Geografia da Fome}

A Geografia foi a ciência de partida de Manoel Correia de Andrade, o pesquisador buscava contextualizar as formas climáticas, geomorfológicas para depois caracterizar o papel do homem no meio em que vive detalhando as relações que se formaram para o trabalhador e o meio ambiente, assunto que ganhara maior importância nos estágios mais avançados de seus estudos, e do trabalhador para com os donos das terras. Na Geografia Andrade lançava mão do instrumental da geografia física somente em carácter descritivo das paisagens formadas no Nordeste. Suas maiores contribuições foram direcionadas a geografia humana e mais especificamente a geografia econômica.

Josué de Castro foi um médico, geógrafo e cientista social cuja as assertivas quanto a fome e ao problema populacional Andrade veio a debater. Castro em sua obra "Geografia da Fome", publicada originalmente em 1946, ao estudar as faces da fome no Brasil, levanta uma visão do Nordeste na qual a riqueza natural seria caracterizada de maneira que "As condições tanto do solo quanto do clima regionais, sempre foram as mais propícias ao cultivo certo e rendoso de uma infinidade de produtos alimentares."(CASTRO, 1984, p.114). Entretanto, em meio a essa riqueza, Castro observou que ainda podia se encontrar famílias em situação de miséria e fome, por duas razões distintas, a saber: primeiramente, no litoral, a fome seria consequência da formação socioeconômica de um modelo de produção primário exportador de Cana-de-açúcar e seus derivados. Sobre tal modelo afirmou:

“(...) a exploração da cana-de-açúcar se processa num regime de autofagia: a cana devorando tudo em torno de si, engolindo terras e mais terras, consumindo o humo do solo, aniquilando as pequenas culturas indefesas e o próprio capital humano, do qual sua cultura tira toda a vida. E é pura verdade. A história da economia canavieira do Nordeste, como em outras zonas de monocultura da cana, tem sido sempre uma demonstração categórica desta capacidade que tem a cana de dar muito no princípio para devorar depois quase tudo, autofagicamente. Donde a caracterização inconfundível das diferentes áreas geográficas açucareiras, com seu ciclo econômico do açúcar, 
com as fases de rápida ascensão, de esplendor transitório e de irremediável decadência.”(CASTRO, 1984, p.117.)

A fome seria, então, um fator social consequente de uma estrutura estabelecida e incapaz, ou despreocupada, com as necessidades básicas de uma parcela significante da população nordestina. Castro deixaria uma interpretação focada nos problemas elementares que levam ao surgimento da fome, jogando luz sobre uma faceta da sociedade que precisaria ser reformada para com isso eliminar a fome de um país cuja abundância de recursos é incontestável. Andrade em sua releitura crítica da obra de Josué de Castro afirma que:

"A idéia que defendeu com mais ênfase foi a de que o Brasil não era o paraíso tropical que muitos autores consideravam; ao contrário, era um purgatório onde vivia uma população mal-alimentada ou esfomeada. Chamava a atenção ainda para o fato de que em algumas regiões a fome resultava da influência negativa das condições naturais como na Amazônia, e em outras ela era provocada por fatores sociais derivados do sistema de colonização, como no Nordeste açucareiro.”(ANDRADE, 2003, p. 75-76)

A segunda razão da fome no Nordeste, segundo Castro, era direcionada à zona do sertão Nordestino, para a qual o geógrafo teria uma visão otimista da capacidade de subsistência da população, não fosse pelo fator das secas. As secas causariam fomes esporádicas e extremas, os recursos naturais no Sertão seriam tão escassos que tornaria sua ocupação impossível, levando a um movimento migratório da população. $O$ fator da meio natural é de tamanha a importância para Castro que o leva a afirma que:

"Se o sertão do Nordeste não estivesse exposto à fatalidade climática das secas talvez não figurasse entre as áreas de fome do continente americano. Infelizmente, as secas periódicas, desorganizando por completo a economia primária da região, extinguindo as fontes naturais da vida, crestando as paisagens, dizimando o gado e arrasando as lavouras, reduzem o sertão a uma paisagem desértica, com seus habitantes sempre desprovidos de reservas, morrendo à míngua de água e de alimentos. Morrendo de fome aguda ou escapando esfomeados, aos magotes, para outras zonas, fugindo atemorizados à morte que os dizimaria de vez na terra devastada.”(CASTRO, 1984, p.176 e 177) 
No peso do contexto natural, Andrade e Castro divergem. Para Andrade, embora as dificuldades das secas sejam um condicionante, o verdadeiro gargalo ao melhoramento das condições de vida do Sertão é a estrutura produtiva que concentra a propriedade das terras para o sistema de criação do gado. Um modelo produtivo antiguado cujas origens estão nos primórdios da ocupação do espaço sertanejo e que limita o espaço dedicado a agricultura de subsistência dos trabalhadores para atender as demandas do gado criado de forma extensiva. Ao descrever a jornada de trabalho dos vaqueiros na década de 1960 Andrade aponte que:

"Êstes trabalhadores prestando serviços por todo o dia, às vezes em jornadas de trabalho que se estendem por mais de dez horas de trabalho, percebem diárias de acordo com a especialidade e a produção de cada um que em média não ultrapassam os Cr\$ 150 . Salários que não lhes podem dar condições de existência, mesmo modestas. A contribuição das lavouras de subsistência à atual social no campo no Nordeste, é quase insignificante, uma vez que os "sítios de moradores" são pequenos."(ANDRADE, 1963, p.223)

Embora com interpretações distintas as causas da miséria no Nordeste, Andrade e Castro têm em comum o mesmo objeto de estudo, a saber, as condições de vida da população nordestina. Andrade ressalta o foco na população ao comentar a forma como Castro estudou o povo pobre que vivia na periferia da cidade de Recife, a qual seria uma:

"(...) preocupação com a situação da população pobre, expulsa das áreas agrícolas do interior e mal localizadas no Recife, aguçou o interesse do jovem médico pelo problema social, levando-o a dedicar parte do seu tempo à análise do problema da população de baixas renda. Em estudo publicado em 1935 sobre condições de vida das classes operárias no Recife, ele demonstrou que um terço da população da cidade vivia em mocambos e se alimentava precipuamente de crustáceos capturados no próprio rio e na maré sobre a qual vivia. Daí a sua concepção do ciclo de caranguejo, de vez que o habitante do mocambo defecava no rio, fornecendo alimento para o caranguejos que, em seguida, capturava para servir de base de sua própria alimentação. Assim, o homem alimentava o caranguejo que iria alimentá-lo. A análise deste ciclo pôde levar a conclusões sérias sobre as relações entre o homem e o meio onde ele vivia e explorava, uma vez que a população desempregada passava a maior 
parte do dia, sobretudo nas horas de maré baixa, mergulhada na lama à procura dos caranguejos para sua alimentação. " (ANDRADE, 2004, p.112)

As condições de vida do povo nordestino são um tema recorrente na produção acadêmica de Manoel Correia. Obras como "A Terra e o Homem no Nordeste"(1963), "Três Ensaios Sobre a Realidade Nordestina"(1967), "Latifúndio e Reforma Agrária no Brasil"(1980), “As Alternativas do Nordeste"(1983), "Lutas Camponesas no Nordeste"(1986) e “O Nordeste e a Questão Regional"(1988) possuem descrições das condições dos trabalhadores e pequenos proprietários no Nordeste, sendo essas reflexos de um limitante econômico definido por um processo de perpetuação de estruturas de produção arcaicas da pecuária no Sertão e da cana-de-açúcar e derivados no litoral.

\section{Euclides da Cunha e Os Sertões}

O livro "Os Sertões: Campanha de Canudos" publicado em 1902 de autoria de Euclides da Cunha é uma obra estruturante das visões que o povo Brasileiro tem do Nordeste e por isso há uma incomensurável gama de trabalhos, interpretações e análises que descrevem e atribuem, por vezes merecidamente, por outras fantasiosamente, méritos como um avanço no registro histórico da região das secas do Nordeste brasileiro. Para esclarecer os objetivos de tal livro histórico não há melhor recurso do que a própria nota preliminar que Cunha acrescentou às edições corrigidas, a partir de 1903. Nela, Cunha explica que:

"Intentamos esboçar, palidamente embora, ante o olhar de futuros historiadores, os traços atuais mais expressivos das sub-raças sertanejas do Brasil. E fazêmo-lo porque a sua instabilidade de complexos de fatores múltiplos e diversamente combinados, aliada às vicissitudes históricas e deplorável situação mental em que jazem, as tomam talvez efêmeras, destinadas a próximo desaparecimento ante as exigências crescentes da civilização e a concorrência material intensiva das correntes migratórias que começam a invadir profundamente a nossa terra. (CUNHA, 1995 p. 1)

Dessa forma, o objeto do estudo do livro foi definido como os povos sertanejos. Estruturado em três etapas, com a última dividida em seis subseções. O livro começa com o tracejo das características das terras do Nordeste em uma seção denominada "A Terra", dividida em cinco capítulos nessa seção Cunha relata as formas geomorfológicas e climáticos que encontrou no seu caminho a Monte Santo, na Bahia. 
Quanto à segunda seção, denominada "O Homem", essa encontra-se dividida, também, em cinco capítulos e trata do relato sobre os povos encontrados por Cunha no Sertão com destaque aos jagunços e suas origens. Cunha compara os vaqueiros jagunços do Sertão aos gaúchos do sul, abordando estes como a "antítese" daqueles, por ambos terem sidos condicionados pela interação com o meio ambiente. No caso dos gaúchos, segundo Cunha, a terra lhe é afável, a sobrevivência pelos frutos das terras é um feito de menor dificuldade; já o sertanejo tem de lutar com a selvageria das secas e de uma terra dura e de difícil cultivo (CUNHA, 1984).

A terceira e última seção de Os Sertões encontra-se dividida em seis subseções, a saber: A Luta; A Travessia do Comboio; Expedição Moreira César; Quarta Expedição; Nova Fase da Luta e Últimos Dias. Nelas são abordados os acontecimentos que transcorreram na guerra de Canudos, que embora deveras importantes para a história da região, não cabem no presente trabalho em maior detalhamento.

As secas seriam as principais dificuldades enfrentadas pelo povo sertanejo, que condicionaria seus determinantes sociais, econômicos e políticos a elas., assim como suas vidas Tal centralidade não havia sido proposta por Cunha, de fato em 1896, ano de início da guerra de Canudos, a pobreza do Norte devido à seca já era de conhecimento comum no Sul, algo que denota Cunha ao escrever:

"As Secas do extremo norte delatam, impressionadoramente, a nossa imprevidência, embora sejam o único fato de toda a nossa vida nacional ao qual se possa aplicar o princípio da previsão. Habituamonos àquelas catástrofes periódicas. Desde a lancinante odisseia de Pero Coelho, no alvorar do século XVII, até ao presente, elas vêm formando, à margem da nossa história, um tristíssimo apêndice de indescritíveis desastres. A princípio, mercê do próprio despovoamento do território, ninguém as percebeu. Notou-as, apreensivo, o primeiro sertanista que se afoitou, naquelas bandas, com o desconhecido; os flagelos revelados mal rebrilham e repontam, fogacíssimos, rompentes da linguagem perra e nebulosa dos roteiros... Depois, à medida que se povoava a terra, cresceu-lhe a influência, e desvendaram-se-lhes os aspectos, deploráveis todos."(CUNHA, 1995(a), p. 153)

As terras dos sertões vistas pelo que posteriormente seria denominado polígono das secas configurariam uma região quase desértica, onde a produção em épocas de chuva seria incapaz de suprir as necessidades dos sertanejos nos períodos de seca. Cunha identifica um 
fenômeno característico da economia sertaneja ao tratar das consequências das secas. Aponta ele:

"Na plenitude das secas são positivamente o deserto. Mas quando estas não se prolongam ao ponto de originarem penosíssimos êxodos, o homem luta como as árvores, com as reservas armazenadas nos dias de abastança e, neste combate feroz, anônimo, terrivelmente obscuro, afogado na solidão das chapadas, a natureza não o abandona de todo. Ampara-o muito além das horas de desesperança, que acompanham o esgotamento das últimas cacimbas."(CUNHA, 1984, p.24)

Os referidos êxodos seriam movimentos migratórios frequentes nos quais os vaqueiros jagunços e meeiros viam-se incapazes de produzir o suficiente para subsistir, os levando a abandonar suas terras em busca de trabalho nas cidades ou nas áreas rurais mais amenas do agreste, do litoral oriental ou nas regiões do sul, sudeste ou centro-oeste. Devido às secas, o Nordeste atualmente é a região do país com menores taxas de imigração liquida ${ }^{19}$.

Essa visão de Sertão é aceita por Andrade apenas parcialmente, concordando que as secas fazem parte importante da vida dos trabalhadores rurais no Sertão. Andrade atribui a disparidade entre o desenvolvimento econômico do Sertão, edo Agreste ,e do Litoral à concentração da propriedade das terras e falta de capacidade de comunicação para com a região da Mata. Sua interpretação é resumida em um trecho de "A Terra e o Homem no Nordeste" onde o autor explica:

“(...)analisando-se a evolução econômica do Sertão, observa-se certa semelhança com o que ocorreu no Agreste. Dizemos semelhança e não identidade porque as dificuldades de comunicação do Sertão com a região da Mata eram bem maiores que as do Agreste, acarretando o encarecimento dos produtos agrícolas, como também dificultando a colocação dos mesmos."(ANDRADE, 2011, p.197)

\section{Capistriano de Abreu - A Ocupação Espacial}

Qualquer estudo que tenha como objetivo compreender a formação dos complexos produtivos das sub-regiões do Nordeste deve ponderar o tradicionalismo inerente às suas atividades econômicas. Seja no caso do setor sucroalcooleiro, como nos sistemas de criação dos diversos tipos de gado, há sempre, com menor ou maior grau, operações cotidianas que

19 Origem da informação: https://seriesestatisticas.ibge.gov.br/series.aspx?t=taxa-de-imigracao-

bruta\&vcodigo $=\mathrm{CD} 102$ 
foram herdadas do conhecimento das sociedades, sendo que este nada mais é do que aquele acumulado nos diversos momentos históricos da formação da sociedade e da economia.

João Capistrano Honório de Abreu(1853 - 1927) foi um historiador Cearense cuja análise da formação do Nordeste se aproxima à interpretação de Manoel Correia em dois principais temas: (I) O papel que a colonização para ocupação do espaço teve na origem dos grandes latifúndios Nordestinos e (II) A natureza simbiótica que a pecuária e a cana-de-açúcar possuíam no período colonial.

Os donatários das Capitanias Hereditárias (1532) seriam os primeiros latifundiários cujas terras seriam a eles atribuídas pela Coroa Portuguesa. A concessão de suas vastas extensões de terras teriam como objetivo a ocupação do espaço em si. Somente com o desenvolver de estabelecimentos prósperos da cana-de-açúcar é que se vislumbrou a possibilidade da produção do açúcar como objetivo da colonização, algo que só veio a acontecer na segunda metade do século XVI.

O controle da capacidade de divisão da terra e o potencial - nem sempre realizado - de ocupação do território colonial era em si moeda de barganha dos donatários que para pagar a coroa, assim como para ganhar seu sustento, entraram em um esquema de sublocação de suas terras, recebendo parte da produção da terra e repassando os dízimos. Abreu descreve o sistema da seguinte maneira:

"Para os donatários poderem sustentar seu estado e a lei de nobreza, eram-lhe concedidas dez léguas de terras ao longo da costa, de um a outro extremo da capitania, livres e isentos de qualquer direito ou tributo exceto o dízimo, distribuídos em quatro ou cinco lotes, de modo a intercalar-se entre um e outro pelo menos à distância de duas léguas; a redízima( $1 / 10$ da dízima) das rendas pertencentes à coroa $\mathrm{e}$ ao mestrado; a vintena do pau-brasil(declarado monopólio real, como as especiarias), depois de ferro de todas as despesas; o dízimo do quinto à coroa por qualquer sorte de édraria, pérolas, aljafares, ouro, prata, coral, cobre, estanho e chumbo ou outra qualquer espécie de metal; todas as moendas d'água, marinhas de sal e quaisquer outros engenhos de qualquer qualidade, que na capitania e governança se vessem a fazer; as pensões pagas pelos tabeliães; o preço das passagens dos barcos nos rios que os pedissem; certo número de escravos, que poderiam ser vendidos no reino, livres de todos os 
direitos; a redízima dos direitos pagos pelos gêneros exportados etc." (ABREU, 2000, p. 66-67)

Em similar interpretação, Andrade atribui a expansão da colônia lusitana ao sistema descrito por Abreu, de maneira a observar a importância dos rios para o desenvolvimento da sociedade nordestina. Como o transporte de mercadoria era essencial para manter a relação primário exportadora com a metrópole, as vias hídricas foram utilizadas para ampliar a disseminação de povoados e cidades pelo interior do Nordeste, sem com isso perder a capacidade de escoamento das mercadorias. Assim, Andrade descreve a expansão territorial inicial do período colonial:

“Com a Grande expansão territorial conseguida, pôde o donatário aquinhoar os seus companheiros com grandes porções de terras em áreas de matas consideradas as mais propícias às culturas, cortadas por rios e riachos perenes e localizadas nas proximidades dos trechos navegáveis dos rios que desembocam no Atlântico, o que permitia o embarque do açúcar produzido para Olinda ou diretamente para o Reino. $\mathrm{Na}$ verdade, os estuários dos pequenos rios tiveram influência decisiva no povoamento, até a construção das estradas de ferro no século passado. Antes destas, cidades localizadas a alguma distância do mar, por trás da área ocupada pelos mangues, no ponto terminal do trecho fluvial navegado, formavam portos para onde convergiam os produtos de grandes áreas do interior. Em função disso tiveram notável desenvolvimento, no século passado (século XIV), Mamanguape, na Paraíba, Goiana e Rio Formoso, em Pernambuco, Porto Calvo e Coruripe, em Alagoas e Maruim e São Cristóvão, em Sergipe.” ( ANDRADE, 1998, p. 61)

É importante reconhecer essa contribuição de Andrade por ela, de fato já se encontra implícita nas obras de Abreu quando esse delimita a história do Brasil em seu primeiro século aos "trechos exíguos de Itamaracá, Pernambuco, Bahia, Santo Amaro e S. Vicente, situados nestas cento e noventa e cinco léguas de litoral." (ABREU, 2000, p. 70) Isso seriam impostos, segundo Andrade, pelo limite de navegabilidade dos rios que adentravam o Agreste e parte do Sertão. Nessa temática Andrade veio a realizar o estudo de história econômica 
sobre até que ponto os rios do Nordeste foram utilizados nos desenvolvimento das atividade dominantes do território ${ }^{20}$.

Outro ponto semelhante entre as análises de Andrade e Abreu é o trato da pecuária como meio de ocupação do espaço. A criação de gado bovino seria a razão pela qual se desbravaria as regiões mais inóspitas do Sertão onde os animais seriam criados soltos pastando nas épocas de chuva e sendo descolados em um movimento migratório para as serras os se alimentariam dos restolhos das modestas agriculturas de subsistência.

Nos engenhos do açúcar o gado tinha função de gerar força motriz, por isso as primeiras propriedades da pecuária surgiram aos redores das áreas dedicadas ao plantio da cana-de-açúcar, tendo dominado os espaços do Agreste só encontrando concorrência pelas terras com o início do surto algodoeiro a partir do século XIX.

O caráter auxiliar, sua capacidade de ocupar longas extensões de terras, fez do sistema de criação do gado perfeito companheiro para a cultura primário exportadora da cana-deaçúcar, ocupando as terras cujos solos não suportavam o cultivo da atividade dominante. Sobre tal simbiose entre a pecuária e a cana, Abreu aponta que:

"O gado vacum dispensava a proximidade da praia, pois como, as vitimas dos bandeirantes a se próprio transportava das maiores distâncias, e ainda com mais comodidade; dava se bem nas regiões improprias aos cultivos da cana, quer pela ingratidão do solo, quer pela pobreza das matas sem as quais as fornalhas não podiam laborar; pedia pessoal diminuto sem traguejamento especial, consideração de alta valia num país de população rala; quase abolia capitais, capital fixo e circulante a um tempo; multiplicando-se sem interstício, fornecia alimentação constante, superior aos mariscos, aos peixes e outros bichos de terra e águas, usados na marinha."(ABREU, 2000, p. $150-151)$

Já Andrade chega a similar conclusão partindo de uma visão centrada nas condições do trabalho. Essa forma de interpretar as estruturas detalhando como um trabalhador comum se integra na produção é um traço característico das obras de Andrade e se destaca em suas obras como distintas como "A Terra e o Homem no Nordeste", onde os primórdios da relação de produção na pecuária no sertão são descritos como:

20 Esses estudos resultaram nos livros:ANDRADE, M. C. de.:Os Rios do Açúcar Nordeste Oriental: O Rio Mamanguape. Recife, Fundação Joaquim Nabuco. 1957 e ANDRADE, M. C. de.: Os Rios-Do-Açúcar Do Nordeste Oriental. Os Rios Coruripe, Jequiá e São Miguel. Alagoas, EDUFAL, 2ª̃d. 2010 (Originalmente publicado em 1959). 
"Nestes sertões desenvolveu-se uma civilização sui generis. Aí os grandes sesmeiros mantinham alguns currais nos melhores pontos de suas propriedades dirigidos quase sempre por um vaqueiro que, ou era escravo de confiança, ou um agregado que tinha como remuneração a "quarta" dos bezerros e potros que nasciam. Outras áreas eram dadas em enfiteuse, os "sítios", que correspondiam a uma légua em quadro e eram arrendados a 10 mil-réis por ano aos posseiros. As grandes distâncias e as dificuldades de comunicação fizeram com que aí se desenvolvesse uma civilização que procurava retirar do próprio meio o máximo, a fim de atender às suas necessidades. Assim, na alimentação usava-se principalmente a carne e o leite, este abundante apenas no "inverno", frutos silvestres e alguns produtos de uma incipiente lavoura de subsistência feita nos brejos, nas vazantes dos rios ou, nos bons invernos, na própria caatinga. Lavouras de ciclo vegetativo curto - feijão, fava, milho etc. - eram confinadas por cercas de varas ou pedras a fim de impedir a danificação provocada por animais." (ANDRADE, 1998, p.170 -171).

A civilização nordestina do Agreste e do Sertão se desenvolveu ao redor de culturas dominantes, onde a propriedade das terras era o fator determinante da riqueza e do poder político. Essas culturas eram controladas pelos seus proprietários, que alugavam o direito de posse a posseiros e meeiros, que, por sua vez, utilizavam as terras com a criação do gado e a pequena lavoura de subsistência.

\section{Institut des Hautes Études de l'Amérique Latine: Território, Estruturas e Desenvolvimento}

Em novembro de 1964, Manoel Correia de Andrade começa um curso pós-graduação e estágio na Université de Paris no institut des Hautes Études de l'Amérique Latine onde, dentre outros cursos diversos, teria estudado a teoria de "Aménagement du Territoire" supervisionado pelos professores Michel Gutelman, Michel Rochefort, Pierre Mombieg e Olivier Dollfus. O estágio terminaria em Julho de 1965 mas seu efeito sobre a produção acadêmica de Andrade se prolongaria pela década de 1960 e tenderia a reaparecer em diversas obras de Andrade, nas quais surgiriam temas como centralidade econômica, pólos de crescimento e regionalização ${ }^{21}$.

21 . Em obras como: ANDRADE, M. C. De.:Polarização para João Pessoa. Recife, UFPE, Faculdade de Arquitetura. Curso de Mestrado em Desenvolvimento Urbano, 1975; 
Após o término do estágio, Andrade escreve e pública a obra "Geografia, Região e Desenvolvimento" em 1967. Nela, o autor faz a conceituação de um programa de planificação econômica regional de longo prazo, referido por Andrade como "aménagment du territoire", com objetivo de realizar transformações de velhas estruturas produtivas em estruturas produtivas modernas. O conceito de estrutura então utilizado é o marxista, na qual essa é definida pelas relações sociais de produção, as formas e modos pelos quais o seres humanos se organizam em uma sociedade para realizar a produção de bens de mercadorias.

A proposta de um "aménagement $d u$ territoire" seria um esforço de geografia econômica voltado a reduzir as diferenças espaciais entras as regiões de uma economia. A nova economia reestruturada com maior integração entre as suas regiões teria maior capacidade de atração de capitais assim como maior capacidade de geração de capitais o que levaria a um aumento direto na taxa de crescimento econômico. Esse nexo entre a disparidade das diferenças regionais e o crescimento global da economia leva a Andrade afirmar que:

"Daí concluirmos que o "aménagement du territoire" é ao mesmo tempo geográfico e econômico. Geográfico porque ele é essencialmente espacial e econômico porque visa elevar os níveis de vida, visa orientar a dinâmica do desenvolvimento a fim de alcançar um equilíbrio entre as várias regiões de um país.’(ANDRADE, 1967, p. 39)

Essa ascendência para com os geógrafos economistas franceses foi suplantado com o interesse de Andrade a aplicar a Teoria dos Polos de Crescimento do economista François Perroux, para investigar o crescimento das cidades no Nordeste, mais especificamente o caso de João Pessoa na Paraíba, assim como a conceituação do autor sobre os temas de espaço geográfico, econômico e território.

\section{Celso Furtado: Formação Econômica do Brasil.}

No debate sobre os entraves para o desenvolvimento do Nordeste poucas figuras chaves se destacaram tanto quanto o economista Celso Furtado, formado bacharel em Ciências Jurídicas e Sociais pela Faculdade Nacional de Direito da Universidade Federal do Rio de Janeiro (UFRJ), doutorou-se em Economia pela Universidade de Paris-Sorbonne.

$\mathrm{Na}$ maioria dos cursos de graduação em economia se encontram pelo menos duas disciplinas de introdução a história econômica, sendo elas a de história econômica geral e a disciplina formação econômica do Brasil. Para o curso de formação econômica do Brasil

ANDRADE, M. C. De.:Espaço, Polarização e Desenvolvimento. Recife, Centro Regional de Administração Municipal, 1967 e ANDRADE, M. C. De.:O Nordeste e a Questão Regional. São Paulo, Ática, 1988. 
poucas são as obras tão influentes quanto "Formação Econômica do Brasil" de autoria de Celso Furtado e publicada em 1959.

Uma analise comparativa entre as mais renomadas obras de Andrade e Furtado, a saber "Formação Econômica do Brasil" e "A Terra e o Homem no Nordeste" revela a similaridade quanto a seus pontos partida de ambas as estudam a cultura da cana-de-açúcar e seu papel na ocupação do espaço e formação da economia e sociedade colonial.

Furtado divide sua análise da formação econômica do Brasil em cinco partes. $\mathrm{Na}$ primeira traz o processo de expansão territorial europeu que, levado a cabo por Portugal e Espanha, teria como objetivo garantir o direito a propriedade das terras do novo mundo. Impulsionados pela pressão que outros países europeus faziam sobre a noção de direito as terras das Américas, Portugal e Espanha iniciará o processo de ocupação sem haver uma plano definido a utilização de tais terras. Sobre a importância de tal fator externo na ocupação do Brasil Furtado afirma:

"Os traços de maior relevo do primeiro século da história americana estão ligados a essas lutas em torno de terras de escassa ou nenhuma utilização econômica. Espanha e Portugal se crêem com direito à totalidade das novas terras, direito esse que é contestado pelas nações europeias em mais rápida expansão comercial na época: Holanda, França e Inglaterra."(FURTADO, 1959, p. 13)

A terra de Santa Cruz teria seu primeiro êxito econômico, com a reprodução dos engenhos do açúcar das ilhas do Atlântico que financiados pelos Holandeses e com mão de obra escrava ganharam parcela cada vez maiores do mercado europeu.(FURTADO,1959) Criar-se-ia um sistema econômico exploratório tanto das terras colonizadas do Brasil como os indivíduos escravizados na África e transportados para trabalharem nas terras produtoras de cana-de-açúcar.

A fundamental diferença entra Andrade e Furtado no tema da economia açucareira colonial é base analítica utilizada com Furtado lançando mão de conceitos da economia na descrição histórica do sistema econômico que se desenvolveu na época. Já Andrade, parte de uma visão histórico-geográfica para descrever os principais empecilhos encontrados pelos primeiros colonos na ocupação do litoral. Focando nas características climáticas e geomorfológicas Andrade relata as consequências que essas tiveram a organização inicial da economia e na problemática da mão de obra apontando que:

“(...) a Produção do açúcar não era apenas uma atividade agrícola; ela requeria certo nível técnico que os escravos negros ou indígenas não 
possuíam. Daí haver tido Duarte Coelho, logo nos primeiros tempos, o cuidado de importar técnicos da Europa, os quais eram quase sempre israelitas. Estes, que nunca se dedicavam à agricultura, mas demonstravam pendores industriais, aproveitavam a ocasião para deixar o Velho Mundo, justamente quando grande era a pressão exercida pela Inquisição contra o povo Judeu.’(ANDRADE, 2011, p.78)

Andrade em "A Terra e o Homem no Nordeste" trata com detalhamentos os fatores humanos e geográficos na evolução histórica da sociedade e na economia Nordestina, dando sempre ênfase as formas de utilização e exploração do trabalho seja ele escravo ou assalariado. Já Furtado por elaborar um estudo sobre a sistemática econômica dos diversos momentos da formação econômica do Brasil dá mais ênfase aos aspectos amplos de cada um dos momentos observados.

Um ponto de encontro entre as obras dos autores seria a abordagem do esgotamento do primeiro ciclo expansivo da cana-de-açúcar no Nordeste. Furtado aponta que os primórdios do período de esgotamento estariam no surgimento das empresas açucareiras das Antilhas. Esse acontecimento consolidado teria em paralelo a maior demanda por escravos, e tenderia a elevar custos e diminuir a rentabilidade dos empreendimentos agrícolas no Nordeste. Furtado, assim, aponta que:

"Na segunda metade do século XVII, quando se desorganizou o mercado do açúcar e teve início a forte concorrência antilhana, os preços se reduziam à metade. Contudo, os empresários brasileiros fizeram o possível para manter um nível de produção relativamente elevado. No século seguinte persistiu a tendência de baixa dos preços. Por outro lado, a economia mineira, que se expandiria no centro-sul, atraindo a mão de obra especializada e elevando os preços do escravo, reduziria ainda mais a rentabilidade da empresa açucareira. O sistema entrou, em consequência, numa letargia secular. Sua estrutura preservou-se, entretanto, intacta. Com efeito, ao surgirem novas condições favoráveis a começo do século XX, voltaria a funcionar em plena vitalidade.”(FURTADO, 1959, p.60)

Andrade, com foco nos movimentos espaciais da atividade da cana, teria interpretação similar. A estagnação perduraria ocorrendo com a gradual substituição da mão de obra escrava pela mão de obra assalariada. Processo esse que se intensificaria com a concorrência externa 
do açúcar das Antilhas e se consolidaria com a abolição da escravatura em 1888. A economia da cana só voltaria a prosperar com o surgimento com a modernização dos engenhos e posteriormente da substituição dos senhores de engenho pelos usineiros. Andrade descreve a importância dos fatores externos afirmando:

“Com a restrição ao tráfico e sua posterior abolição, a Lei do Ventre Livre e a venda de grande parte da população escrava para os cafezais do Sul, que estavam em franca fase expansiva, diminuíam o número de escravos e os trabalhadores assalariados iam aumentando a sua contribuição na produção da indústria açucareira. Certos ofícios como os de pedreiro, carpina, oleiro, tanoeiro etc., ao norte do Recife, eram exercidos por homens livres que muitas vezes residiam em vilas, cidades e povoações. Este fatos que se observava ao norte de Pernambuco era ainda mais sentido no Rio grande do Norte e $n$ paraíba, onde era menor o número de escravos, mas se dava de forma mais atenuada em Alagoas e Sergipe. Tanto que, visitando este Estado em 1859, Robert Avé-Lallemant deparou-se com sua grande área açucareira - a Cotinguiba - com a produção em decadência, devido a falta de braços, à diminuição do número de escravos provocada tanto pelas causas anteriores, como em consequência do surto de cóleramorbo que grassara na região em 1855 e 1856.(ANDRADE, 2011, p.110)

Outra similaridade entre Andrade e Furtado está nos estudos sobre o papel da pecuária no estabelecimento do domínio da cana no litoral e na zona da mata. Para Furtado houve um período de fricção entre os estabelecimentos pecuaristas e os que cultivavam cana, culminando com a proibição da criação em terras do litoral (FURTADO, 2005). Após isso, a pecuária ficaria relegada às regiões não ocupadas pela cana. Assim, Furtado afirma que:

"A criação de gado - na forma em que se desenvolveu na região nordestina e depois no sul do Brasil - era uma atividade econômica de características radicalmente distintas das da unidade açucareira. A ocupação da terra era extensiva e até certo ponto itinerante. O regime águas e as distâncias dos mercados exigiam periódicos deslocamentos da população animal, sendo insignificante a fração das terras ocupadas de forma permanente.’(FURTADO, 2005, p.64) 
Em consonância com Furtado, Andrade propõe que os avanços da pecuária serviriam como reforço ao domínio da cana, ocupando extensas áreas do agreste e "desbravando" o Sertão. Assim, ele afirma que:

"O gado foi sempre um servo da cana; ocupava áreas pioneiras à sua espera e cada vez se distanciava mais do litoral, tendo, consequentemente, que ir alongando cada vez mais suas caminhadas para chegar aos centros de consumo. Foi ele que desbravou e ocupou os vales fluviais distantes de Olinda, fixando-se ao sul, no vale do São Francisco e nos campos de Sergipe e, ao norte, nos tabuleiros da Paraíba e do Rio Grande do Norte. Não fosse a pecuária, os tabuleiros ter-se-iam tornado verdadeiros vazios demográficos e econômicos entre as áreas úmidas e férteis das várzeas.”(ANDRADE, 2011 p. 105)

Com a mudança da centralidade de produção agrícola para a extração mineral do ouro mineiro, há em Furtado um distanciamento dos assuntos estudos por Andrade que passa a traçar as relações de produção nas áreas do Agreste e do Sertão.

\section{Caio Prado e a História Econômica do Brasil.}

No ano de 1994, Andrade publicou sua obra "O Sentido da Colonização" na qual descreveu os efeitos da colonização sobre as estruturas do Nordeste, suas consequências para o meio ambiente e as marcas que ela deixaria sobre a economia nordestina até as décadas de 1920 e 1930. O desenvolvimento de tal obra seria profundamente influenciado pelas contribuições do historiador Caio Prado Júnior principalmente o primeiro capítulo de seu livro "Formação do Brasil Contemporâneo" publicado em 1942.

Ao elaborar sua explicação sobre o "sentido" da civilização brasileira, suas transformações ao longo do tempo e a tendência geral que essas seguiam Prado Júnior produziu um marco no avanço dos estudos de história econômica do Brasil. Ao conceituar que

"Todo povo tem na sua evolução, vista à distância, um certo "sentido". Este se percebe não nos pormenores de sua história, mas no conjunto dos fatos e acontecimentos essenciais que a constituem num largo período de tempo. Quem observa aquele conjunto, desbastandoo do cipoal de incidentes secundários que o acompanham sempre e o fazem muitas vezes confuso e incompreensível, não deixará de perceber que ele se forma de uma linha mestra ininterrupta de acontecimentos que se sucedem em ordem rigorosa, e dirigida sempre 
numa determinada orientação. É isto que se deve, antes de mais nada, procurar quando se aborda a análise da história de um povo, seja aliás qual for o momento ou aspecto dela que interessa, porque último do historiador, por mais particularista que seja.”(PRADO JÚNIOR, 2007, p.19)

A diretiva acima exposta se tornou um tema central no debate da história econômica do Brasil na segunda metade do século XX. Sem dúvida tal forma de estudar os fatos históricos buscando a "linha mestra" dos acontecimentos influenciou a elaboração da obra de Manoel Correia de Andrade. "O Sentido da Colonização" contém não somente o título igual ao primeiro capítulo do livro de Prado Júnior, mas também traz consigo uma forma interpretativa definida a qual Andrade usa para focar na evolução da economia Nordestina e agrega sua análise sobre as condições do meio ambiente.

A mais importante contribuição de Caio Prado para o desenvolvimento das obras de Andrade foi sua encomenda de um livro para publicação na editora Brasiliense em 1963, livro esse que veio a ser a "A Terra e O Homem no Nordeste".

\section{As Hipóteses de Manoel Correia de Andrade}

A vida acadêmica de Andrade foi marcada pela diversidade de áreas de atuação. Tendo formação em direito, história e geografia teria um prolifera produção que não se limitou a só área da ciência social transitando por toda a sua vida entre a geografia, a história e a economia. Em valores absolutos o número de livros, artigos de periódicos e jornais são vastos , com uma diversidade temática quase que constante, só sendo quebrada no começo de sua vida acadêmica quando Andrade produziria livros didáticos para cursos colegiais de geografia.

A tabela 1 traz uma quantificação de dados da produção acadêmica de Manoel Correia de Andrade desde 1952 até 2010. 


$\begin{array}{cc}\text { Livros } & 413 \\ \text { Participações em } \\ \text { Obras Coletivas } \\ \begin{array}{c}\text { Livros Organizados } \\ \text { Prefácios, }\end{array} \\ \begin{array}{c}\text { Apresentações e } \\ \text { Introduções }\end{array} \\ \begin{array}{c}\text { Artigos Publicados } \\ \text { em Periódicos }\end{array} \\ \begin{array}{c}\text { Artigos Publicados } \\ \text { em Jornal }\end{array} \\ \begin{array}{c}\text { Conferências até } \\ \text { 1996 }\end{array} \\ \begin{array}{c}\text { Número de Bancas } \\ \text { na Universidade de } \\ \text { São Paulo }\end{array} \\ \begin{array}{c}\text { Produção Acadêmica } \\ \text { Total }\end{array} \\ \quad 135 \\ \quad \text { Fonte: elaborado pelo autor }\end{array}$

Ao observar a abrangência de seus trabalhos pode-se perceber três enfoques. Primeiro, temos os estudos de caso, onde Andrade realiza estudo de caso de atividades econômicas no espaço Nordestino fixando pequenas zonas geográficas de estudo, chegando no máximo ao nível municipal. ${ }^{22}$

Para além dos estudos de caso, temos uma segunda categoria, relativa à temática dos problemas de diferenciação regional, ampliando o enfoque de seus estudos para o Nordeste como um todo. Nessa categoria temos as mais renomadas obras do autor, como " $A$ Terra e o Homem no Nordeste", "O Nordeste e a Questão Regional" etc. Encontra-se nela o maior número de livros publicados pelo autor, sendo esses também os que mais demonstram teor multidisciplinar ao focar nos problemas do Nordeste em seus aspectos geográficos, econômicos e sociais.

22 Exemplos de tal abrangência são os livros: ANDRADE, M. C. de.: Os Rios do Açúcar Nordeste Oriental: O Rio Mamanguape. Recife, Fundação Joaquim Nabuco. 1957;

ANDRADE, M. C. De: Os Rios do Açúcar do Nordeste Oriental: Os Rios Coruripe, Jiquiá e São miguel. Recife, Instituto Joaquim Nabuco de Pesquisa Sociais, 1959;

ANDRADE, M. C. De: O Homem e a Cana-de-açúcar no Vale do Siriji. Recife, Museu do Açúcar, 1967.

ANDRADE, M. C. De: A Indústria Vinheira no Sul de Minas Gerais. São Paulo, Associação de Geógrafos Brasileiros, 1972;

ANDRADE, M. C. De: Polarizações para João Pessoa. Recife, UFPE, 1975;

ANDRADE, M. C. De: Considerações sobre as relações de dependência entre centro e periferia em áreas metropolitanas: o caso de Recife. Recife, UFPE, 1977;

ANDRADE, M. C. De: Recife: problemática de uma metrópole de região subdesenvolvida. Recife, UFPE, 1979 e

ANDRADE, M. C. De: Recife, Uma Trajetória Secular. Recife, UFPE, 2003 
Quanto ao terceiro enfoque, há os trabalhos que abarcam a problemática do Brasil como um todo. Essa categoria de menor representação tem caráter teorético. Nela, Andrade expõe sua interpretação sobre os principais gargalos econômicos do país, apontando a disparidade entre regiões mais desenvolvidas e aquelas menos desenvolvidas como o principal entrave da economia brasileira como um todo. ${ }^{23}$

Quanto às áreas do conhecimento em que se inserem os livros de Andrade, temos uma diversidade muito mais ampla, com trabalhos de relato histórico ${ }^{24}$, descrição geográfica ${ }^{25}$, obras que mesclam mais de uma área das ciências sociais com foco na geografia econômica ${ }^{26}$ ou na história econômica ${ }^{27}$.

Embora exista uma ampla diversidade temático-objetiva nas obras de Andrade, esse ao tratar do contexto histórico da economia Nordestina concentra sua análise em três linhas mestras. Essas linhas podem ser todas encontradas em "A Terra e o Homem No Nordeste" obra estruturante que consolida e sintetiza os problemas estudados por Andrade. Publicada originalmente em 1963 "A Terra e o Homem no Nordeste" evoluíra conforme Andrade avançava em sua pesquisa, tendo o autor atualizado a obra em 8 edições ao longo de 40 anos.

Acrescida ao longo de suas edições em 5 seções, "A Terra e o Homem no Nordeste" que originalmente era dividida conforme as regiões, passou a incorporar a análise do meio norte com ênfase no estado do Maranhão. Além disso, foi acrescido a ao texto a interpretação sobre as evoluções da economia nacional e mundial sobre as estruturas do Nordeste, com ênfase na consolidação da empresa capitalista nas regiões rurais e da globalização e o processo de integração dos mercados regionais, nacionais e internacionais.

23 Tal ideia pode ser encontrada nos livros: ANDRADE, M. C. De: A Questão do Território no Brasil. São Paulo, Hucitec, $2^{\mathrm{a}} \mathrm{Ed}$. 2004(Originalmente publicado em 1995) e em

ANDRADE, M. C. De:A Questão Nacional e os Desequilíbrios de Desenvolvimento Regional. Recife, UFPE, 1997

24 Como é o caso de: ANDRADE, M. C. De: Pernambuco e a Revolta de Pinto Madeira. Recife, Edições Nordeste, 1953;

ANDRADE, M. C. De: Movimentos nativistas em Pernambuco: Setembrizada e Novembrizada.Recife, UFPE, 1971;

ANDRADE, M. C. De: História das Usinas de Açúcar de Pernambuco. Recife, FUNDAJ, 1989.

25 Com as obras:ANDRADE, M. C. De:Aspectos Geográficos do Nordeste. Recife, SUDENE, 1966 e

ANDRADE, M. C. De: Aspectos Geográficos da Região de Ubá. São Paulo, Associação dos Geógrafos Brasileiros, 1961

26 ANDRADE, M. C. De: Geografia Econômica Do Nordeste: O Espaço e a Economia Nordestina. São Paulo, Atlas, 1970;

ANDRADE, M. C. De: Geografia Econômica do Nordeste: Padrões da Agricultura Nordestina.Recife, SUDENE, 1969 e

ANDRADE, M. C. De: Nordeste, Espaço e Tempo. Petrópolis, Vozes, 1970

27 Como no caso de: ANDRADE, M. C. De: História Econômica e Administrações no Brasil. São Paulo, Atlas, 1976;

ANDRADE, M. C. De:A Agroindústria Canavieira e a Organização do Espaço: Contribuição à História das Usinas de Açúcar de Sergipe. Natal, Cooperativa Cultural Universitária do Rio Grande do Norte, 1990

ANDRADE, M. C. De: Formação Territórial e Econômica do Brasil.Recife, Massagana, 2003. 
As linhas mestras das obras de Andrade podem ser resumida a três hipóteses centrais do autor, sendo elas: (I) A da territorialidade das atividades econômicas primário exportadoras , em suas formas dominação humana organizam o espaço nas regiões de maior qualidade do solo e por tanto de maior rentabilidade econômica, estabelecendo suas territorialidades no espaço do Nordeste; (II) a hipótese de que o fenômeno do êxodo rural e urbanização seria consequência de forças intrinsecamente ligadas à modernização das estruturas produtivas do Nordeste, sem alteração de um sistema arcaico de exploração do trabalho. (III)de que os esforços realizados pela SUDENE teriam sido insuficientes em superar barreiras essenciais ao desenvolvimento do Nordeste.

Quanto à primeira hipótese, essa esta intrinsecamente ligada a uma herança histórico econômica na organização dos espaços e territórios econômicos do Nordeste. Andrade elabora, utilizando de exemplos pontuais ${ }^{28}$ aponta que a estruturação de uma econômica primário exportadora teria efeito condicionante sobre os limites de qualquer outra atividade que venha a surgir no Nordeste. Com ênfase na cana Andrade aponta que:

“(A Cana-de-açúcar) como cultura imperial, apossara-se das terras, conquistara as várzeas de massapê e as grotas de barro vermelho, destruíra as matas, afugentara os animais e só permitia que outras lavouras se desenvolvessem, qual vassala, nas áreas em que ela não podia, nas condições da época, medrar.”(ANDRADE, 2011,p. 104)

Com o domínio do espaço econômico, a cana-de-açúcar relegaria atividades como o cultivo dos coqueirais a zonas específicas dos manguezais e praias, em terras inviáveis ao cultivo da cana. Criou-se então um modelo de utilização das terras nordestinas, dividido em zonas onde impera o cultivo da cana, intercaladas por áreas dedicadas às culturas auxiliares voltadas ao abastecimento dos mercados regionais.

Os fatores de consolidação da indústria da cana no Nordeste não são somente ligados à sua viabilidade econômica, mas também à formação de uma civilização cuja casta política encontra-se intrinsecamente fundamentada na cultura da cana. Isso se reflete na transição dos engenhos para as usinas do açúcar no final do século XIX e na primeira metade do século XX. Devido à pressão da concorrência exercida pela produção paulista, fez-se necessária a modernização dos engenhos nordestinos. Daí, inicia-se o surto usineiro que só pôde se concretizar com auxílio direto dos governos estaduais, que após um momento inicial de

28 Como é o caso relatado por Andrade da importância de Duarte Coelho na consolidação do território da coroa portuguesa no Brasil, assim como a capacidade que o mesmo teve em implementar um modelo de engenho de cana que perduraria até sua substituição pelos engenhos centrais no litoral. 
expansão dos números de usinas, financiaram e estimularam as fusões e realocações das mesmas para áreas de melhor posicionamento (ANDRADE, 2011).

As demais atividades auxiliares do Litoral e da Zona da Mata não dispõem, ou dispõem em menor medida, do suporte de uma comunidade construída para seu melhor funcionamento. As culturas do arroz, do algodão, do coco, pela forma com a qual foram desenvolvidas, não possuem capacidade de pressão econômica e social capazes de mobilizar as forças políticas para garantir suas potencialidades econômicas em momentos de crescimento econômico, principalmente se essas para fazê-lo necessitam de expansão para terras eventualmente ocupadas com a cana. Assim, Andrade aponta que:

"Embora o coqueiro seja planta de grande valor econômico, a ponto de se calcular o valor das propriedades na praia não pela extensão, mas pelo número de palmeiras frutificando que possuem, não moldou uma civilização típica como a cana-de-açúcar e não emprega, permanentemente, grande quantidade de trabalhadores."(ANDRADE, 2011, p.)

No Agreste e no Sertão, as estruturas seriam diferenciadas do Litoral e da Zona da Mata, com o Agreste se destacando pela maior densidade de estabelecimentos de pequeno e médio porte voltados a criação de gado de corte e leiteiro e a agricultura de abastecimento dos centros urbanos(ANDRADE, 2011). Já o Sertão seria dominado pelos grandes latifúndios criadores de gado bovino, que criados de forma extensiva são intercalados por menores estabelecimentos rurais voltados a produção de palma para complementar a alimentação do gado em épocas de seca.

A segunda hipótese remete à problemática das condições de vida do povo nordestino e a desorganização dos centros urbanos nas décadas de 1970, 1980 e 1990. Essa é foi se consolidando ao longo da evolução de "A Terra e O Homem no Nordeste" que em sua primeira edição encontrava-se dividida em 6 capítulos nos quais relatava as características territoriais geográficas e econômicas em um contexto histórico focando nos efeitos da evolução das relações de produção sobre os trabalhadores do Nordeste.

Conforme se processou a modernização das estruturas das usinas ao longo das décadas de 1970 e 1980, Andrade percebeu a intensificação do fenômeno do êxodo rural agregando a "A Terra e o Homem no Nordeste" um sétimo capítulo intitulado "O capitalismo e a evolução recente da agricultura nordestina". Nele, Andrade explica que a modernização da agricultura realizada pelos usineiros seria uma decorrência da instauração de um modelo econômico empresarial capitalista que eliminaria aspectos não capitalistas das relações produtivas no 
Nordeste rural. Como consequência da modernização no campo, criou-se uma escassez de demanda por mão de obra. Tal senário levou Andrade a afirmar:

“Tal desequilíbrio provocou o êxodo rural e o crescimento desordenados das cidades, a princípio de grande porte, e, posteriormente, as de médio e pequeno portes. Estas cidades hoje possuem problemas de estrutura interna de abastecimento, de segurança e de higiene, difíceis de ser corrigidos, e toda a política de desenvolvimento urbano que vem sendo aplicada não pode solucionar esses problemas, porque a sua origem está no campo, que permanece intocado, e não nas cidades. A Situação exacerbou também o processo migratório rural-rural, das áreas de ocupação tradicional para aquelas em ocupação, nas quais os migrantes pobres se estabelecem como posseiros, cultivando lavouras comerciais - o Arroz, por exemplo - e de autoconsumo, como o milho, o feijão e a mandioca."(ANDRADE, 2011, p.245

A natureza da segunda hipótese está diretamente ligada à organização da região rural do Nordeste para com as demais regiões, impactando as zonas urbanas que, com o influxo de trabalhadores, culminam por lançar contingentes populacionais inteiros à margem da economia de mercado, nunca assimilando essa população migrante por completo na força de trabalho industrial. Os trabalhadores rurais, agora marginalizados nas cidades, são relegados aos setores de serviços e comércio ou ao instalável regime do trabalho informal.

Na primeira edição de "A Terra e o Homem no Nordeste", em 1963, Andrade aponta no capítulo 6 sobre "As tentativas de solução da questão agraria", que os planos da SUDENE e a ação da Companhia de Revenda e Colonização (C. R. C.) teriam efeitos incertos, em decorrência do desprezo a um corpo de pesquisa técnico já realizado por pesquisadores nordestinos e da resistência dos usineiros as mudanças propostas quanto a proliferação de empresas rurais de menor porte.

Em sua última edição, a tentativa de superação do subdesenvolvimento já havia se consolidado e o Capítulo 6 de "A Terra e o Homem no Nordeste" passou a ser a análise de Andrade sobre a evolução do espaço econômico e das relações de produção no meio norte. Além disso, Andrade expande sua obra com mais 4 capítulos dedicados as evoluções que influíram a organização econômica no Nordeste. A explicação sobre "as tentativas de solução da questão agrária" ainda se encontra no livro, na forma de um anexo. 
Quanto às iniciativas da SUDENE, Andrade elabora sua terceira hipótese de que os avanços realizados pela superintendência teriam modernizado o setor industrial sem com isso mudar de maneira real a estrutura da economia nordestina. Devido a uma classe política comprometida com os detentores dos meios de produção regionais, quaisquer ações dedicadas à reorganização espacial das atividades econômicas, principalmente aquelas voltadas a reduzir a concentração das terras, encontrariam forte resistência. Andrade, ao estudar a evolução do Nordeste após os planos diretores da SUDENE, chega à conclusão de que:

"O Nordeste, apesar de continuar a ser a região mais pobre do país, conforme provam índices como o IDH, nele vêm ocorrendo modificações que acarretam mudanças formais, embora não promovam um crescimento acentuado e muito menos uma melhor distribuição de renda nem melhoria das condições de vida da população, que continua vivendo em condições precárias. O Nordeste sofre o que poderíamos chamar de um crescimento sem mudanças reais, apenas formais.”(ANDRADE, 2011, p.279)

Não se deve interpretar a hipótese de Andrade como a completa negação de avanços realizados pelas ações da SUDENE na sociedade nordestina. Andrade, já em 1963, acolhia calorosamente as políticas dos planos diretores que visavam a construção de armazéns para produtos agrícolas, assim como os programas que dedicaram recursos a construção de infraestrutura para a educação e a saúde.

\section{Algumas Considerações sobre o Lugar de Manoel Correia de Andrade na Historiografia} Econômica.

A multidisciplinaridade das obras de Manoel Correia de Andrade refletem o contexto do debate no qual esse estava inserido, refletindo também assim sua formação tanto em história como geografia e pós-graduação na Universidade de Paris onde estudou com geógrafos, historiadores e economistas, ganhando uma visão única sobre o processo de formação econômica do Nordeste. Colocando em prática todo o aprendizado acumulado, Andrade realizou estudos sobre os diversos aspectos da economia nordestina com abrangência municipal, estadual e regional.

Os trabalhos de Andrade que mais se destacaram na geografia econômica possuem uma estrutura uniforme. Ao estudar os temas de desenvolvimento, urbanização, políticas econômicas ou economia regional, a ênfase predominante se situa sempre no papel do homem na formação dos espaços e territórios econômicos, aos quais Andrade faz constante referência, 
sempre descrevendo com detalhamento as regiões nas quais uma atividade começa e a outra acaba, ou as regiões em que o domínio do espaço é mais difícil de se delimitar ${ }^{29}$.

O modo de Andrade ver a formação econômica do Nordeste parte dos espaços e regiões geográficas, transbordando para os aspectos sociais relacionados as condições de vida do trabalhador e dos usos da terra. A estrutura da "A Terra e o Homem no Nordeste" evidência a ligação entre a Geografia Econômica e a História Econômica. O quadro 1 expõe as estruturas de duas edições de "A Terra e o Homem no Nordeste", a edição original de 1963 e a $8^{\mathrm{a}}$ edição de 2011 .

\begin{tabular}{|c|c|}
\hline Edição Original de 1963 & $8^{a}$ Edição 2011 \\
\hline 1.Introdução & 1.Introdução \\
\hline 2.O Nordeste: Região e contrastes & 2.O Nordeste: Região e contrastes \\
\hline $\begin{array}{l}\text { 3.A propriedade da terra e a mão-de-obra na região da mata e } \\
\text { litoral oriental }\end{array}$ & $\begin{array}{l}\text { 3.A propriedade da terra e a mão-de-obra na Região da Mata e } \\
\text { do litoral oriental }\end{array}$ \\
\hline 4. Propriedade, policultura e mão-de-obra no Agreste & 4.Propriedade, policultura e mão-de-obra no Agreste \\
\hline $\begin{array}{l}\text { 5. O latifúndio, a divisão da propriedade e as relações de } \\
\text { trabalho no Sertão e no Litoral Setentrional }\end{array}$ & $\begin{array}{l}\text { 5.O latifúndio, a divisão da propriedade e as relações de } \\
\text { trabalho no Sertão e no Litoral Setentrional }\end{array}$ \\
\hline 6.As tentativas de solução do problema agrário & 6.O Meio-Norte e a Guiana Maranhense \\
\hline - & $\begin{array}{c}\text { 7.O Capitalismo e a evolução recente da agricultura } \\
\text { nordestina }\end{array}$ \\
\hline- & 8.O Nordeste e o impacto da globalização \\
\hline- & 9.O Nordeste no limiar do século XXI \\
\hline- & 10.O sentido da modernização no Nordeste \\
\hline- & Anexo - As tentativas de solução da questão agrária \\
\hline
\end{tabular}

Fonte: Elaborado pelo autor.

O lugar de Manoel Correia de Andrade na historiografia econômica do Brasil está, assim, em suas contribuições para a interpretação dos espaços econômicos no tempo. É o modo de ver como as relações de produção evoluem dentro dos territórios de influência das atividades econômicas dominantes. Tal forma de pesquisar fortalece a análise da geografia econômica dando-lhe contexto histórico-econômico e agrega a história econômica a permitindo o estudo da evolução das atividades econômicas pelos espaços que ocupam.

29 Como é o caso do Agreste, zona caracterizada no capítulo 4 de "A Terra e o Homem no Nordeste" como transitória entre a Zona da Mata e o Sertão 


\section{Capítulo 2. Territorialidade das Atividades Econômicas No Nordeste: Domínio do Espaço em Manoel Correia de Andrade.}

\section{Introdução.}

O Nordeste brasileiro tem uma extensão territorial mais de $1.542 .000 \mathrm{~km}^{2}$ englobando 9 estados do Brasil, com uma população total de 53.59 milhões de habitantes. São aproximadamente $18 \%$ do território, um terço dos Estados, e $26 \%$ da população nacional ${ }^{30}$. Foi objeto de uma enorme gama de trabalhos acadêmicos e técnicos focados no estudo dos seus diversos aspectos econômicos, muitos deles voltados a exploração das potencialidades econômicas da região, assim como na delimitação dos principais entraves ao crescimento e desenvolvimento socioeconômicos no interior de suas diversas sub-regiões.

Manoel Correia de Andrade dispendeu grande parte de sua vida e de sua obra estudando as formas da sociedade e da economia Nordestina. Ao longo do seu processo de formação, Andrade esteve sempre focado nos contextos naturais, históricos e sociais que, unidos, condicionam seus espaços geográficos, econômicos e territoriais, assim como os impactos de tais economias do nordestino. A cultura da cana-de-açúcar possui maior significância na formação do Nordeste, e essa foi objeto de diversas obras de Andrade $^{31}$

O cultivo da cana-de-açúcar vem sendo praticado na região nordeste do Brasil desde de o século XVI, quando feitorias como a de Itamaracá remetiam açúcar bruto de engenho a metrópole portuguesa na década de 1520 (ANDRADE, 2011). Somente a partir da segunda metade do século XVI, com a expansão das áreas colonizadas em direção ao sul realizada por Jorge e Duarte Coelho de Albuquerque, é que a cultura da cana tomaria escala suficiente para se tornar uma atividade de significante rentabilidade a coroa lusitana.

30 Dados do IBGE, 2017.

31 Como: A Cana-de-Açúcar na Região da Mata Pernambucana publicado em 2002; Modernização e pobreza: a expansão da agroindústria canavieira e seu impacto ecológico e social publicado em 1994; Usinas e Destilarias nas Alagoas publicado em 1992 com segunda edição em 2010;A agroindústria canavieira e a organização do espaço: contribuição à história das usinas de açúcar de Sergipe publicado em 1990; História das Usinas de Açúcar de Pernambuco publicado em 1989, dentre diversas outras. 
No processo de formação da economia da cana-de-açúcar colonial voltada à produção de açúcar de engenho empregou-se inicialmente mão de obra escrava indígena. Conforme o cultivo da cana tomou uma escala ampla, ocupando as áreas que no século XVI eram viáveis, a saber, toda a extensão do agreste e do litoral ocidental, partindo de Penedo, no atual estado de Alagoas, até as terras do engenho Jerônimo de Albuquerque no Rio Grande do Norte (ANDRADE, 2011), surgiu a necessidade de maior volume de mão de obra e com isso se intensifica o tráfico de escravos negros do continente africano, formando com isso os primórdios de uma classe pobre. Ao mesmo tempo que os senhores de engenhos precisavam de mão de obra para realizar o trabalho braçal que não necessitaria de muita conhecimento, havia, também, a necessidade de pessoas capazes de projetar e fiscalizar a construção com isso pôde se observar um influxo de imigrantes Israelitas, formando com isso os primórdios de uma classe média(ANDRADE,2011).

Formar-se-ia, também, na segunda metade do século XVI o pólo produtor de cana-deaçúcar ao redor de Salvador, limitado a uma área centrada no recôncavo baiano. A partir dos dois espaços produtores de cana-de-açúcar da colônia brasileira dos séculos XVI e XVII se formaram território de domínio que deixaram traços nas economias nordestinas que podem ser encontrados na atualidade, a constar, o grande latifúndio, o foco na produção para exportação e a utilização das terras mais férteis e com maior disponibilidade de recursos hídricos pela cadeia produtiva da cana-de-açúcar, que propicia a uma casta dominante poder alocativo e de domínio político.

O presente capítulo aborda a interpretação de Manoel Correia de Andrade quanto aos territórios e espaços do nordeste Brasileiro. Para tal, faz-se necessário, primeiramente, levantar os conceitos de espaço e território que Andrade utiliza para embasar suas interpretações. A partir deles, passamos à caracterização do contexto internacional e nacional da cana-de-açúcar, buscando estabelecer o papel que a cadeia produtiva da cana-de-açúcar e do álcool do Nordeste para com as demais regiões do Brasil. Por fim, é realizada a análise dos demais territórios econômicos complementares e paralelos ao território da cana-de-açúcar.

\section{Espaço Geográfico, Espaço Econômico e Território.}

Para entendermos as formas de domínio socioeconômicas que Andrade atribuiu as atividades econômicas do Nordeste faz-se necessário analisarmos as categorias utilizadas pelo professor na formação de sua visão sobre o espaço, o território e as sociedades. No debate sobre a classificação do espaço, Andrade diferencia o que seria o espaço geográfico e o 
espaço econômico para com isso observar as propriedades individuais, assim como, a maneira pela qual o espaço econômico age sobre o espaço geográfico.

"Achamos que ele se determina pela situação de um ponto de uma área. Está ligado a certas unidades, como à nação, à região ou ao próprio Estado. Daí levar em conta, para se caracterizar um ponto ou uma área, uma série de elementos, como latitude, a longitude, a altitude, a posição central ou periférica, a proximidade ou o afastamento do mar, as facilidades de acesso ou o grau de isolamento, as características e as direções das linhas de circulação. Também não pode ser esquecido pelo geógrafo o traçado das fronteiras entre os vários Estados independentes. Isto porque, embora saibamos que as condições naturais independem das fronteiras políticas, de vez que estas são muitas vezes traçadas de forma arbitrária, devido às contingências históricas e políticas, sabemos, porém, que elas têm uma grande influência na organização do espaço, feita pelo homem."(ANDRADE, 1970, p. 20 e 21)

O espaço geográfico então seria determinado por fatores de natureza física, histórica e política. Entretanto, esse tipo de espaço limita o que se pode estudar sobre uma sociedade a suas fronteiras. $\mathrm{O}$ espaço econômico iria além das fronteiras dos estados, sendo determinado pelas formas de interação do homem com os recursos disponíveis e historicamente. Precisarse-ia, assim, observar a formação econômica e social do Nordeste e suas repercussões sobre os modos de produção da região. Milton Santos chega a uma observação similar ao apontar que:

"Daí a categoria de formação Econômica e Social (FES) parecer-nos a mais adequada para auxiliar a formação de uma teoria válida do espaço. Esta categoria diz respeito à evolução diferencial das sociedades, no seu quadro próprio e em relação as forças externas de onde mais frequentemente lhes provém o impulso. A própria base da explicação é a produção, isto é, o trabalho do homem para transformar, segundo leis historicamente determinadas, o espaço com o qual o grupo se confronta. Deveríamos até perguntar se é possível falar de Formação Econômica e Social sem incluir a categoria do espaço. Trata-se, de fato, de uma categoria de Formação Econômica e 
Social, tal qual foi interpretada até hoje. Aceitá-la sem levar em conta o espaço levaria a aceitar o erro de interpretação dualista das relações Homem-natureza.’(SANTOS, 2005, p.22)

Com base na evolução das relações do homem nordestino com a natureza pode-se determinar que o espaço econômico trata de um espaço geográfico, onde se observa um traço geral da organização das atividades econômicas em um dado momento histórico. As formas da cadeia da cana-de-açúcar no litoral oriental do Nordeste seriam um bom indício da existência de tal zona. Nessa região, do norte da Bahia até o Rio Grande do Norte, temos o cultivo extensivo da cana-de-açúcar para a produção de açúcar bruto, açúcar refinada e etanol. Há, também, no litoral, atividades de caráter complementar e transitório, como são os coqueirais alagoanos, cultura que intercala as terras usadas com o plantio da cana. Andrade descreve o espaço econômico como sendo aquele que tem "duas características do espaço econômico, que muito bem o identificam: a) é descontínuo e b) é setorial."(ANDRADE, 1970, p. 33).

Coordenando os espaços econômicos de qualquer região estão os territórios das principais atividades dos mosaicos social-econômicos, sendo esses as configurações em zonas de atividades específicas ao longo do espaço de maneira complementar ou suplementar as demais atividades. Os territórios de culturas dominantes, assim, são capazes de mudar as culturas que a tangenciam e que são desenvolvidas visando principalmente auxiliar ou ocupar o espaço, para que a cultura primordial do sistema mantenha-se no domínio. No caso do Nordeste brasileiro, essa dinâmica se evidencia com a cultura da cana-de-açúcar e sua cadeia produtiva no litoral e do sistema de criação de gado "ultra-extensivo" em campo aberto ${ }^{32}$. Com isso Andrade define o conceito de território como sendo:

“(O território) não deve ser confundido com o de espaço ou de lugar, estando muito ligado à ideia de domínio ou de gestão de determinada área. Assim, deve-se ligar sempre a ideia de território à ideia de poder, quer se faça referência ao poder público, estatal, quer ao poder das grandes empresas que estendem os seus tentáculos por grandes áreas territoriais, ignorando as fronteiras políticas."(ANDRADE,2004 p. 19)]

32 Categoria definida por Andrade como um sistema de criação caracterizado pelo gado criado solto nos campos de pastagem com períodos regulares de migração para fugir da escassez de alimentos e para chagar ao local do abate. Tal definição pode ser encontrada em Geografia Econômica p.208 
Andrade utiliza-se, então, de metodologia multidisciplinar ao estudar a região Nordeste tomando noções da geografia humana e física na definição e categorização dos espaços mas não se limitando a isso, interpreta como agentes econômicos exercem sua capacidade de alocação do recurso mais abundante e essencial a econômica nordestina, a terra.

Outro geógrafo que estudou as capacidades dos agentes dominantes de exercer influência direta na organização das regiões vizinhas foi Milton Santos que, em seu estudo sobre a as relações entre os centros urbanos e a zona rurais aponta:

“Atualmente as relações entre as sociedades e seu espaço-suporte não mais têm caráter privilegiado mas dependem de uma determinação externa que tem o domínio deste espaço, da orientação de sua produção e do destino de seus habitantes.’'(SANTOS, 1979, p. 112)

As duas interpretações, de Santos e Andrade, se conectam na medida em tratam das formas de alocação dos fatores produtivos, trabalho e terra, sendo determinada por um sistema de forças externas, colocando qualquer cultura que não seja a dominante a mercê de choque externos causados pelas determinações dos gestores dominantes. Para Santos as determinações seguem o sentido Cidade-Campo, para Andrade as determinações seguem o sentido cultura dominante - Cultura suplementar.

Partindo de suas noções de espaço econômico e território, Andrade passa a estudar como seriam organizador os espaços e território do Nordeste brasileiro, em " $A$ Terra e o Homem no Nordeste" Andrade elabora a sua interpretação de como os territórios, do que veio a denominar de "mosaico nordestino", alocam suas terras e tratam seus trabalhadores nos diversos momentos históricos de suas formações.

Ao descrever a economia dos coqueiras, do cacau e os surtos algodoeiros e de rizicultura, Andrade detalhará os espaços econômicos regidos dentro dos territórios das culturas dominantes e que formariam o "mosaico nordestino"(CARVALHO, 2014), conceito derivado do conceito de mosaico regional da geografia, que adaptado veio a representar as zonas das diversas atividades empreendidas no Nordeste, dando ênfase as diferentes configurações das relações de produção e trabalho que as caracterizam nos diferentes estágios da formação econômica do Nordeste. Trata-se, então, de uma análise que não se atém ao instrumental metodológico de uma só ciência. 


\section{O Sistema de Domínio da Terra: O Setor Sucroalcooleiro}

Com a decadência dos engenhos banguês ${ }^{33}$ que se mostram incapazes de modernizar economia do açúcar no final do século XIX, surgiram as primeiras usinas de açúcar, tendo os seus proprietários, os usineiros assumindo o papel de capitalista modernizador. O açúcar de usina, refinado teria maior acesso a mercados internacionais e os governos dos estados passaram a fomentar a disseminação das usinas através de empréstimos para investimento em maquinário (ANDRADE, 2011), foi nesse moldes que o Nordeste veio a formar a atividade que ainda hoje é a maior atividade exportadora do estado de Alagoas e que tem significância na pauta de exportação de Pernambuco ${ }^{34}$.

Andrade, em sua obra "Nordeste, Espaço e Tempo" define a área do sistema canavieiro Nordestino do século XX como:

“(...) observamos que a cana-de-açúcar ocupa as áreas da mata situadas na proporção oriental da região onde domina um clima quente e úmido com chuvas de outono-inverno. Ocupa sobretudo a chamada zona da Mata de Pernambuco, Alagoas, Paraíba, Sergipe e Rio Grande do Norte.”(ANDRADE,1970, P. 90)

Essa área se expandiu desde a década de 1970, com a criação de dois novos pólos de produção da cana-de-açúcar, o primeiro localizado no oeste baiano limitado ao norte pelo município de Pilão Arcado, ao sul por Malhada, ao oeste Correntina e leste por Jussiape. O outro novo pólo, de menor porte, tem seu epicentro no município de União, na fronteira entre os estados do Maranhão e Piauí.

O novo sistema que veio a se estabelecer causou: (I) a intensificação do processo de migração para os centros urbanos, (II) a maior disseminação dos grandes latifúndios, concentrando assim a propriedade das terras voltadas à agricultura, que só se desconcentrou à medida que órgãos governamentais como a SUDENE implementaram políticas de expansão das terras utilizáveis na pecuária e agricultura familiar, e por fim (III) a transformação dos senhores de engenhos em fornecedores da matéria-prima. Como afirma Andrade:

33 Os engenhos denominado de "banguês" eram aqueles que utilizavam força motriz animal, humana e, em alguns casos, rodas d'água para produzir açúcar mascavo. Diferentemente dos engenhos, as usinas utilizamse de maquinário industrial para a produção do açúcar refinado, do açúcar cristal e no destilo do álcool.

34 Para o estado de Alagoas a exportação de açúcar significou em 2018 57\% do valor das exportações, Pernambuco teve, no mesmo ano de 2018, Para Pernambuco a atividade representou 5,3\% do valor das exportações em 2018.(Fonte dos dados:http://www.mdic.gov.br/comercio-exterior/estatisticas-de-comercioexterior/comex-vis/frame-uf-produto?uf=al) 
"A usina deu margem ao aparecimento de uma nova figura na paisagem açucareira do Nordeste, a do fornecedor de cana, sucesso do banguezeiro. O Antigo senhor-de-engenho, ao desmontar seu velho banguê, de bueiro quadrado e baixo, sempre localizado na meia encosta, transformou-se em fornecedor-proprietário. Sua figura de produtor da matéria-prima para a fábrica de outrem lembra, guardadas as proporções, a figura do lavrador da era colonial, assemelhando-se o atual usineiro ao antigo senhor-de-engenho .”(ANDRADE, p.123)

Assim, chegamos à "modernidade", com uma cadeia de cana-de-açúcar expandida pelas usinas de refino do açúcar. Essas tiveram uma fase de renovação nas décadas de 1970 e 1980, auxiliadas pelas politicas de incentivo a produção e consumo do álcool introduzidas pelo programa PROÁLCOOL em 1975.

Nas décadas de 1990 e 2000, os mercados de açúcar e álcool se modificaram devido a extinção do Instituto do Açúcar e do Álcool (IAA), instituto federal criado em 1933 no governo de Getúlio Vargas, e voltado à elaboração de planos e políticas de incentivo às safras de cana-de-açúcar, à produção do álcool e à aguardente. Com o fím do IAA, em março de 1990, a indústria passou a competir abertamente no mercado internacional (ALVES, 2004).Andrade descreve a comercialização do açúcar e do álcool sob a ação do IAA nas seguintes condições:

“(...) Não é feita de forma livre, com os preços oscilando no mercado,
ela é contratada por organismos internacionais e por convênios e
tratados que estabelecem cotas de aquisições para os países
compradores e de mercado certo para os países
produtores.”(ANDRADE, 1988,P. 34)

A partir de 1991, observa-se que o comportamento das exportações Brasileiras de açúcar tornaram-se imbricadas com as flutuações do mercado mundial tendo forte representação sobre a tendência mundial dos volumes de exportação do mercado internacional do açúcar (OLIVEIRA et al, 2017), denotando a importância da produção brasileira no mercado global. Andrade, em sua obra "Área do Sistema Canavieiro", publicada pela SUDENE em 1988, levantou a assertiva de que não se poderia estudar os mercados regionais brasileiros e internacionais do açúcar separadamente (ANDRADE, 1988). Dessa forma, o Brasil - e o Nordeste - teria importância fundamental para o bom atendimento da demanda 
mundial de açúcar e álcool, na mesma medida teriam, como atividade primário exportadora, sua oferta, principalmente, voltada ao exterior.

\section{O Mercado Internacional do Açúcar: Principais Agentes}

Para caracterizar o mercado mundial de açúcar, é preciso compreender que a demanda de tal é indiferente quanto à diferenciação de açúcar de cana e açúcar de beterraba. De fato, o açúcar da cana brasileira tende a competir com o açúcar da beterraba francês nos principais mercados consumidores como a Índia, a China e os países do Oriente Médio. Outro aspecto que também precisa ser levado em consideração são os demais produtos resultantes da cadeia produtiva do açúcar, principalmente o álcool combustível etanol.

Quanto a produção de cana-de-açúcar a produção brasileira vem se destacando desde meados do século XX, sendo representativa de maior parte da produção mundial. O gráfico 1 expõe a significância percentual da produção de cana dos maiores produtores para com o mercado mundial, no período de 1961 a 2015.

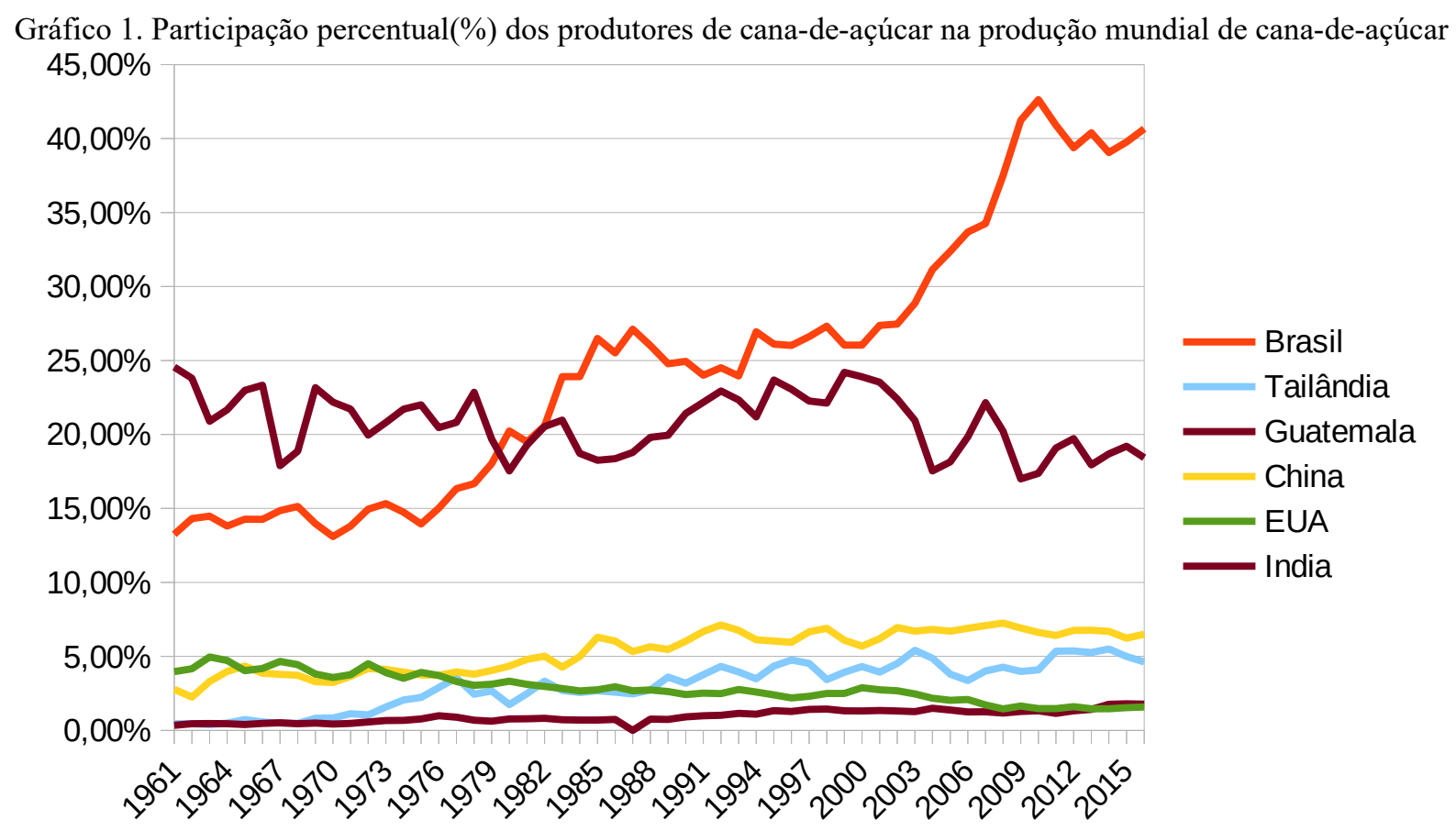

Fonte: www.factfish.com

O gráfico nos mostra um cenário no qual a produção brasileira, que na década de 1960 já representava a segunda maior mundo, cresceu significativamente, mostrando tendência constante de alta, ganhando impulso a partir de 1973/1974, devido à criação do PROÁLCOOL programa que gerou maior demanda por cana-de-açúcar com finalidade de ser matéria-prima na produção do álcool combustível. Na década de 1980, a indústria da cana 
continuou sua trajetória crescente impulsionada pelo mercado interno, que, com o choque da crise do petróleo de 1979, observou maior demanda por combustíveis alternativos a gasolina, o que aumentou a procura pelo álcool combustível e consequentemente a procura por maior produção canavieira.

Nos últimos anos da década de 1980, os resultados da crise inflacionária generalizada resultante, parcialmente, pelo choque do petróleo de 1979, foram sentidos pela indústria da cana, demonstrado pela perda de momento que havia se iniciado com o PROÁLCOOL levando a perda de significância do Brasil na produção mundial de cana. A solução para a perda de momento da indústria canavieira veio com a extinção do sistema de cotas de produção com o fim do $\mathrm{IAA}^{35}$. A relevância da produção brasileira também repercute nos patamares de preços do mercado internacional, sendo que flutuações na oferta brasileira de cana a cada ano safra tende a repercutir de forma direta sobre os preços do mercado internacionais, caracterizado por uma inelasticidade preço da demanda (SILVEIRA, 2004) o que resultou em momentos em que o aumento das quantidades produzidas e ofertadas teve como contrapartida um aumento proporcional nos valores recebidos pela exportação.

Em escala global, a tabela 2 mostra um cenário no qual a produção brasileira de açúcar bruto obteve ganho significante da parcela de mercado na década de 1970, na qual veio a superar a produção de Cuba, até então segunda maior produtora mundial. A tendência de crescimento continuou até superar, na década 1980 a União Soviética e se consolidar como maior produtor de açúcar do mundo.

35 Com o fim do sistema de cotas do IAA a indústria canavieira nordestina passou a realizar seus acordos de fornecimento de açúcar bruto diretamente com a entidades comerciais internacionais, isso gerarou a flexibilização dos preços e das quantidades fornecidas, algo daria impulso a economia canaveira em curtos prazo, mas que levaria a seu decaimento no longo prazo devido à concorrência com as demais regiões produtoras do país, 
Tabela 2. Produção mundial de Açúcar 1962 - 1982

\begin{tabular}{lrrrrr} 
Países Produtores & \multicolumn{5}{c}{ Produção (1000t) } \\
& \multicolumn{1}{c}{1962} & 1968 & 1972 & 1977 & 1982 \\
\hline Brasil & 3.354 & 4.275 & 6.350 & 8.500 & 9.420 \\
Índia & 3.086 & 2.357 & 3.437 & 5.239 & 9.100 \\
Cuba & 6.767 & 6.236 & 4.400 & 6.485 & 8.207 \\
União Soviética & 6.630 & 9.188 & 9.000 & 9.065 & 7.700 \\
Estados Unidos & 2.780 & 4.802 & 5.803 & 5.429 & 5.790 \\
França & 2.187 & 1.734 & 2.913 & 4.020 & 4.800 \\
China & 1.200 & 2.575 & 4.035 & 4.960 & 4.410 \\
Austrália & 1.371 & 2.440 & 2.801 & 3.300 & 3.560 \\
República Federal & 1.533 & 2.049 & 2.265 & 2.940 & 3.450 \\
México & 1.488 & 2.410 & 2.510 & 2.545 & 2.873 \\
\hline
\end{tabular}

Fonte: ANDRADE, 1988, p. 37

Ver o mercado pela ótica da produção de cana-de-açúcar é apenas ver uma das facetas da indústria do açúcar, para dar profundidade a análise das formas do mercado deve-se observar os fluxos de comercialização entre as nações no mercado mundial. Quanto às exportações de açúcar, a segunda metade do século XX, foi marcada por um crescimento instável os gráficos 2 a 7 traz as flutuações dos valores das exportações em milhares de dólares do ano 2000, cada gráfico remetendo às décadas de 1950,1960,1970,1980,1990 e 2000 .

Gráficos 2 a 7. Valores em milhares de dólares exportações brasileiras de açúcar bruto.

\section{1953 a 1959}

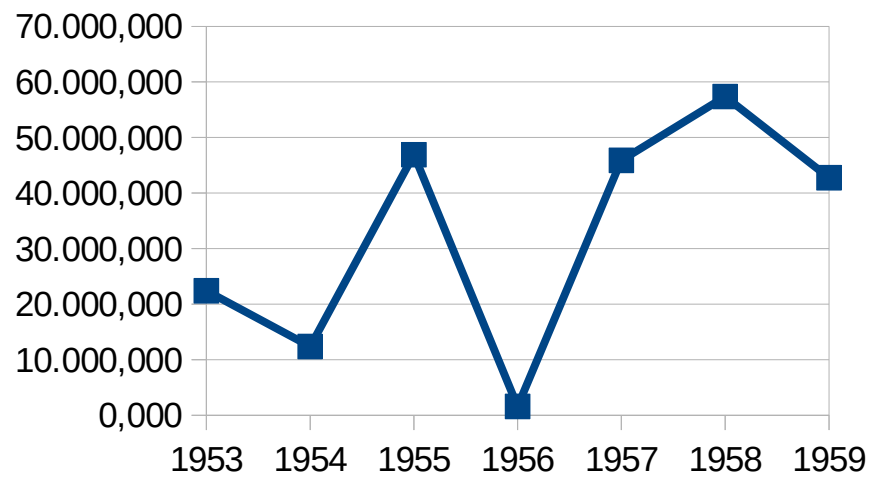

3. 1960 a 1969

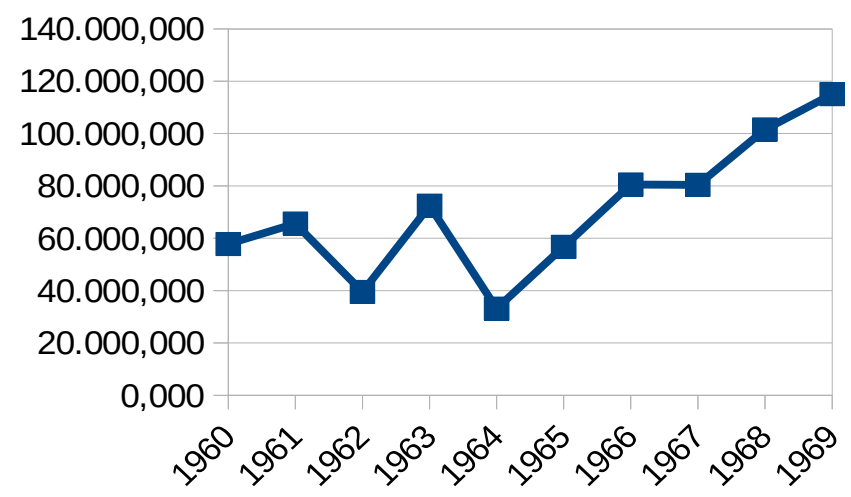


4. 1970 a 1979

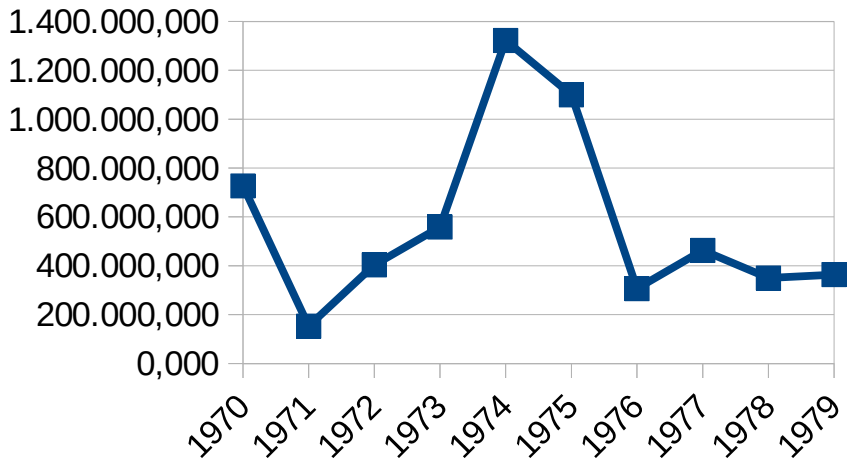

7.1990 a 1999

$2.500 .000,000$

2.000.000,000

1.500.000,000

1.000.000,000

$500.000,000$

0,000

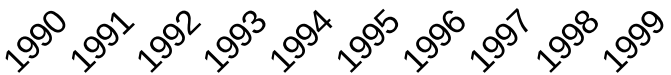

5.1980 a 1989

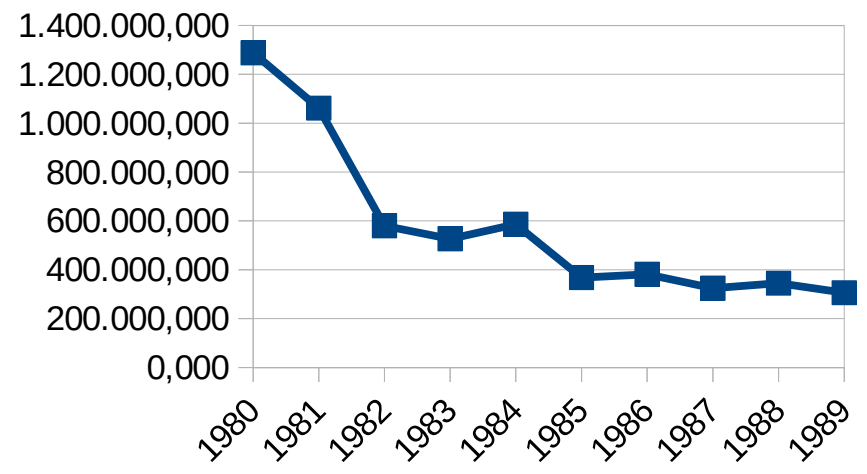

7. 2000 a 2009

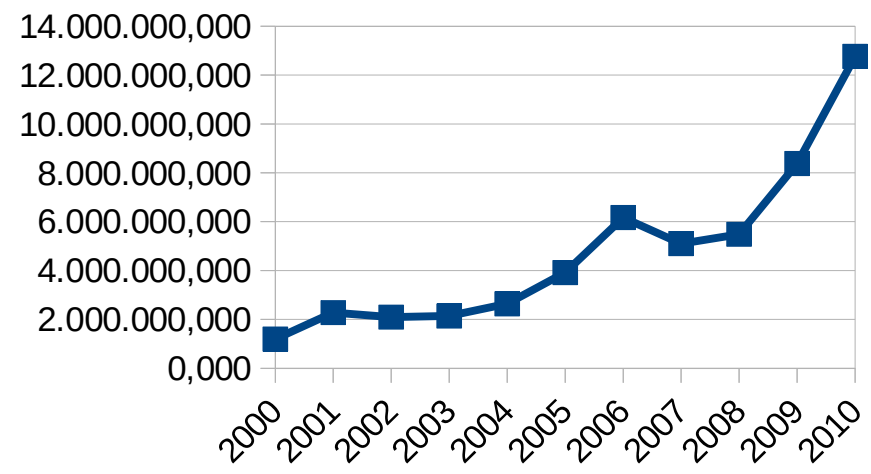

Fonte: IPEA

Os gráficos 2 a 7 evidenciam quatro momentos distintos:

I. Há um período de crescimento instável 1953 a 1973,

II. Seguido por um momento de crescimento constante de 1974 a 1983,

III. Nove anos com tendência de recessão, de 1983 a 1991

IV. Uma retomada ao crescimento constante, de 1992 a 2010

Quanto ao primeiro período, analisado temos um crescimento médio de $482 \%$ por ano. Tal se dá em decorrência da safra 1955\1956, na qual se deu a saída do Brasil do acordo internacional de cotas de fornecimento do açúcar, assinado com os países consumidores em 1953 (RAMOS, 2007). A volatilidade do período torna-se aparente ao considerar a mediana de recessão de $0,19 \%$. Isso indica vulnerabilidade do setor às mudanças nas negociações do regime de cotas de exportação da época, algo que só viria a se alterar com a criação do PROÁLCOOL e com o acordo de cotas de fornecimento de açúcar de 1979.

O segundo período, de 1974 a 1983, mostra um padrão de crescimento mais estável. Isso ocorreu devido a dois acontecimentos. O primeiro, associado à oferta de açúcar que havia, devido a um programa de medidas de modernização da indústria do açúcar implementado pelo IAA de 1961 a 1973 (RAMOS,2007). O choque do petróleo de 1973 foi 
um segundo acontecimento que potencializou os efeitos do primeiro, posto que o aumento do barril de petróleo aumentou a rentabilidade da produção de combustíveis substitutos, como o etanol.

Com o preço da gasolina em alta e uma capacidade produtiva ociosa foi possível inserir a cana-de-açúcar brasileira nos mercados de matéria-prima, com destino a produção de álcool combustível. Com isso, tornou-se possível manter a oferta internacional de açúcar a preços mais baixos que propiciou crescimentos estáveis no valor das exportações de açúcar com picos de altas nas exportações nos anos de 1974 e 1980, cujo os quais foram precedidos dos choques de do petróleo em 1973 e 1979.

Embora as altas repentinas nos preços dos barris de petróleo tenham beneficiado a indústria do açúcar no curto prazo, esta também viria a sentir os efeitos da crise generalizada que os choques desencadearam ${ }^{36}$. Já no final de 1981, as exportações de açúcar caíram 17,58\%, padrão de recessão que se consolidou pelo resto da década, tendo uma recessão mediana de 10,23\%, acompanhada por uma média de crescimento anual de 13,98\% inflada pelo ano de 1980 no qual as exportações ampliaram 254,10\% quando comparadas a 1979. Entretanto, tal expansão foi revertida em 1981 com queda de $16,80 \%$ de 1980 a 1981 e outra queda de 72,12\% entre os anos de 1981 a 1982.

O último período de análise das exportações foi caracterizado pela recuperação, com exceção dos anos de 1995 e 2007 . O valor das exportações de açúcar permaneceu em alta, ao ponto em que, em 1993, o Brasil se consolidaria, ultrapassando a Tailândia, como o país com o maior valor de exportações de açúcar bruto do mundo. Para os anos de 2008/2009 temos que: "Os efeitos da crise econômica global de 2008/2009 foram suplantando pela severa seca que assolou regiões produtoras de açúcar na Índia, no ano de 2009.”(SOUZA, 2010 p.14) Com um dos principais competidores prejudicado por fatores climáticos, a indústria açucareira conseguiu manter o ritmo de crescimento de exportações, principalmente para o mercado russo, um dos principais consumidores do açúcar bruto indiano.

O crescimento médio na década de 1990 foi de 25,07\% ao ano, com crescimento mediano não muito distante de $18,10 \%$. O desempenho das exportações nos anos 2000 foi ainda melhor que na década de 1990 com crescimento médio de $24,67 \%$ e mediano de 23,37\%. A média aparentemente menor, em relação à década anterior foi suplantada com folga pelo desvio menor com relação a mediana.

36 O Efeito benéfico inicial se deu por uma redução na demanda por combustíveis derivados do petróleo, o que levou pelo efeito de substituição ao aumento da procura por combustíveis alternativos, aumentando com isso a procura pelo álcool combustível. 
Quanto à comercialização do açúcar refinado ou centrifugado. O volume total de exportações de açúcar refinado possui alguns principais produtores distintos no mercado de açúcar bruto, com destaque para os países desenvolvidos europeus e norte-americanos, com exceção da Tailândia que vem tendo desempenho significativo desde meados da década de 2000. A tabela 3 expõe os valores totais de açúcar bruto e refinado exportados no mundo, em milhões de dólares estados unidenses(US\$), com periodicidade anual de 1995 a 2015.

Tabela 3.Volume de Exportações Mundiais de Açúcar Bruto e Refinado - Unidade = milhões de US\$ do ano 2000

\begin{tabular}{ccc}
\hline \multicolumn{3}{c}{ Exportação de açúcar } \\
Ano & Valor do & $\begin{array}{c}\text { Valor do } \\
\text { Açúcar } \\
\text { refinado }\end{array}$ \\
\hline 2015 & 23.700 & 325 \\
2014 & 28.700 & 418 \\
2013 & 33.300 & 456 \\
2012 & 36.100 & 447 \\
2011 & 39.300 & 412 \\
2010 & 32.000 & 531 \\
2009 & 23.100 & 340 \\
2008 & 20.700 & 434 \\
2007 & 18.900 & 389 \\
2006 & 20.800 & 485 \\
2005 & 15.700 & 268 \\
2004 & 11.900 & 163 \\
2003 & 11.100 & 207 \\
2002 & 10.400 & 166 \\
2001 & 10.700 & 136 \\
2000 & 8.860 & 112 \\
1999 & 9.570 & 73,6 \\
1998 & 11.000 & 76 \\
1997 & 11.800 & 59,3 \\
1996 & 12.400 & 99,3 \\
1995 & 10.900 & 65,7 \\
\hline
\end{tabular}

Fonte: atlas.media.mit.edu

A comercialização do açúcar no mercado internacional é realizada em sua maior parte com açúcar bruto, representando, em média, 98,66\% do total de exportações no período observado. Já os valores do açúcar refinado reapresentaram somente 1,34\%. Pode-se observar, no entanto, um aumento da representação do açúcar refinado, que apresentou uma taxa média de crescimento de 13,21\%, na qual os valores de exportações de açúcar bruto cresceram 5,21\%. Embora a grande predominância seja do açúcar bruto, o açúcar refinado vem ganhando espaço no comércio internacional desde meados dos anos 2000.

Quanto aos principais países exportadores de açúcar refinado, temos maior participação dos países desenvolvidos, EUA e Alemanha são as duas nações com maior 
desempenho no mundo, seguidos com ampla margem pela Tailândia, que é o único país com significativa expressão nas ofertas internacionais de açúcar bruto e refinado.

A tabela 4 traz os valores das exportações dos três países com maior representação na oferta mundial de açúcar refinado em dólares americanos no período de 1995 a 2015.

Tabela 4. Valor das exportações de açúcar refinado dos três maiores exportadores do Mundo 1995-2015

\begin{tabular}{ccccccc}
\hline \multicolumn{5}{c}{ Exportações de Açúcar Refinado(US\$) } \\
Data & EUA & Var(\%) & Alemanha & Var(\%) & Tailândia & Var(\%) \\
\hline 2016 & 31.858 .552 & 0 & 17.155 .883 & 0 & 13.634 .385 & -1 \\
2015 & 40.145 .040 & 0 & 22.148 .797 & 0 & 28.690 .034 & 0 \\
2014 & 31.164 .516 & 0 & 25.535 .302 & 0 & 33.445 .552 & 0 \\
2013 & 32.170 .101 & 0 & 19.178 .215 & 0 & 24.453 .339 & 0 \\
2012 & 32.300 .426 & 0 & 18.924 .991 & 0 & 37.280 .795 & 1 \\
2011 & 37.925 .440 & 1 & 15.849 .583 & 0 & 16.331 .827 & 3 \\
2010 & 17.377 .972 & 0 & 16.862 .162 & 0 & 4.438 .837 & 0 \\
2009 & 13.990 .370 & 0 & 16.272 .000 & 0 & 7.071 .446 & 0 \\
2008 & 26.373 .335 & -1 & 17.256 .000 & 0 & 7.252 .333 & 0 \\
2007 & 67.007 .880 & 0 & 15.376 .000 & 0 & 14.257 .856 & 0 \\
2006 & 54.941 .203 & 1 & 13.023 .000 & 0 & 9.740 .220 & 4 \\
2005 & 33.230 .925 & 1 & 11.355 .000 & 0 & 1.970 .010 & 18 \\
2004 & 16.771 .121 & 1 & 11.363 .000 & 0 & 105.256 & 2 \\
2003 & 10.804 .153 & 0 & 9.165 .000 & 0 & 40.180 & 1 \\
2002 & 10.508 .008 & 0 & 7.476 .000 & 0 & 23.558 & -1 \\
2001 & 11.666 .038 & 1 & 6.523 .000 & 0 & 68.112 & -1 \\
2000 & 6.216 .248 & 0 & 5.205 .000 & 0 & 190.631 & 4 \\
1999 & 5.394 .693 & 0 & 4.294 .656 & 0 & 40.119 & 1 \\
1998 & 4.821 .105 & 0 & 4.186 .000 & 0 & 26.467 & 1 \\
1997 & 6.015 .373 & 0 & 2.985 .104 & 0 & 11.352 & 0 \\
1996 & 5.123 .223 & 0 & 2.750 .223 & 0 & 8.375 & 0 \\
1995 & 5.281 .754 & 0 & 3.316 .000 & 0 & 5.608 & 0 \\
1994 & 5.417 .756 & 1 & 2.334 .000 & 0 & 8.344 & 4 \\
1993 & 2.331 .601 & 1 & 2.338 .000 & 1 & 1.743 & 3 \\
1992 & 1.352 .489 & 0 & 1.423 .000 & 0 & 469 & -1 \\
1991 & 1.788 .476 & - & 1.373 .000 & - & 23.303 & - \\
\hline
\end{tabular}

Fonte: $\underline{w w w . f a c t f i s h . c o m}$

No período observado, os Estados Unidos da América perderam espaço no mercado, com um crescimento mediano de 11,90\%, comparativamente menor que a Alemanha, com 12,23\%, e a Tailândia, com 46,38\%. Esse último teve desempenho significativo, saindo de uma média de 12.809,62 US\$ na década de 1990 para 4.079.960,20 US\$, na década seguinte.

O Brasil, com sua forte influência no mercado de açúcar bruto, teve, em 1995, representação de $1,79 \%$ do total de exportações, perdendo significância nos primeiros 15 anos do século XXI chegando em 2015 a representar somente 0,14\% do valor total de açúcar refinado exportado no mundo.

Nas interpretações de Manoel Correia de Andrade em obras como "A Terra e o Homem no Nordeste", "Área do Sistema Canavieiro", "Nordeste, Espaço e Tempo", dentre 
outras, possui um foco de fora da região para dentro, isso significa que as análises de elaboradas pelo autor são voltadas a descrição e estudo das ramificações de mudanças externas dentro do sistema canavieiro Nordestino, assim como na maneira com que esses efeitos exógenos influem nas formas com as quais é empregada a mão de obra do homem Nordestino, a que passo é explorado o meio ambiente e as tendências de mudanças na utilização das terras. Uma citação que resume bem a posição de Andrade quanto ao mercado externo é encontrada em "A Terra e o Homem no Nordeste", no capítulo 8, sobre os impactos da Globalização, sendo essa:

“A Globalização é a terceira etapa do desenvolvimento do capitalismo, que se segue ao colonialismo e ao imperialismo; ela foi intensificada a partir de 1989, com a queda do muro de Berlim e a dissolução da União Soviética. Destruído o "socialismo real" como sistema econômico-social e político, sob a égide de uma grande potência, puderam os grandes grupos econômicos dos países ricos planejar a exploração dos recursos do mundo, em escala planetária, e impor uma unidade que abrange toda a superfície do planeta; as fronteiras entre os estados, nos vários continentes, passaram a ser explorados em função de capitais financeiros de grande e rápida mobilidade. Com a globalização, organizou-se o neoliberalismo que destruiu ou está destruindo o poder dos sindicatos, enfraquecendo as organizações sociais e eliminando os direitos do homem. Ao mesmo tempo, para maximizar os lucros, está procedendo à destruição da natureza, levando o mundo a uma catástrofe como a que se vem observando através dos estudos sobre o meio ambiente.”(ANDRADE, 2010, p. 258)

Observa-se na citação acima o posicionamento de Andrade quanto ao desenrolar de um acontecimento externo à região do Nordeste, e evidentemente externo ao Brasil, cujas ramificações mudaram os rumos das atividades da região, influindo sobre os espaços do Nordeste, quando menciona a proposta unificação do mercado mundial. O impacto sobre as organizações do trabalho, com a perda de representação dos sindicatos e sobre as futuras repercussões da devastação do meio ambiente. Nesse parágrafo, Andrade lança seu posicionamento sobre os três principais eixos de sua obra literária, a saber, o espaço, o homem e a terra. 


\section{O Mercado De Álcool Combustível: O Etanol como Meio Energético Alternativo}

No setor sucroalcooleiro, desde a década de 1930, se produziu paralelamente ao açúcar o álcool combustível, um produto cuja demanda ampliou em momentos de crise internacional, seja no final da década de 1930 e começo da 1940 devido a segunda guerra mundial ou aos choques de alta dos preços do barril do petróleo na década de 1970 (ANDRADE, 1988). Tais acontecimentos levaram o Brasil, na segunda metade do século XX, a se tornar o país com maior volume de produção de álcool etanol do mundo, sendo superado somente pelos Estados Unidos da América no ano de 2004 quando a produção Brasileira atingiu o valor de 10.898.000 metros cúbicos, enquanto os Estados Unidos chegaram a produção de 12.885.536 metros cúbicos, com a ressalva de que o álcool etanol estadunidense tem como matéria-prima o milho transgênico, o qual desenvolveu-se com amplos aportes de capital e mesmo a participação ativa do Estado na década anterior, naquele país.

Andrade atribuiu a crescente importância do álcool combustível a investimentos governamentais voltados a quebrar a dependência do Brasil para com a gasolina. O Brasil da década de 1980 havia sofrido demasiadamente com os impactos das crises econômicas internacionais desencadeadas com os choques do petróleo. Como o Brasil era uma nação com forte dependência do consumo de gasolina estrangeira, as altas dos preços do barris de petróleo se transmitiram para diversos setores, senão todos, da economia. O Governo Federal, que já havia se defrontado com uma escassez de gasolina na época da Segunda Guerra (1939 1945), decidiu criar programas de incentivo à produção de álcool. Dentre eles, o mais impactante foi criado pelo Decreto 76.593, de 1975, que estabelecia o Programa Nacional do Álcool (PROÁLCOOL). Sobre as ações de tais programas, Andrade afirma:

“Observa-se ainda que no último decênio(1975-1985) houve um aumento espantoso da produção de açúcar e de álcool, provocado pelos programas modernizadores do Governo federal, com o uso em larga escala do capital acumulado pelo Fundo Especial de Exportações, que cresceu muito nos fins dos anos sessenta e nos primeiros anos da década de setenta, financiando, praticamente a juros negativos, a modernização e transferência de estabelecimentos industriais e a implantação de novas unidades de produção."(ANDRADE, 1988, p. 500) 
As consequências imediatas do PROÁLCOOL no Nordeste foram a modernização do maquinário de processamento e esmagamento da cana-de-açúcar, permitindo um aumento da produtividade das usinas, e da quantidade ofertada no mercado, sem que houvesse a disseminação das usinas e destilarias, que pouco variam nas quatro décadas entre 1980 a 2010, com a exceção do surgimento de plantas nos estados do Ceará, Bahia, Piauí e Maranhão e da redução do número de usinas no estado de Pernambuco.

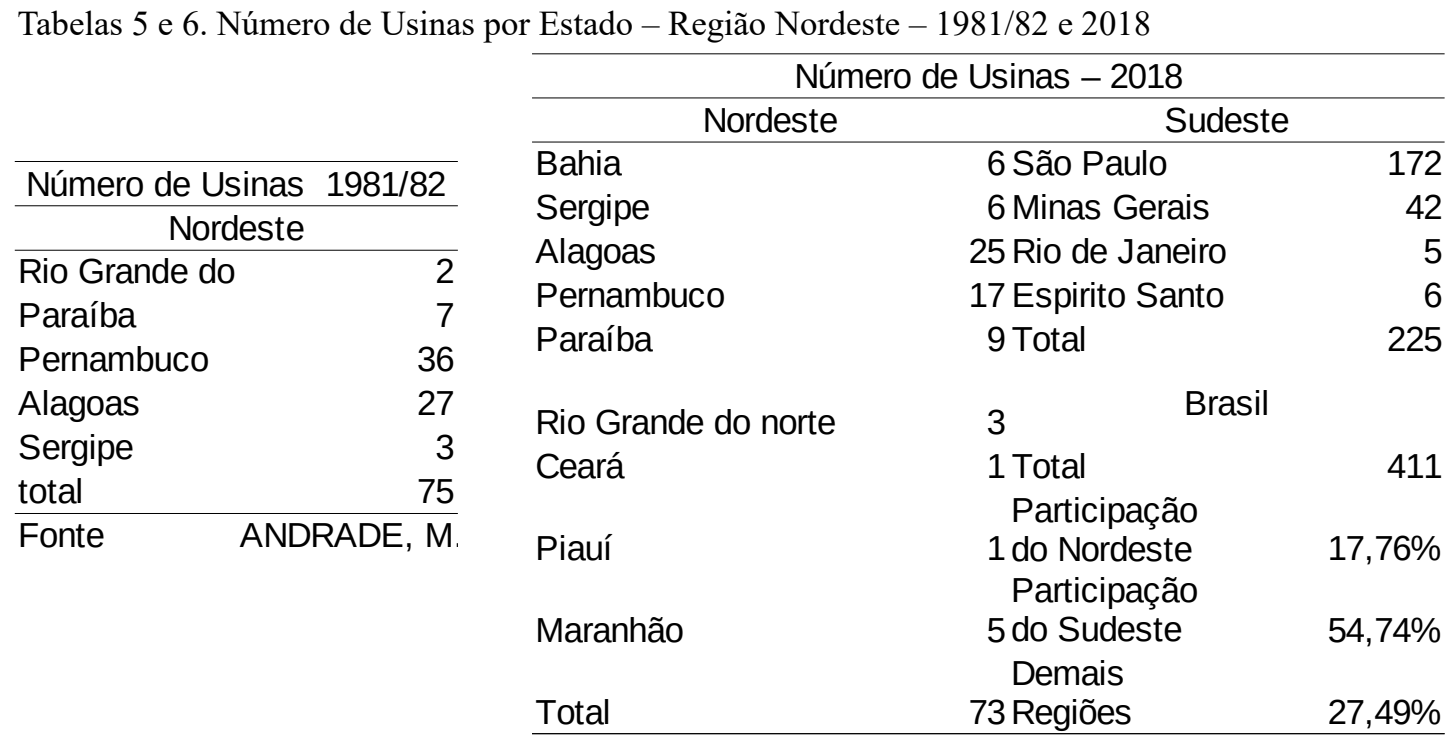

Fonte: Para 1981/82: ANDRADE, 1988, p. 501 Para 2018: www.novacana.com

Ao analisar-se as tabelas 5 e 6, é possível observar dois fenômenos na distribuição das usinas brasileiras nas regiões Nordeste e Sudeste. Primeiramente, o montante total de usinas no Nordeste não se alterou em valores absolutos, No entanto, o estado de Pernambuco, que na década de 1980 possuía o maior número de usinas, foi superado pelo estado de Alagoas.

Outro fenômeno diz respeito ao diferencial entre as regiões Nordeste e Sudeste, o Sudeste representa, em 2018, 54,74\% do total de usinas do Brasil. Já o Nordeste representa somente $17,76 \%$. Consideradas as extensões territoriais de ambas as regiões, o Sudeste tem uma distribuição espacial 5,19 vezes mais concentrada que o Nordeste.

Quanto aos volumes de álcool produzidos, com a busca de meios energéticos alternativos, e a queima dos combustíveis fosseis, houve nas últimas três décadas uma demanda crescente pelo etanol. Em contrapartida, houve crescimento acentuado da oferta em países desenvolvidos. Não somente os Estados Unidos da América tomaram a ponta na produção, mas países como o Canadá, a Alemanha e a França, dentre outros vêm investindo na capacidade de produção de álcool combustível, aumentado suas produções desde a última década. Isso posto, o mercado mundial de etanol continua concentrado, com o fluxo de 
exportações mundial sendo predominantemente do álcool Estados Unidense, com cerca de $49 \%$ das exportações, e do álcool brasileiro, com aproximadamente $26,5 \%$.

Tabela 7. Produção de Álcool Etanol - Principais Produtores - 1966 a 2015

\begin{tabular}{|c|c|c|c|c|c|}
\hline \multicolumn{6}{|c|}{ Principais Produtores de Etanol (Unidade $=$ Metros Cúbicos) } \\
\hline Ano\País & Estados Unidos da América & Brasil & China & Canada & Tailândia \\
\hline 2015 & 56.050 .566 & 23.496 .000 & 3.490 .000 & 1.357 .000 & 931.000 \\
\hline 2014 & 54.180 .573 & 21.945 .000 & 3.281 .000 & 1.396 .000 & 840.000 \\
\hline 2013 & 50.319 .455 & 21.076 .000 & 3.145 .000 & 1.346 .000 & 761.000 \\
\hline 2012 & 50.035 .549 & 17.870 .000 & 2.782 .000 & 1.361 .000 & 519.000 \\
\hline 2011 & 52.726 .976 & 17.522 .000 & 2.442 .000 & 1.310 .000 & 405.000 \\
\hline 2010 & 50.338 .382 & 21.524 .000 & 2.184 .000 & 1.093 .000 & 338.000 \\
\hline 2009 & 41.404 .815 & 19.832 .000 & 1.914 .000 & 1.025 .000 & 318.000 \\
\hline 2008 & 35.238 .382 & 20.564 .000 & 1.637 .000 & 647.000 & 256.000 \\
\hline 2007 & 24.684 .659 & 17.553 .000 & 1.336 .000 & 620.000 & 148.000 \\
\hline 2006 & 18.487 .942 & 13.311 .000 & 1.133 .000 & 203.000 & 100.000 \\
\hline 2005 & 14.778 .241 & 12.269 .000 & 1.009 .000 & 201.000 & 53.000 \\
\hline 2004 & 12.885 .536 & 10.898 .000 & 916.000 & 144.000 & 5.000 \\
\hline 2003 & 10.637 .002 & 10.827 .000 & 796.000 & 144.000 & - \\
\hline 2002 & 8.100 .777 & 9.312 .000 & 676.000 & 144.000 & - \\
\hline 2001 & 6.681 .249 & 8.095 .000 & - & 144.000 & - \\
\hline 2000 & 6.139 .935 & 7.558 .000 & - & 144.000 & - \\
\hline 1999 & 5.545 .626 & 9.435 .000 & - & 144.000 & - \\
\hline 1998 & 5.318 .501 & 10.372 .000 & - & 120.000 & - \\
\hline 1997 & 4.875 .608 & 11.605 .000 & - & - & - \\
\hline 1996 & 4.118 .526 & 10.447 .000 & - & - & - \\
\hline 1995 & 5.140 .587 & 9.293 .000 & - & - & - \\
\hline 1994 & 4.879 .393 & 9.226 .000 & - & - & - \\
\hline 1993 & 4.368 .363 & 8.455 .000 & - & - & - \\
\hline 1992 & 3.728 .629 & 8.914 .000 & - & - & - \\
\hline 1991 & 3.278 .165 & 9.812 .000 & - & - & - \\
\hline 1990 & 3.210 .028 & 8.527 .000 & - & - & - \\
\hline 1989 & 3.191 .101 & 11.809 .000 & - & - & - \\
\hline 1988 & 3.145 .676 & 11.523 .000 & - & - & - \\
\hline 1987 & 3.100 .251 & 12.340 .000 & - & - & - \\
\hline 1986 & 2.695 .212 & 9.983 .000 & - & - & - \\
\hline 1985 & 2.335 .598 & 11.563 .000 & - & - & - \\
\hline 1984 & 1.930 .559 & 9.201 .000 & - & - & - \\
\hline 1983 & 1.570 .945 & 7.951 .000 & - & - & - \\
\hline 1982 & 1.324 .894 & 4.240 .123 & - & - & - \\
\hline 1981 & 813.863 & 3.706 .375 & - & - & - \\
\hline 1980 & 662.447 & 3.396 .455 & - & - & - \\
\hline 1979 & - & 2.490 .603 & - & - & - \\
\hline 1978 & - & 1.470 .404 & - & - & - \\
\hline 1977 & - & 664.022 & - & - & - \\
\hline 1976 & - & 555.627 & - & - & - \\
\hline 1975 & - & 624.985 & - & - & - \\
\hline 1974 & - & 665.979 & - & - & - \\
\hline 1973 & - & 680.972 & - & - & - \\
\hline 1972 & - & 613.068 & - & - & - \\
\hline 1971 & - & 637.238 & - & - & - \\
\hline 1970 & - & 461.609 & - & - & - \\
\hline 1969 & - & 473.645 & - & - & - \\
\hline 1968 & - & 676.262 & - & - & - \\
\hline 1967 & - & 727.478 & - & - & - \\
\hline 1966 & - & 602.707 & - & - & - \\
\hline
\end{tabular}

Fonte: Dados dos EUA, China e Canada: www.factfish.com Dados para o Brasil: IPEA

Observando a tabela 7 , temos que a produção de etanol brasileira cresceu em média 18,12\% nos 15 anos de 1966 a 1980. Nesse período, os efeitos do PROÁLCOOL podem ser 
observados a partir de 1977, quando foi posto em funcionamento a capacidade ampliada de esmagamento da cana-de-açúcar.

Andrade seria o pioneiro ao apontar nas décadas de 1970 e 1980 os impactos que uma possível expansão das terras utilizadas na produção de matéria-prima para a indústria do álcool teriam sobre o meio ambiente ${ }^{37}$, levantando a questão de que um ritmo acelerado de crescimento, como observado nas décadas de 1970 e 1980 tenderia a desconsiderar os impactos sociais e ambientais que seriam processados na formação dos novos territórios econômicos expandidos (ANDRADE. 1979). Seria, então a voracidade da indústria capitalista de produção de álcool que condicionaria os fluxos migratórios do Nordeste brasileiro, na medida em que o maquinário moderno fosse instaurado e o capital humano se tornasse cada vez menos necessário. Quanto ao meio natural, Andrade já apontava que o objetivo de maximização dos lucros teria maior importância do que as necessidades de preservação do meio ambiente(ANDRADE, 1988).

A produção brasileira continuaria se expandindo durante a década de 1980 com alta em média de $17,58 \%$ ao ano, com a segunda metade da década caracterizada pela perda de momento da indústria que nos anos de 1986 e 1988 chegou a entrar em recessão. A década de 1990 consolidaria a tendência de freamento da indústria que em 1999 teria acumulado uma taxa média de recessão de 1,33\% ao ano, isso devido as políticas de abertura do mercado interno realizada pelos governos Neoliberais de Fernando Henrique Cardoso (FERREIRA, 2009) (1994 - 1998 e 1999 - 2002), que poriam o álcool brasileiro em maior grau de concorrência com o álcool estadunidense.

A recessão da indústria alcooleira somente terminaria com as políticas de incentivo à produção de carros bicombustíveis durante o Governo de Luiz Inácio Lula da Silva, (2003 2010). A maior demanda por álcool no mercado interno impulsionaria o mercado, permitindo a alocação da produção para o abastecimento interno e gerando um crescimento anual médio na produção de $8,57 \%$. Somente no ano de 2009 a produção acumularia um decréscimo como consequência do desencadeamento da crise econômica mundial de 2008. Entretanto, os efeitos recessivos da crise econômica mundial parecem ter sido de curto prazo, tendo a produção de álcool se recuperado na primeira metade da década de 2010 atingindo a modesta taxa de crescimento anual de $3,51 \%$.

37 Para mais informações buscar as obras: Nordeste, espaço e tempo(1970);Povoamento e degradação do meio de Natural(1975);A Problemática agropecuária de Pernambuco(1975); Agricultura e

Capitalismo(1979);Nordeste: a reforma agrária ainda é necessária?(1981);Área do sistema

canavieiro(1988) e O Nordeste e a questão regional(1988) 
Quanto ao caso dos Estados Unidos da América, a produção de Etanol de milho transgênico tem mostrado crescimentos constantes desde a década de 1980, tornando a potência ocidental a nação com maior produção e consumidora do mercado internacional. Maior consumidor não significa, nesse caso, maior importador: esse título é dado ao Canadá, de fato a maior parte do consumo estadunidense de etanol é suprido pela produção interna.

A política industrial dos Estados Unidos esteve sempre voltada ao protecionismo de suas atividades com maior grau de inovação interna. Isso seria um instrumento fundamental para os ganhos de market-share no mercado mundial de produção de combustíveis renováveis e considerados "limpos", quando comparados aos combustíveis fosseis. Tais políticas seriam de fato dividida em 3 grupos de ações: (I) Construir blocos de inovação na economia interna; (II) promover a concorrência de mercado para estimular o empreendedorismo produtivo e (III) estimular os avanços de acordo com as prioridades nacionais (MAFIOLETTI, 2011).

Os países em terceiro, quarto e quinto lugar no ranking de produção de etanol são a China, o Canadá e a Tailândia, respectivamente. Esses, no entanto, não possuem valores significativos, e se somados chegam em média a uma parcela de participação inferior a 8\% ao ano. O crescimento da produção internacional de etanol é fortemente influenciado pela produção dos Estados Unidos, que, desde meados dos anos 1990, tem-na liderado, consolidando as diretrizes do mercado, de maneira que essas são reproduzidas pelos países subdesenvolvidos da América Latina. T Nesse contexto, o Brasil tem apresentado crescimento correlato de sua produção, sem o mesmo impulso da demanda do mercado interno. Ou seja, com maior grau de dependência e vulnerabilidade externa à produção sucralcooleira.

\section{O Açúcar de Beterraba no Mercado Internacional.}

Paralelamente à comercialização do açúcar proveniente da cana-de-açúcar Brasileira se desenvolveu a cultivo da beterraba nos países europeus com intuito de suprir, mesmo que parcialmente a demanda de seus mercados internos. No século XX, a produção de beterraba se concentrou na União Soviética, na França e na Alemanha. Com a queda da URSS, a Rússia continuaria a exercer papel central na oferta de beterraba, sendo atualmente o maior país produtor da matéria-prima.

O segundo maior produtor de beterraba para a produção do açúcar são os Estados Unidos da América, que cultivam a beterraba na região da Flórida, de forma complementar à cana-de-açúcar para suprir sua demanda interna que, através de políticas intervencionistas 
empregas desde o governo de Bill Clinton (1993 - 2001) no começo da década de 1990, garantem um mercado preferencial à produção interna(LANGEVIN,2006).

Em terceiro lugar, encontra-se a França, onde a indústria do açúcar se encontra dividida entre as usinas de açúcar de beterraba na Europa e as refinarias e usinas de cana-deaçúcar localizadas na região de ultramar formada pela Guiana Francesa na América do Sul, Guadalupe e Martinica na região Caribenha e Mayotte e Reunião no oceano índico.

Tabela 8. Produção de Beterraba - Toneladas - 1992 a 2016

\begin{tabular}{|c|c|c|c|c|c|}
\hline \multicolumn{6}{|c|}{ Produção de Beterraba } \\
\hline Ano & Rússia & EUA & França & Alemanha & Mundo \\
\hline 2016 & 51.366 .830 & 33.457 .880 & 33.794 .906 & 25.497 .200 & 277.230 .790 \\
\hline 2015 & 39.030 .505 & 32.088 .030 & 33.507 .670 & 22.572 .000 & 244.731 .824 \\
\hline 2014 & 33.513 .369 & 28.381 .270 & 37.844 .567 & 29.748 .100 & 270.252 .518 \\
\hline 2013 & 39.321 .161 & 29.745 .680 & 33.630 .536 & 22.828 .700 & 247.680 .490 \\
\hline 2012 & 45.056 .852 & 31.954 .680 & 33.077 .399 & 27.686 .800 & 269.539 .263 \\
\hline 2011 & 47.643 .272 & 26.214 .040 & 37.944 .864 & 29.577 .500 & 278.726 .573 \\
\hline 2010 & 22.255 .939 & 29.060 .756 & 31.874 .920 & 23.431 .929 & 228.306 .986 \\
\hline 2009 & 24.892 .024 & 27.018 .680 & 35.160 .333 & 25.919 .041 & 227.925 .780 \\
\hline 2008 & 28.995 .280 & 24.386 .030 & 30.321 .172 & 23.002 .600 & 221.119 .239 \\
\hline 2007 & 28.836 .189 & 31.912 .000 & 33.229 .782 & 25.139 .137 & 246.894 .685 \\
\hline 2006 & 30.672 .874 & 34.064 .000 & 29.871 .449 & 20.646 .600 & 253.949 .575 \\
\hline 2005 & 21.275 .534 & 27.433 .000 & 31.149 .552 & 25.284 .700 & 253.737 .449 \\
\hline 2004 & 21.809 .390 & 30.021 .000 & 30.788 .266 & 27.158 .966 & 251.589 .379 \\
\hline 2003 & 19.355 .316 & 30.710 .000 & 29.329 .541 & 23.715 .735 & 232.734 .275 \\
\hline 2002 & 15.658 .832 & 27.707 .000 & 33.463 .755 & 26.794 .334 & 259.607 .018 \\
\hline 2001 & 14.552 .677 & 25.708 .000 & 26.847 .121 & 24.729 .921 & 230.315 .030 \\
\hline 2000 & 14.050 .869 & 32.541 .000 & 31.120 .959 & 27.870 .100 & 250.148 .599 \\
\hline 1999 & 15.225 .912 & 30.318 .000 & 32.473 .614 & 27.568 .807 & 260.565 .507 \\
\hline 1998 & 10.796 .182 & 29.483 .000 & 30.789 .880 & 26.787 .164 & 263.030 .081 \\
\hline 1997 & 13.878 .828 & 27.112 .000 & 34.005 .439 & 25.768 .883 & 267.970 .311 \\
\hline 1996 & 16.165 .349 & 24.204 .000 & 30.921 .147 & 26.064 .135 & 264.461 .322 \\
\hline 1995 & 19.071 .562 & 25.460 .000 & 30.342 .117 & 26.048 .756 & 264.504 .932 \\
\hline 1994 & 13.945 .541 & 28.897 .000 & 28.898 .195 & 24.211 .265 & 254.453 .778 \\
\hline 1993 & 25.467 .912 & 23.812 .200 & 31.619 .824 & 28.605 .780 & 282.190 .566 \\
\hline 1992 & 25.547 .700 & 26.438 .000 & 31.534 .288 & 27.149 .872 & 281.711 .742 \\
\hline
\end{tabular}

Fonte:www.factfish.com

Com a Tabela 8 pode-se notar que no caso da beterraba, diferentemente da cana, a produção mundial se encontra proporcionalmente mais distribuída entre os maiores produtores. Para a década de 1990, observa-se uma participação média de aproximadamente $10 \%$ do total produzido no mundo para os três maiores produtores, estando a Rússia em quarto lugar com uma média de representatividade de 6,5\%. Para a década de 2000, o mercado mundial de beterraba continua competitivo, com a Rússia ganhando participação na produção mundial, chegando a representar 10,92\% da produção total. É somente a partir do ano de 2011 que a produção russa supera a França os Estados Unidos e a Alemanha, representando $17,09 \%$ da produção mundial. 
A beterraba em meados do século XX concorreu com a cana-de-açúcar e com o milho para ganhar a função de matéria-prima na produção tanto do açúcar e, em menor escala, na produção de álcool combustível. Entretanto, a partir da década de 1990 fica evidente que essa seria a alternativa com menor representação, sendo a maior parte do comércio internacional de açúcar baseado na produção do açúcar da cana.

Tabela 9. Valores das Exportações de Açúcar de Cana e de Beterraba - 1989 a 2015

\begin{tabular}{ccc}
\hline \multicolumn{3}{c}{ Exportações de Açúcar Bruto (Unidade de US\$) } \\
Exportação - & $\begin{array}{c}\text { Exportação - Reino Unido } \\
\text { Brasil - Açúcar de } \\
\text { cana }\end{array}$ & $\begin{array}{c}\text { Exparcar de Beterraba } \\
\text { - Açu }\end{array}$ \\
\hline 1989 & 306.198 .000 & - \\
1990 & 525.860 .000 & - \\
1991 & 398.087 .000 & - \\
1992 & 599.421 .000 & - \\
1993 & 786.675 .000 & 3.172 .581 \\
1994 & 992.205 .000 & 922.854 \\
1995 & 1.919 .460 .000 & 6.030 .366 \\
1996 & 1.611 .494 .000 & 4.280 .246 \\
1997 & 1.773 .984 .000 & 4.618 .988 \\
1998 & 1.943 .433 .650 & 1.487 .227 \\
1999 & 1.910 .692 .617 & 11.612 .438 \\
2000 & 1.199 .110 .875 & 9.161 .829 \\
2001 & 2.279 .059 .664 & 11.562 .406 \\
2002 & 2.093 .643 .745 & 10.316 .487 \\
2003 & 2.140 .022 .403 & 14.146 .425 \\
2004 & 2.640 .229 .042 & 13.195 .130 \\
2005 & 3.918 .849 .770 & 11.831 .321 \\
2006 & 6.167 .015 .107 & 37.565 .415 \\
2007 & 5.100 .530 .281 & 107.077 .688 \\
2008 & 5.483 .037 .064 & 81.402 .057 \\
2009 & 8.377 .828 .131 & 87.738 .521 \\
2010 & 12.761 .731 .496 & 47.073 .772 \\
2011 & 11.548 .785 .770 & 36.625 .999 \\
2012 & 9.836 .040 .529 & 80.505 .039 \\
2013 & 9.163 .695 .920 & 64.312 .213 \\
2014 & 7.450 .078 .297 & 90.091 .206 \\
2015 & 5.901 .103 .830 & 94.232 .038 \\
\hline
\end{tabular}

Fonte:www.factfish.com

Comparando então as exportações do açúcar de beterraba e cana-de-açúcar tem-se um cenário com duas ofertas diferente que suprem a mesma procura sendo o açúcar de cana predominantemente utilizado nas transações do mercado mundial, é importante pontuar, no entanto que, em mercados como o francês e o alemão, as políticas protecionistas impedem uma entrada significativa do açúcar de cana, garantindo assim o mercado para a beterraba.

É sob as formas dos mercados internacionais acima caracterizados de se deve considerar as interpretações de Manoel Correia de Andrade, tendo em vista que o cientista buscou desenvolver estudos sobre as formas das organizações da sociedade e da economia nordestinas tendo o mercado internacional como fonte de choques externos. Para Andrade, a natureza das mudanças externas parece ser de menor significância quando posta em 
comparação com as formas em que tais mudanças são processadas pela economia e sociedade brasileira e consequentemente, pela nordestina.

\section{Um Mercado Interno Polarizado: a Dinâmica Centro-sul $\mid$ Nordeste}

A produção de cana-de-açúcar no Brasil ocorre em dois polígonos, um localizado na região Nordeste, se estendendo do sudeste baiano até o município de Touros, ao norte potiguar. Já o segundo polígono encontra-se tem seu centro no estado de São Paulo estendendo-se pelo sudeste e centro-oeste, incluindo, ainda, ao sul, uma parte significativa do estado do Paraná, limitando-se a uma zona de transição com a pecuária nos municípios de Laranjal e Palmital. Isso não significa dizer de forma alguma que a produção de cana seja exclusiva a esses polígonos. De fato, no Brasil, atualmente, se produz cana em praticamente todos os estados, sendo os polígonos mencionados os centros com maior representação.

A cana-de-açúcar cultivada nos latifúndios do Nordeste formam no litoral nordestino uma faixa continua e uniforme que nas colinas originárias da Mata Atlântica, hoje só se encontra um "mar" de cana que se estende, em certos locais, de horizonte a horizonte com pequenos estabelecimentos dispersos voltados à produção de culturas de subsistência, cuja produção tem como objetivo alimentar uma população que sazonalmente se emprega na colheita da cana, e que o resto do ano se encontra marginalizada dentro do território dos latifúndios canavieiros. Essa forma de organização social no campo, segundo Andrade, seria a mais nova adaptação do Nordeste a uma:

"Expansão do processo capitalista no campo é representado na paisagem pelo domínio da monocultura - são quilômetros e quilômetros sem se ver outra planta que não seja a cana-de-açúcar ; com uma série de consequência bem previsíveis. O que se vê é a grande distância econômica entre o proprietário de terras e de máquinas ou o proprietário apenas de terras, de um lado, e aqueles que dispõem apenas da sua força de trabalho, do outro. Para que as empresas tenham sempre mais lucros e possam expandir a sua produção para competir com as concorrentes, faz-se o desenvolvimento da técnica industrial, sem levar em conta as consequências sociais e ecológicas deste desenvolvimento. (ANDRADE, 1988, p.545) 
Andrade atribui a transição acelerada para um modelo capitalista o domínio do território de cana-de-açúcar. A consolidação dos poderes dos latifundiários em seus territórios é feita pelo controle dos cargos públicos locais, que são os pontos extremos de uma cadeia de poder político que se amplia até os níveis estaduais de maneira que poder políticos locais para garantirem a sua continua existência se aliam para controlar cargos centrais nas administrações dos estados(ANDRADE, 2000).

Andrade, em sua obra "A Terra e o Homem no Nordeste" buscou descrever a propriedade e a mão de obra na zona da mata e no litoral ocidental, as formas com que se organizaram as sociedades e economias nordestinas perante o meio em que estão inseridas. A busca constante de Andrade em sua forma descritiva sempre tende a passar pelo ponto central que é a presença humana no Nordeste, seja essa social ou econômica. Assim, o autor descreveu as formas de trabalho atuais numa dinâmica na qual:

"Os trabalhadores assalariados também denominados em certas áreas, "Trabalhadores de eito", "cassacos" e "eiteiros" constituem a imensa maioria dos trabalhadores rurais na área açucareira. Conforme a sua fixação à terra e dependência ao proprietário, podem ser agrupados em três categorias: os moradores que residem na propriedade onde trabalham; os trabalhadores "de fora", que vivem nas cidades, vilas e povoações da zona, constituindo a maioria da população das mesmas; e os "corumbas" ou "caatingueiros" que residem no Agreste e Sertão, mas que se deslocam todos os anos para a zona canavieira durante a safra, a fim de participar da colheita. Fazem, assim, uma migração sazonal, uma vez que com as primeiras chuvas voltam para sua terra.”(ANDRADE, 2011, p. 127)

Esse contingente de trabalhadores assalariados que sazonalmente migram para encontrar empregos que lhes deem a capacidade de sustento são uma herança das lutas campesinas que aconteceram no século XX, nas quais o processo de modernização do sistema açucareiro teria como consequência o fim dos estabelecimentos rurais campesinos persistindo em paralelo aos latifúndios capitalistas (ANDRADE,2000)

Na tese de doutoramento "Modernização, Relações de Trabalho e Poder. Um estudo das transformações recentes na agroindústria canavieira do Nordeste" do José Roberto Pereira Novaes encontra-se uma discrição similar do mercado de trabalho. Segundo Novaes: 
"Dessa época do ano (entressafra), a oferta de emprego na lavoura canavieira é bastante limitada, principalmente se comparada à da época da safra. A mão de obra para o trabalho no canavial é recrutada geralmente no interior das propriedades, entre os moradores (1) e na periferia das cidades localizadas na própria zona canavieira. Durante o inverno, praticamente não são recrutados trabalhadores do agreste e do sertão, por estarem envolvidos com o trabalho agrícola na própria região onde vivem. ou por se encontrarem trabalhando em outros setores, em outras regiões, muitos dos quais nas safras de cana na região Centro/Sul e Centro/Oeste.”(NOVAES, 1993. p. 138).

Há outros trabalhos que evidenciam as tendências da cultura canavieira em gerar mercados de trabalho temporários que causam uma intensificação nos movimentos migratórios, fazendo com que um contingente de mão de obra fique subutilizado nos momentos de entressafra e sobreutilizado nas colheitas (WANDERLEY, 1979,SILVA, 1999, PLANCHEREL, 2007).

Cabe pontuar que a interpretação de Andrade se alterou e se consolidou ao decorrer da segunda parte do século XX. De fato, Andrade, em sua obra "Os Rios-Do-Açúcar Do Nordeste Oriental" (1959), tinha uma visão muito mais otimista quanto ao papel modernizante organizador do surgimento das usinas, acreditando que a "velha agricultura extensiva e de baixos rendimentos vai sendo substituída pela agricultura intensiva com rendimentos compensadores.”(ANDRADE, 2010, p. 68).Tal crença, no entanto, viria a se transformar, de maneira que na última edição de "A Terra e o Homem no Nordeste" Andrade dedicaria um capítulo sobre as evoluções da agricultura moderna, e os efeitos nocivos que o novo modelo econômico traria à sociedade e ao meio ambiente.

Toda a produção de cana-de-açúcar, seja no pólo Nordeste ou no pólo SudestelCentrooeste, é dedicada a produção de açúcar e álcool combustível, sendo dividida segundo Tirches de maneira que:

“ Destaca-se também que a matéria-prima utilizada para produção de açúcar é feita exclusivamente a partir da cana-de-açúcar. A vantagem é que a essa matéria-prima pode ser processada tanto para a fabricação de açúcar como para álcool. Atualmente, a cana-de-açúcar é destinada 
para cada um dos produtos em proporções relativamente equivalentes.”(TIRCHES, 2009, p.5)

Essas formas de produção são um ponto de similaridade entre os pólos. As produções dos municípios adjacentes transportadas pro vias rodoviárias e férreas para as usinas e destilarias criariam o uma complexa rede de abastecimento, com as usinas em foco central. Exemplos de tais redes se encontram no estado de São Paulo, maior produtor de açúcar do país, representando, aproximadamente, nas décadas de 1970, 1980 e 1990, 44\%, 53\% e 59\% do total produzido no país. A tabela 10 traz a produção de cana-de-açúcar do Brasil e do estado de São Paulo em toneladas de 1970 a 2010.

Tabela 10. Produção de Cana-de-Açúcar 1970 -2010, em toneladas

\begin{tabular}{rrrr}
\hline \multirow{2}{*}{ Ano } & \multicolumn{3}{c}{ Produção de Cana-de-Açúcar(toneladas) } \\
& São Paulo & Participação (\%) & Brasil \\
\hline 1970 & 30357197 & $38,06 \%$ & 79752936 \\
1975 & 38321281 & $39,71 \%$ & 96503827 \\
1980 & 76303032 & $49,54 \%$ & 154016896 \\
1985 & 128990668 & $50,90 \%$ & 253398672 \\
1990 & 137835000 & $52,47 \%$ & 262674150 \\
1995 & 174960000 & $57,61 \%$ & 303699497 \\
2000 & 189040000 & $57,97 \%$ & 326121011 \\
2005 & 254809756 & $60,24 \%$ & 422957366 \\
2010 & 426056499 & $59,41 \%$ & 717148531 \\
\hline
\end{tabular}

Fonte:IBGE

Quanto à participação de São Paulo no total de cana-de-açúcar produzida no Brasil, a tabela 9 revela que o estado, desde 1970, possui parcela significativa, ganhando cada vez mais importância no mercado doméstico. Tal avanço da participação de São Paulo ocorreu devido à incapacidade das usinas pernambucanas de competir em um mercado com tendências gerais de queda de preços, fazendo com que a rentabilidade da atividade ficasse vinculada a capacidade de aumento da escala de produção através do aumento da produtividade. $\mathrm{O}$ sistema açucareiro de Pernambuco perdeu então representatividade no mercado do açúcar, sendo que, no mesmo período da tabela 9 , o estado passou de um volume de 13,69\% para apenas $2,71 \%$ da produção nacional.

\section{As Outras Culturas do Domínio da Terra}

A cana domina o território, e por consequência o uso das terras do litoral e da Zona da Mata nordestinas. No entanto, essas regiões são de pequena expressão no tocante de extensão geográfica, fincando atrás somente do Agreste. A maior parte do Nordeste esta inserida na 
zona caracterizada pelo Polígono das Secas, o Sertão, região onde predomina a caatinga, onde as estações são duas, a das chuvas e a da seca, que assola a população pelo despreparo intencional dos grupos dominantes. Seguindo, ainda mais a leste encontra-se, para além do polígono das secas, o cerrado maranhense e o litoral setentrional, região que, agregada ao leste do Piauí, compõe o Meio-Norte.

Nas terras para além do espaço econômico da cana-de-açúcar, se encontram atividades voltadas à agricultura de subsistência, criação de gado de corte e leiteiro e culturas cujo principal objetivo é a manutenção da estrutura fundiária.

A leste da Zona da Mata e do litoral encontra-se a região do semiárido nordestino compostas do Sertão e da parte leste do Agreste, englobando uma área de 982.563,3 Km², caracterizada pela vegetação da caatinga, solo cristalino de difícil utilização para a agricultura, e escassez de recursos hídricos(IBGE). Nessa região, as cidades, vilas e povoados ficam aglomerados aos redores dos rios temporários, que só correm nos breves períodos de chuvas, com exceção das cidades situadas à beira do rio São Francisco, que pelas suas propriedades hidrológicas, corre o ano todo.

A região do Agreste situada na Borborema é considerada por Andrade como uma zona de transição entre a Zona da Mata e o Sertão. É caracterizada pela maior diversidade de atividades agrícolas e pela maior presença de estabelecimentos de pequeno e médio porte (ANDRADE, 2010). Nessa região, podemos encontrar a produção de fumo, gado leiteiro, culturas de tubérculos como a mandioca, inhame, cará e batata em Pernambuco, Alagoas. Na Paraíba pode-se encontrar pequenos estabelecimentos, que reproduzem em escala reduzida a produção da cana-de-açúcar copiando os modelos da Zona da Mata ${ }^{38}$.

No Agreste ainda há atividades que são reflexivas do seu período de desbravamento, onde a pecuária tinha um papel fundamental como subsidiária dos estabelecimentos da cana no litoral. Assim, o gado criado para servir de força motriz nos engenhos era criado nas zonas periféricas ao cultivo da cana. Por esse motivo, se estabeleceram as primeiras fazendas criadoras de gado bovino no Agreste (ANDRADE, 2010). O Agreste seria então um espaço econômico sob a égide do território do sistema primário exportador de açúcar para a metrópole portuguesa, tendo papel de atividade suplementar à da cana.

A região passou, após o período colonial, a ser a fronteira onde se chocam os territórios do gado sertanejo e a cana da Zona da Mata, sendo que em momentos de alta na

38 Exemplos de tais estabelecimentos podem ser encontrados nos municípios de Caruaru em Pernambuco, Areias na Paraíba e Quebrangulo em Alagoas. 
rentabilidade da cana-de-açúcar, a produção de gado se desloca para regiões mais próximas do Sertão. O contrário não pode ser dito aos momentos de alta dos preços da carne e do leite, que tendem a deslocar-se no sentido leste-oeste com menor intensidade. Dessa forma, no Agreste, pode-se se localizar o centro de criação de gado elástico a mudanças nos preços e rentabilidade da cana-de-açúcar e o centro de produção de cana inelástico a alterações nos preços e rentabilidade da produção proveniente do sistema de criação do gado.

Os ciclos de produção primário-exportadora do Brasil têm em comum uma relação historicamente estreita com a pecuária. A concepção a respeito das formas de trato com os fatores produtivos, ou as relações sociais produtivas, ou mesmo o manejo dos recursos evolui dentro da historiografia brasileira de uma concepção descritivo-isolacionista, presente pela primeira vez em obras clássicas como as de Varnhagen $(1857)^{39}$, Oliveira Lima $(1911)^{40}$ e Oliveira Vianna $^{41}$, para uma diferenciação mais adequada, e rumo a uma diversidade mais apropriada ao estudo de tais relações, em seu caráter dinâmico.

É possível afirmar que até os anos 1940 - época em que Manoel Correia começou a publicar suas primeiras obras sobre a história e geografia nordestinas - a pecuária não foi vista como mais do que uma atividade oscilante entre a complementaridade do setor primárioexportador ora vigente e uma atividade de pequena escala para um mercado interno reduzido. Capistrano de Abreu (1907) pode ser caracterizado como uma exceção a essa perspectiva, ao reconhecer, ainda que de maneira tênue, o papel da pecuária e de suas relações produtivas especialmente nas formas que elas adquirem no território brasileiro - como um dos elementos de sua perenidade frente aos ciclos primário-exportadores, e da própria configuração territorial do Brasil.

A variedade de características regionais da pecuária brasileira somente seria reconhecida a partir dos anos 1940, com os estudos de Roberto Simonsen que resultariam em sua História Econômica do Brasil - Colônia. Nela, contudo, se avançaria pouco mais do que além de tal reconhecimento.

39VARNHAGEN, F. A. de. Historia Geral do Brazil isto é do seu descobrimento, colonisação, legislação, desenvolvimento, e da declaração da independencia e do imperio, escripta em presença de muitos documentos inéditos recolhidos nos archivos do Brazil, de Portugal, da Hespanha e da Hollanda. Rio de Janeiro: Laemmert, dois tomos, 1857.

40LIMA, M. de Oliveira. Formation historique de la nationalité brésilienne, editado em 1911, pela Gallimard, Paris. A edição usada aqui é a 3a. Brasileira da Topbooks de Formação Histórica da Nacionalidade Brasileira, de 2000.

41VIANNA, O. Populações Meridionais do Brasil. Rio de Janeiro: Cia. Ed. Nacional, 1918. 
É a partir dos anos 1950, em especial a partir das edições subsequentes da História Econômica do Brasil, de Caio Prado Júnior (originalmente publicado em 1945) e de Formação Econômica do Brasil (1959), de Celso Furtado, que tais diferenças seriam mencionadas, ainda que de forma resumida, demandando maior informação de estudos e pesquisas acadêmicos em senso estrito. Não deixa de ser notável o fato de que o movimento empírico de abastecimento de informações nas quais os dois últimos autores supracitados vão basear suas assertivas tenha vindo do mesmo lugar que deles parece receber a tarefa de ampliar o volume de informações sobre a pecuária regional.

Como outros exemplos de estudos interessantes que abordam a pecuária regional, há os trabalhos de Sérgio Buarque de Holanda (1956, com Caminhos e Fronteiras), e toda uma gama de pesquisas desenvolvidas no sul e sudeste, com resultados variados. Para o Nordeste, as pesquisas de Manoel Correia se consolidariam em uma primeira síntese: A Terra e o Homem no Nordeste, em 1963.

Na região do Nordeste brasileiro, o gado bovino criado ainda carrega fortes traços dos seus antepassados crioulos, esse tipo do gado fora trazido pelos colonizadores lusitanos. Com grande capacidade adaptativa essa raça foi capaz de sobreviver no severo clima do semiárido nordestino. Entretanto, a consequência de tal adaptação foi um rebanho de baixa produtividade. Os animais que percorriam longas distâncias para saírem dos locais de pastagem e chegar ao abatedouro, tornaram-se musculosos o que diminui a qualidade da carne produzida. A solução dada para esse fato foi a mesclagem da raça crioula, com o gado zebu africano. Manoel Correia de Andrade expõe as linhagens predominantes do gado bovino brasileiro, como sendo:

"No Brasil, graças a tratos especiais, vêm-se desenvolvendo linhagens de gado zebu, como Gir, Guzerá e Nelore, especializadas na produção de leite, embora a maior vocação do mesmo seja para produção de carne. (...) Grande parte do rebanho brasileiro é formado por animais de raças não selecionadas, o crioulo ou pé-duro do Nordeste ou o pantaneiro de sul do mato grosso, de pouco porte e peso e medíocre produtor de leite, e por animais de raças selecionadas, grandes produtores de leite - zona da Mata de Minas Gerais, Estado do Rio ou grandes produtores de carne - Triângulo Mineiro, Oeste de São Paulo, Rio grande do sul.”(ANDRADE, 1976, p. 201) 
Ao analisar-se a composição dos rebanhos nas quatro décadas de 1975 a 2015, no Nordeste, observa-se uma predominância do gado bovino, que vem ganhando importância desde a década de 1970, onde representava $51,19 \%$ dos rebanhos e passou em 2015 a $61,32 \%$ do total criado no Nordeste, cabe pontuar a perda de importância do gado suíno que partiu de uma significância de 28,84\% para $12,26 \%$ do efetivo. Outra mudança notável é a crescente representação do gado ovino, que tinha importância de 15,63\% em 1975, e acumulou em 2015 um total de $23,50 \%$. As mudanças ocorridas no sistema de criação do gado estão ligadas ao surgimento de estabelecimentos no Agreste e na Zona da Mata, nos estados de Pernambuco e Paraíba, onde o cultivo da cana desde de meados da década de 2000 vem dividindo o espaço com criações esporádicas de gado bovino e bubalino, onde antes era criado gado suíno.

Tabela 11: Rebanho efetivo do Nordeste por tipo de gado 1975 - 2015

\begin{tabular}{cccccc}
\hline Nordeste & Bovino & Bubalino & Equino & Suino - total & Ovino \\
\hline 1975 & 18.296 .797 & 37.213 & 1.518 .400 & 10.306 .974 & 5.585 .113 \\
1980 & 21.875 .798 & 83.071 & 1.509 .817 & 7.993 .503 & 6.176 .482 \\
1985 & 23.014 .947 & 113.210 & 1.595 .947 & 8.617 .202 & 6.571 .917 \\
1990 & 26.190 .283 & 174.733 & 1.740 .467 & 9.691 .742 & 7.697 .746 \\
1995 & 23.173 .936 & 110.723 & 1.697 .063 & 9.083 .746 & 6.987 .061 \\
2000 & 22.566 .644 & 85.251 & 1.400 .180 & 7.140 .280 & 7.762 .475 \\
2005 & 26.969 .286 & 121.662 & 1.423 .693 & 7.090 .085 & 9.109 .668 \\
2010 & 28.762 .119 & 120.458 & 1.367 .895 & 6.197 .109 & 9.857 .754 \\
2015 & 29.092 .184 & 130.032 & 1.258 .244 & 5.815 .558 & 11.149 .336 \\
\hline
\end{tabular}

Fonte:IBGE

O surgimento de estabelecimentos criadores de gado encontra-se ligado a uma demanda doméstica inelástica quanto a variações dos preços da carne, associada a uma demanda externa crescente de nações da União Europeia, com destaque para os Países Baixos, e na América latina, com protagonismo do Chile. Tal cenário teve como resultado a alta de preços das carnes que incentivaram a criação de gado. 


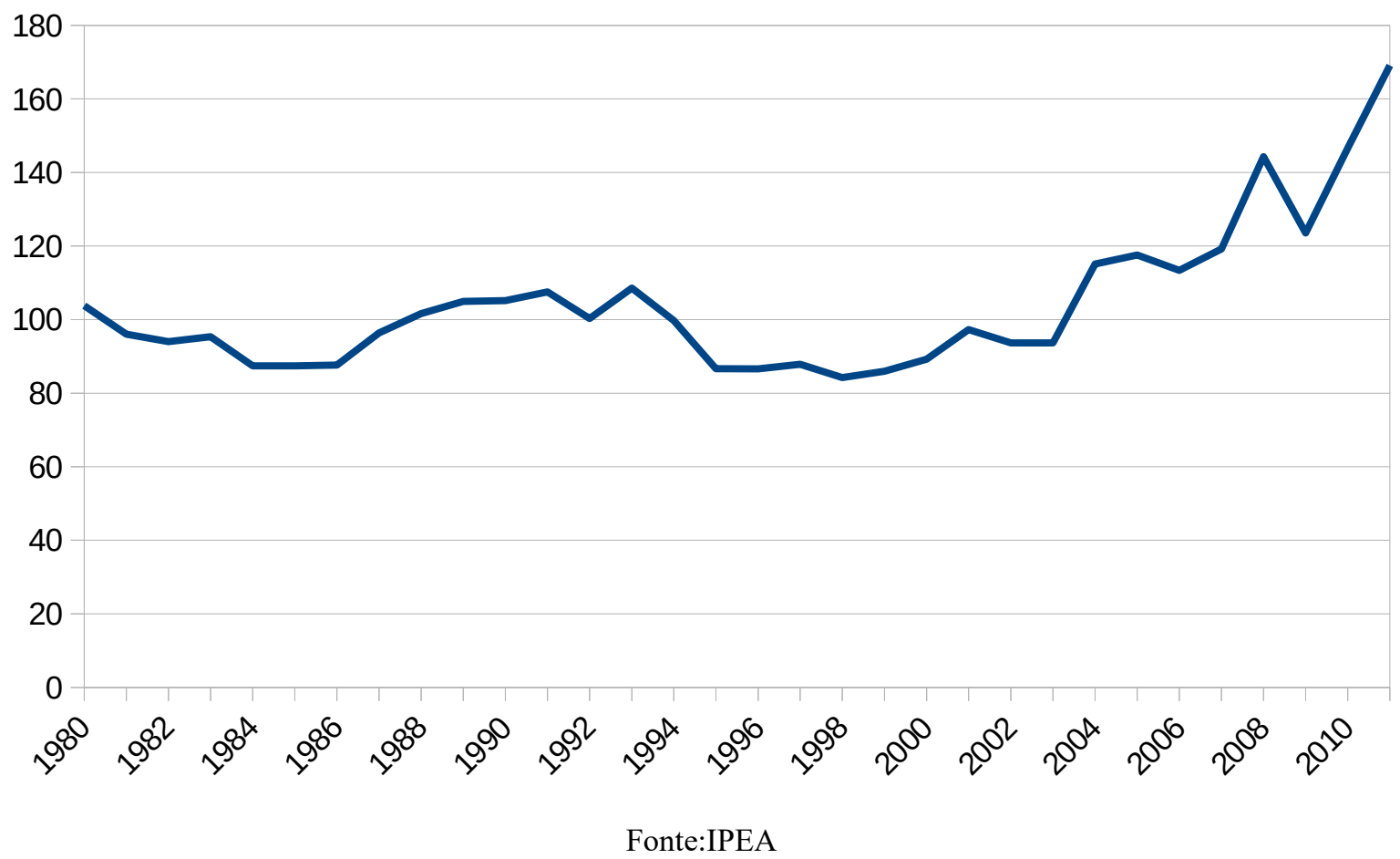

Nas faixas costeiras do litoral ocidental, as áreas de manguezais e terrenos próximos às praias, incompatíveis com o cultivo da cana, são utilizadas no plantio de coqueirais. Os coqueirais criam espaços econômicos dentro dos territórios da cana, e como consequência disso, são limitados pela cana, só adentrando no continente em pequenas áreas ao redor da foz do rio São Francisco, até as proximidades de Penedo. Isso posto, nas áreas praianas o coco é cultivado em grande faixa de forma contínua, Andrade alega que tais faixas:

“(...) o coqueiro domina imperialmente, $\mathrm{Na}$ verdade, apesar de ser, como a cana-de-açúcar, um vegetal exótico, aqui introduzido pelo colonizador português, o coco-da-baía logo se estendeu pelo litoral, ocupando-o em toda a área ora estudada. Sua penetração para o interior depende da largura do terraço arenoso, ora se alargando por quilômetros, como ocorre às vezes em Pernambuco e frequentemente em Sergipe, ora se estreitando a ponto de desaparecer, como ocorre na paraíba, ao sul de João Pessoa, e em Algoas, em certo trecho situado entre Santo Antônio e Maragoji. Algumas vezes esse terraço é seccionado na foz de algum rio, como o Paraíba do Norte, o Goiana, o Serinhaém, o Formoso etc.”(ANDRADE 2010, p. 137) 
Nas últimas duas décadas, foram realizados estudos de levantamento das potencialidades e transformações na cultura do coco, em contribuições como as de Fontes e Wanderley $^{42}$, Cavalcanti, Mota e Silva ${ }^{43}$ e Fontenele $^{44}$. Esses trabalho estão em sintonia com o cenário exposto por Andrade quanto ao espaço econômico e geográfico da produção de coco, assim como a noção de que uma possível indústria com base na produção dos coqueirais deve partir da transformação do atual sistema extrativista arcaico em um sistema moderno de produção industrial, explorando os diversos produtos derivados do coco, como por exemplo, o biodiesel (WANDERLEY, 2006) ou a água de coco (CAVALCANTI, 2006).

Outra cultura que veio a se destacar foi a do cacau na Bahia, estado no qual já fora produzida importante parcela da colheita de cana, hoje representando $0,82 \%$ da produção nacional e $8,57 \%$ do total produzido no Nordeste. Tomando o lugar da cana, encontramos o cultivo do, que criou território próprio, mantendo-se relativamente inalterada a dinâmica alocativa das terras, ainda se perpetuando nos grandes latifúndios que produziam o fruto e delimitavam as áreas das demais culturas. Andrade assim descreve a importância do cacau para o estado como:

“A partir dos fins do século XVIII foram abertas matas a oeste de Ilhéus onde começou a ser cultivado, com sucesso, o cacau, cultura oriunda da Amazônia que aí encontrava solos favoráveis e um clima quente e úmido com chuvas distribuídas durante todo o ano. E o cacau fez a riqueza da região, voltando-a inteiramente para o mercado externo, de vez que mais de $90 \%$ de sua produção é destinada à exportação. Sua Cultura e a riqueza canalizada por ela para a região provocaram migrações de trabalhadores de outras regiões da Bahia e Sergipe, criando aí um sistema agrícola e uma sociedade diferente de quaisquer outros do Brasil."(ANDRADE,2010 p. 144)

A leste do Polígono das Secas encontra-se uma região de cerrado e do litoral setentrional do Nordeste que, hoje, se denomina Meio-Norte. Região inicialmente colonizada por franceses, só veio a se tornar economicamente significativa no século XVIII, quando, no governo de Francisco Xavier de Mendonça Furtado, irmão do Marquês de Pombal, foram

42 FONTES, H. R.; WANDERLEY, M.: Situação Atual e Perspectiva para a Cultura do Coqueiro no Brasil. EMBRAPA, Aracaju, Vol. 94, p. 1 - 16 Novembro 2006

43 CAVALCANTI, J. S. B.; MOTA, D. M da; SILVA, P. C. G. da.:Transformações Recentes nos Espaços de Fruticultura do Nordeste do Brasil, em Difusão do agronegócio e novas dinâmicas socioespaciais. Fortaleza: Banco do Nordeste do Brasil, p. 117 - 149, 2006.

44 FONTENELE, R. E. S.:Cultura do Coco No Brasil: Caracterização do Mercado Atual e Perspectivas Futuras, XLIII Congresso Da Sober, Ribeirão Preto, Julho de 2005 
implementadas medidas de organização da economia maranhense, que até então estava voltado ao autoabastecimento, com o objetivo de suprir a demanda local dos colonos que estavam engajados em guerras constantes com as tribos indígenas (ANDRADE,1970). As guerras contra as tribos locais tiveram seus primórdios na retomada portuguesa do território francês, no qual os franceses estavam estabelecendo um modelo de relação de produção e trabalho diferente do modelo lusitano. Sobre o modelo econômico francês de colonização Andrade aponta que:

"Não se limitaram os franceses, conforme depoimento do próprio D'Abbeville, a desenvolver a extração dos produtos da terra como nos primeiros tempos, comerciando o pau-brasil, as madeiras, o bálsamo, o âmbar e jaspe verde, mas observaram e incentivaram a agricultura indígena do fumo, do milho, da mandioca, do algodão e da pimenta.”(ANDRADE,1970,p. 132)

Durante um breve período de tempo no final do século XVII, os colonizadores portugueses tentaram reproduzir a economia da cana de engenho no Maranhão. Nesse período, surgiram engenhos de açúcar nas regiões da ilha do Maranhão, em Alcântara, Mearim, Itapicuru, Munim e no Gurupi. Entretanto, tais empreendimentos não prosperaram, e foram substituídos a partir de meados do século XVIII pelas culturas do arroz e do algodão.

A organização econômica do norte do Maranhão estabilizou a região assolada pelos conflitos com nativos auxiliados por jesuítas. Isso levou ao aprimoramento da capacidade da capitania de se comunicar com a metrópole portuguesa, estabelecendo fluxo de produtos coloniais, com o desenvolver das culturas do arroz de do algodão, o Maranhão ganhou destaque econômico, entrando em um ciclo econômico ascendente, que Andrade aponta como:

“A expansão da cultura e o aumento da produção do algodão e do arroz teriam consequências que marcariam consideravelmente o maranhão tornando-o, nas últimas décadas do período colonial, uma das áreas mais prósperas e ricas da América Portuguesa. Asssim, ao chegar a independência, a área de povoamento se expandia alcançando o alto Itapicuru, onde o povoamento do Norte alcançou o do sul, oriundo da Bahia, o baixo Pindaré, onde se fundaram duas vilas - 
Viana e Monção - enquanto no litoral surgiam vilas como Guimarães.”(ANDRADE, 1970, p. 140)

O período de prosperidade do algodão e do arroz durou pouco mais de um século, no qual, se formaram os atuais territórios econômicos que dividem o estado em duas partes, o norte agrícola e o sul pecuarista. O norte foi construído pelas culturas do arroz e do algodão com mão de obra escrava africana e indígena de propriedade de colonizadores que chegaram à Ilha e a Alcântara, oriundos da região de Olinda em Pernambuco. Já o território sul teve sua origem com a formação dos grandes latifúndios criadores de gado estabelecidos por colonizadores vindos da Bahia.

Segundo Andrade, o uso das terras do Maranhão continuaria inalterado até o final da década de 1880, tendo a Lei Áurea(1888) sido um dos fatores que iniciaram a recessão das economias do arroz e do algodão. Outro fator fundamental veio do exterior, com a retomada da produção de algodão no sul dos Estados Unidos após a Guerra Civil, e com a entrada do algodão egípcio no mercado europeu (ANDRADE, 1970,).

O algodão, por perder competitividade no mercado internacional desde meados do século XIX, veio a, praticamente, desaparecer na região. Já a recessão da rizocultura vem acontecendo de forma mais gradativa. Nos dias atuais o Maranhão ainda é a maior região produtora do Nordeste voltada ao abastecimento dos estados nordestinos com o grão e, com menor significância, do mercado nacional. Ao analisarmos as décadas de 1975 a 2005 podemos constatar a importância da produção maranhense de arroz para o mercado de arroz no Nordeste.

Tabela 12 percentual da produção nordestina de Arroz 1975 a 2005.

\begin{tabular}{ccccc}
\hline Ano & Maranhão & Piauí & Ceará & Demais Estados \\
\hline 1975 & $70,24 \%$ & $12,19 \%$ & $6,97 \%$ & $10,61 \%$ \\
1980 & $86,37 \%$ & $5,18 \%$ & $1,21 \%$ & $7,24 \%$ \\
1985 & $54,69 \%$ & $23,46 \%$ & $7,85 \%$ & $14,00 \%$ \\
1990 & $54,34 \%$ & $16,66 \%$ & $14,61 \%$ & $14,39 \%$ \\
1995 & $54,93 \%$ & $22,82 \%$ & $11,43 \%$ & $10,82 \%$ \\
2000 & $55,07 \%$ & $18,70 \%$ & $11,23 \%$ & $15,00 \%$ \\
2005 & $56,62 \%$ & $19,19 \%$ & $7,47 \%$ & $16,72 \%$ \\
\hline
\end{tabular}

Fonte:IPEA

A tabela 12 essa traz a participação percentual da produção maranhense em relação ao total produzidos no Nordeste. Percebe-se nela que a predominância do arroz maranhense, embora predominante vem perdendo espaço aos demais estados da região. Tal decadência do arroz, segundo Andrade, é consequência de uma longa perda de rentabilidade iniciada em meados do XIX, com uma forte queda nos preços e perda da mão de obra escrava, algo que, 
por falta de preparo, levaria aos estabelecimentos produtores de arroz a entrar em um ciclo recessivo.

O vácuo deixado pela decadência da economia do algodão foi preenchido pela produção do coco do babaçu, atividade tradicional do estado que prosperava no mercado doméstico desde o auge da era do arroz e do algodão. Transformou-se então um espaço econômico periférico e suplementar às economias dominantes da região, e um dos pilares de manutenção do território econômico. É importante notar tal adaptação, pois é singular no processo de formação dos territórios do "mosaico nordestino". No Maranhão, ocorreu o único exemplo de substituição da atividade dominante, fato que se deve à colonização tardia da região e da não utilização das terras na cadeia produtiva da cana-de-açúcar. Andrade delimita o espaço econômico do babaçu a:

"Na porção norte-oriental do Maranhão domina o babaçual, e as populações pobres que aí vivem dependem em grande parte da coleta do coco de babaçu; as terras outrora cultivadas com algodão e arroz encontram-se quase esgotadas, e o babaçual domina inteiramente a paisagem. Os grandes proprietários, quase sempre comerciantes, funcionários ou industriais nas cidades da região, exploram as terras que possuem, desenvolvendo uma pecuária extensiva e uma atividade comercial complementar."(ANDRADE, 2010, p. 232)

Quanto à produção de coco de babaçu, temos uma situação similar em âmbito nacional e regional, com a vasta maioria sendo produzida no Maranhão. A Tabela 13 traz o percentual da produção para com o total do Nordeste e do Brasil no período de 1986 a 2005. 
Tabela 13 participação percentual da quantidade da produção maranhense de babaçu 1986 - 2005

\begin{tabular}{lrrr} 
Ano & Nordeste & Maranhão & Maranhão/Norc \\
\hline 1986 & $83,27 \%$ & $75,34 \%$ & $90,47 \%$ \\
1987 & $81,87 \%$ & $74,59 \%$ & $91,12 \%$ \\
1988 & $79,98 \%$ & $71,30 \%$ & $89,14 \%$ \\
1989 & $80,21 \%$ & $72,05 \%$ & $89,82 \%$ \\
1990 & $78,15 \%$ & $70,25 \%$ & $89,89 \%$ \\
1991 & $75,63 \%$ & $67,49 \%$ & $89,23 \%$ \\
1992 & $71,47 \%$ & $62,92 \%$ & $88,04 \%$ \\
1993 & $86,47 \%$ & $78,15 \%$ & $90,38 \%$ \\
1994 & $95,06 \%$ & $87,92 \%$ & $92,49 \%$ \\
1995 & $95,88 \%$ & $88,61 \%$ & $92,41 \%$ \\
1996 & $96,28 \%$ & $90,12 \%$ & $93,60 \%$ \\
1997 & $98,02 \%$ & $92,05 \%$ & $93,91 \%$ \\
1998 & $98,17 \%$ & $92,38 \%$ & $94,11 \%$ \\
1999 & $98,22 \%$ & $92,66 \%$ & $94,33 \%$ \\
2000 & $98,31 \%$ & $92,43 \%$ & $94,02 \%$ \\
2001 & $98,41 \%$ & $92,54 \%$ & $94,04 \%$ \\
2002 & $98,37 \%$ & $92,47 \%$ & $94,00 \%$ \\
2003 & $98,24 \%$ & $92,13 \%$ & $93,78 \%$ \\
2004 & $98,20 \%$ & $92,64 \%$ & $94,34 \%$ \\
2005 & $99,16 \%$ & $93,87 \%$ & $94,66 \%$ \\
\hline
\end{tabular}

Fonte: SIDRA - IBGE

Fica clara a importância do coco de babaçu maranhense para a produção nacional da oleaginosa com parcelas crescentes o estado passa de uma significância de 75,34\% em 1986 para um patamar de 93,87\% em 2005. O domínio da cultura fica ainda mais evidente quando estudada a participação em escala regional, em que o babaçual maranhense é responsável por uma média anual de $92,12 \%$ da produção nordestina.

\section{Algumas Considerações Sobre a Indústria do Açúcar e as demais atividades do Nordeste.}

Os estudos de Andrade sobre a formação dos espaços e territórios do Nordeste foram voltados a descrever de que forma as atividades econômicas foram influenciadas pelo meio natural, se organizando no espaço geográfico, consolidando seus espaços econômicos e projetando seus territórios. Trata-se de um sistema imbricado, onde se sobrepõem zonas de influência que determinam os modos e relações de produção. Andrade chega, então, a conclusão que criou-se um Nordeste dividido em grandes zonas produtivas, caracterizadas por atividades dominantes, as quais, agregadas, formam o "mosaico nordestino", estabelecendo as paisagens da região.

Dentre os fatores produtivos nordestinos, a terra e o trabalho se destacam no conjunto das obras do autor, sendo a propriedade do primeiro fator fundamental para compreender a alocação e as condições do segundo. O "Mosaico" de Andrade não seria limitado aos meios 
criados na formação dos espaços econômicos no Nordeste. Cada zona de domínio e transição teria mercados de trabalhos únicos e caracterizados pela adaptação das estruturas produtivas ao longo dos momentos históricos do Nordeste. A história, assim como a política, a economia e a geografia social, seria fundamental para o entendimento das barreiras e potencialidades do desenvolvimento econômico de cada espaço econômico, e formação de novos territórios.

Em obras como "Nordeste, Espaço e Tempo", "A Terra e o Homem no Nordeste" e "Área do Sistema Canavieiro", Andrade deixa a entender que não se pode haver domínios do espaço econômico sem território. A indústria da cana-de-açúcar estende seus tentáculos por grande parte do litoral ocidental, estabelecendo padrões de dispersão das atividades econômicas suplementares na região, servindo, também, em cada etapa de sua cadeia produtiva, como organizadora dos mercados de trabalho, estabelecendo o grau de exploração e utilização da mão de obra na Zona da Mata e o litoral ocidental.

O objeto dos estudos de Andrade é de difícil categorização dentre as ciências, sociais, sociais aplicadas e humano, pelo seu caráter multidisciplinar, algo que, a nosso ver, denota mérito ainda maior na análise do professor. Lançando mão de uma rede muito mais ampla de conceitos e metodologias da geografia, história e economia, Andrade conseguiu perceber que os territórios das atividades dominantes avançam para além de suas fronteiras geográficas, sendo condicionados, não só pelas configurações produtivas atuais, mas também por uma herança histórica de adaptação dos territórios. Assim umas das contribuições de Manoel Correia de Andrade para a análise da história econômica do nordeste foi seu olhar multidisciplinar sobre as zonas de domínio em constante processo de transformação e adaptação na região moldando no tempo os espaços que compõem o "Mosaico Nordestino".

Ademais, é possível apontar um outro mérito, de duplo caráter, na obra de Manoel Correia de Andrade sobre o Nordeste: se por um lado, sua análise não se mantém estanque no tempo, sofrendo adaptações e reflexões frente ao factual, por outro, boa parte de suas linhas gerais de resultados analíticos encontra aderência em estudos empíricos realizados até muito depois de sua morte. Isso mostra dois dons de Manoel Correia como intelectual, ambos valiosos: o da humildade intelectual e o da aderência à realidade concreta. 


\section{CAPÍTULO 3: Urbanização, Território E Subdesenvolvimento Nordestinos Em Manoel Correia De Andrade,1973 -1998}

\section{Introdução}

Entre as décadas de 1950 e 1980, o Nordeste Brasileiro vivenciou um período de modernização dos modos produtivos da agropecuária, com a incorporação subsidiada de maquinário. As consequências dos avanços tecnológicos assimilados foram: (I) aumento da produtividade, (II) aumento da oferta de terras, devido às obras de infraestrutura em eletrificação, pavimentação de rodovias e saneamento, e (III) substituição da mão de obra por maquinário, aumentando, com isso, o número de máquinas por trabalhador empregado no campo. A nova dinâmica capitalista que se consolidaria na região traria consigo um fenômeno já observado na região sudeste o êxodo rural, fator de fundamental importância para se compreender a crescente significância da população urbana, com aumento de 119,25\% de 1970 a $1991^{45}$.

Com a implementação de uma sistemática de produção capitalista moderna sobre as estruturas produtivas o campesinato nordestino, elementos da herança colonial foram substituídos por novas formas de organização social como, por exemplo, a transformação da economia centrada na atividade primário-exportadora dos engenhos banguês, a qual sustentava a posição de dominação política dos senhores de engenho, para uma economia industrial exportadora centrada na produção de açúcar refinado e de álcool etílico das usinas. Uma das repercussões do processo de modernização das estruturas produtivas do campo no Nordeste foi a intensificação do êxodo rural e o crescimento desordenado das cidades. Sobre esse processo, Andrade levanta a hipótese de que as massas trabalhadoras desempregadas pelo progresso tecnológico no campo foram alocadas para os centros urbanos criando uma "população marginalizada" incapaz de ser integrada às principais atividades econômicas dos centros urbanos (ANDRADE, 1998).

Nesse período, entre as décadas de 1970 a 1990, Manoel Correia de Andrade escreveu duas edições de "A Terra e o Homem no Nordeste", atualizando-a para incorporar, em sua análise, as mudanças provocadas pela consolidação do sistema empresarial que viria a se disseminar com a predominância do moderno setor Sucroalcooleiro.

As transformações de 1973 a 1998, no entanto, trariam consigo uma nova forma adaptada da antiga dominação colonial. De fato, elementos como a concentração da posse de

45Fonte: IBGE, Censo demográfico 1940-2010. Até 1970 dados extraídos de: Estatísticas do século XX. Rio de Janeiro: IBGE, 2007 no Anuário Estatístico do Brasil, 1981, vol. 42, 1979. 
terras tenderiam a se intensificar. Andrade proporia um condicionante histórico à interpretação do Nordeste que, unido ao condicionante físico, moldaria sociedade e economia nordestinas, desde os primórdios coloniais, adaptando o domínio político às tentativas de superação dos gargalos econômicos e consolidando com isso elementos estruturais de uma sociedade arcaica.

Este capítulo busca realizar uma revisão bibliográfica do autor, sob a temática do processo de urbanização e marginalização dos trabalhadores. Para isso, estruturou-se esta argumentação da seguinte maneira: uma breve introdução (I), seguida por uma seção dedicada a determinar quais seriam os elementos componentes do fenômeno da urbanização, buscando definir as formas que os centros urbanos tomariam no período estudado e qual o papel da economia rural na criação e transformação das cidades (II). Em seguida, trataremos da observação dos dados que possam agregar clareza as transformações que ocorreram na região do Nordeste brasileiro (III). Numa quarta seção, temos a exposição do sentido que Manoel Correia de Andrade atribuía à produção urbana (IV). A quinta sessão traz os debates quantos as formas e consequências da urbanização, explorando as teorias dos polos de crescimento e das massas marginalizadas (V). Por fim, temos uma sessão para levantar algumas considerações sobre a urbanização e a hipótese de Manoel Correia de Andrade (VI).

\section{O Fenômeno da Urbanização}

A categorização entre as regiões urbanas e rurais no Brasil teve, desde sua concepção legal, um caráter administrativo legal, com o decreto-lei no. 311, de 12 de março de 1938, o qual estipulou que as regiões urbanas seriam definidas por leis municipais, nas quais se estabeleceriam os perímetros urbanos da sede municipal e das vilas ou distritos. Assim, toda área externa a tal perímetro seria considerada zona rural (IBGE, 2011). Entretanto, o estabelecimento puramente jurídico de regiões ditas urbanas ou rurais é uma forma de classificação desprovida de qualquer aspecto social, econômico e até mesmo de impactos demográficos quantitativos, como o contingente ou o volume da população, por exemplo. Para, então tratarmos da urbanização de forma empírica, é necessário explanar o que seria a urbanização e quais seus elementos.

A urbanização, empiricamente, nada mais é do que o aumento da significância da população que vive em zonas urbanas em relação a população total de uma nação. Isso não significa dizer que tal fenômeno ocorra sempre pelas mesmas razões, muito menos que as causas e consequências da urbanização sejam de caráter puramente quantitativo. O fluxo migratório campo - cidade, como decorrido no Brasil desde o início do século XX, causou 
mudanças na organização social do país, de maneira a impactar as formas econômicas, políticas e sociais no país. As regiões rurais passaram a ser vistas como "atrasadas" e “incapazes” de propiciar padrões elevados de renda. Já as cidades passaram a ser consideradas a vanguarda da vida industrial moderna, capazes de oferecer uma vida mais rica e próspera. Tal concepção revelou-se mais fantasiosa que verídica, e levou à criação de comunidades periféricas que circundam os centros urbanos, mas cuja população não usufrui das benesses sugeridas por estes, gerando um contingente de excluídos do projeto desenvolvimentista industrial de urbanização.

No caso do Nordeste brasileiro, tal processo evoluiu de forma atrasada em comparação às regiões do Sul e Sudeste. Foi somente com a modernização das técnicas e máquinas do setor da agropecuária a partir do final da década de 1950, que se transferiu um sistema organizacional capitalista "moderno" em oposição às antigas estruturas produtivas do campo. Segundo Manoel Correia, as consequências da modernização do campo foram:

“(...) uma sociedade em que coexistiam formas de exploração capitalistas, visando à produção para exportação e pré-capitalistas, visando à produção para o auto-abastecimento do agricultor e para o abastecimento da região, foi provocando um desequilíbrio. Desequilíbrio que resultou na expansão das atividades capitalistas agroindústria canavieira, cafeicultura, pecuarização e etc. - por áreas antes desocupadas ou dedicadas a cultura de exportação, e desapropriou e empobreceu grupos pobres, dedicados à produção para o mercado interno. Tal desequilíbrio provocou o êxodo rural e o crescimento desordenado das cidades, a princípio de grande porte, e, posteriormente, as de médio e pequeno porte." (ANDRADE, 1998 p. 224)

Paralelamente e consequentemente à implementação do modelo econômico brasileiro $^{46}$, se consolida a população urbana como majoritária no Nordeste (ANDRADE, 1998). Para nos aprofundarmos na análise do fenômeno é preciso, no entanto, realizar um aposto para definir o que se trata como campo e o que se trata como cidade, para dai podermos expor a análise empírica dos dados sobre a urbanização.

46 Esse aspecto encontra-se discutido com maior detalhe no capítulo 4 desta dissertação. 
A aglomeração da maior parte da população em centros urbanos no decorrer da história se deu por diversos motivos sociais, econômicos e/ou políticos, fazendo com que seja necessário especificar qual dos diversos movimentos migratórios no sentido campo - cidade, se pretende analisar. De maneira ampla, todas as nações que passaram por um processo de industrialização tenderam a aglomerar suas populações nos centros urbanos (SINGER,1973). À medida que a modernização do maquinário agrícola, faz com que a massa de trabalhadores rurais necessárias a execução das atividades do campo torne-se cada vez menor, cria-se um excedente de oferta de mão de obra no campo, que de maneira geral, tende a se deslocar para a cidades em busca de condições de vida melhores. Manoel Castells aponta para o fato de que as aglomerações em cidades não é algo inerente à história contemporânea ao expor que:

“As investigações arqueológicas mostram que os primeiros aglomerados sedentários e com forte densidade de população (Mesopotâmia, por volta de 3.500 A.C, Egito 3.000 A.C, China e Índia, 3000-2500 A.C) aparecem no fim do neolítico, no momento em que as técnicas e as condições sociais e naturais do trabalho permitem aos agricultores produzir mais do que tinham necessidade para subsistir. A partir deste momento um sistema de divisão e de distribuição se desenvolve, como expressão e desdobramento de uma capacidade técnica e de um nível de organização social.”(CASTELLS, 2000 p.42)

Levando em conta o processo histórico de formação de aglomerações populacionais, para definir a urbanização nos moldes nos quais ela veio a ocorrer no Brasil e no Nordeste do século XX, autores como Paul Singer e Manoel Castells diferenciam o fenômeno da urbanização moderna, ao atribuir a formação de uma economia fabril e industrial, a partir da Primeira Revolução Industrial, a causa da intensificação do êxodo rural. No caso do Nordeste Brasileiro, Andrade analisa a crescente população urbana em função de: (1) modernização do campo e (2) surgimento de um setor industrial exportador dominante, qual seja a agroindústria canavieira, cafeicultura, cacauicultura ou peculiarização (ANDRADE, 1998).

Andrade inicia seus estudos sobre o papel centralizador das cidades em sua obra “Espaço, Polarização e Desenvolvimento" publicada em 1967, se aprofundando em sua obra “Cidade e Campo no Brasil" publicado em 1974. Nela, partindo de uma base teórica dos polos de crescimento elaborada pelo François Perroux ${ }^{47}$, teoriza que as cidades teriam zonas

47 Em PERROUX. F.: L'Economie du Xxe siècle. Paris, Presses Universitaire de France, 1964. 
de influência que iriam além de suas fronteiras urbanas moldando as economias rurais, criando e fortalecendo uma relação de dependência do campo para com a cidade que lhe forneceriam produtos industriais(ANDRADE, 1974). A formação dos territórios urbanos capazes de integrar as economias do campo e da cidade só viria a ocorrer com o desenvolvimento prévio de meios de transporte e comunicação. Assim, Andrade aponta que:

"Só modernamente após a terceira década do século XX, é que se caracterizou bem uma hierarquização das áreas de influência das várias cidades brasileiras e, graças às facilidades de transportes e comunicações, as cidades foram crescendo e ampliando as suas áreas de influência; se analisarmos o crescimento da população da maioria das grandes cidades brasileiras no período de 1872 - 1900 cremos que elas pouco cresceram e algumas cidades, estendendo seus tentáculos estradas de ferro ou de rodagem - de influência, captaram para si mesmas várias regiões homogêneas, consolidando ou criando relações de dependência em relação a outros centros urbanos, que conheciam uma fase de estagnação ou crescimento menos dinâmico.”(ANDRADE, 1974, p.88)

A urbanização, teria então, suas raízes uma nova configuração da divisão social do trabalho, que, embora ocorrendo em épocas distintas, com os primeiros iniciando seus processos de urbanização no século XVIII, e os segundos, somente iniciando a urbanização no século XX, tornam as cidades centros produtivos industriais que passam a estabelecer uma situação de troca de bens industrializados com o campo. É nos modos dessa troca que se intensificaram os movimentos migratórios entre as regiões urbanas e rurais, sendo a cidade vista como um mercado capaz de absolver a mão de obra que o campo já não podia contemplar, o que é verdade tanto para o campo quanto para as cidades e levou à criação de massas de trabalhadores empregados em atividades cada vez menos importantes para o funcionamento do sistema produtivo.

Antes de adentrarmos na questão do que é a cidade, qual a composição e seu território e qual a extensão de sua zona de influência, cabe agora, discorrer sobre o que é o campo, a outra parte de um sistema dual que compõe todas as nações do mundo moderno, o campo tem seu lugar na divisão social do trabalho a produção dos bens de consumo diretamente provenientes da terra. Paul Singer, em sua obra "Economia Política da Urbanização”, viria a definir e diferenciar campo e cidade da seguinte maneira: 
“(...) “Campo" é o lugar onde se dá a atividade primária, onde o homem entra em contato direto, primário, com a natureza, dela extraindo as substâncias que vão lhe satisfazer as necessidades. A transformação final destas substâncias pode-se dar no campo ou na cidade, mas a sua produção primeira, sua separação do meio natural, mediante a extração, cultivo ou criação, se dá necessariamente no campo. Este tipo de atividade é, portanto, um monopólio do campo. Não importa se na cidade também vivem cultivadores, entre as atividades urbanas fundamentais não se incluí a agricultura.(...) O que caracteriza o campo, portanto, em contraste com a cidade, é que ele pode ser - e, de fato, muitas vezes têm sido - auto-suficiente. A economia natural é um fenômeno essencialmente rural.” (SINGER, 1973, P.12)

Dessa forma, no moderno sistema capitalista, o campo teria como funções centrais: (I) a produção de excedentes para serem utilizados como matéria-prima na produção das cidades e (II) o abastecimento de produtos alimentícios básicos para a sustentação das massas trabalhadoras das cidades. A existência do excedente da economia natural se fez necessária ao surgimento e desenvolvimento das economias industriais urbanas modernas. Dada a posição da economia rural na divisão social do trabalho, em que a produção se dá para o autoabastecimento e o suprimento da cidade, criou-se então um território de domínio das atividades econômicas urbanas, onde são processados os excedentes do campo, que serão revendidos como produtos industriais acabados para o campo e para as massas assalariadas da cidade.

O processo histórico que levou à consolidação das relações de troca entre a cidade e o campo, fosse nas economias desenvolvidas ou subdesenvolvidas, se deu de maneira gradual, tendo suas origens na Primeira Revolução Industrial, no século XVIII, quando a evolução da atividade fabril na Inglaterra e o cercamento das terras inglesas para a produção de lã causou um processo de êxodo no campo e concentração demográfica nas cidades. A partir do início da Revolução Industrial, as áreas urbanas começaram a se desenvolver, de maneira que:

“(...)O centro dinâmico deste processo é a cidade, que multiplica suas atividades de duas maneiras: a) capturando atividades antes exercidas no campo e as incorporando à sua economia e b) criando novas atividades mediante a produção de novas técnicas e/ou novas 
necessidades. A distinção entre essas duas maneiras é dificultada pelo fato de que as atividades anteriormente exercidas no campo ressurgem, na cidade, transformadas mediante inovações técnicas e/ ou organizacionais, de modo que se confundem com atividades inteiramente novas, de cunho exclusivamente urbano." (SINGER, 1973, P.20)

As cidades então tomaram seu formato contemporâneo, a partir do momento em que passaram de centros comerciais, onde aqueles que tinham o controle das terras gastavam o excedente das atividades rurais que dominavam, e passaram a ser centros onde toda a produção agrícola se transforma em produto fabril. Singer define a cidade moderna como:

“(...) a cidade ficou sendo o lugar no qual se concentra não apenas o excedente alimentar produzido no campo, mas toda a produção agrícola, a qual é comercializada, transformada industrialmente e, em parte, redistribuída ao campo a partir da cidade. Do outro lado, a “industrialização" da agricultura permitiu imensa expansão das forças produtivas no campo ou, mais precisamente, um aumento formidável da produtividade do trabalho agrícola." (SINGER, 1973 P.27)

A urbe como aglomeração de populações não é um fenômeno homogêneo. Embora pareça fácil determinar uma zona urbana, no tocante à composição das classes sociais que habitam as cidades, se encontram padrões de renda e consumo absolutamente incomparáveis. A diferença na participação da renda nacional entre os empregados e os empregadores cresceu, a partir de então, em todo o mundo capitalista, tendo ocorrido de maneira mais notável nos países periféricos (SINGER, 1973). Nestes, as cidades tomaram formas específicas, com bairros ricos cercados por bairros pobres, com a maior parte da população economicamente ativa voltada ao mercado de serviços e ao comércio. Formou-se assim um território urbano heterogêneo e organizado pelos detentores dos fatores de produção, sejam eles agentes internos aquela economia ou agentes internacionais, dando o viés do processo de desenvolvimento socioeconômico a favor da concentração de riqueza e bem-estar.

O espaço urbano, então, parece sintonizado com o espaço ocupado pelo território econômico das atividades capitalistas industriais. Ou seja, o território ocupado pela área de influência da organização dos fatores produtivos estabelecida no processo de industrialização, dentre as indústrias Paul Singer dá ênfase a indústria de transformação apontando que 
“(...) é a atividade urbana por excelência. A técnica industrial moderna requer o uso de equipamentos muito grandes, cuja movimentação exige enorme quantidade de braços. Para produzir barato 'preciso produzir em massa. Isso faz com que não apenas as fábricas sejam de amplas dimensões mas também que muitas delas - que exercem atividades complementares - se agrupam na mesma área." (SINGER P. 137)

Dessa forma, a indústria de transformação teria um território que agiria como uma força centrípeta sobre a distribuição dos trabalhadores, gerando aglomerações populacionais por onde esse tipo de indústria se desenvolveria. Cabe aqui apontar que os limites do território industrial não se limitam às fronteiras de um município, de um estado ou, até mesmo, de uma nação. Exemplo claro disso são os fluxos migratórios da região Nordeste para o estado de São Paulo entre as décadas de 1920 a 1960.

Outro autor que deu à indústria o papel central na análise e definição das cidades foi o sociólogo espanhol Manoel Castells, que associa a formação de uma identidade cultural urbana à "complexidade social e técnica" do desenvolvimento das indústrias capitalistas modernas, apontando que:

“Tratar-se-ia, então, principalmente, de uma "cultura industrial”. O fator tecnológico da industrialização seria então o elemento principal determinante da evolução das formas sociais. Estaríamos próximos então das teses sobre a "sociedade industrial"." (CASTELLS, 2000 p.135)

A correlação entre o processo de urbanização e a criação de um setor industrial relevante também é notada por Milton Santos, que ao estudar a evolução dos processos de urbanização em países desenvolvidos e subdesenvolvidos, aponta que: "é preciso reconhecer que se pode constatar, grosso modo, certo paralelismo entre nível de urbanização, de industrialização e outros indicadores socioeconômicos (...)”(SANTOS, 2012, p.29) O fenômeno da urbanização foi categorizado como as aglomerações populacionais, ocorridas no processo de consolidação da produção industrial do mundo capitalista moderno. Assim sendo, cabe-se agora nos perguntarmos quais as formas que tal processo veio a tomar na região Nordeste do Brasil. 
As especificidades dos processos de urbanização nas nações do mundo capitalista moderno seriam resultados de seus recursos naturais e de forma com que suas heranças históricas viram a influências as organizações socioeconômicas atuais. Entretanto, Santos ao estudar a urbanização em países desenvolvidos e subdesenvolvidos percebe alguns elementos diferenciais chaves. O geógrafo aponta que:

"No processo de urbanização, uma das diferenças entre países industrializados e países subdesenvolvidos prende-se ao de que naqueles a população agrícola contada, seja globalmente seja pelo número de homens ativos, cai rapidamente, enquanto nos países subdesenvolvidos essa revolução é muito mais lenta."(SANTOS, 2012, p.34)

Andrade, em suas tentativas de aplicar a teoria dos pólos de crescimento à realidade nordestina, aponta que a função administrativa das cidades seria outra caraterística distinta do processo de urbanização em economias subdesenvolvidas (ANDRADE, 1970). Nas cidades do Nordeste brasileiro, na maioria dos casos, não foi a industrialização urbana o setor impulsionador da urbanização. Tal papel teria recaído por sobre o setor de serviços e o aspecto administrativo organizacional que os centros urbanos tiveram na modernização do maquinário utilizado nas regiões rurais.

\section{A Urbanização do Nordeste em Dados}

Para se averiguar se realmente transpareceu uma urbanização com marginalização da população, faz-se necessário partir da observação de como tem se comportado a distribuição da população entre as áreas rurais e urbanas do nordeste. O gráfico 9, elaborado com dados coletados junto ao IBGE, mostra como evoluíram as variáveis população urbana e população rural para a região, no decorrer das décadas de 1970 a década de 2000. 
Gráfico 9. População nordestina em regiões urbanas e rurais

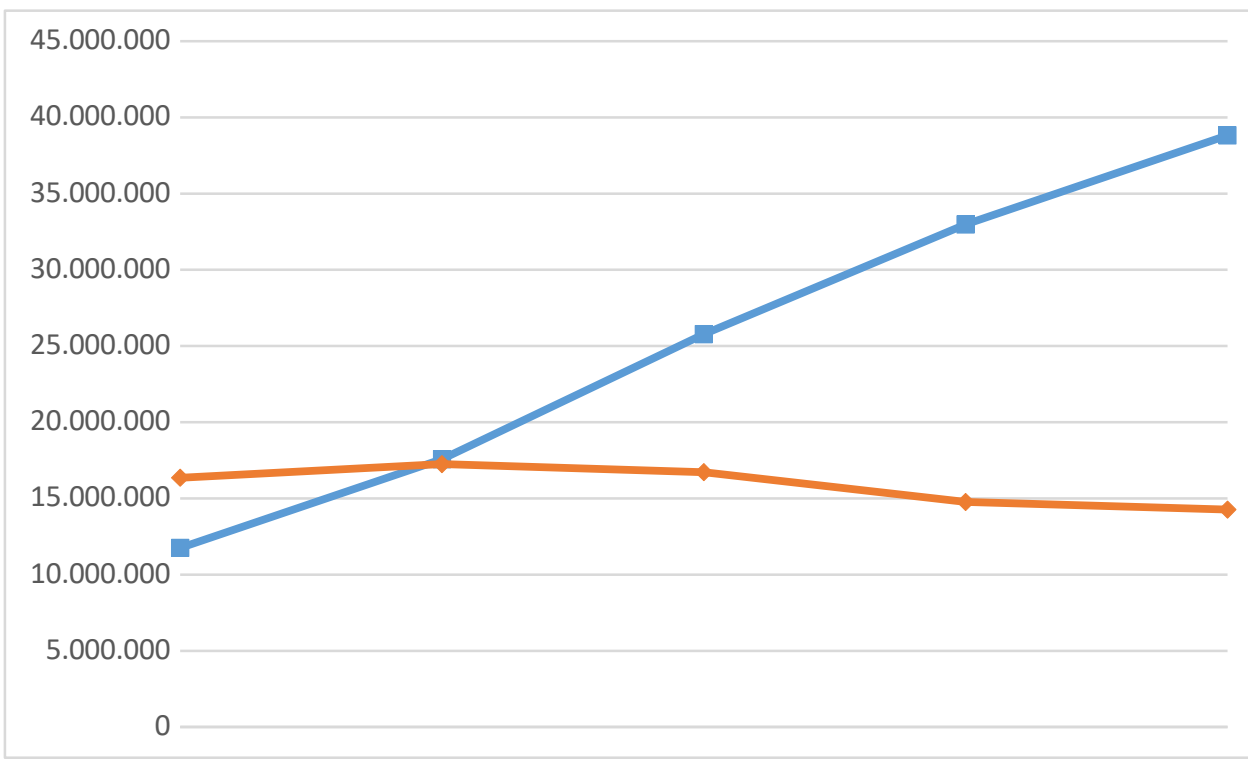

Fonte: IBGE, Censo demográfico 1940-2010. Até 1970 dados extraídos de: Estatísticas do século XX. Rio de Janeiro: IBGE, 2007 no Anuário Estatístico do Brasil, 1981, vol. 42, 1979.

Pode-se observar que nas décadas de 1970 e 1980 o Nordeste brasileiro vivenciou um momento de transformação, em que a maior parte de sua população passou a se encontrar nas regiões urbanas. Em 1970, aproximadamente 16,355 milhões de pessoas habitavam zonas rurais, o que representava $58 \%$ de todos os nordestinos, com as urbes representando, com seus 11,756 milhões de habitantes, $42 \%$. Esse quadro se altera já no primeiro ano da década de 1980 com uma explosão populacional tendo o número de indivíduos que tinham residências urbanas aumentando 49,43\% com relação a 1970, atingindo assim o patamar de 17,568 milhões.

A tendência de crescimento populacional nos centros aglutinadores continuou nas décadas de 1980, 1990 e 2000, com aumentos de 46,77\%; 28\% e 17\%, respectivamente. Esse momento é acompanhado pela estagnação do volume demográfico no campo, que em 1980 teria aumento de 5,45\% não ultrapassando a marca de 17,250 milhões de habitantes. De fato, pode-se observar um movimento contrário na variável população rural, que em 1991 teria reduzido 3,05\% com relação a 1980, continuando a reduzir-se nas décadas de 1990 e 2000, com variações percentuais de $-11,69 \%$ e $-3,42 \%$.

Somente a variação do volume de pessoas que residem em áreas urbanas e rurais não é o suficiente para descrever o movimento populacional que ocorreu durante as quatro décadas estudadas. Para isso, deve-se considerar o crescimento populacional como sendo a soma do crescimento vegetativo, como função da taxa de natalidade menos a taxa de 
mortalidade, com o crescimento migratório, como resultado de imigrações menos emigrações (SOUZA, 2006). Partindo somente das variáveis agregativas temos então três possíveis explicações para explosão populacional nos centros, sendo essas:

1. Crescimento devido a nascimentos na região

2. Imigrações do exterior

3. Migrações de regiões de rurais para urbanas

Ao se tratar da taxa de natalidade, utilizamos uma variável proxy da taxa de fecundidade. A tabela 14 traz a taxa de fecundidade como a proporção entre filhos por mulher para as regiões urbanas e rurais do nordeste de 1970 a 2000.

Tabela 14. Taxa de fecundidade(filhos/mulher) por situação da região urbana ou rural

\begin{tabular}{ccc}
\hline Ano & $\begin{array}{c}\text { Nordeste } \\
\text { Urbano }\end{array}$ & $\begin{array}{c}\text { Nordeste } \\
\text { Rural }\end{array}$ \\
\hline 1970 & 6,6 & 8,5 \\
\hline 1980 & 4,9 & 7,7 \\
\hline 1991 & 2,9 & 5,3 \\
\hline 2000 & 2,3 & 3,8 \\
\hline
\end{tabular}

Fonte: Fonte: IBGE, Censo demográfico 1940-2010. Até 1970 dados extraídos de: Estatísticas do século XX.

Rio de Janeiro: IBGE, 2007 no Anuário Estatístico do Brasil, 1981, vol. 42, 1979.

O cenário que a tabela 14 nos mostra é uma tendência de redução na taxa de fecundidade das mulheres no campo e nas cidades, dessa forma é de se esperar, ceteris paribus, uma tendência de desaceleração nas taxas de crescimento populacional, o que vai de encontro com o observado no gráfico 9 A explosão populacional então ficaria em função dos fatores de deslocamento populacional.

Considerando somente as taxas de fecundidade no campo e nas cidades era de se esperar um crescimento da população campesina acima do crescimento das cidades, isso, num entanto, não se observou muito pelo contrário na segunda metade do século $\mathrm{XX}$ as populações urbanas se tonaram preponderantes. Para entender melhor esse fenômeno precisamos observar o posicionamento do Nordeste junto aos fluxos migratórios do país. A tabela 15 nos mostra a taxa de imigração liquida das grandes regiões do Brasil, ou seja, o valor marginal de crescimento percentual da população na forma de imigrações para a região, entre os períodos de 1950 a 1980, com periodicidade decenal.

Uma outra fonte de crescimento populacional é a imigração para a região, para interpretarmos tal variável utilizamos a taxa de imigração liquida exposta na tabela 15 para o 
período de 1950 a 1980, com periodicidade decenal. Tal taxa nos mostra a variação percentual da população total causada pela imigração, ou seja, o valor relativo do aumento populacional dado o saldo entre as emigrações e as imigrações.

Tabela 15. Taxa de imigração liquida (\%)

\begin{tabular}{ccccc}
\hline Regiao & 1950 & 1960 & 1970 & 1980 \\
\hline Norte & 12,12 & 9,72 & 9,9 & 18,16 \\
Nordeste & 5,47 & 6,31 & 5,93 & 6,49 \\
Sudeste & 11,9 & 13,71 & 16,57 & 18,45 \\
Sul & 10,94 & 16,83 & 17,5 & 14,06 \\
Centro-Oeste & 20,69 & 29,38 & 32,84 & 35,14 \\
\hline
\end{tabular}

Fonte:IBGE, Censo Demográfico 1950-1980. Tabela extraída de: Estatísticas do Século XX. Rio de Janeiro : IBGE, 2007 no Anuário Estatístico do Brasil 1982, vol 43, 1982.

O Nordeste, então, mostrou-se como a região com menor dinâmica de imigração, com uma taxa de imigração média de $6,05 \%$ nos anos observados, tendo isso ocorrido pelo forte fluxo emigratório de trabalhadores de origem nordestina que buscaram meios de sobrevivência em outras regiões. Isso pode ser observado se levarmos em consideração que regiões como Sudeste e Centro-Oeste mostraram desempenhos superiores à média nacional da taxa de imigração, que para o período foi de $12,87 \%$, tendo as duas regiões mencionadas médias de $15,16 \%$ e $29,51 \%$, respectivamente. Contudo, cabe observar também que, embora em menor escala, se a população imigrante para o Nordeste cresceu em valores absolutos, em momento nenhum no período analisado a taxa de imigração caiu a valores negativos, o que leva a necessidade de estudo da composição das populações rurais e urbanas, no sentido de avaliar-se uma possível tendência de mudança de composição entre as zonas rurais e urbanas.

A evolução do número de habitantes por município no Nordeste revela como progrediu a urbanização no processo de difusão e concentração dos centros urbanos. A tabela16 nos mostra a evolução do número de municípios por classe de tamanho populacional em valores relativos percentuais, no período de 1950 a 1991, com periodicidade decenal. 
Tabela 16. Número de municípios por classe de tamanho populacional (\%).

\begin{tabular}{|c|c|c|c|c|c|c|c|c|c|}
\hline \multicolumn{10}{|c|}{ Cidades (\% do total) } \\
\hline Período & Até 500 & $501-1000$ & $1001-20002001$ & $\begin{array}{r}5001 \\
-500010000\end{array}$ & & $\begin{array}{l}10001- \\
20000\end{array}$ & $\begin{array}{l}20001- \\
50000\end{array}$ & & \\
\hline 1950 & 1,15 & 13,14 & 33,5 & 33,17 & 10,84 & 4,43 & & 2,13 & 1,64 \\
\hline 1960 & 2,1 & 13,73 & 28,02 & 34,55 & 11,52 & 6,64 & & 1,77 & 1,66 \\
\hline 1970 & 5,31 & 15,63 & 25,29 & 31,03 & 12,21 & 5,74 & & 3,05 & 1,74 \\
\hline 1980 & 1,67 & 8,15 & 20,87 & 34,91 & 17,89 & 8,51 & & 5,31 & 2,69 \\
\hline 1991 & 0,4 & 3,05 & 15,11 & 34,19 & 23,33 & 13,25 & & 7,09 & 3,58 \\
\hline
\end{tabular}

Fonte: IBGE, Censo demográfico 1950/2010

Com os dados, podemos inferir que houve um aumento relativo do número de cidades de maior porte, sendo que as cidades com menos de 2.000 habitantes em 1950 representavam aproximadamente $47,8 \%$ do total de cidades no Nordeste, passaram em 1991 a 18,6\% do total. Essa mesma tendência se reverteu para as cidades com mais de 2.000 habitantes, com especial ênfase nas cidades entre 5.001 e 20.000 habitantes, que em 1950 tinham significância de $15,3 \%$ das cidades, e passaram em 1991 a representar 36,6\%. Cabe fazer a ressalva quanto à classe de cidades com mais de 50.000 habitantes. Essas nunca se mostraram preponderantes no conjunto de dados analisados mas englobam cidades como Recife, Fortaleza e Salvador que, se somadas, chegaram a conter $12,09 \%$ da população do Nordeste. O processo de crescimento das capitais do litoral oriental já havia sido identificado do Andrade, que em sua obra "Geografia Econômica do Nordeste" publicada em 1977 aponta que: "Podemos colocar apenas três cidades que possuem uma população bastante elevada (...) e que funcionam como metrópoles cuja influência se estende fora do estado em que são situadas. São elas: Recife, Salvador e Fortaleza. ”(ANDRADE, 1977, p.43)

A partir de 1980, temos, então, o processo de difusão dos pequenos e médios municípios, com o ganho de representatividade dos municípios com mais de 20.000 habitantes

“(...) o fenômeno urbano teve grande aceleração, não só pelo crescimento da população das grandes cidades a vários milhões de habitantes como pelo aparecimento de milhares de cidades pequenas e médias a partir do século XIX. E o crescimento destas cidades esta ligado ao desenvolvimento de técnicas agrícolas que permitiram o abastecimento das mesmas em víveres - crescimento da produtividade agrícola por hectare cultivado e por homem-dia empregado como 
também pelo desenvolvimento dos meios de transporte e comunicação.” (ANDRADE, 1974, p. 87)

Durante a segunda metade do século XX, um processo de ampliação do setor de serviços inicia-se, de maneira que o Nordeste não é excluído da tendência nacional. O Quadro 2 mostra o PIB a custo de fatores, discriminado em três setores da economia nordestina, em valores absolutos, tendo como unidade de medida o Real a preços de 1980. Além disso, explicita também o valor total produzido a preços de fatores dentro do nordeste.

Quadro 2. Brasil, Nordeste, PIB a custo de fatores(1965/1995)

(1965 a $1985=$ setor/PIB; 1985 a 1995 = reais deflacionados a preços de 1980)

\begin{tabular}{|c|c|c|c|c|}
\hline \multirow{2}{*}{ ANOS } & \multicolumn{3}{|c|}{ SETORES ECONÔMICOS } & \multirow{2}{*}{ TOTAL } \\
\cline { 2 - 5 } & Agropecuária & Indústria & Serviços & 0,0019 \\
\hline 1965 & 0,00055 & 0,00044 & 0,00091 & 0,00774 \\
\hline 1970 & 0,00162 & 0,00212 & 0,004 & 0,04212 \\
\hline 1975 & 0,01007 & 0.01163 & 0,02042 & 0,56215 \\
\hline 1980 & 0,09701 & 0,16493 & 0,30021 & 71,46489 \\
\hline 1985 & 11,59852 & 21,54688 & 38,31949 & $1.806 .516,03$ \\
\hline 1990 & $231.744,12$ & $496.806,93$ & $1.077 .964,99$ & \\
\hline
\end{tabular}

Fonte: SUDENE. Agregados econômicos regionais do nordeste do Brasil 1965-98,Recife, 1999,p.17

O quadro anterior mostra um processo de concentração na produção no setor de serviços. Quanto a essa característica, Manoel Correia de Andrade atribui a forma como esse processo foi implantado o aumento considerável da representação da população urbana em relação ao total de habitantes do Nordeste. Pode-se observar que, no decorrer das décadas de 1960 a 1990, a representação do total produzido no setor de serviços aumentou de aproximadamente $47 \%$ para cerca de $69,80 \%$. Ao mesmo tempo, a participação da agricultura perdeu importância relativa, partindo de um patamar de aproximadamente 20\% em 1970, ganhando participação até 1975 , e atingindo o valor de $23 \%$ da produção, mas em seguida perdendo importância chegando ao valor de 10,16\% em 1995. Por fim, a indústria mostrou crescimento, impulsionado pela expansão das usinas, em sua participação até o ano de 1985, atingindo uma taxa de $30,15 \%$ da participação no PIB. Entretanto, devido às políticas econômicas associadas à posição do Governo Federal na época de contenção do processo inflacionário, a indústria nordestina reverteu seu processo de crescimento, e passou até o final do período estudado com perda em sua participação na composição do PIB, chegando em 1995 ao patamar de aproximadamente $20 \%$ do PIB. Quanto ao aumento da importância da indústria, Manoel Correia de Andrade afirma:

“A industrialização porém não foi uma grande absorvedora de mão-deobra não-qualificada ou pouco qualificada, nem impediu que o processo 
de marginalização dos migrantes que vinham para cidade fosse detido, nem que continuasse a haver uma expressiva migração dos trabalhadores rurais para o Sudeste, o Sul e o centro-oeste, até durante os anos sessenta, e para as áreas periféricas e subpovoadas do próprio nordeste, nos anos setenta. Assim ocorreu no Nordeste uma transferência expressiva da população do meio rural para o urbano, numa ocasião em que as cidades não tinham condições de oferecer oportunidade de trabalho aos migrantes, ocasionando a queda da qualidade de vida urbana(...)"(ANDRADE, M: 1993, p.24)

A hipótese de Andrade quanto à alocação da força de trabalho é corroborada pelos dados da distribuição da mão de obra em regiões urbanas, ao analisarmos as duas maiores metrópoles da região. A tabela 17 traz a distribuição percentual das pessoas empregados nos setores de: indústria de transformação, construção civil, comércio, serviços e outras atividades, no período de 1991 a 1998, com periodicidade anual.

Tabela 17 distribuição das Pessoas Economicamente Ativa(PEA) e ocupadas por setor - Unidade = percentual $(\%)$

\begin{tabular}{cccccccccc}
\hline Região & & 1991 & 1992 & 1993 & 1994 & 1995 & 1996 & 1997 & 1998 \\
\hline & Industria de transformação & 11,4533 & 10,5608 & 10,1050 & 9,4150 & 9,1875 & 8,8075 & 8,5975 & 8,4467 \\
Salvador - & Construção civil & 9,1467 & 9,0792 & 8,5892 & 8,9233 & 8,6825 & 8,6258 & 8,1892 & 8,1092 \\
BA & Comércio & 15,1367 & 15,4850 & 15,7858 & 15,9408 & 15,7517 & 15,8500 & 15,6250 & 15,5575 \\
& Serviços & 53,8358 & 54,0383 & 54,6717 & 54,9750 & 56,1117 & 56,1375 & 56,7358 & 57,1842 \\
& Outras atividades & 10,4283 & 10,8358 & 10,8483 & 10,7483 & 10,2683 & 10,5817 & 10,8525 & 10,7017 \\
& Indústria de transformação & 13,4258 & 12,9133 & 12,8706 & 12,0775 & 11,6050 & 11,0575 & 11,0750 & 10,7642 \\
Recife - PE & Construção civil & 6,6392 & 6,4100 & 6,3828 & 6,3625 & 6,4800 & 6,3933 & 6,2100 & 6,6075 \\
& Comércio & 17,5583 & 17,0492 & 17,2575 & 17,9308 & 18,1858 & 18,6883 & 18,4800 & 18,0350 \\
& Serviços & 50,1283 & 51,0225 & 50,7931 & 51,6633 & 52,0042 & 52,2067 & 52,0950 & 52,8792 \\
& Outras atividades & 12,2517 & 12,6092 & 12,6978 & 11,9658 & 11,7208 & 11,6525 & & 11,7150 \\
\hline
\end{tabular}

Fonte: IBGE, Pesquisa Mensal de Emprego jan/1991 a dez/2002

Com a tabela anterior, temos que, em ambas as cidades, o maior setor absorvedor de mão de obra é o de serviços, mostrando representatividade média de 55,4612\% dos empregados em Salvador e 51,5990\% dos empregados em Recife. O segundo ramo que mais emprega é o comércio com representatividade média de $15,6415 \%$ na capital baiana e $17,8981 \%$ na capital pernambucana. Outra informação pertinente que a tabela nos traz é que, no caso da economia urbana nordestina, a indústria de transformação não tem-se mostrado absorvedora de mão de obra. De fato, em ambas as cidades observou-se uma perda de significância da indústria no mercado de trabalho, algo que se encontra em sintonia com a 
interpretação de Andrade, que atribui à indústria a incapacidade de absorver os trabalhadores expulsos do campo.

Assim, o processo de industrialização implantado no nordeste com a expansão das usinas e a criação do setor cloroquímico decorreu da migração de mão de obra qualificada das regiões mais desenvolvidas do país para os centros industriais, que se localizavam na zona urbana do litoral. Com isso, a expectativa de crescimento e geração de empregos causou euforia nas regiões beneficiadas, o que fez com que se formasse um cenário de atração da população das regiões do agreste e do sertão. Essa população, ao chegar à urbe, defrontava-se com uma concorrência que não era capaz de vencer, devido à característica histórica de pouca especialização, terminando por se aglomerar em favelas que resultaram na geração de um novo contingente de problemas urbanos.

A alocação da mão de obra em Manoel Correia de Andrade, com alta concentração das terras e com o atual processo de urbanização descontrolada, é outro dos principais problemas estruturantes que impedem a superação da condição de subdesenvolvimento, o gráfico 10 representa a população total com mais de 16 anos de idade a população ocupada na agropecuária no nordeste durante o período de 1970 e 1995.

Gráfico 10. Evolução da população total do nordeste e população ocupada na agropecuária (habitantes)

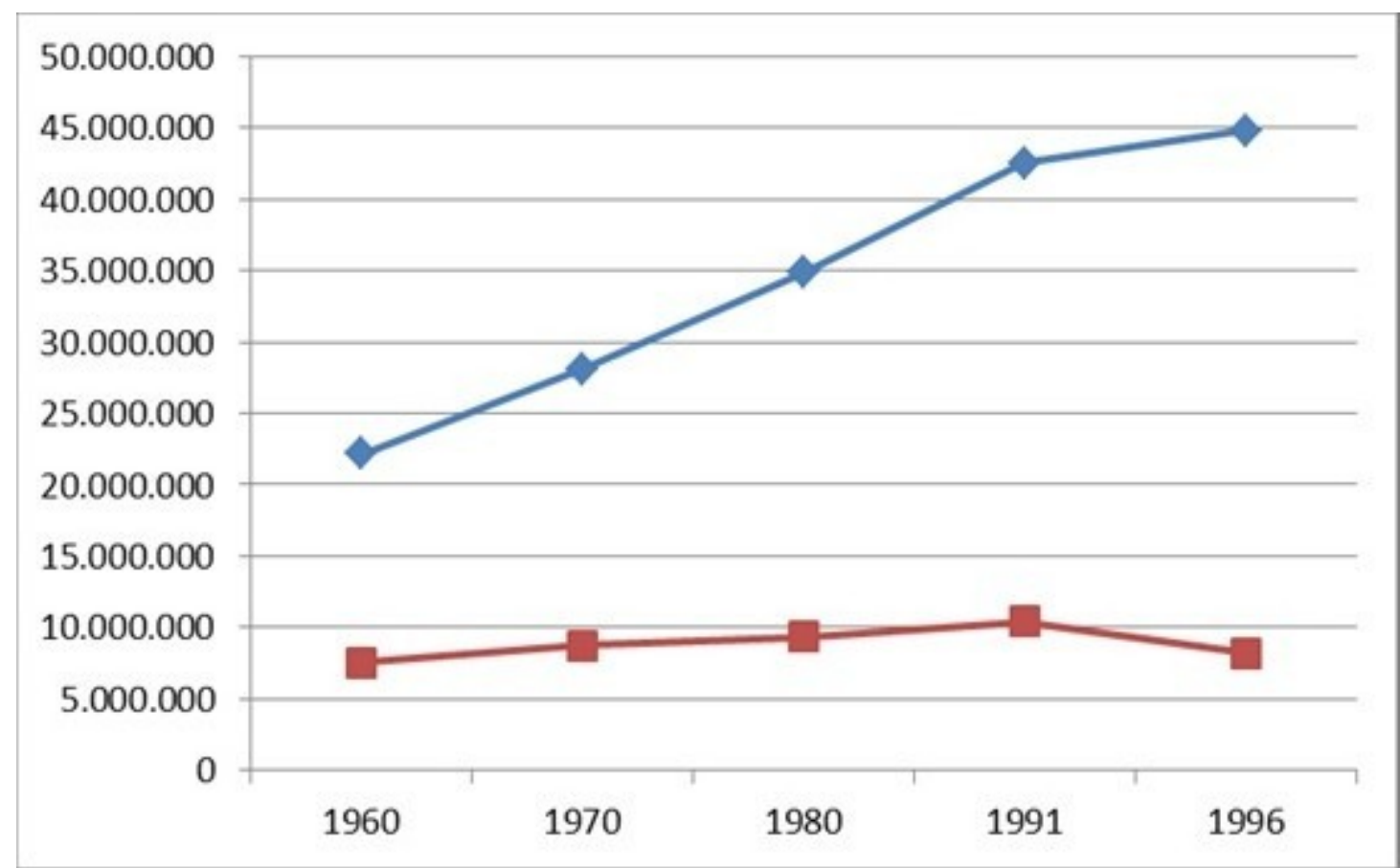

Fonte: IBGE, Censo demográfico 1940-2010. Até 1970 dados extraídos de: Estatísticas do século XX. Rio de Janeiro: IBGE, 2007 no Anuário Estatístico do Brasil, 1981, vol. 42, 1979. 
O gráfico acima mostra como o crescimento a população total do Nordeste se perpetrou no decorrer das décadas de 1970 e 1980, chegando até 1995, saindo de um patamar de 22 milhões de habitantes, ultrapassando a marca de 35 milhões de habitantes em 1985, terminando por se elevar até 44 milhões de habitantes, em 1995. Durante o mesmo período, houve a perda de participação do pessoal empregado na agropecuária, que saiu de uma representação de 31,09\% em 1970 chegando ao nível de 16,13\% em 1995.

Um outro sintoma dos movimentos migratórios de sentido campo-cidade é o crescimento do diferencial relativo entre os valores dos capitais residências das regiões urbanas e rurais, ou seja, o aumento do "gap" dos valores agregados gastos com pagamentos contínuos de alugueis de imóveis urbanos e rurais. $\mathrm{Na}$ tabela 18 , temos os valores absolutos de capitais residenciais, a preços do ano 2000, por categoria da região de origem, assim como a taxa percentual de variação ocorrida entre os anos observados. Foram utilizados os dados para os anos de 1970 a 2000 com periodicidade decenal.

Tabela.18 Valor dos Capitais Residenciais de 1970 a 2000 (unidades= R\$ do 2000) e taxa de variação (\%)

\begin{tabular}{|c|c|c|c|c|c|c|c|}
\hline & 1970 & Variação \% & 1980 & Variação \% & 1991 & Variação \% & 2000 \\
\hline $\begin{array}{l}\text { Capital Residencial Urbano - } \\
\text { Nordeste }\end{array}$ & 38.309 .639 & $90,77 \%$ & 73.083 .565 & $42,11 \%$ & 103.860 .214 & $63,41 \%$ & 169.722 .106 \\
\hline $\begin{array}{l}\text { Capital Residencial Rural - } \\
\text { Nordeste }\end{array}$ & 10.358 .417 & $15,37 \%$ & 11.950 .867 & $-15,53 \%$ & 10.094 .330 & $34,74 \%$ & 13.601 .285 \\
\hline
\end{tabular}

Fonte: Instituto de Pesquisa Econômica Aplicada (IPEA)

Temos, então, que os valores dos capitais residenciais em zonas urbanas sempre se encontraram em valores mais elevados do que os das zonas rurais. Isso já era esperado ao considerar-se a maior densidade populacional das cidades, assim como a maior demanda pelos espaços mais próximos dos centros produtivos. Contudo, mais importante do que as observações individuais é o sentido das variações. Nesse caso, o capital residencial das zonas urbanas expandiu-se de R\$27.951.222 em 1970, para R\$156.120.821, em 2000, em uma variação total de 458,5474\%. Consolidou-se, assim, um aumento do diferencial do custo de habitação, no sentido de encarecer os espaços residenciais das zonas urbanas com relação às zonas rurais no Nordeste.

Paralelamente ao progresso de crescimento populacional, houve um respectivo aumento da esperança de vida dos trabalhadores. Nesse caso, fala-se da ampliação do acesso a melhores condições médicas. O quadro 3 apresenta a evolução da expectativa de vida no Nordeste no período de 1940 a 1991. 
Quadro 3 : evolução da esperança de vida no nordeste, 1940 - 1991

\begin{tabular}{|c|c|}
\hline Período & Esperança de vida(Anos de vida) \\
\hline 1940 & 36,68 \\
\hline 1950 & 38,94 \\
\hline 1960 & 40,98 \\
\hline 1970 & 45,54 \\
\hline 1980 & 58,25 \\
\hline 1991 & 62,88 \\
\hline
\end{tabular}

Fonte: IBGE, Censo demográfico 1940-2010. Até 1970 dados extraídos de: Estatísticas do século XX. Rio de Janeiro: IBGE, 2007 no Anuário Estatístico do Brasil, 1981, vol. 42, 1979.

Entre as décadas de 1940 e 1990, houve um aumento de 71,42 \% da esperança de vida da população nordestina. Na década de 1940 a esperança média de vida era de 36 para 37 anos, aumentando na década de 1950 para 39 anos de idade, e continuando em alta até 1990 atingindo um nível de 63 anos. No entanto, esse avanço pode ter sua causa atribuída a fatores externos ao caráter de desenvolvimento da estrutura social produtiva nordestina, já que, como coloca Manoel Correia de Andrade, essa estrutura é absorvedora de aspectos conjunturais.

O quadro 4 explicita o valor em quilômetros quadrados da superfície ocupada pelos territórios estaduais, suas respectivas populações e divisão da população pelo território abrangido a densidade demográfica no ano de 1986. Essa tabela apresenta o corte temporal identificando a maior densidade demográfica na área litorânea e da mata.

Quadro 4 superfície e população dos estados nordestinos em 1986

\begin{tabular}{|c|c|c|c|}
\hline & Superfície $\left(\mathrm{Km}^{2}\right)$ & População(hab.) & $\begin{array}{c}\text { Densidade } \\
\text { demográfica } \\
\left.\text { (hab. } / \mathrm{Km}^{2}\right)\end{array}$ \\
\hline Maradanhão & 328.663 & 4.490 .400 & 13,6 \\
\hline Piauí & 250.934 & 2.567 .400 & 10,2 \\
\hline Ceará & 148.016 & 6.239 .400 & 42,2 \\
\hline Rio Grande do norte & 53.015 & 2.236 .200 & 42,2 \\
\hline Paraíba & 56.372 & 3.152 .600 & 55,9 \\
\hline Pernambuco & 98.281 & 7.114 .600 & 72,4 \\
\hline Alagoas & 27.731 & 2.342 .300 & 84,5 \\
\hline Sergipe & 21.994 & 1.369 .000 & 62,2 \\
\hline Bahia & 561.026 & 11.304 .400 & 20,1 \\
\hline
\end{tabular}

Fonte: ANDRADE, M: 1993, p.17

A densidade demográfica em meados da década de 1980 mostrava-se mais elevada em estados com maior proporção territorial do litoral e da mata, sendo que, por exemplo, Alagoas, estado com maior parcela proporcional de terras nas áreas litorâneas, possui uma 
densidade demográfica de aproximadamente 84 habitantes por quilômetro quadrado, em 1986. Esse fato também é influenciado pelo processo de urbanização e êxodo rural, tendo em vista que os maiores centros urbanos, como Recife e Salvador, se localizam no litoral. Dessa forma, a urbanização teria suas bases voltadas à concentração nos centros urbanos, criados inicialmente como cidades e transporte, ou escoamento de mercadorias.

Destaca-se o crescente processo de urbanização com o gráfico 11, que demonstra a evolução da taxa percentual da população nordestina que reside dentro dos territórios dos centros urbanos no período entre a década de 1940 e 1990.

Gráfico 11. Nordeste, taxa percentual de urbanização, 1940 - 1991

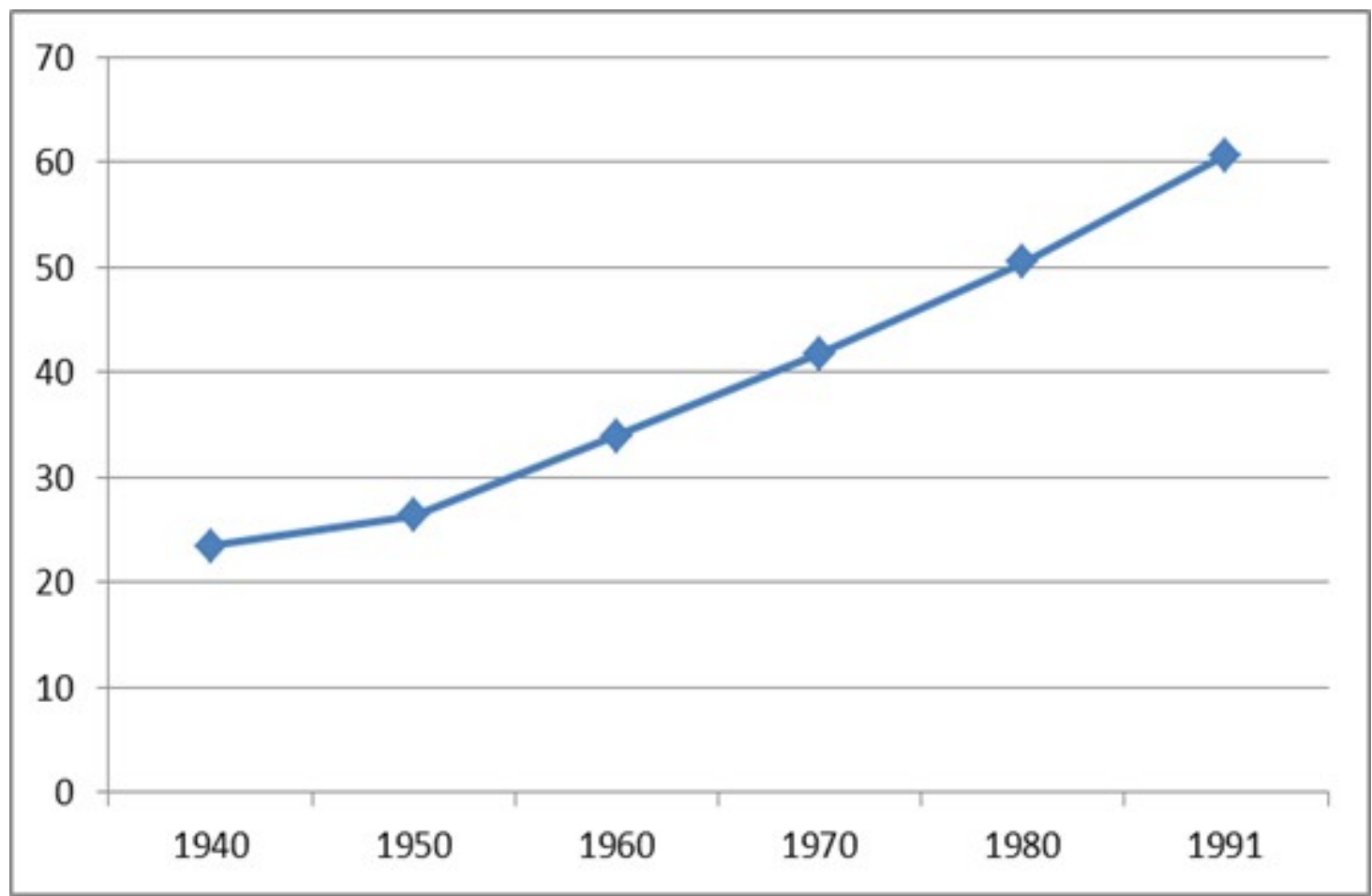

Fonte: IBGE, Censo demográfico 1940-2010. Até 1970 dados extraídos de: Estatísticas do século XX. Rio de Janeiro: IBGE, 2007 no Anuário Estatístico do Brasil, 1981, vol. 42, 1979.

O gráfico 11 mostra uma taxa de urbanização crescente, sendo que na década de 1940 a população residente nos centros urbanos do Nordeste representava $23,42 \%$ da população total. Durante as décadas de 1950, 1960, 1970 e 1980, a taxa de representação elevara-se a patamares respectivamente de 26,$4 ; 33,89 ; 41,81 \%$ e 50,46\%; e chegaria em 1991 ao valor representativo de 60,65\%. Esses valores, associados à perda da importância de pessoal ocupado, como demonstrado no gráfico 11, mostram um cenário coerente com o traçado por Manoel Correia de Andrade na obra O Nordeste e a Questão Regional. Houve um aumento da concentração nas regiões urbanas que resultariam em três problemas sociais que deveriam ser 
controlados, como medidas de desobstrução de barreiras ao desenvolvimento econômico da região. Esses problemas seriam:

1. O êxodo rural forçado pelo medo e vontade de preservação do poder dos proprietários de terras, nesse ponto Manoel Correia afirma que "Isto não ocorre no nordeste onde o campo está se despovoando em consequência da expulsão dos trabalhadores(...)" (ANDRADE.1993)

2. O processo de expansão desordenada das cidades, que geraria aumento da violência, da taxa de desemprego e expansão dos empregos informais

3. "As cidades ficam superpovoadas, as pessoas se marginalizam, por não encontrarem trabalho, se ligam a atividades informais, ou, pior ainda, enveredam pelo roubo e a prostituição. Observa-se então uma queda do padrão arquitetônico e social das cidades. Do ponto de vista arquitetônico surgem os bairros marginais, formados por habitações que não atendem a um mínimo de conforto e higiene, formando favelas que muitas vezes abrigam percentuais muito elevados da população urbana.”(ANDRADE, 1993, p. 53).

É possível afirmar que, dentro do período analisado que abrange um corte histórico das décadas de 1970 a 1990, adotado por englobar parte do tempo referido na obra de Manoel Correia dando ênfase no processo de urbanização, pode-se notar uma sintonia com o que foi explicitado pelo autor como fuga de população aos centros urbanos, processo esse que explica a crescente participação do setor de serviços e do comércio na economia nordestina.

\section{Sentido da Produção Urbana}

Ao elaborar sua análise dos diversos momentos históricos do que viria a ser o Nordeste brasileiro, Manoel Correia em “A Terra e o Homem no Nordeste." põe em ênfase o caráter marginalizante da Urbanização. Partindo de uma premissa de que a modernização das máquinas e a substituição do trabalho levariam a criação de excedente populacional, que na busca por condições de subsistência se veriam alocados nos centros urbanos.

Os centros urbanos do Nordeste, em processo de industrialização, não teriam capacidade de absolver o excedente populacional, criando-se com isso um sistema centrado na produção de bens industrializados voltados a exportação e derivados dos produtos agrícolas, como são os casos das agroindústrias sucroalcooleira, cacaueira e da soja. 
A urbanização é elemento-chave para compreender um aspecto importante da totalidade da obra de Manoel Correia de Andrade, principalmente no que se refere " $A$ Terra $e$ o Homem no Nordeste”, pois o autor passou grande parte de sua vida acrescentando novas ocorrências e desenvolvimentos de conjuntura no corpo de seu objeto de análise. O nordeste, nesses mais de quarenta anos desde a publicação da primeira edição da obra, foi objeto de diversas forças sociais que lhe causaram mudanças conjunturais, mas somente com a visão de quem observou o seu carácter histórico e estrutural, pode se perceber que as mudanças embora significativas não alteraram de forma fundamenta as relações produtiva e estruturas políticas do território nordestino.

Pode-se observar que a urbanização nordestina ocorreu dentro dos moldes estabelecidos pelo território, ou seja, pelas zonas de influência dos agentes políticos econômicos, capaz de controlar as tendências de crescimento e distribuição da renda. Houve com isso, a criação de uma parcela da população que, buscando melhores condições de vida, se encontraram a margem de uma sociedade que não os introduzirá na sua estrutura produtiva. Fazendo com que essa nova população marginalizada buscasse alternativas como os mercados de trabalho informais, perpetuando assim regimes de trabalho de semiescravidão e disseminando-se as favelas e criando uma sociedade à margem do centro urbano nordestino.

A hipótese de Manoel Correia de Andrade quanto a um processo de urbanização marginalizada, está enraizada nas dinâmicas dos territórios. Nela, cada vez menor é a proporção de trabalhadores voltados à agricultura, e maior a representação da população urbana, o que corrobora a hipótese do historiador pernambucano, devido ao fato de que os mercados criados nos centros urbanos dependem de variáveis exógenas, como a dinâmica do mercado nacional, internacional e até, nos setores voltados a atividades de serviços, dos mercados rurais. Assim sendo, a capacidade de inclusão do trabalhador recém-chegado também tende a se limitar também a forças exógenas tornando-se cada vez mais insensível a influxos de trabalhadores, o que aumenta o caráter concentrador de riqueza e socialmente excludente desse modelo.

\section{O Debate sobre Urbanização: Massas Marginalizadas ou Polarização Regional}

A urbanização observada por Manoel Correia de Andrade e analisada em sua obra " $A$ Terra e o Homem no Nordeste" é caracterizada como um processo paralelo à modernização da agropecuária, com investimentos pesados na compra de novo maquinário para a indústria do açúcar, que, por uma questão conjuntural, apresentava uma situação favorável no mercado 
internacional. Com o jargão de "garantir os empregos" das pessoas envolvidas no setor e com o suposto objetivo de "crescimento econômico", várias usinas ampliaram sua produção, estendendo o raio de influência que o setor sucroalcooleiro tinha para com grande parte da sociedade nordestina. É importante ressaltar o processo de modernização, para contextualizar o fenômeno que impulsionou fortemente a urbanização no nordeste, esse sendo o êxodo rural.

O processo de urbanização em si não é algo novo no desenvolvimento das civilizações. De fato, esse é um conceito tão antigo quanto a existência de excedentes agrícolas. Entretanto, é a forma como se dá tal fenômeno nas regiões subdesenvolvidas do nordeste torna a problemática dos movimentos migratórios para as regiões urbanas no nordeste. Esses movimentos se intensificaram nas últimas décadas, devido ao desenvolvimento de uma rede urbana que interliga os grandes centros do litoral ocidental aos menores centros urbanos do agreste e sertão. Manoel correia atribui a aceleração da urbanização a:

“(...) o fenômeno urbano teve grande aceleração, não só pelo crescimento da população das grandes cidades a vários milhões de habitantes como pelo aparecimento de milhares de cidades pequenas e médias a partir do século XIX. E o crescimento destas cidades esta ligado ao desenvolvimento de técnicas agrícolas que permitiram o abastecimento das mesmas em víveres - crescimento da produtividade agrícola por hectare cultivado e por homem-dia empregado como também pelo desenvolvimento dos meios de transporte e comunicação."(ANDRADE, 1974, p. 87)

Para além da aceleração e direção da migração campo-cidade, ainda há uma ausência nos menores centros urbanos de políticas públicas que tratem da organização dos trabalhadores que chegam aos centros, geralmente localizados no Agreste e Sertão, podendo se observar um movimento de urbanização marginalizada, no qual o indivíduo que chega a zona urbana não se integra à economia urbana, majoritariamente representada pelo comércio e pelos serviços, formando-se assim comunidades periféricas. Nesse sentido, o que já vem acontecendo nos maiores centros urbanos do litoral, passa a ser reproduzido nos menores centros urbanos do Agreste e Sertão.

A reprodução do padrão de urbanização do litoral para os centros do Agreste e do Sertão representa, segundo Manoel Correia, uma forma de domínio que se transmite com maior velocidade, conforme se desenvolve a rede urbana, com melhores vias de transporte e 
melhores meios de comunicação. A mobilidade do principal fator produtivo, o trabalho, considerando que a produtividade da terra se encontra constante, permite aos maiores centros domínio sobre as atividades dos centros menores, que visam a reprodução do padrão de vida dos centros maiores e mais antigos. Assim, Manoel Correia caracteriza esse processo de transmissão do núcleo para a periferia da seguinte maneira:

“(...) O núcleo(da rede urbana) não permanece sempre na mesma região, não é comandado sempre pela mesma cidade. Em determinado momento histórico, uma porção do país que dispõe de condições naturais favoráveis, de acesso fácil ao mercado e é capaz de produzir mercadoria demandada pelo mercado internacional se dinamiza, progride, e passa a tutelar as regiões vizinhas, ora despovoada, que passam a ser colonizadas, ora já povoadas mas com uma economia tradicional estática, que passa a ser dominada pelo núcleo que passa a comandar a vida econômica." (ANDRADE, 1974, p. 196)

A dinâmica das zonas urbanas de maior e menor porte tende a oscilar conjunturalmente, sendo que as estruturas produtivas, em suas permanências, alteram-se através de choques externos, sejam esses causados por vantagens naturais ou alterações no mercado internacional. O importante a se considerar, no entanto, é que independente dos fatores exógenos, as redes urbanas e os processos de urbanização que as formam, tendem a criar um território de dominância para além da dicotomia dos territórios do setor sucroalcooleiro e das atividades complementares. Enfatiza-se, assim, a importância das zonas urbanas, que servem como absorvedoras da população que não seria alocada nas atividades primárias ou complementares. Quanto à função das zonas urbanas Manoel Correia assim dispõe:

“A análise da importância dos centros urbanos implica, além do conhecimento da evolução histórica e econômica, no estudo da interação rural-urbana expressa pela inter-relação existente entre as funções urbanas de atendimento à população do meio rural e as atividades rurais geradoras da produção, dirigida diretamente para os centros locais ou usando estes como ponto de comercialização e distribuição dos produtos.”(ANDRADE, 1988, p. 554)

Considerando a importância das redes urbanas como absorvedoras de população rural, cabe considerar agora a forma do processo de urbanização, de crescimento da parcela da população em área urbana. No Nordeste isso em grande parte supriu um crescimento nas 
atividades secundária e terciaria, como, por exemplo o turismo, que "é a outra grande atividade criadora de divisas para o Nordeste"(ANDRADE, 2011). Entretanto, o crescimento das atividades ditas secundárias e terciárias não foi suficiente para suprir a demanda por empregos nos centros urbanos em crescimento, e observou-se com isso a criação de um novo território. Esse território seria composto pela população que ficaria à margem do sistema urbano, formando assim um sistema marginalizado. Quanto a essa urbanização crescente o autor assim expõe:

"É forçoso reconhecer que o crescimento urbano foi bastante acentuado no período de 1980/95, fazendo com que as três principais cidades da região - Salvador, Fortaleza e Recife - ultrapassassem, isoladamente, em suas áreas metropolitanas, os três milhões de habitantes e que muitas das cidades de menor porte atingissem mais de um milhão de habitantes, este crescimento, porém, se deu sem que as atividades secundárias e terciárias fossem capazes de absorver este aumento populacional, o que acarretou a proliferação de favelas e mocambos, a queda do nível de vida, de alimentação, de educação e de saúde da população, a difusão do uso das drogas, sobretudo entre adolescentes, o crescimento da prostituição e a insegurança dominante nas ruas." (ANDRADE. M: 2011(1963) p. 249 e 250)

Ao observar a urbanização ocorrida durante nas décadas de 1950. 1960. 1970 e 1980 Manoel Correia de Andrade expõe um cenário onde as tentativas de mudança, ou de superação do subdesenvolvimento foram distorcidas, para manter uma estrutura arcaica de relações de produção, de modo que os agentes econômicos e políticos criaram um território com influência capaz de modificar forças de dinamização da economia, como as tentativas de superação empregadas pela SUDENE, e transformá-las em forças de crescimento com desigualdade.

Fez-se, então, a utilização de dados de crescimento econômico um mecanismo para justificar as mudanças que levariam a um fluxo migratório direcionado aos centros urbanos dos litorais do Nordeste, assim como a outros centros que supostamente teriam a capacidade de integrar essa população de origem rural às cadeias produtivas industriais, fornecendo assim um padrão de vida mais elevado. Essa forma de mascarar a realidade da expulsão das massas trabalhadoras do campo, parece em sintonia com o que Milton Santos aponta: 
"Parece-nos, entretanto, perigoso conferir a simples números um valor autônomo; na realidade, os números são a expressão de um estado de coisas comandado por um mecanismo. Se desejarmos conhecer seu real significado, precisamos analisá-los paralelamente à análise dos fatos que tais números supõem representar. Ou seja, faz-se necessário que tais análises levem em conta categorias de tempo e espaço.”(SANTOS, 2012, p.14)

O estudo da urbanização no Nordeste teria que partir do contexto histórico e social para determinar de que forma a sociedade tratou as mudanças da composição das populações rural e urbana, pois esses contextos, de concentração dos meios produtivos nas mãos dos herdeiros de uma oligarquia arcaica colonial levam à redução da capacidade que a indústria teria de absorver o excedente de mão de obra no mercado de trabalho, e se satisfaria com a alocação desse excedente em atividades informais e serviços não essenciais ao funcionamento das atividades indústrias e modernas, disseminando com isso um estado de miséria.

Durante o desenvolvimento da economia nordestina nos últimos cinco séculos, as mudanças na forma da estrutura social de produção do Nordeste têm ocorrido geralmente de maneira conjuntural, de forma que somente se destaca de maneira acentuada a ampliação do trabalho assalariado decorrido entre o final do século XIX e inicio do século XX, como elemento "novo" e "distinto" na paisagem. Entretanto, essa mudança na estrutura como um todo foi realizada de forma a manter as bases de dependência intactas, e teria caráter reacionário a uma tendência que não somente vinha doméstica, mas externamente, com as crescentes dificuldades impostas ao trafego negreiro e à escravidão em massa da mão de obra. Sobre essa estrutura social reacionária e perpetuada no tempo Manoel Correia de Andrade explicita:

"Ao se analisar as estruturas sócias nordestinas torna-se difícil enquadrá-las, com uma certa rigidez, nos padrões clássicos marxistas ou weberianos."( ANDRADE, M: 1993, p.25)

Esse fator de rigidez das estruturas sociais é um dos pontos de estrangulamento do desenvolvimento econômico nordestino e faz-se necessária, ainda hoje, a intervenção do Estado, na forma de reforma agrária e inclusão social que dê as classes menos favorecidas a oportunidade de superação de sua condição de dependência, para que se possa realizar a quebra do ciclo de perpetuação do subdesenvolvimento caracterizado por Manoel Correia de Andrade. 


\section{A Teoria dos Polos de Crescimento: Cidades que Moldam Regiões.}

A teoria dos polos de crescimento elaborada por François Perroux, permitiu a elaboração da interpretação da urbanização como decorrente de um processo centralizador, iniciado e moldado por polos individuais, interligados de crescimento econômico. Andrade utilizaria tal teoria para elaborar um forma metodológica de se observar as mudanças estruturais que transpareciam no Brasil na década de 1970, apontando como o desenvolvimento de setores industriais como fatores chaves para entender o crescimento das cidades e os deslocamentos das regiões campesinas para as regiões urbanas (ANDRADE, 1974).

Partindo de um modelo econômico estático, no qual as proporções entre o crescimento econômico e o crescimento populacional são equivalentes e constantes, em que a relação dos fluxos de bens de consumo e de produção são também constantes, onde a propensão a consumir e a poupar, o coeficiente de produtividade e a jornada de trabalho são variáveis constantes também, temos que o pólo de crescimento viria a se formar por quaisquer ações exógenas ao modelo que criassem vantagens ou desvantagens dentre as diversas indústrias contempladas pelo modelo. Perroux aponta para o surgimento de tais pólos como:

"o fato, grosseiro, mas sólido, é que: o crescimento não aparece em todos os lugares ao mesmo tempo; manifesta-se em pontos ou polos de crescimento, com intensidades variadas; Ele se espalha por vários canais e com efeitos finais variados para a economia como um todo.” (PERROUX, 1991, p. 178) ${ }^{48}$

O efeito de dispersão dos estímulos ao crescimento gera o fenômeno social e econômico de centralização dos fatores produtivos industriais, ou pelo menos, das competências administrativas com poder de tomada de decisão quanto a alocação dos fatores produtivos, tal centralização reflete-se no surgimento de centros urbanos, indústriais e administrativos. Exemplos desses pólos são as cidades de São Paulo e a Brasília, onde a primeira é o maior centro produtor industrial e a segunda é o centro do poder executivo federal. Sobre a formação de tais tipos de cidades, Milton Santos explica:

“Com efeito, a cidade é o lugar privilegiado do impacto das modernizações, já que estas não se instalam cegamente, mas nos

48 No original: le fait, grossier mais solide, est celui-ci: la croissance n'apparaît pas partout à la fois ; elle se manifeste en des points ou pôles de croissance, avec des intensités variables ; elle se répand par divers canaux et avec des effets terminaux variables pour l'ensemble de l'économie. 
pontos do espaço que oferecem uma rentabilidade máxima. O processo é velho mas agravou-se recentemente. Por consequência, procurar as explicações e os remédios a partir do próprio problema urbano, significa simplesmente lutar contra sintomas do mal sem procurar suas causas.” (SANTOS, 1978, p. 18)

Nas economias capitalistas modernas, esse pólos tenderam a surgir condicionados pelo desenvolvimento das indústrias as quais Perroux denominou de "motrizes". Essas foram, por diversos motivos específicos, capazes de concentrar capital, gerar uma dinâmica inovativa diferenciada, alterando os coeficientes de produtividade dos fatores econômicos capital e trabalho perante as demais atividades produtivas. Andrade se diferencia de Perroux quando adapta a teoria para a realidade brasileira, rompendo com a noção de que a centralidade deva se dar em uma cidade cujas raízes de seu crescimento estejam ligadas ao crescimento industrial. No caso brasileiro faz-se necessário ampliar o conceito de pólo de crescimento das “cidades que apresentam uma indústria geradora e uma área para ela polarizada em função desta indústria, mas todas as cidades que têm poder de centralidade, isto é todos os centros regionais e sub-regionais. "(ANDRADE, 1974, p. 16)

Conforme formam-se os polos de crescimento, se alastram as zonas de influência, ou os territórios nos quais, das zonas rurais, passam a fazer parte os fluxos de bens produtivos e de consumo estabelecidos pelos centros industriais. Na medida em que se consolida a economia urbana, no sentido de que a produção essencial do sistema passa a ser aquela gerada nas cidades, criam-se redes urbanas de forma hierárquica, com os principais centros polarizadores. Estes, que em um momento eram os únicos centros de controle, passam a criar pólos auxiliares ou intermediários para controlar maiores extensões do espaço. Sobre esse fenômeno, Manoel Correia aponta:

"Daí o surgimento de uma série de entrepostos e formação de uma autêntica rede urbana, em que os centros menores, como satélites, giram em torno dos centros maiores, fornecendo aos mesmos os produtos que eles necessitam e recebendo em retorno aqueles que lhes são necessário. Surge, assim, com a civilização, com o desenvolvimento, uma rede urbana em que os centros maiores funcionam como se fossem grandes pólos em torno dos quais giram polos de menor grandeza, os quais, por sua vez, funcionam como 
polos de centros secundários, formando escalas mais ou menos numerosas.” ANDRADE,1974, p. 87)

A formação de regiões urbanas implica, no surgimento de um diferencial entre as regiões no qual há um elemento centralizador, no caso de Perroux, a indústria motriz. No caso de Andrade, este seria uma indústria ou setores administrativos dos fatores econômicos. A partir da formação dos pólos de crescimento e das regiões urbanas como zonas de influência de tais pólos, cria-se uma relação comercial entre as regiões, cada qual tendo suas funções determinadas pelo centros administrativos, localizados nas cidades. Sobre as relações comerciais entre os pólos de crescimento e as regiões rurais Andrade explica:

“A ideia da região polarizada, ao contrário, resulta da observação da interdependência existente entre várias áreas, às vêzes pertencentes a regiões homogêneas diversas, devido à irradiação da influência comercial das aglomerações urbanas. O poder de atração que uma cidade exerce em torno da área que a cerca, consequente das transações comerciais que realiza com as áreas rurais, provoca a formação de áreas de influência e, em consequências regiões polarizadas."(ANDRADE, 1970, P. 44)

Há uma diferença entre pólos de crescimento e desenvolvimento. Para que uma atividade industrial crescente forme um pólo de desenvolvimento, é preciso criar uma dinâmica de difusão dos padrões tecnológicos e organizacionais da indústria crescente para os demais aspectos da economia. Dessa forma, é de se esperar que um pólo de crescimento anteceda a formação de um pólo de desenvolvimento. Perroux define o pólo de desenvolvimento como: "Uma unidade simples ou complexa, uma empresa, uma indústria uma combinação de indústrias - que comanda outras unidades, com as quais está em relação de treinamento. "(PERROUX, 1991, P. 202) $)^{49}$

Andrade adapta novamente a teoria dos pólos de crescimento ao realizar a critica à noção de que pólos de crescimento, quando em seu estágio de difusão, tendam a se transformarem em pólos de desenvolvimento, principalmente ao que se trata da configuração dos pólos industriais urbanos. Manoel Correia aponta que é possível criar uma relação de troca desigual entre as regiões polarizadas, causando impactos negativos sobre as formas de organização social e econômica nas zonas rurais, mantendo, devido à estrutura de controle

49 No original: Une unité simple ou complexe, une entreprise, une industrie - une combinaison d'industries est motrice quand elle sur d'autres unités, avec qui elle est en relations, des effets d'entraînements. 
administrativo e político, uma dinâmica exploratória das regiões não centralizadas. Assim, Andrade aponta que:

“(...) $\mathrm{Na}$ realidade, estes centros polarizadores nem sempre promovem o desenvolvimento da região para eles centralizada, de vez que em alguns casos, no dos polos de desenvolvimento, eles apenas drenam, sem irrigar, isto é, eles estimulam os fluxos da região para o polo e não compensam a região com os refluxos."(ANDRADE, 1974, p.11)

Parece proceder que mudanças de caráter conjuntural e produtivas nem sempre levam a superações de elementos sociais e econômicos de uma economia subdesenvolvida, tais mudanças podem, de fato, levar a um estado de aumentos generalizados dos coeficientes de produtividade em diversos setores sem que haja alterações nas formas de distribuição de renda e na estrutura de poder administrativo, perpetuando assim elementos arcaicos de um sistema produtivo precedente e limitador. Santos ao observar a perpetuação da pobreza em sociedades em processo de industrialização aponta que:

“(...) diante da realidade, que está sob nossos olhos, não se pode pensar em crescimento que não seja acompanhado por transformações estruturais frequentemente profundas, mas esse crescimento, considerado como uma condição prévia, termina por se tornar um obstaculo ao desenvolvimento "humano" devido aos bloqueios de estruturas que ele provoca por toda parte.” (SANTOS, 1978, p.21)

Assim, a influência da teoria dos pólos de crescimento sobre a análise de Manoel Correia de Andrade, quanto ao processo de urbanização, pode ser associada ao caráter centralizador e polarizador que as cidades tomaram na formação da dinâmica da troca entre as regiões rurais e urbanas no Brasil. Andrade estende a abrangência da teoria, ao abrir as capacidades centralizadoras das cidades a sua função administrativa e não somente ao seu caráter industrializador. No que trata da região do Nordeste, Andrade expõe, em sua forma de ver os pólos de crescimento, que cidades como Recife, João Pessoa, Fortaleza e Salvador, moldaram em seu processo de crescimento uma estrutura de controle administrativo que precedeu formação de unidades indústrias da região(ANDRADE, 1974).

\section{A Teoria das Massas Marginais}

No sistema econômico capitalista há sempre uma parcela da população em busca de emprego que lhe proporcione os meios de subsistência e prosperidade. As explicações e 
justificativas para a existência dessa força de trabalho desocupada foram o foco de muitos debates na ciência econômica, com a elaboração de modelos econômicos clássicos, que atribuem um caráter temporário a tal desocupação, caraterizando a forma de desemprego sofrida por essa população como um "desemprego friccional", ou sejo, um contingente de trabalhadores que estão em busca de emprego, dadas as mudanças momentâneas do mercado em concorrência perfeita. Tal noção elimina teoricamente a possibilidade de uma parcela populacional que esteja sempre em busca de emprego mas que não seja alocada pelo mercado, dessa forma, não haveria a possibilidade de "desemprego involuntário".

Na segunda metade do século XIX, Karl Marx na sessão sobre "produção progressiva de uma superpopulação relativa ou exército industrial de reserva" de "O Capital: Crítica da Economia política" forne uma explicação a existência constante dessa parcela da população desempregada, o Capital em seu processo de acumulação passaria a reduzir a quantidade do componente variável, aumentando magnitude do componente constante de sua composição orgânica (MARX, 1996). A parcela da população desempregada seria um fenômeno sistemático do desenvolvimento das sociedades capitalista. Dessa maneira, Marx explica que:

“(...) Se uma população trabalhadora excedente é produto necessário da acumulação ou do desenvolvimento da riqueza com base no capitalismo, essa superpopulação torna-se, por sua vez, a alavanca da acumulação capitalista. Ela constitui um exército industrial de reserva disponível, que pertence ao capital de maneira tão absoluta, como se ele tivesse criado à sua própria custa. Ela proporciona às suas mutáveis necessidades de valorização o material humano sempre pronto para ser explorado, independente dos limites do verdadeiro acréscimo populacional.” (MARX, 1996, p. 261 e 262)

No caso específico do Nordeste, Manoel Correia de Andrade atribuiria a marginalização da população um aspecto reflexivo de um processo de expulsão da força de trabalho do campo, dada a modernização dos estabelecimentos agrícolas por programas como o POLONORDESTE de 1974. Os trabalhadores se deslocaram para os centros urbanos, onde enfrentariam a exclusão social, criando-se com isso as comunidades periféricas nas zonas urbanas. Essas comunidades funcionariam excluídas da dinâmica de crescimento dos setores industriais, encontrando trabalho no setor de serviços e no mercado de trabalho informal. Sobre tal processo, Andrade discorre:

“Com a construção de estradas asfaltadas cortando a região nordestina em todas as direções, grandes grupos econômicos do sudeste e do 
próprio Nordeste vêm adquirindo pequenas posses dos antigos ocupantes ou ocupando áreas de matas e implantando projetos agroindustriais subsidiados pelo FINOR(Fundo de investimento do Nordeste), após aprovação pelas agências de desenvolvimento. Geralmente estas empresas, ao iniciarem as suas atividades utilizando o fogo e máquinas agrícolas pesadas, destroem a vegetação natural e expulsam os ocupantes para as cidades e povoações, criando grande impacto ecológico pela destruição da fauna e da flora e pela aceleração do processo erosivo, em face da retirada da proteção dos solos. Os subsídios recebidos compensam os investimentos feitos e ate 'os baixos rendimentos dos empreendimentos, ao mesmo tempo em que se desestrutura uma sociedade tradicionalmente organizada sem que se ofereça à mesma opção de reorganização sócio-econômica que preservem as condições mínimas de sua qualidade de vida. Tiram a população da pobreza e lançam na miséria, na prostituição, no roubo e na mendicância.” (ANDRADE, 1998, p.219 e 220)

É do conceito de "exército industrial de reserva" que José Nun parte na elaboração de sua teoria das "massas marginais". Partindo dos desdobramentos do desenvolvimento capitalistas em países do terceiro mundo no século $\mathrm{XX}$, e percebendo a diferenciação entre seguimentos da superpopulação, Nun busca aprofundar explicação fornecida por Marx sobre a composição das superpopulações em suas parcelas funcionais e desfuncionais para a acumulação do capital. Nun inicia seu estudo indicando que:

"Nesse sentido, o materialismo histórico constituirá o universo do meu discurso. Com o relativo privilégio que encerra um século de distância, tentarei mostrar que a releitura de alguns textos de Marx - às vezes não plenamente conscientes de si mesmos - fornece os primeiros elementos necessários para um florescimento produtivo de nosso assunto. Mais especificamente, pretendo estruturar a noção de "massa marginal" a partir de uma crítica à assimilação atual entre as categorias de "superpopulação relativa" e "exército industrial de reserva", apontando as vantagens derivadas dessas precisões teóricas. (NUN, 2001, p. 36)

50 No original:En este sentido, el materialismo histórico constituirá el universo de mi discurso. Con el privilegio relativo que ortoga un siglo de distancia, procuraré mostrar que la relectura de algunos textos de Marx - a veces no totalmente conscientes de si mismos - proporciona los primeros elementos necesarios 
Para Nun, o conceito de massa marginal estaria dentro da noção ampla de superpopulação relativa, sendo que essa seria formada por uma componente desfuncional ligado diretamente à sistemática do capitalismo, relegando parte da força de trabalho a um estado de suspensão dentro da dinâmica produtiva industrial. Entretanto, teríamos também uma nova forma de marginalização da sociedade, que faria parte, conceitualmente, do exército industrial de reserva, mas que não seria contemplada no processo de acumulação industrial em nenhum momento, constituindo parcela permanente do exército industrial de reserva. A partir dessa diferenciação entre os componentes da superpopulação, Nun conceitua:

"Eu chamarei de "massa marginal" a essa parte afuncional ou disfuncional da superpopulação relativa. Portanto, esse conceito - o mesmo do exército industrial de reserva - situa-se no nível das relações estabelecidas entre a população excedente e o setor produtivo hegemônico. A categoria implica, portanto, uma dupla referência ao sistema que, por um lado, gera esse excedente e, portanto, não exige que ele continue funcionando." (NUN, 2001 p. 87) ${ }^{51}$

As massas marginais se referem a parte da "superpopulação relativa" que seriam reassimiladas intermitentemente pelo mercado de trabalho. Dessa form, Nun está se referindo a uma população que faz parte da sistemática de alocação do fator trabalho das economias capitalistas. Comparando o termo massas marginais como "população marginalizada", que Manoel Correia identifica como “Assim ocorreu no Nordeste uma transferência expressiva da população do meio rural para o urbano, numa ocasião em que as cidades não tinham condições de oferecer oportunidade de trabalho aos migrantes, ocasionando a queda da qualidade de vida urbana"(ANDRADE, 1993, p.24). Ao tratar da população recém-chegada nas cidades como um exército de trabalhadores expulsos do campo tem-se, então, uma concepção de marginalização pelo êxodo rural que, na zona rural atribuí a essa população um caráter disfuncional.

Outra interpretação das mudanças na composição campo-cidade, foi a de Fernando Henrique Cardoso, que em sua obra "Mudanças Sociais na América Latina", aponta que a

para un plateo fructífero de nuestro asunto. Más concretamente, me propongo estructurar la noción de "masa marginal" a partir de una crítica a la asimilación corriente entre las categórias de "superpopulación relativa" y de "ejército industrial de reserva", señalando las vantajas que derivan de estas precisiones teóricas.

51 No original: Llmaré "masa marginal” a essa parte afuncional ou disfuncional de la superpopulação relativa. Por lo tanto, este concepto - lo mismo que el de ejército industrial de reserva - se sitúa a nivel de las relaciones que se establecen entre la población sobrante y el sector productivo hegemónico. La categoria implica así una doble referencia al sistema que, por un lado, genera este excedente y, por lo outro, no precisa de él para seguir funcionando. 
formação das "sociedades de massa urbanas" estaria ligada ao crescimento e desenvolvimento das atividades industriais, em que a criação de uma burguesia industrial controladora dos meios de produção provocaria a "mobilidade" social sem "integração" no âmbito políticopartidário e social. Ou seja, teríamos a formação de uma massa populacional sem representação política, e que estaria à mercê dos mandos e desmandos da nova burguesia industrial nas cidades e das sociedades tradicionais rurais.

Para Cardoso, essa falta de integração seria um fenômeno positivo na reorganização social, contanto que ocorresse no sentido de criar um estado de inquietação social capaz de gerar pressões sobre as classes dominantes e, com isso, moldar as tendências de transformação e formação das sociedades de massa. Para tanto, não poderia haver representação partidária das grandes massas urbanas. De fato, nas concepções de Cardoso, um partido político que visasse a representar esse tipo de sociedade, tenderia somente a diminuir o grau de pressão sobre os donos dos meios de produção. Ele assim discorre:

“(...) Os impulsos de reorganização social têm maiores chances de êxito no sentido de modificações profundas na estrutura de poder, e, correlatamente, de alterações na correlação de forças das classes sociais, exatamente quando é possível somar às inquietações a "mobilização" crescente das massas urbanas sem correspondente “integração" destas camadas no jogo político-partidário estatal-legal. Inversamente, quando as massas urbanas podem realizar seus anseios de progresso material e exprimir dentro da ordem estabelecida seu ponto de vista no que diz respeito ao processo político geral (pela organização, por exemplo, de partidos populares-nacionalistas) e podem expor suas reivindicações sobre as condições de trabalho (através de sindicatos reconhecidos como legítimos pela sociedade global) elas atuarão como fator de entorpecimento diante das pressões sobre a ordem sociais formadas a partir dos núcleos dinâmicos não integrados à sociedade urbana de massas.”(CARDOSO, 1969, P. 151)

Tal análise parece falhar ao ignorar qualquer dissociação dentro da composição da própria sociedade em massa, Marx e Engels já definiam uma diferenciação entre uma massa proletária cujos interesses seriam comprados para garantir seu estado de bem-estar essa seria o "lumpemproletariado" que teria seus interesses em sintonia com os mandos das classes dominantes (MARX, 2005). Além disso, Cardoso falha ao elaborar um processo de mudanças lastreado em saltos ou episódios pontuais de revoltas de inquietações e por isso não admite 
um processo de representação político-partidário capaz de realizar mudanças nas organizações sociais progressivas, através de representações integradas dos partidos populares-nacionalistas perante as classes dominantes. Dessa forma, a integração serviria como meio de pressão organizada, ao contrário da pressão esporádica e caótica proposta pelo autor.

\section{Algumas Considerações Sobre a Urbanização e seu Debate .}

Observando as mudanças demográficas que aconteceram nas décadas de 1970 a 1990, é possível estabelecer um quadro de consolidação de uma nova composição da população nordestina, em que, as regiões urbanas tornaram-se dominantes. O crescimento das cidades, subsidiado pelo crescimento do setor de serviços e comércio foi visto por Andrade como um resultado do surgimento de polos administrativos e comerciais para os quais foram direcionados uma população que, quando expulsa do campo por razões de "modernização" do mercado de trabalho, teriam encontrado nas cidades do litoral oriental e setentrional, meios de subsistência em comunidades marginalizadas.

O debate sobre as formas e consequências da urbanização tem em comum, primeiro a formação de territórios específicos de organização socioeconômica, seja na teoria dos polos de crescimento ou na teoria das massas marginalizadas, transparece a formação de uma relação de dependência entre duas regiões, para os teóricos dos polos de crescimento a divisão territorial se daria pelo surgimento dos deferenciais de coeficientes produtivos seguidos pela aparição dos setores industriais centralizadores. Já para os teóricos das massas marginalizadas haveria a divisão territorial em função do aparecimento de segmentos constantes do exército industrial de reserva nos conformes da teoria marxista.

A hipótese de Manoel Correia de Andrade quanto a urbanização é corroborada ao se observar a evolução da significância das populações urbanas, da disseminação dos centros urbanos, da divisão setorial do mercado de trabalho da região e dos movimento populacionais intra e inter-regionais. Houve no período de 1973 à 1998 a consolidação de diversas economias urbanas centralizadoras, com mercado de trabalho intenso em serviço e comércio e absorvedora de uma força de trabalho desamparada e fugida do campo. 


\section{Capítulo 4. Manoel Correia de Andrade: A SUDENE e o Subdesenvolvimento Regional nas Décadas de 1960, 1970 e 1980.}

\section{Introdução}

Aqui, se examina o papel da SUDENE no subdesenvolvimento nordestino, em sua atuação política e suas iniciativas desenvolvimentistas. A perspectiva de Manoel Correia de Andrade, como se demonstra, não apenas mostra um exame acurado e crítico da atuação da Superintendência, desde sua formação e primeiros movimentos institucionais, mas também o eco que essa perspectiva encontra em outros examinadores da questão, alguns deles bastante próximos e atuantes do órgão.

Este capítulo se encontra dividido em cinco sessões, a saber:

(1) Uma breve introdução ao assunto;

(2) Manoel Correia de Andrade e a SUDENE;

(3) Uma análise comparativa das visões de Manoel Correia de Andrade, Caio Prado Júnior, Celso Furtado e Francisco de Oliveira sobre o papel do Estado;

(4) Avaliação crítica dos Planos Diretores da SUDENE e da interpretação de Manoel Correia de Andrade e, por fim,

(5) Algumas considerações.

\section{A Criação da SUDENE}

A SUDENE foi instituída pela lei 3.692, de 15 de dezembro de 1959. À sua frente, encontrava-se o então diretor do Banco Nacional do Desenvolvimento (BNDE), Celso Furtado, que naquele mesmo ano publicaria Formação Econômica do Brasil. Na liderança da SUDENE, Furtado viria a tentar colocar em prática sua proposta de tentativa de superação do subdesenvolvimento do Nordeste, presente em A Operação Nordeste (1959) e em Desenvolvimento e Subdesenvolvimento (1962). Algumas considerações sobre isso podem ser encontradas na própria obra autobiográfica de Celso Furtado, em particular no volume sobre a SUDENE, A Fantasia Organizada, de 1985. Algo que, em 1963, na primeira edição da $A$ Terra e o Homem no Nordeste, Manoel Correia apontaria como uma possível força de mudança das estruturas socioeconômicas da região. 
Furtado definiria dois objetivos primários da SUDENE: (I) ser o agente de elaboração e execução das políticas de desenvolvimento para o Nordeste e (II) ser instrumento de modificação das estruturas administrativas na busca de novos objetivos ainda não estabelecidos. O primeiro teria repercussão direta sobre as formas de produção no Nordeste. Já o segundo seria estabelecido com a intenção de atribuir ao mecanismo governamental certa flexibilidade sem que para isso fosse necessário a realização de reformar administrativas, as quais, segundo Furtado, "a nada conduzem".

Outro membro de relevância do quadro inicial da SUDENE foi Francisco de Oliveira, sociólogo pernambucano que em sua obra Elegia Para uma Re(li)gião (2008) explicaria que a contribuição da Manoel Correia divergiria de sua concepção na medida que esse: “(...)Partiu do meio-físico para o econômico político,(...)” (2008, p. 41). Dessa forma, e em certa medida, as políticas debatidas dentro da SUDENE tenderiam a divergir da concepção de Nordeste elaborada por Manoel Correia de Andrade.

Em 1966, seriam publicados, em caráter retroativo, os planos da SUDENE de 1961, 1963 e 1966, com o intuito de mostrar a evolução da estratégia de desenvolvimento do órgão. Os dois primeiros planos se caracterizam pela geração de conhecimento quanto aos recursos e problemas enfrentados na região, tendo também iniciado os investimentos em infraestrutura básica que, em maior ou menor grau, permeariam as ações da SUDENE. Em muitos aspectos, esses planos tomam a noção, mesmo que não declaradamente, disseminada na época de que o Nordeste seria uma "região problema", devido à seca. Tal forma de ver o Nordeste viria a ser um dos principais dilemas que as obras de Manoel Correia de Andrade tentariam refutar. Andrade interpretava os principais bloqueios da economia nordestina como sendo problemas da estrutura social e do papel que o trabalhador teria na sua composição, assemelhando-se assim a Caio Prado Júnior, quando esse define o principal entrave ao desenvolvimento como sendo um "problema humano". Isso seria uma herança histórica das estruturas produtivas que condicionam as mudanças socioeconômicas ocorridas no Nordeste.

Os técnicos da SUDENE, em consonância com a percepção generalizada da época, partiam da prerrogativa de que haveria um atraso da economia nordestina em relação às regiões desenvolvidas do país:

“O Nordeste, onde vive um terço da população do país, não está acompanhando o desenvolvimento da economia nacional, razão pela qual se aprofunda, dia a dia, um desequilíbrio de caráter regional. (SUDENE, p. 13, 1966) 
A solução da SUDENE para a "região problema" seria a formação de um ambiente econômico capaz de iniciar um processo de transformações econômicas que levassem ao surgimento de um setor com o um ritmo de crescimento econômico elevado e autônomo, eliminando assim os elementos ainda existentes do subdesenvolvimento. Segundo Manoel Correia,

"O Setor industrial foi preocupação básica da SUDENE, de vez que na época de sua criação dominava a ideia de que a industrialização era chave do desenvolvimento. Ela realizou estudos sobre as indústrias existentes, considerando-as tradicionais, e procurou estimular as empresas viáveis economicamente a modernizarem e ampliarem os seus estabelecimentos;" (ANDRADE, 1993, p. 44)

As primeiras diretrizes de ação refletiriam esse diferencial regional através do primeiro Plano Diretor, de 1961, o qual daria início a um processo contínuo de impulso econômico guiado pela esfera federal. As 284 páginas desse Plano, divididas em dez capítulos, agrupavam-se em 4 partes distintas: uma breve introdução, seguida pela política de expansão e aprimoramento da infraestrutura, política de desenvolvimento industrial e incentivos a formação e educação da mão de obra especializada.

Cabe, então, realizar uma análise do que seria o contexto que condicionaria as mudanças de foco das ações da SUDENE. Para isso, faz-se necessário entender a politica econômica que a Ditadura Militar (1964 - 1985) viria a executar nos moldes estabelecidos desde seu Plano de Ação Econômica do Governo (PAEG), de 1966.

Partindo do contexto da política econômica nacional, torna-se possível então realizar a análise dos planos diretores para se estudar a visão do autor o papel e a influência da SUDENE, em perspectiva crítica.

\section{O Contexto da Política Econômica Nacional: O Plano de Ação Econômica do Governo (PAEG)}

Após um período de crise política que levou ao golpe de 01 de Abril de 1964, o foco das políticas econômicas se alterou, não mais era o desenvolvimento econômico o objetivo final das ações governamentais da União, foram implementadas, então, políticas voltadas ao "ajuste fiscal" e a concentração do poder de atuação estatal na esfera federal. O principal indicador do viés da política econômica imposta pela ditadura militar foi o Programa de Ação Econômica do Governo (PAEG). Conforme Souza (in PIRES, 2010, p. 191): “O PAEG não 
foi efetivamente um plano de desenvolvimento. Mesmos seus defensores o apontam como um plano de 'ajuste"'.

É nos termos dessa política econômica que a SUDENE, em 1966, a época com menos de uma década de existência, publicaria seus três planos diretores iniciais. Eles descreveriam e estabeleceriam ações a serem realizadas pela superintendência entre os anos de 1961 a 1968. Há uma diferença significativa observada entre o primeiro e os outros planos. O plano de 1961, anterior à crise política e ao Golpe de 1964, teria ainda foco no desenvolvimento da infraestrutura nordestina, segmento que representaria $75 \%$ dos recursos alocados e que passaria a representar em média 45\% no Planos de 1963 e 1966. Haveria, ainda, um quarto plano, apresentado em 1968, expandindo o período de planejamento até 1973.

Teríamos então um processo de restruturação dos modos de produção no Nordeste, onde ainda se podia encontrar mercados com traços pré-capitalistas, com distribuição de mercadoria através do escambo e sem infraestruturas capazes de deslocar produção numa escala coerente com os mandos de uma economia capitalista moderna. Tal restruturação, implantada em parte pelos Planos da SUDENE, abriria os espaços do Agreste e do Sertão nordestinos a uma economia globalizada. Isso não era, de forma alguma um fenômeno único ao Nordeste, foi uma imposição exógena ao sistema produtivo nordestino e seria processada pelas especificidades desse sistema e por sua disponibilidade de recursos, mas teria em se um caráter inerente as mudanças da economia global que visava integrar os mercados regionais a uma dinâmica capitalista globalizada. Sobre o fenômeno das integralizações econômicas se debruçou Ruy Mauro Marini, que apontou:

"É neste esquema que os atuais projetos de integração regional e a ditadura aberta da classe representada pelos regimes tecnocrático e militar desempenham um papel predominante. Na América Latina, a integração econômica torna-se uma forma de pôr fim à integração imperialista do sistema produtivo, numa situação econômica de crescente potencialidade de oferta e de restrição sistemática das possibilidades de consumo." (MARINI, 1972, p.22 $2^{52}$ )

Teriam, então, os governos militares transmitido e consolidado as tendências do capital mundial para o Nordeste, sendo esses, segundo Manoel Correia e em similar argumentativa a

52 No original: "C'est dans ce schéma que les projets actuels d'intégration régionale et la dictature de classe ouverte représentée par les régimes technocratiques et militaires jouent un rôle prédominant. En Amérique latine, l'intégration économique devient un moyen de mettre fin à l'intégration impérialiste du système productif, dans une situation économique caractérisée par un potentiel d'offre croissant et une restriction systématique des possibilités de consommation." 
Ruy Mauro, agentes que viriam a beneficiar o grande latifúndio capitalista de maneira que: “Com os governos militares os grandes proprietários conseguiram enfraquecer seriamente o movimento trabalhador e passaram a firmar diretrizes capitalistas para o campo." (ANDRADE, 1994b, p.41)

Outro aspecto do avanço do modelo capitalista sobre os mercados regionais se dariam então com o esmagamento das classes camponesas, em benefício da forma do latifúndio capitalista. Para que isso fosse possível, seria necessária a modernização do maquinário no campo, e a disseminação de uma mentalidade agrícola tecnocrática, a qual seria realizada com a deterioração dos padrões de vida dos trabalhadores rurais, os quais se viriam forçados a buscar renda nos centros urbanos, muitas vezes através do trabalho informal ou em outras regiões rurais adaptando suas vidas aos regimes sazonais das diversas culturas do país.

Os movimentos do capital internacional exerceriam sua influência sobre as forças de mudança da economia nordestina, mas não como um fator exógeno que se chocaria com as estruturas produtivas encontradas no Nordeste. Isso só tenderia a acontecer em casos de atividades de menor significância para o mercado internacional, como por exemplo o caso da cultura de coqueirais que se encontra deteriorada e limitada as áreas inviáveis a cultura canavieira na zona da mata e no litoral oriental. O capital internacional seria, então, um fator exógeno que guiaria a mão dos governos militares, para assim limitar as ações de mudança econômica somente àqueles aspectos que lhe fossem pertinentes, de forma a garantir a produção em grande escala de produtos primários, com um mercado aberto, e sem um mercado interno capaz de concorrer com suas demandas. A direção dessas mudanças seriam assim definidas por Ruy Mauro Marini como:

“O projeto do sub-imperialismo partiu das demandas do capital e forneceu novas oportunidades de mercado e facilidades para explorar o trabalho mais imediatamente. para isso, teve que atuar em duas frentes: complementar o mercado interno pelo consumo público e abrir as portas do mercado externo para ele. No primeiro caso, e uma vez que já não se pensava em estimular o consumo popular, o propósito do suplemento menos para obras de benefício social do que para criar mais facilidades para sua reprodução, ou de absorção de uma parte dele que não poderia ser usada para consumo popular. Algumas dessas obras, como os investimentos para a expansão do sistema de geração de energia elétrica, serviram para ambos os propósitos. Aumentaram a disponibilidade de energia ao mesmo 
tempo que absorveram bens produzidos por diferentes setores industriais." (MARINI, 1972, p.102 $2^{53}$ )

A SUDENE passaria, através de suas politicas de financiamento e estímulo ao crescimento da agroindústria, a ser um "aviso prévio" da tendência geral de consolidação da burguesia agroindustrial capitalista, como afirma Francisco de Oliveira ${ }^{54}$.

Dessa forma, o PAEG também faria parte de uma tendência maior da economia mundial, estaria esse imbricado em um processo de consolidação de uma nova forma de divisão internacional do trabalho, que vinha se disseminando do centro hegemônico de maneira a ajustar as estruturas produtivas locais e delimitar as potencialidades econômicas específicas das regiões do país (MARINI, 1972,p.23). Sendo assim, o planejamento regional teria caráter estruturante integrador das especificidades Nordestinas a planejamento nacional, formando assim uma hierarquia do centro hegemônico mundial, ao centro produtivo nacional, localizado nas regiões do Sul, Sudeste e Centro-oeste do país, para em última instância, chegar ao Norte e Nordeste do Brasil.

O segundo plano já refletiria a direção da política econômica tomada pelo PAEG, coadunando a retração fiscal e o arrocho nos investimentos. As novas diretrizes passaram a concentrar-se nas economias externas voltadas ao setor privado, nos estudos sobre recursos naturais da região, e na promoção da iniciativa privada voltada ao mercado externo, orientação essa que se perpetuará em maior ou menor grau no terceiro e quarto plano diretor.

Outra mudança que passou a delimitar as competências das instituições promotoras do desenvolvimento se deu através da Lei $\mathrm{n}^{\circ}$. 4.504, de 30 de novembro de 1964, estabelecendo o Estatuto da Terra, o qual definiria a abrangência da reforma agrária, segundo o inciso primeiro do artigo primeiro:

“Considera-se Reforma Agrária o conjunto de medidas que visem a promover melhor distribuição da terra, mediante modificações no regime de sua posse e uso, a fim de atender aos princípios de justiça social e ao aumento de produtividade."

53 No original: "Le projet sous-impérialiste partit des revendications du capital et leur fournit de nouvelles occasions de marché et des facilités pour exploiter davantage et immédiatement le travail. pour ce faire, il devait agir sur un double front : compléter le marché interne par la consommation publique et lui ouvrir les portes du marché extérieur. Dans le premier cas, et une fois que l'on ne pensait plus à stimuler la consommation populaire, le complément avait moins pour objet des œuvres à avantage social que pour fin soit de créer de plus grandes facilités à sa reproduction, soit d'absorber une partie de ce qu'il ne pouvait destiner à la consommation populaire. Certaines de ces œuvres, comme les investissements destinés à l'agrandissement du système de production d'énergie électrique, satisfaisaient à ces deux fins. Elles augmentaient les disponibilités énergétiques en même temps qu'elles absorbaient des biens produits par différents secteurs industriels."

54 Em sua obra "Noiva da Revolução, Elegia para uma re(li)gião" de 2008, Página 264. 
Dessa forma, um dos principais pontos até então promovidos, o aumento da oferta de terras, passaria a ter limites definidos pelo Estatuto. Somente as terras que não contemplassem uma série de critérios estariam sujeitas à reforma agrária. Seriam eles, segundo o artigo $2^{\circ}$., inciso $1^{\circ}$. da referida Lei:

"A propriedade da terra desempenha integralmente a sua função social quando, simultaneamente:

a) favorece o bem-estar dos proprietários e dos trabalhadores que nela labutam, assim como de suas famílias;

b) mantém níveis satisfatórios de produtividade;

c) assegura a conservação dos recursos naturais;

d) observa as disposições legais que regulam as justas relações de trabalho entre os que a possuem e a cultivem."

O Estatuto definia "latifúndio" como o imóvel rural cuja área excedesse a seiscentas vezes o módulo médio da propriedade rural ou a seiscentas vezes a área média do imóvel rural de uma determinada região. Tal definição permitiria a proliferação dos estabelecimentos de maior porte ao categorizar o latifúndio como propriedade distinta do pequeno e médio imóvel rural. Dessa forma as políticas de reforma agrária teriam de considerar a produtividade média dos latifúndios perante a dos demais latifúndios e não mais a produtividade média dos estabelecimentos rurais. A tabela 19 traz a evolução do número de estabelecimentos rurais por agrupamento de área de ocupação em hectares.

Tabela 19.Número de Estabelecimentos Rurais por área de ocupada de 1955 - 1980

\begin{tabular}{lrrrr}
\hline Numero de Estabelecimentos & 1955 & 1960 & 1975 & 1980 \\
\hline Menos de 10 ha & 135.733 & 206.058 & 1.641 .931 & 1.654 .841 \\
De 10 a 99 ha & 18.288 & 95.095 & 567.033 & 637.263 \\
De 100 a 499 ha & 4.336 & 38.889 & 2.078 .959 & 2.174 .421 \\
De 500 a 1000 ha & 480 & 5.075 & 131.045 & 141.134 \\
Acima de 1000 ha & 522 & 3.444 & 9.120 & 10.235 \\
\hline Total & 159.359 & 348.561 & 4.428 .088 & 4.617 .894 \\
\hline
\end{tabular}

Fonte: ANDRADE 1961, 1955 e 1960; demais anos, IBGE.

Considerando as informações da tabela houve, então, um aumento generalizado do número de estabelecimentos rurais no Nordeste. É possível ponderar a variação percentual dos agrupamentos por área ocupada dos estabelecimentos. Com isso, percebe-se um avanço significativo nos grupos de maior porte, com estabelecimentos de 500 a menos de 1000 hectares aumentando $1057,29 \%$ de 1955 a 1960, valor superior ao crescimento dos estabelecimentos totais que no mesmo período cresceria $218,73 \%$. Durante os quinze anos de 
1960 a 1975, seriam os estabelecimentos com 100 a 500 hectares que se proliferariam, aumentando de 38.889 para 2.078.959, uma variação total de 5345,88\%.

O Estatuto da Terra através da definição da reforma agraria e de seus limites gerou, incoerentemente, uma tendência de maior proliferação das grandes propriedades rurais. Nas décadas de 1960 e 1970 seria o grupo de pequenos proprietários o que mais lentamente se propagaria pela região mostrando uma expansão de $151 \%$ de 1955 a 1960 e de $796,83 \%$ de 1960 a 1975.

\section{Manoel Correia de Andrade e a SUDENE}

A primeira interação de Manoel Correia com a SUDENE foi a avaliação da eficacia e limitação das ações da SUDENE de 1959 a $1963^{55}$, na qual Manoel Correia ao expor "as tentativas de solução do problema agrário" elogia as iniciativas de criação de uma infraestrutura de base, assim como os investimentos nas esferas da saúde e educação. Entretanto, já na primeira edição de sua mais famosa obra, Manoel Correia apontava para o "problema humano", como um possível impedimento para a efetiva superação do subdesenvolvimento crônico.

Nessa medida, em 1963, já haviam se estabelecido as bases da hipótese elaborada por Manoel Correia, em diversas obras como "Modernização e Pobreza" de 1994 , "O Nordeste e a Questão Regional" de 1993 e na 8' edição de "A Terra e o Homem no Nordeste" de 2005, na qual o crescimento econômico seria o processo no qual "O Nordeste sofre do que poderíamos chamar de um crescimento sem mudanças reais, apenas formais.” (ANDRADE, 2005).

Já a relação institucional de Manoel Correia começaria em 1969, com o início da publicação de um conjunto de estudos regionais pela SUDENE. neles, é publicado "Agricultura e regionalização no nordeste: Pecuária e extrativismo vegetal”. Em seguida foram publicados em 1975 a primeira edição de "O Processo de Ocupação do Espaço Regional no Nordeste" e "Polarizações para João Pessoa". A produção de pesquisa para a SUDENE, assim, continua com a segunda edição de "O Processo de Ocupação do Espaço Regional no Nordeste" em 1979.

As obras públicas de Manoel Correia pela SUDENE acabam na década de 1980, com "Produção do espaço e A 85/59. regionalização em Pernambuco" em 1981, "Áreas de domínio da pecuária extensiva e semi-intensiva na Bahia e Norte de Minas" e "A propriedade

55 Essa pode ser encontrada no capítulo VI, páginas: 227 - 243, de "A Terra e o Homem no Nordeste" $1^{\text {a }}$ Edição de 1963. 
da terra e as transformações recentes da agricultura pernambucana." ambas em 1982, “Sertão Sul" em 1984.Por fim, em 1988, foi publicado o estudo "Área do sistema canavieiro".

\section{A Questão Agrária: As Visões de Caio Prado e Manoel Correia Sobre a Problemática do Fator "Humano" no Nordeste}

Durante praticamente toda a sua vida acadêmica, Manoel Correia teve laços próximos a Caio Prado Júnior. Foram companheiros no Partido Comunista Brasileiro (PCB), onde defendiam a necessidade de uma reforma agrária que proporcionasse um padrão de vida mais elevado e mais "humano" para as populações trabalhadoras rurais. É esse o principal ponto de convergência ideológica dos dois historiadores, fato esse que teria levado Caio Prado a "encomendar" um livro sobre a questão agrária a Manoel Correia, que em resposta escreveria a primeira edição de "A Terra e o Homem no Nordeste: Contribuições ao Estudo da Questão Agrária no Nordeste." que seria publicada pela editora Brasiliense, da qual Caio Prado foi cofundador, em 1943.

Manoel Correia viria a incorporar na sua análise da problemática nordestina a ênfase que Caio Prado dava ao fator humano nos entraves econômicos a superação do subdesenvolvimento regional. Ele adaptaria a noção de que:

"Os problemas agrários, como quaisquer outros problemas sociais e econômicos, são antes de tudo "humanos". E são por isso os homens e a posição que respectivamente ocupam nas atividades agropecuárias, que devem ser consideradas em primeiro e principal lugar, e como elemento central que configura todas as questões a serem analisadas." (PRADO JÚNIOR, 1979, p.20)

Essa concepção do problema econômico esta centrado no homem e na sua posição no processo de produção e distribuição da riqueza seria compartilhada por Manoel Correia que dá aponta para isso como um dos principais fatores de contenção da eficacia das ações da SUDENE no Nordeste, dizendo que: "Achamos mesmo que ela (a SUDENE) se descuidou um pouco do problema humano(...)” (ANDRADE, 1998, p. 242). Dessa forma, ambos os autores deixam de dar ênfase primária ao meio físico como fator de perpetuação da pobreza no Nordeste.

Ao descrever o processo de transição que se encontrava a economia brasileira na década de 1960, Caio Prado, trata das mudanças implementadas pelo PAEG como uma força dinamizadora que viria a modificar o sistema produtivo brasileiro sem que com isso fosse 
possível alterar os elementos fundamentais do controle da distribuição da renda, apontando assim:

"Essa nova e tão mais complexa estrutura social brasileira, apesar das consideráveis diferenças que a separam do passado, não logrou ainda superar inteiramente esse passado, e ainda assenta, em última instância, nos velhos quadros econômicos da colônia, com seu elemento fundamental que essencialmente persiste, e que vem a ser a obsoleta forma de utilização e organização agrária que daí resulta.” (PRADO JÚNIOR,1979,p 49)

Dessa forma, seria similar a importância atribuída por Caio Prado a forma com as quais a estruturas econômicas brasileiras alocam os fatores produtivos e quais castas sociais que dominam o processo de transformação de tais estruturas com a argumentação de Manoel Correia ao tratar dos principais fatores de entrave ao desenvolvimento do Nordeste. Teríamos assim que, para ambos os autores, os elementos de perpetuação da pobreza encontrariam suas raízes na arcaica organização da propriedade das terras que proporciona as bases de poder políticos que concentram a renda e disseminam a miséria na população trabalhadora rural. Manoel Correia nesse sentido aponta que:

“(...) a pobreza que domina a região é o resultado de uma série de fatores que confluem para dificultar e entravar um processo natural de desenvolvimento, e que estes fatores são mais de ordem social do que física. Ela é comandada por um sistema que beneficia os grupos dominantes que se opõem a qualquer transformação estrutural que possa tocar nos seus interesses e que até se beneficia do flagelo das secas, captando verbas que dinamizam os seus negócios e consolidam o seu poder político." (ANDRADE, 1993,p. 48-49)

A questão agrária então seria vista tanto por Caio Prado como por Manoel Correia por seu papel estruturante nas formas de organização social. Quaisquer ações governamentais desenvolvidas, então, com intuito de dinamizar a economia do agronegócio para superar o subdesenvolvimento teria de levar em consideração como o poder político seria utilizado para condicionar e limitar a distribuição das terras e, por consequência, da renda, evitando assim concatenação das ações políticas ao interesses dos ricos latifundiários. 


\section{A SUDENE como Agente de Expansão do Capitalismo:}

Durante as décadas de 1960, 1970 e 1980, o Nordeste aumentou sua produção em função da ação governamental em prol da modernização das estruturas do campo e do aprimoramento dos parques industriais nas grandes capitais do litoral oriental, principalmente em Recife, João Pessoa e Salvador. Com isso, foi possível ao Nordeste mostrar desempenhos de crescimento do PIB maiores que a média nacional, sendo o crescimento médio do PIB do Brasil de 1961 a 1990 de 5,52\% ao ano, enquanto a média do Nordeste atingiria o patamar de $5,71 \%$ ao ano.

Paralelamente ao crescimento da produção, ocorreu uma intensificação da desigualdade, com proliferação dos grandes estabelecimentos rurais e aumento da população alocada em regiões urbanas. A tabela 20 traz o índice de desigualdade $\mathrm{L}$ de Theil para os anos de 1970, 1980 e 1991. Esse índice é calculado pela razão entre as médias aritméticas e geométricas da renda familiar per capita média aponta o grau de distribuição da renda, com L $=0$ para renda igualitariamente distribuída e $\mathrm{L} \rightarrow \infty$ para renda plenamente concentrada.

Tabela 20. Índice L de Theil para a região do Nordeste, anos 1970, 1980 e 1991.

\begin{tabular}{cc}
\hline Região & Nordeste \\
\hline 1970 & 0,57 \\
1980 & 0,65 \\
1991 & 0,78
\end{tabular}

Fonte:Instituto de Pesquisa Econômica Aplicada (IPEA) em :http://www.ipeadata.gov.br/Default.aspx acesso dia $15 / 03 / 2018$ às $15: 56$

Os esforços de modernização e industrialização da SUDENE, então, não teriam os efeitos esperados, sendo absorvidos por uma antiga estrutura de produção instigando uma desigualdade que converteu de uma economia dominada pelo senhor de engenho para uma economia dominada pelo usineiro capitalista. A incapacidade dos Planos está ligada a sua miopia quanto à incapacidade dos trabalhadores rurais de se beneficiarem da oferta ampliada de terras. Terra essas com preços altos e incompatíveis com a renda de grande parte da população do Nordeste. Quanto a esse problema Caio Prado Júnior apontaria, em escala nacional, que:

"Esse alto preço (...) constitui embaraço intransponível a qualquer programa de reforma agrária. Mais que isso, ele representa nos dias que correm o maior óbice oposto ao desenvolvimento e progresso, em escala apreciável, da nossa agropecuária." (PRADO JÚNIOR,1979,p.132-133) 
Manoel Correia de Andrade assumiria uma postura similar a Caio Prado Júnior, apontando para a concentração uso da terra em grandes latifúndios como um fator de perpetuação de um modelo econômico subdesenvolvido com "sub-exploração da terra" e "sub-utillização da mão de obra", como afirma Manoel Correia ${ }^{56}$. Seria necessário, então, um processo de desconcentração das terras que contemplassem não só o caráter econômico, mas também, as estruturas de poder vigentes no Nordeste. Ampliando o escopo do problema da reforma agrária para o que Manoel colocou como:

"(...) a reforma agrária é necessária e que ela não se limita a uma reforma da estrutura fundiária, do sistema de posse e uso da terra; ela só ocorrerá se houver séria política de redistribuição de terras nas áreas já ocupadas e uma sistemática política de colonização com pequenas propriedades nas áreas de povoamento." (ANDRADE, 1981, p. 35)

Sendo assim, o aumento na oferta de terras e a expansão da infraestrutura realizada pela SUDENE nas décadas de 1960 e 1970 levariam a uma intensificação do processo de acumulação do capital, sem que isso gestasse oposição à sistemática de dominação do espaço nordestino.

A consequência de tal crescimento econômico, guinado pelo estado sem enfrentar os problemas estruturais da sociedade nordestina, seria a destruição de quaisquer grupos econômicos que fizessem frente ao domínio das atividades primário-exportadoras. Daí tem-se a perda de relevância do setor algodoeiro e uma nova falência da pecuária em estabelecer-se como atividade dinâmica nas décadas de 1970 e 1980. Quanto a esse fenômeno, Manoel Correia apontou que:

"A Programação (da SUDENE) feita, porém, atende, a curto prazo, aos grupos dominantes, por lhes trazer maior acumulação de capital e um maior poder político, mas o empobrecimento geral da população, cria desequilíbrios que têm repercussões políticas, sociais e econômicas que desestabilizam as estruturas de controle e podem levar a região e o país a uma instabilidade que seria evitada se se fizessem as reformas mais realistas, modificando o equilíbrio de forças existentes e fornecendo ao povo uma maior participação na riqueza que ele produz.” (ANDRADE, 1981, p.79)

56 Afirmando isso na Obra "A Reforma Agrária Ainda é Necessária?" de 1981, capítulo 2. Página 54. 
Assim sendo, as ações da SUDENE buscariam reestruturar de elementos conjunturais, enfatizando as forças de controle locais através de implementação de um conjunto de maquinários e técnicas de produção modernizado, os quais aumentariam a produtividade das atividades dominantes imbuindo-as de capacidade competitiva, o que por sua vez tornaria os mercados do Nordeste mais competitivos e mais hostis a proliferação de alternativas as atividades já consolidadas. Esse processo não seria algo exclusivo ao Nordeste, Teotônio dos Santos viria a categorizar essa tendência de ação dos órgãos governamentais como sendo um fenômeno recorrente na economia mundial. Ele assim apontou:

“(...) a reestruturação da economia mundial se baseará na incorporação das novas tecnologias cujas escalas de produção são cada vez mais da ordem planetária. Isto leva à necessidade de aumentar os espaços econômicos em mercados planetários ou, pelo menos, regionais para tornar viável a operação das empresas de alta tecnologia e para introduzir as importantes inovações econômicas já em fase de liquidação impiedosa dos mercados locais e sub-regionais dentro dos países e uma tentativa de integração de mercados internacionais dentro dos espaços regionais delimitados por acordos entre estados." (SANTOS, 1994,p.42)

Considerando o efeito devastador que o processo de acumulação e crescimento desenfreado nos setores dominantes da economia Nordestina teria sobre as especificidades do modelo produtivo do Nordeste, Francisco de Oliveira, chegaria a uma visão similar à de Manoel Correia, tratando a SUDENE após o golpe de 1964 como um agente transmissor da nova configuração do modelo produtivo desenvolvido no Centro-sul, impactando a economia nordestina de maneira que:

"Os poucos e contados grupos econômicos regionais que sobreviveram fizeram-no porque conseguiram se elevar ao mesmo nível dos grandes grupos monopolistas da economia nacional e, em certos termos, já o eram ou estavam caminhando para sê-lo na época da criação da SUDENE; os favores fiscais administrados por esta the serviram igualmente como mecanismo de concentração e centralização do capital. $\mathrm{O}$ resto da burguesia industrial nordestina foi irremediavelmente jogado ao lixo da História. Dies irae, dies irae." (OLIVEIRA, 2008, p.272, 273 e 274) 
A ação governamental pelo planejamento, financiamento e monitoramento desenvolvida sob o governo militar, utilizaria o mantra de superação do desenvolvimento econômico guiado pela SUDENE para mobilizar as forças dominantes e as forças dominadas do Nordeste em prol de um sistema produtivo com concentração de renda e voltado para o abastecimento de mercados externos, criando um estado de subdesenvolvimento dependente de casta social voltada a remessa de excedentes para o mercado internacional e criando com isso um forma de capitalismo ainda mais dependente, mais concentrado, que marginaliza e excluí grande parte de sua população trabalhadora (SANTOS,1994,p.77).

\section{O Agente Dinamizador de Celso Furtado e a Crítica de Manoel Correia de Andrade}

Celso Furtado fez parte do contingente inicial da Comissão Econômica para a América Latina (CEPAL) criada com objetivo de gerar conhecimento empírico e rodar constantes simulações buscando identificar e prever possíveis flutuações nas poupanças, nas taxas de juros e das suas relações com a criação de capital produtivo (BARBOSA,2004). Na CEPAL Furtado participou do debate que viria a formar a ideologia estruturalista latino-americana. Influenciado por uma tradição Keynesiana, herdade em grande medida de seus dias como membro da CEPAL, Furtado elaborou uma visão dualista da economia mundial, na qual se poderia encontrar sistemas econômicos Desenvolvidos e sistemas econômicos Subdesenvolvidos.

É dessa visão dualista que Furtado baseia duas obras de fundamental importância para se entender a formação e a ação da SUDENE, sendo essas “A Operação Nordeste” de 1959 na qual, o autor, diagnostica as razões para a desigualdade do crescimento econômico nas regiões do Brasil, e "Desenvolvimento e Subdesenvolvimento" onde Furtado expõe sua teoria do subdesenvolvimento, partindo assim com a noção disseminada a época de que o subdesenvolvimento seria apenas uma "etapa" no caminho para o desenvolvimento.

Ao assumir a SUDENE Furtado foi recebido com resistência pela direita política nacional, que percebiam o economista como um propositor de uma heterodoxia econômica centrada na ação e intervenção governamental. Wilson do Nascimento Barbosa descreve em seu artigo "Relembrando a formação da CEPAL" de 2004, a reação inicial da direita como sendo:

“Os exageros próprios da direita politica não podiam entender assim. Como exemplo, quando Celso Furtado foi indicado para organizar a SUDENE foi tratado pela mídia quase como um interventor estrangeiro. Participar da Cepal ou expressar vistas keynesianas 
caracterizava para a direita falta grave e até um desafio ao governo dos Estados Unidos.” (BARBOSA,2004, p.186)

O trecho aponta assim para um segmento da sociedade que resistiria as mudanças implementadas pela SUDENE de Furtado e de fato esse seria um fator de contenção da eficácia das ações elaboradas. A esfera política, tanto nacional como regional estaria sempre presente nas delimitações impostas as mudanças estruturais promovidas dentro da política de desenvolvimento objetivada pela superintendência e pelo próprio furtado. Ao fator político é dado tão grande importância na determinação dos limitantes das políticas de desenvolvimento que na obra "Seca e Poder: Entrevista com Celso Furtado", onde o economista foi entrevistado por Maria da Conceição Tavares, Manoel Correia de Andrade e Raimundo Rodrigues Pereira, é atribuída "a responsabilidade maior é da classe política nordestina”.

Ao tomar o processo de industrialização que acontecerá na região Sudeste do Brasil a partir da década de 1930, Furtado buscou estabelecer como a conjuntura da economia internacional e regional, corroboraram para criar um ambiente propício ao surgimento de um fator de mudança estrutural, que levaria, através da industrialização, a uma estrutura diferenciada mais economicamente desenvolvida. Para São Paulo e os demais estados que viram a formar o polígono industrial Brasileiro pós década de 1930,a saber, a área de: Belo Horizonte - Uberlandia - Londrina/Maringá - Porto Alegre - Florianópolis - São José dos Campos Belos - Belo Horizonte (DINIZ,1993), Furtado aponta três fatos primordiais a serem considerados (I) A mudança do foco da economia para o mercado interno, (II) a existência de um excedente agrícola criado pela economia do setor cafeeiro que iria ser alocado para compra de produtos industriais nacionais em um processo de substituição de importações e (III) uma política cambial voltada ao estímulo das exportações e redução do volume de importações, efetivamente reduzindo temporariamente a concorrência entre a indústria brasileira nascente e o mercado de bens de capital internacional.

Dessa forma, a industrialização brasileira da primeira metade do século XX se daria utilizando-se da formação de capital fixo nacional, com base em um mercado produtor de bens de capital nacional, que para abastecer o consumo interno necessitária de uma reestruturação da oferta desses bens. A industrialização dada a partir da década de 1930 seria um fenômeno que partiria de mudanças na oferta (FURTADO, 2009). Sobre a importância de tais mudanças, Furtado apontou:

"O crescimento da procura de bens de capital, reflexo da expansão da produção para o mercado interno, e a forte elevação dos preços de importação desses bens, acarretada pela depreciação cambial, criaram 
condições propícias à instalação no país de uma indústria de bens de capital. Esse tipo de Indústria encontra, por uma série de razões óbvias, sérias dificuldades para instalar-se em uma economia dependente." (FURTADO, 2009, p.279)

Temos, então, que as mudanças que fariam a transição de uma economia subdesenvolvida para uma economia desenvolvida necessitaria de um agente dinamizador. Para Furtado, esse agente seria a indústria que, ao amadurecer, absorveria necessários do velho sistema produtivo agrícola e criaria um mecanismo mais eficiente de acumulação de capitais, gerando uma taxa crescimento econômico no padrão das economias desenvolvidas.

Antes de considerar a crítica à noção estruturalista reformista realizada por Manoel Correia, cabe, agora delimitar o que seria, na visão Furtadiana, o Desenvolvimento Econômico. O conceito de Desenvolvimento Econômico seria foi incorporado ao mainstream econômico por Joseph Alois Schumpeter com a publicação de sua obra "A Teoria do Desenvolvimento Econômico: Uma Investigação Sobre Lucros, Capital, Crédito, Juros e o Ciclo Econômico ${ }^{57 "}$ de 1911, onde Schumpeter caracteriza o fenômeno do desenvolvimento econômico como uma mudança no padrão de crescimento econômico de uma nação em função de uma alteração nas formas da sociedade de alocar seus fatores produtivos, aumentando a produtividade social, através de um processo inovativo iniciado pela figura do empreendedor, financiado pelo sistema bancário e disseminado pelas firmas imitadoras.

Furtado utiliza um conceito similar ao Schumpeteriano ao caracterizar o desenvolvimento econômico como um aumento significativo na produtividade dos sistemas produtivos. Entretanto, os avanços da economia que levariam uma economia ao desenvolvimento, para Furtado, seriam focados nas mudanças das estruturas produtivas de uma sociedade, seja ela gerada por uma inovação, ou pela simples absorção de capital internacional. Assim sendo, Furtado define o desenvolvimento econômico como:

“(...) basicamente, aumento do fluxo de renda, isto é, incremento da quantidade de bens e serviços, por unidade de tempo, à disposição de determinada coletividade. Trata-se, portanto, de conceito relacionado com elementos quantificáveis.” (FURTADO, 1961, p.115)

O Desenvolvimento, então passaria de uma transformação pontual irradiando para os outros setores da economia, de maneira a promover, inicialmente baseado em uma economia pré capitalista, uma acumulação de capital interna voltada a um mercado interno. O processo

57 No original: "Theorie der wirtschaftlichen Entwicklung." 
de transformação começa com uma primeira (I) fase acumulação de excedente de uma atividade primário exportadora que se encontre em um período de crescimento, no caso brasileiro essa foi a cafeicultura de final do século XIX e das primeiras duas décadas do século XX (FURTADO,2009).Essa fase seria seguida por uma segunda, onde (II) o foco da procura de bens e serviços se voltaria para o mercado interno, iniciando um processo de industrialização autônomo e voltado para o abastecimento interno, nessa fase haveria a formação de um capital industrial que, devido a sua escassez relativa a disponibilidade de trabalho e terra, tenderia a concentrar a renda nas mãos de uma nova burguesia industrial. Por fim tem-se uma terceira etapa (III) onde o capital industrial torna-se cada vez mais relativamente abundante e a oferta de mão de obra, com a criação dos sindicatos trabalhistas, cada vez menos elástica, levando a desconcentração da renda. Tal processo ocorreria de maneira que:

"Em uma economia que haja alcançado certo grau de desenvolvimento, a produção apresenta uma estrutura tal que a acumulação se torna um processo quase automático. Destarte, para que o aparelho produtivo funcione normalmente é indispensável que também a procura apresente certa composição. Ora, a composição da procura está determinada pela distribuição da renda, isto é, pela forma como os distintos grupos se apropriam do produto. Cabe, portanto, concluir que a estrutura da produção, a parcela da produção que se destina à acumulação e a distribuição da renda tem todas as mesmas causas fundamentais. Estas assentam no sistema institucional que se articula em torno do processo de apropriação do excedente. (FURTADO, 1961, p.122)

Furtado contestaria a concepção difundida à época de que o Subdesenvolvimento, ou menor ritmo de crescimento econômico, seria um fenômeno do processo de evolução das economias. Elaboraria, então, uma teoria para a qual a consolidação das nações desenvolvidas ocorreria em paralelo à formação dos elementos do subdesenvolvimento. Dessa forma, a economia mundial teria se configurado em duas formas, a saber: uma primeira, com um maior ritmo de crescimento, com mercado interno representativo na alocação de recursos e produtor de bens de capital; uma segunda, subordinada à primeira, com sua produção dependente do mercado externo e dedicada à produção de bens de consumo e matérias-primas. Assim, Celso Furtado conceitua o subdesenvolvimento como: 
“O subdesenvolvimento é, portanto, um processo histórico autônomo, e não uma etapa pela qual tenham, necessariamente, passado as economias que já alcançaram grau superior de desenvolvimento. Para captar a essência do problema das atuais economias subdesenvolvidas necessário se torna levar em conta essa peculiaridade. Consideremos o caso típico de uma economia que recebe uma cunha capitalista, sob a forma de atividades produtivas destinadas à exportação.(FURTADO, 1961, p.180-181)

A divisão entre desenvolvimento e subdesenvolvimento não ocorre de forma uniforme. De fato, tanto em nível mundial, como regional, surgindo esporadicamente, seguindo os mandos e desmandos do capital internacional. Furtado aponta para a desigualdade no crescimento econômico nacional, tratando-a como um elemento institucionalizado na estrutura do processo produtivo brasileiro:

“A desigualdade econômica, quando alcança certo ponto, se institucionaliza. Tal fato, que observamos nas sociedades humanas tendência das desigualdades a se institucionalizarem e formar classes -, também pode ocorrer entre as regiões do mesmo país. Quando a desigualdade entre níveis de vida de grupos populacionais atinge a certos limites, tende a institucionalizar-se. E quando um fenômeno econômico dessa ordem obtêm sanção institucional, sua reversão espontânea é praticamente impossível.” (FURTADO, 1959, p. 14-15)

O maior ponto de divergência entre Furtado e economistas como Caio Prado e Manoel Correia de Andrade seria a existência da autonomia do processo econômico do desenvolvimento tende, dado um ambiente econômico favorável, a se desenvolver autonomamente dentro de uma dinâmica econômica. Manoel Correia e Caio Prado apontam para o fator humano na transmissão das mudanças econômicas. Dessa forma, quaisquer iniciativas governamentais para mudanças estruturais devem levar em consideração as formas como os seres humanos, numa sociedade, processam as ações governamentais.

A desigualdade de ritmo de crescimento entre as regiões Sul, Sudeste, Centro-oeste para o Nordeste brasileiro seria devida a um precedente histórico, no qual, não haveria uma atividade já estabelecida, capaz de criar o excedente para iniciar o processo de industrialização regional. No Sudeste, houve uma atividade cafeeira capaz de alocar renda para o desenvolvimento de um mercado interno no começo do século XX. No Nordeste, Furtado aponta que: 
“(...) foi este processo de formação histórica da economia nordestina: quando as exportações do açúcar perderam o impulso de crescimento, esgotou-se toda a força dinâmica do sistema, que se revelou incapaz de propiciar a transição automática para a industrialização." (FURTADO, 1959, p.24)

Coma a mudança do foco para o abastecimento de um mercado interno, iniciou-se um conjunto de mudanças aparentemente autônomas que levariam ao surgimento do polígono industrial. Somente o estado de São Paulo chegou a representar $44 \%$ e $58 \%$ da produção industrial brasileira nas décadas de 1960 e 1970 respectivamente. Furtado interpretaria tais transformações como um sinal da tendência nacional de superação da dependência para com o setor externo:

“A transformação estrutural mais importante que possivelmente ocorrerá no terceiro quartel do século XX será a redução progressiva da importância relativa do setor externo no processo de capitalização. Em outras palavras, as indústrias de bens de capital.” (FURTADO, 2009, p.327)

A solução proposta por Furtado, então, se daria nesse contexto de mudanças estruturais na região sudeste, com a ação governamental como fator integrador da economia nacional e racionalizador da utilização dos recursos. Demandar-se-ia politicas econômicas voltadas ao fim da disparidade dos ritmos de crescimento econômico entre as regiões brasileiras, para com isso formar um mercado interno:

“A solução desse problema constituirá, muito provavelmente, uma das preocupações centrais da política econômica no correr dos próximos anos. Essa solução exigirá uma nova forma de integração da economia nacional, distinta da simples articulação que se processou na primeira metade do século. A articulação significou, simplesmente, desviar para o mercado da região cafeeiro-industrial produtos que antes se colocavam no exterior. Um processo de integração teria de orientar-se no sentido do aproveitamento mais racional de recursos e fatores no conjunto da economia Brasileira.” (FURTADO, 2009,p. 333)

As maiores críticas realizadas por Manoel Correia às políticas econômicas desenvolvidas pela SUDENE tem suas bases no caráter autônomo com o qual inicia-se o processo de transição da sistemática de produção subdesenvolvida para a produção as escalas desenvolvidas. A mudança de dinâmica na ótica Furtadiana tenderia a surgir de um contexto 
histórico e social, mas não seria processada. Os fatos econômicos das reformas, desconectados dos fatos sociais e históricos, levariam a superação e a mudanças estruturais. Entretanto, Manoel Correia aponta que, de fato, as mudanças que ocorreriam na região Nordeste teriam como resultado a permanência da estrutura de controle dos recursos produtivos, da posse de terra e por consequência da ênfase nos setores primários exportadores. O que ocorreria, então, em função da interpretação do diagnóstico realizado por Furtado seria a criação de um ambiente econômico, com rodovias, eletrificação e instrumentos governamentais capazes de estimular uma expansão capitalista nas regiões do antigo campesinato nordestino, principalmente nas áreas do Agreste, Sertão, do Meio-norte e da Guiana maranhense. Sobre tal expansão Manoel Correia aponta:

“(...)expansão capitalista era considerada necessária ao Nordeste, que vinha sendo beneficiado com a construção de usinas hidrelétricas, com a abertura de estradas e com a expansão do crédito oficial." (ANDRADE, 1993, p.38)

Outra diferença importante, necessária à consideração ao elaborarem-se políticas econômicas de mudança estrutural é o contexto histórico na qual a economia nordestina esta inserida. A industrialização que se desenrolou a partir da década de 1930 no Sudeste formou o primeiro setor industrial de relevância no país. Já o diagnostico Furtadiano falha ao não levar em conta a origem dos capitais industriais modernizadores que tenderiam a criar um fluxo de lucros de negócios realizados no Nordeste com capital de origem externa à região. Assim, a industrialização visualizada por Furtado teria:

“(...) também a contrapartida. Assim, como os estabelecimentos pertencem, em sua maioria, as empresas do Sudeste ou multinacionais, os lucros obtidos são transferidos e aplicados em outras áreas, não contribuindo assim expressivamente para a acumulação a nível regional;" (ANDRADE, 1993,p.46)

É importante notar que a interpretação de Celso Furtado se alterou desde seu primeiro diagnóstico exposto na obra "A Operação Nordeste" de 1959. As contribuições realizadas pelas políticas da SUDENE seriam, segundo Furtado:

"A novidade da SUDENE foi que ela preparou uma carteira de projetos de emergência. O drama que estamos presenciando é o da falta de renda de uma população miserável, que passa a morrer de fome porque depende, para comer, dessa pequena renda que tem. Isso 
tudo é sabido, conhecido." (FURTADO in TAVARES et al. 1998, $2^{\text {a }}$ Ed. p. 17)

Nota-se com isso que a problemática da pobreza, da fome e do atraso econômico do Nordeste brasileiro tem de ser tratado nos diversos aspectos desses fenômenos, faz se preciso combater os elementos de permanência da estrutura produtiva tanto na esfera econômica como na esfera política e social. Cabe-se então estudar a composição dos planos de ação da SUDENE para averiguar seus limites dentro dessas diversas esferas.

\section{Os Planos Diretores e a Ação da SUDENE: I Plano Diretor (1961 - 1963)}

Partindo das prerrogativas de que o Governo Federal se tornaria a maior esfera pública de atuação no Nordeste, e que haveria perda na eficiência dos investimentos públicos, a SUDENE elaborou seu primeiro Plano Diretor que durou de 1961 a 1963 com o objetivo de estimular a economia nordestina. Diferentemente das regiões Sul e Sudeste, o Nordeste, não mostraria o mesmo ritmo acelerado de desenvolvimento econômico apresentado pelo Plano de Metas, de 1956.

O Plano Diretor de 1961 - 1963 tinha sua abordagem dividida em quatro eixos: (1) a criação e ampliação de infraestrutura econômica, (2) o aumento da oferta de terra e reorganização das posses de terras na região do semiárido, (3) ampliação dos sistemas das bacias hidrográficas e (4) elaboração de uma política de industrialização, para estímulo da absorção de mão de obra e substituição de equipamentos obsoletos.

Os primeiros passos para a criação da infraestrutura econômica concentraram-se no setor rodoviário. Nos anos de 1961 a 1963, somente os gastos nesse setor foram discriminados. Com isso, a SUDENE pretendia conectar os centros de escoamento primárioexportadores - as terras mais remotas do semiárido - intentando um sistema logisticamente mais coeso e que fosse capaz de suprir as demandas do mercado externo. O setor de transporte beneficiou-se, de maneira que:

"Dos investimentos que o governo federal deverá realizar em transportes, no nordeste, apenas os correspondentes ao setor rodoviário foram discriminados no presente plano diretor. Estes últimos alcançam, no quinquênio, 23.132 milhões de cruzeiros, sendo que a contribuição da SUDENE deverá elevar-se a 4.500 milhões. $\mathrm{O}$ programa de pavimentação absorverá cerca de 9,4 bilhões de cruzeiros.” (SUDENE, p. 20, 1966) 
Cabe aqui pontuar a falta de percepção da Superintendência para com as formas das estruturas arcaicas da economia nordestina e da maneira como elas se alastram nas terras do Nordeste, Manoel Correia já apontaria, em 1963, tal descuido:

“(...) é conveniente salientar que a melhoria das técnicas de produção, o aumento da rentabilidade da terra, sem medidas complementares em defesa do trabalhador do campo, até hoje, no Brasil, apenas tem carreado mais dinheiros para os bolsos dos ricos proprietários, continuando os que mourejam a terra a viver nas condições de vida mais precárias.” (ANDRADE,1963, p.229)

O segundo eixo do plano - a ampliação da oferta de terra com reorganização da posse de terras do semiárido -, voltou-se prioritariamente à utilização de novas propriedades rurais na proximidade de açudes e do rio São Francisco. A Tabela 21 traz a composição percentual dos investimento executados pela SUDENE para esses efeitos no período de 1961 a 1963.

Tabela 21. Participação percentual(\%) dos programas de investimento da SUDENE - Ampliação da oferta de terra e reorganização do semiárido.

\begin{tabular}{lrrr}
\hline Discriminação (\%) & 1961 & 1962 & 1963 \\
\hline Ampliação da Oferta de terras & 90,38 & 97,54 & 97,45 \\
A) Bacias de irrigação dos açudes & 65,72 & 82,15 & 82,08 \\
B) Submédio São Francisco & 12,33 & - & - \\
C) Baixo São Francisco & 12,33 & 15,38 & 15,37 \\
\hline & & & \\
Reorganização da Economia da Zona Semiárida & 9,62 & 2,46 & 2,55 \\
A) Algodão Arbóreo & 2,53 & 0,8 & 0,8 \\
B) Mamona & 2,71 & 1,35 & 1,35 \\
C) Oiticica & 0,06 & 0,09 & 0,18 \\
D) Forrageiras & 4,32 & 0,22 & 0,22 \\
\hline
\end{tabular}

Fonte: SUDENE: I Plano Diretor do Desenvolvimento Econômico e Social do Nordeste, Recife, p. 22, 1966

Tais ações teriam como consequência, devido à falta de coesão entre a ampliação e a reorganização, o fortalecimento das atividades econômicas já consolidadas no sertão semiárido. Assim, a própria ação da SUDENE viria a reforçar as estruturas arcaicas da economia da região.

O setor industrial no Nordeste brasileiro na década de 1960 existia de maneira esporádica e intermitente, sendo em sua maior parte representado pela indústria têxtil e de produção de bens de consumo geral. Entretanto, havia um grande potencial para crescimento e desenvolvimento econômicos, devido aos crescentes centros urbanos com grande oferta de 
mão de obra barata. As políticas da SUDENE nessa frente foram de investimento no treinamento de pessoal especializado e elaboração de projetos de investimento.

$\mathrm{Na}$ duração do primeiro plano, a política industrial foi contida pelo processo de pesquisa e agregação de conhecimento quanto aos recursos e mercados das principais cidades produtoras de bens industrializados, por isso não foi investido recursos em novas fábricas mas sim na modernização das plantas já operacionalizadas, com substituição de equipamentos obsoletos e treinamento da mão de obra. A Tabela 22 apresenta os gastos com a política industrial, realizados de 1961 a 1963.

Tabela 22. Investimentos realizados com política industrial - Unidade $=$ Milhões de Cruzeiros

\begin{tabular}{lrrr}
\hline Discriminação (Milhões Cr\$) & 1961 & 1962 & 1963 \\
\hline Indústria têxtil & 15,3 & 15,3 & 2,9 \\
Programa de Treinamento & 6 & 6 & 2 \\
Elaboração de Projetos & 6,5 & $6,5-$ & \\
Estudos para reequipamento & 1 & $1-$ & \\
Despesas gerais & 1,8 & 1,8 & 0,9 \\
Outras indústrias & 15 & 19 & 30 \\
Assistência técnica & 5 & 7 & 10 \\
Elaboração de projetos & 10 & 12 & 20 \\
Reestruturação das atividades & & & \\
artesanais & 5 & 10 & 20 \\
Total & 35,3 & 44,3 & 52,9 \\
\hline
\end{tabular}

Fonte: SUDENE: I Plano Diretor do Desenvolvimento Econômico e Social do Nordeste, Recife, p. 23, 1966

À luz dos dados acima apresentados, pode-se dizer que o teor das primeiras políticas industriais da SUDENE foi passivo, limitando-se a um levantamento primário de dados e à elaboração de propostas iniciais de projetos para serem postos em prática posteriormente. Com a assistência prestada e programada aos proprietários de terras do semiárido os grandes latifundiários passaram a intensificar as tomadas de terra por grilagem, essas terras foram usadas para produção de algodão o qual era a principal matéria prima da indústria têxtil. Dessa forma, os dados sobre os recursos da SUDENE corroboram a assertiva de Manoel Correia, quando esse trata do processo de evolução das relações produtivas capitalistas no campo, dizendo que:

"Com a valorização das terras e da carne, acompanhada de novas gramíneas, resistentes à seca, e da construção de silos e ainda do estímulo à aquisição de concentrados feitos através das políticas de assistência governamental, os fazendeiros ampliaram as áreas a serem 
ocupadas pelo gado expulsaram os agricultores sem terra, que foram forçados a migrar para as grandes e médias cidades." (ANDRADE,2000,p.23)

O último eixo do Plano consistiria em uma proposta de melhorar a condição de vida das populações rurais e urbanas de baixa renda, para isso foram gastos 2,2 bilhões de cruzeiros no quinquênio de 1961 a 1965, com investimentos em saúde infantil e educação primária. Conforme pode ser observado na tabela 23.

Tabela 23. Investimentos com saúde pública e educação básica por esfera pública em milhões de Cruzeiros.

\begin{tabular}{ccccccc}
\hline Discriminação & 1961 & 1962 & 1963 & 1964 & 1965 & Total \\
\hline SUDENE & 310 & 400 & 490 & 500 & 500 & 2.200 \\
\hline $\begin{array}{c}\text { Outros Orgãos } \\
\text { Federais }\end{array}$ & 1.560 & 1.560 & 1.560 & 1.560 & 1.560 & 7.800 \\
\hline Estados & 360 & 360 & 360 & 360 & 360 & 1.800 \\
\hline Municípios & 100 & 150 & 150 & 150 & 150 & 700 \\
\hline Total & 2.330 & 2.470 & 2.560 & 2.570 & 2.570 & 12.500 \\
\hline
\end{tabular}

Fonte: SUDENE: I Plano Diretor do Desenvolvimento Econômico e Social do Nordeste, Recife, p. 28,1966

No quesito de saúde pública o primeiro plano identifica dois problemas fundamentais para serem tratados: a mortalidade infantil e as infecções helmínticas. Para tratar dos dois problemas passou a ser foco dos investimentos públicos as obras de abastecimento de água potável, tendo como objetivo reduzirem a parcela da população que teria de recorrer a fontes de água contaminadas.

Os investimentos em educação básica seriam dedicados a alfabetizar adultos, disseminar novas técnicas da agropecuária já presentes nas demais regiões do país. Além disso, foram avaliados projetos de iniciativa cultural e de formação de cooperativas no campo.

Os resultados desse último eixo do plano foram predominantemente na área de abastecimento de água, tendo sido dedicados $99,92 \%$ do total de recursos. Já os investimentos em educação totalizaram 10 milhões de cruzeiros ou $0,08 \%$ dos recursos. Resultados como esse são exemplos da miopia dos esforços realizados pela SUDENE em seus anos iniciais. Embora houve-se uma iniciativa clara voltada ao melhoramento das condições de vida no Nordeste, as obras realizadas teriam vantagens econômicas de tipo spill-over para as atividades da agropecuária, levariam a permanência de elementos arcaicos no modo de produção da região.

Os resultados das ações descritas no primeiro Plano Diretor podem ser observados na tabela 24. Nela, se mostra a participação setorial para a formação bruta de capital fixo no Nordeste para os anos de 1965 a 1967, ou seja, em tempo de maturação desses investimentos 
na formação de estoques de capital para o crescimento e desenvolvimento econômicos. Nos anos posteriores, devido às alterações realizadas nas diretrizes da SUDENE, houve uma mudança significativa na composição da variável de formação do capital fixo, com maior ênfase nos setores da indústria de transformação.

Tabela 24. Percentual da participação setorial na formação bruta de capital fixo 1965 -1967

\begin{tabular}{lccc}
\hline $\begin{array}{l}\text { Participação do Setor na } \\
\text { Formação Bruta de Capital } \\
\text { Total }\end{array}$ & 1965 & 1966 & 1967 \\
\hline $\begin{array}{l}\text { Agropecuária, Silvicultura e } \\
\text { Pesca }\end{array}$ & $9,52 \%$ & $9,84 \%$ & $12,05 \%$ \\
$\begin{array}{l}\text { Ind. Extrativa Mineral } \\
\text { Ind. de Transformação }\end{array}$ & $9,52 \%$ & $9,84 \%$ & $9,64 \%$ \\
$\begin{array}{l}\text { Energia Elétrica e Abastecimento } \\
\text { de Água }\end{array}$ & $9,52 \%$ & $8,20 \%$ & $12,05 \%$ \\
$\begin{array}{l}\text { Construção } \\
\text { Comércio }\end{array}$ & $11,90 \%$ & $11,48 \%$ & $9,64 \%$ \\
$\begin{array}{l}\text { Transportes, Armazenagem e } \\
\text { Comunicações }\end{array}$ & $2,38 \%$ & $1,64 \%$ & $2,41 \%$ \\
$\begin{array}{l}\text { Atividades Financeiras, Bens } \\
\text { Imóveis e Serviços às Empresas } \\
\text { Serv. Comunitários, Sociais e } \\
\text { Pessoais }\end{array}$ & $28,57 \%$ & $27,87 \%$ & $24,10 \%$ \\
\hline
\end{tabular}

Fonte: Elaborado pelo autor com dados de: SUDENE.:Agregados econômicos regionais do nordeste do Brasil 1965-98,Recife, 1999,p.31-35

Na tabela 24, há predominância da formação de capital nos setores de atividades financeiras, bens e serviços e transporte armazenagem e comunicação. Fato que esta sintonia com os investimentos em infraestrutura planejados pela SUDENE em seu primeiro Plano Diretor, e que demonstra a tentativa inicial da superintendência de criar um ambiente fértil ao desenvolvimento do potencial econômico do Nordeste.

\section{Plano Diretor (1963 - 1965)}

O segundo Plano Diretor, com 95 páginas, divididas em quatro capítulos, deu continuidade às medidas de industrialização. $\mathrm{O}$ seu menor volume se dá em detrimento das ações com infraestrutura que perderam participação no montante de recursos investidos, dando espaço aos valores diretamente alocados na produção e nos pré investimentos. Os recursos totais tiveram aumento absoluto de $347,30 \%$, quando comparados com o I Plano graças, principalmente, aos estudos realizados no triênio anterior. 
A tabela 25 expõe o demonstrativo dos gastos programados no II Plano Diretor, para o período de 1963 a 1965, com as atualizações dos valores de 1963 devidas ao caráter de continuidade do planejamento para a região.

Tabela 25. Investimentos Por Programa de 1963 - 1965 (Milhões de Cruzeiros)

\begin{tabular}{lrrr}
\hline Setor & \multicolumn{1}{c}{1963} & \multicolumn{1}{c}{1964} & \multicolumn{1}{c}{1965} \\
\hline Transporte & 9.779 & 12.965 & 13.856 \\
Eletrificação & 25.409 & 21.136 & 17.964 \\
Levantamento Sistemático e Aproveitamento de Recursos Naturais & 3.856 & 3.916 & 4.250 \\
Reestruturação da Economia Agrícola Desenvolvimento Integrado & & & \\
dos Grandes Vales da região semiárida e Perfuração de poço & 8.401 & 11.070 & 11.140 \\
Política de Industrialização & 1.458 & 1.988 & 2.412 \\
Desenvolvimento da Pesca & 2.060 & 2.150 & 2.341 \\
Racionalização do Abastecimento & 950 & 710 & 730 \\
Ajuda Técnico Financeira ao Artesanato & 50 & 62 & 74
\end{tabular}

Fonte: Elaborado pelo autor com dados de: SUDENE: II Plano Diretor do Desenvolvimento Econômico e Social do Nordeste, Recife, p. 83-95, 1966

Ocorreu um avanço dos dispêndios com os setores de transporte e água potável e esgotos, que representavam 15\% e 12\% dos recursos totais em 1963 passando a englobarem $19 \%$ e $21 \%$ dos mesmos em 1965. Ao mesmo tempo, há decréscimo nos investimentos em eletrificação, os quais passariam de um patamar 30\% no primeiro ano de operação do Plano para $25 \%$, no final do triênio.

Para as despesas com o transporte, é importante notar que a ênfase foi dada aos melhoramentos, pavimentação e obras de arte especiais nas rodovias. Conta essa que chegou aos montantes de $8,8,11,1$ e 12,1 bilhões de cruzeiros, totalizando com isso $90 \%, 86 \%$ e $87 \%$ dos investimentos com transportes.

Em suma, a organização do planejamento no segundo Plano Diretor, de 1964, estava voltada ao estudo e aprimoramento da capacidade produtiva já implantada. As contas intrinsecamente ligada a ampliação de infraestrutura foram desvalorizadas, como foi o caso da produção e distribuição da energia elétrica. Já contas que necessitavam de medidas de manutenção e substituição ganharam prioridade, como por exemplo a conta de gastos com rodovias e os serviços de água potável. Foi predominante o transporte de água para abastecimento e não o aumento capacidade de captação.

Houve, então a coadunação das tendências econômicas regionais, com o segundo Plano Diretor da SUDENE com o PAEG, demonstrando como, na década de 1960, as políticas econômicas nacionais e regionais encontravam-se intrincadas. Consolidou-se a ausência de ações que desenvolvessem maior igualdade de renda e da posse das terras do Nordeste. Noção essa em sintonia com o que Souza apontaria como: 
"Em termos concretos, o PAEG alterou as bases do crescimento econômico brasileiro do sentido do estímulo da demanda efetiva para a concentração de renda e a dependência externa." (SOUZA in PIRES, 2010 p. 162 )

\section{Plano Diretor (1966 - 1968)}

Durante a execução dos planos I e II, foram desenvolvidas pesquisas de levantamento dos recursos naturais e humanos, assim como seus desenvolvimentos potenciais. Isso se reflete no III plano que com três grandes linhas de ação, detalha e programa montantes cada vez maiores de recursos federais. O plano é composto de 134 páginas divididas em dez capítulos de detalhamento dos gastos, mais um capítulo dedicado a lei 4.862 de 1 de dezembro de 1965 que aprova e delimita as competências do III Plano Diretor. Além disso, há também uma sessão de anexos com as tabelas de detalhamento dos programas a serem executado e seus valores. Todo o documento totaliza 185 páginas.

O III Plano seria o primeiro plano com carácter de planejamento de gastos programados sem o teor retroativo que permearia os Planos de 1961 e 1963. Sendo assim temos a tabela 26 que expõe os valores programados aos diversos setores identificados pela SUDENE como fundamentais a promoção do desenvolvimento no Nordeste para o Plano de 1966. Arrematando, então, 743 bilhões de cruzeiros, o que representou um aumento de 363,18\% frente ao Plano de 1964. 
Tabela 26 investimentos por programa em milhões de cruzeiros $(\mathrm{Cr} \$)$

\begin{tabular}{lrrrr} 
Setor & 1966 & 1967 & 1968 & \multicolumn{1}{c}{ Total } \\
\hline Eletrificação & 30.090 & 46.910 & 61.550 & 138.550 \\
Formação de Pessoal & 50 & 200 & 1.000 & 1.250 \\
Rodovias & 22.515 & 35.500 & 50.500 & 108.515 \\
Hidrovias & 2.645 & 3.300 & 4.400 & 10.345 \\
Comunicação & - & 500 & 1.000 & 1.500 \\
Abast. de Água e Esgoto & 19.070 & 31.890 & 47.820 & 98.780 \\
Recursos Naturais & 12.000 & 18.000 & 25.000 & 55.000 \\
Recursos Humanos & 8.130 & 19.200 & 27.150 & 54.480 \\
Treinamento & 700 & 1.500 & 2.400 & 4.600 \\
Saúde & 3.240 & 9.805 & 16.010 & 29.055 \\
Habitação e Ação Comunitária & 2.420 & 4.300 & 5.250 & 11.970 \\
Mercado agrícola & 2.100 & 3.300 & 5.000 & 10.400 \\
Reestruturação Agrícola & 6.900 & 14.200 & 22.200 & 43.300 \\
Matéria prima industrial & 8.000 & 13.500 & 18.000 & 39.500 \\
Projetos Industriais & 2.000 & 10.850 & 19.000 & 31.850 \\
Auxilio Finan. Peq. e Méd. Indústria & 570 & 7.800 & 13.100 & 21.470 \\
Desenvolvimento do Vale do Jaguaribe & 2.100 & 2.900 & 3.500 & 8.500 \\
Submédio do São Francisco & 2.200 & 2.900 & 3.500 & 8.600 \\
Desenvolvimento da Pesca & 5.700 & 9.200 & 11.000 & 25.900 \\
Coordenação da SUDENE & 10.000 & 13.500 & 16.000 & 39.500 \\
\hline Total & 140.430 & 249.255 & 353.380 & 743.065 \\
\hline Fon Enaborat
\end{tabular}

Fonte: Elaborado pelo autor com dados de: SUDENE: III Plano diretor do desenvolvimento econômico e social do nordeste, Recife, p. 155 - 183, 1966.

Para o terceiro Plano Diretor, há ainda a predominância dos projetos de eletrificação, abastecimento de água e esgoto e construção e manutenção de rodovias, representando, respectivamente, $18,65 \%, 13,29 \%$ e $14,60 \%$ do total de investimentos programados. É importante observar também as ações com maiores aumentos, sendo essas auxilio financeiro a peque e média indústrias e os gastos com pesquisas e estudos dos recursos humanos, o primeiro passando de 570 milhões de cruzeiros em 1966 para 13,1 bilhões em 1968. Já o segundo passaria de 12 bilhões em 1966 a para 25 bilhões em 1968.

O Plano Diretor de 1966, assim, preservaria as formas dos Planos de 1961 e 1963 com aumentos nos esforços de auxílios financeiros às pequenas e médias indústrias e no levantamento e estudo do potencial dos recursos humanos do Nordeste.

IV Plano Diretor (1968 - 1973)

O Plano de 1968 compôs-se de nove capítulos mais anexos, totalizando 366 páginas agrupadas em duas partes, sendo a primeira dedicada ao detalhamento das ações do plano e a segunda trazendo a lei 5.508 de 11 de outubro de 1968 autorizando e delimitando as 
competências da superintendência no seu quarto Plano. Os valores encontrados no Plano tem como unidade de monetária o cruzeiro novo (NCr\$) de 1968.

Tabela 27 investimentos por programa em milhões de cruzeiros novos ( $\mathrm{NCr} \$$ )

\begin{tabular}{|c|c|c|c|c|c|c|}
\hline Setor & 1969 & 1970 & 1971 & 1972 & 1973 & Total \\
\hline Eletrificação & 42.325 & 48.900 & 54.630 & 73.100 & 94.920 & 313.875 \\
\hline Rodovias & 31.300 & 41.900 & 39.500 & 38.700 & 45.300 & 196.700 \\
\hline Sistema Portuário & - & & 500 & 500 & 500 & 1.500 \\
\hline Telecomunicações & 200 & 300 & $500-$ & - & & 1.000 \\
\hline \multicolumn{7}{|l|}{ Abast. de Água e } \\
\hline Esgoto. & 21.490 & 25.980 & 28.420 & 34.540 & 38.640 & 149.070 \\
\hline Abast. Agricola & 8.320 & 8.920 & 12.780 & 18.400 & 20.480 & 68.900 \\
\hline Educação & 5.737 & 9.565 & 20.847 & 23.136 & 29.627 & 88.912 \\
\hline Indústria & 10.850 & 12.430 & 15.660 & 12.700 & 14.300 & 65.940 \\
\hline Recursos Naturais & 16.480 & 19.990 & 28.580 & 33.985 & 31.905 & 130.940 \\
\hline Saúde & 2.570 & 3.570 & 5.946 & 7.632 & 9.982 & 29.700 \\
\hline Habitação & 1.510 & 1.952 & 3.000 & 3.750 & 4.786 & 14.998 \\
\hline \multicolumn{7}{|l|}{ Programações } \\
\hline Especiais & 4.564 & 7.448 & 10.428 & 15.010 & 17.700 & 55.150 \\
\hline Administração & 19.000 & 19.000 & 22.800 & 27.400 & 32.900 & 121.100 \\
\hline Total & 164.346 & 199.955 & 243.591 & 288.853 & 341.040 & 1.237 .785 \\
\hline
\end{tabular}

Fonte: SUDENE. IV Plano Diretor do Desenvolvimento Econômico e Social do Nordeste, Recife, p. 331 - 347 , 1968.

Com o Plano de 1968, reverteu-se a tendência de queda da participação dos investimentos com eletrificação, aumentando a participação para $25,36 \%$ dos recursos totais do Plano, com crescimentos constantes de 1969 a 1973. Os investimentos programados com construção e manutenção de rodovias apresentariam, mesmo com quedas nos anos 1971 e 1972, aumento da participação dos investimentos totais chegando ao patamar de $15,89 \%$ do total.

O programa que viria a perder participação foi o de abastecimento de água e esgotos. Embora sofresse constantes aumentos nos anos de 1970, 1971, 1972 e 1973, esses se mostrariam insuficientes e o programa passaria a representar $12,04 \%$ do total dos recursos, em contrapartida no Plano de 1966 o mesmo abrangia 13,29\%.

Outro ponto importante do IV Plano foi a elaboração dos programas especiais de reforma da administração pública do Nordeste e de racionalização da agroindústria canaveira do Nordeste, o primeiro que seria uma tentativa de aumentar a eficiência da ação pública das 
esferas estaduais e municipais em prol do crescimento econômico e viria a ignorar o caráter político de tal empreitada, focando no treinamento de pessoal.

Já o programa de racionalização da agroindústria canaveira visava a modernização do setor com treinamento de pessoal, financiamento na compra de equipamentos e incentivos a utilização de novas variedades de cana. Esse programa viria a movimentar nos 5 anos do plano 153,5 bilhões de cruzeiros novos, sendo que desse 33,5 bilhões seriam da SUDENE e 120 bilhões do fundo de racionalização da agroindústria canavieira. Com esse novo programa o setor sucroalcooleiro passaria por um processo de concentração da oferta com fusões e compras de usinas de pequeno e médio porte.

\section{Algumas Considerações}

O impacto das novas diretrizes da SUDENE viria ser o fortalecimento das dependências de diversos setores da economia nordestina para com o mercado exterior. Os Planos Diretores construíram uma infraestrutura complementar as atividades econômicas tradicionais da região. Faltando nessa medida ações voltadas a tratar da forma com que os elementos arcaicos reagiriam a estímulos externos causados pelo governo. $\mathrm{O}$ aumento da oferta e terra e do acesso aos mercados consumidores realizados de maneira a promover uma economia capitalista integrada com as demais regiões do Brasil necessitaria de coordenação social das forças proletárias para evitar os que benefícios socioeconômicos sejam tomados pelos herdeiros das oligarquias tradicionais consolidadas no Nordeste desde de seus primórdios coloniais.

Para além dos problemas de desigualdade social, os planos falharam em contemplar os efeitos que a reestruturação da economia agroindustrial teria para com o meio ambiente. Nos quatro planos não se pode encontrar nenhum programa de preservação dos recursos florestais e hídricos do Nordeste, de fato, há um conjunto de programas voltados a financiar projetos privados de utilização de novas terras. Sobre tais programas, Manoel Correia apontava:

"E toda a devastação é feita com incentivos governamentais, fornecidos em nome do desenvolvimento e fortalecimento do sistema capitalista(...)" (ANDRADE, 1994a, p.43)

Então, é possível afirmar que a hipótese de Manoel Correia sobre o desenvolvimento da SUDENE em sua relação com a política e a economia do Nordeste se confirma. Apesar de seu caráter aparentemente progressista no início, o órgão foi incorporado pelo sistema de reprodução da dominação oligárquica dos detentores dos meios produtivos no Nordeste. Como vários órgãos da burocracia administrativa do Estado Patrimonialista implantado no Brasil desde sua independência, em 1822, a SUDENE se tornaria progressivamente um órgão 
reverberador do pensamento da classe dominante, e um depósito do resultado da formação tecnocrática de seus quadros, sobretudo a partir de 1966, com a reforma política e administrativa do Estado promovida pelo Plano de Ação Econômica Geral imposto pela Ditadura Militar. 


\section{Conclusão}

Manoel Correia de Andrade apresentou volume e substância superlativos em sua contribuição ao pensamento brasileiro. As hipóteses estudadas nessa pesquisa dão o tom da obra de Andrade, que com uma gama de mais de 130 publicações, escreveu sobre as diversas facetas da sociedade nordestina sempre focando nas organizações econômicas em suas regiões de operação e dos impactos sobre as condições de vida das populações do Litoral Ocidental, do Agreste, do Sertão e do Meio Norte. Sua vida acadêmica se estendeu da década de 1940 até a primeira metade década de 2000 . Nesse tempo as ciências sociais passaram um processo de convergência, tendo cientistas da história, da economia, da geografia humana disseminado a noção de que nos transbordamentos das ciências há um grande valor descritivo e interpretativo capaz de oferecer uma visão mais compreensivas do desenvolvimento das sociedades de forma ampla.

É nos transbordamentos das geografia que Andrade prospera. Partindo da geografia humana, o autor construiu em seu livro "A Terra e o Homem No Nordeste" o modo de ver o Nordeste na evolução dos espaços econômicos das atividades dominantes e suas consequências sobre as populações de suas sub-regiões. Os debates nos quais o conjunto da obra de Andrade encontra-se inserido se dão pelo contexto dos avanços na geografia, na economia e na história, tendo diversos pontos similares no tratamento de temas como a formação da economia açucareira, do êxodo rural e das tentativas de superação do subdesenvolvimento, que outros autores como Caio Prado, Celso Furtado, Francisco de Oliveira, Josué de Castro, Capistrano de Abreu. Porém, frente a esses autores, e mesmo a outros mais, há uma singularidade em uma divergência fundamental de Andrade no trato da economia nordestina, a saber, a importância das espacialidades na organização econômica das sociedades nos momentos históricos do Nordeste.

Andrade ocupa um lugar importante na historiografia econômica no Nordeste fazendo a ponte entre a geografia econômica e a história econômica em debates como: (I) O papel das cidades no desenvolvimento região, (II) a natureza do domínio e uso das terras no nordeste e (III) dos entraves ao desenvolvimento econômico do Nordeste. Sendo esses temas não só importantes para entendimento da histórica econômica do Nordeste mas também para o diagnostico de problemas atuais nas estruturas produtivas modernas. 
Quanto à territorialidade das atividades dominantes do Nordeste, as principais contribuições de Andrade são aquelas referentes à conceituação do "Mosaico Nordestino", ou seja da formação de regiões economicamente definidas que não se sobrepõem umas às outras, e cujos limites são definidos pelos territórios das atividades dominantes. Tais atividades criariam uma estrutura político-social que as imbuiriam com capacidade de adaptação a choque externos, mantendo o status quo regional e reproduzindo as formas arcaicas de produção, mesmo em atividades com maquinário e infraestrutura modernas.

$\mathrm{Na}$ hipótese das territorialidades das atividades dominantes reside um dos problemas que Manoel Correia aponta como de fundamental superação. Para realizar-se mudanças estruturais "reais", esse problema seria a concentração fundiária na mão dos grandes latifúndios. O uso das terras do Nordeste deriva historicamente de uma estrutura de concentração das terras que impede o melhor funcionamento da economia agrícola, limitando a organização dos espaços econômicos a uma configuração de subutilização, com os resultados econômicos de depreciação, ociosidade de capacidade produtiva e subdesenvolvimento crônico.

Sempre preocupado com o estudo da condição de vida nas regiões rurais, Andrade elabora sua segunda hipótese central sobre o crescimento das cidades, sendo tal crescimento um fenômeno determinado pela transição de um antigo modelo de produção que exploraria o trabalho de forma extensiva para um modelo que exploraria o trabalho rural de maneira intensiva. Assim a modernização da agricultura que transpareceu nas décadas de 1970, 1980 e 1990 criaria um fluxo de migração para as cidades que seriam incapazes de propriamente recebê-los o que geraria um crescimento desordenado.

A natureza da segunda hipótese reside no desequilíbrio entre os espaços urbanos e rurais. As contribuições de Andrade novamente voltariam à forma de se observar os espaços no tempo. Se na primeira hipótese, há uma ênfase nos territórios das atividades econômicas, nessa segunda hipótese, ganham significância as dinâmicas dos espaços rurais e urbanos. Com a reconfiguração das zonas rurais, os espaços econômicas urbanos se tornaram mais densos e menos eficazes na alocação dos trabalhadores.

Há, ainda, a hipótese de Andrade quanto à ineficácia das tentativas de superação do subdesenvolvimento que transcorreram posteriormente à criação da SUDENE. Sobre essas, Andrade partiu em 1963 de uma visão otimista mas cautelosa quanto à capacidade dos planos diretores da Superintendência de realizar as políticas agrárias ali descritas, passando em obras 
posteriores como "O Nordeste e a Questão Regional" a considerar as ações realizadas ineficazes como forma de gerar mudanças fundamentais na estrutura agrária, aspecto basilar da superação do subdesenvolvimento, como se deriva das hipóteses anteriores, inclusive.

Os limites das políticas desenvolvimentistas da SUDENE em seus planos diretores estavam diretamente ligados à capacidade que a esfera política e econômica regional teria na assimilação de estímulos externos. Essa condição permitiria a incorporação de iniciativas de modernização agrícola, e incentivo a construção de infraestrutura passando ao largo da consolidação de mudanças estruturais na distribuição da posse de terras, base dos meios de produção, o que poderia ameaçar a hegemonia política das classes dominantes.

Por fim, cabe levar em consideração as propostas de Andrade, um acadêmico que por grande parte de sua vida lutou por uma reforma agrária inclusiva, que propiciasse uma melhor organização dos estabelecimentos rurais e um ambiente onde a vida humana, mesmo com as dificuldades encontradas no polígono das secas, fosse capaz de prosperar. Essa meta seria de difícil obtenção, devido a uma herança retrógrada de estrutura persistente e incapaz de sustentar crescimento econômico de longo prazo, tendo momentos esporádicos e irregulares de enriquecimento, ligados diretamente a fatores externos e direcionados a uma pequena parcela da população. Superar essas estruturas significa hoje, como significou em 1963, transformar os espaços e territórios do Nordeste para alterar os rumos históricos que ainda nos mantém no subdesenvolvimento. A ruptura desse ciclo permanece sendo uma condição presente. 


\section{Referencial Bibliográfico}

ABREU. C. De: Capítulos de História Colonial. São Paulo, Itatiaia, $7^{\text {a }}$ Ed. 2000 (Originalmente publicado em 1907)

: Caminhos antigos e povoamento do Brasil. Edição da Sociedade Capistrano de Abreu. Rio de Janeiro: Briguiet, 1930.

ANDRADE, M. C. de.; ANDRADE, S. M. C. De.; A federação Brasileria; Uma Análise Geopolitica e Geo-social, São Paulo, Contexto, 1999.

ANDRADE, M. C. De: A Agroindústria Canavieira e a Organização do Espaço: Contribuição à História das Usinas de Açúcar de Sergipe. Natal, Cooperativa Cultural Universitária do Rio Grande do Norte, 1990.

:A Questão do Território no Brasil. São Paulo, HUCITEC, $2^{\mathrm{a}}$ Ed. 2004(Originalmente publicado em 1995).

: Lutas Camponesas no Nordeste. São Paulo, Ática, 1986.

:A Questão Nacional e os Desequilibrios de Desenvolvimento

Regional. Recife, UFPE, 1997.

:A Questão do Território no Brasil. São Paulo, Hucitec, $2^{\mathrm{a}}$ Edição 2004(Originalmente publicado em 1995).

de Geógrafos Brasileiros, 1972.

:A Indústria Vinheira no Sul de Minas Gerais. São Paulo, Associação :A Terra e o Homem no Nordeste. Recife, Editora da UFPE, $6^{\mathrm{a}}$ Ed. 1998.

:A Terra e o Homem no Nordeste. São Paulo, Brasiliense, $1^{\text {a }}$ Ed. 1963.

:A Terra e o Homem no Nordeste. São Paulo, Cortez, 8ªd. 2011.

:Abolição e Reforma Agrária. São Paulo, Ática, 1987.

:Área do Sistema Canavieiro. Recife, SUDENE, 1988(a)

:Áreas de domínio da pecuária extensiva e semi-intensiva na Bahia e

norte de Minas Gerais, Recife, SUDENE, 1982.

:As Alternativas do Nordeste. Recife, UFPE, 1983.

:Aspectos Geográficos do Nordeste. Recife, SUDENE, 1966

Geógrafos Brasileiros, 1961

:Aspectos Geográficos da Região de Ubá. São Paulo, Associação dos

:Classes Sociais e Agricultura no Nordeste. Recife, FUNDAJ, 1985

:Cidade e Campo no Brasil. São Paulo, Brasiliense, 1974.

:Espaço, Polarização e Desenvolvimento. São Paulo, Brasiliense, $2^{\mathrm{a}}$

Ed. 1970 (Originalmente publicado em 1967)

:Formação Territórial e Econômica do Brasil.Recife, Massagana,

2003.

:Geografia Econômica Do Nordeste: O Espaço e a Economia

Nordestina. São Paulo, Atlas, $1^{\mathrm{a}} \mathrm{Ed} .1970$

:Geografia Econômica. São Paulo, Atlas, 5ªd. 1976

:Geografia, Região e Desenvolvimento: Introdução ao estudo do Aménagement du Territoire. Cadernos do Instituto de Ciências Políticas e Sociais, Recife, 1967.

:História das Usinas de Açúcar de Pernambuco. Recife, FUNDAJ, 1989.

:História Econômica e Administrações no Brasil. São Paulo, Atlas, 1976.

:Imperialismo e Fragmentação do Espaço; Revolução Industrial e

Imperialismo Descolonizado, a Problemática do Mundo Atual. São Paulo, Contexto, 1991.

:João Alfredo, Estadista da Abolição. Recife, FUNDAJ, 1988(b). 
Cidades, 1980.

:Latifúndio e Reforma Agrária no Brasil. Rio de Janeiro, Duas

:Lutas Camponesas no Nordeste. São Paulo, Ática, 2000

:Modernização e Pobreza. São Paulo, Unesp, 1994a.

:Nordeste, Espaço e Tempo. Petrópolis, Vozes, 1970.

:O Brasil e a América Latina. São Paulo, Contexto, 4ª Ed. 1994b

:O Homem e a Cana-de-açúcar no Vale do Siriji. Recife, Museu do

Açúcar, 1967.

:O Nordeste e A Questão Regional. São Paulo, Ática.

1993(Originalmente publicado em 1988).

:O Sentido da Colonização. Recife, Comunicação e Editora, 1994

:Os Rios do Açúcar Nordeste Oriental: O Rio Mamanguape.Recife,

Fundação Joaquim Nabuco. 1957

:Os Rios do Açúcar do Nordeste Oriental: Os Rios Coruripe, Jiquiá e

São Miguel. Recife, Instituto Joaquim Nabuco de Pesquisa Sociais, 1959.

:Poder Político e Produção do Espaço. Recife, FUNDAJ, 1984

:Polarizações para João Pessoa. Recife, UFPE, 1975

:Uma Releitura Crítica da Obra de Josué de Castro. In Josué de

Castro e o Brasil, Fundação Perseu Abrano, 2003.

:Três Ensaios Sobre a Realidade Nordestina. Recife, Universidade

Católica de Pernambuco, 1967.

:Recife, Uma Trajetória Secular. Recife, UFPE, 2003

:Usinas de açúcar e destilarias no Rio Grande do Norte e na

Paraíba: agro-indústria canavieira e a produção do espaço. Mossoró, ESAM, 1988.

ALVES, L. R. A.; BACCHI, M. R. P.: Oferta de Exportação de Açúcar do Brasil. RER, Rio de Janeiro, vol. 42, n. 01, p. 09-33, jan/mar 2004.

ARRUDA, J. J. De A.: Historiografia Teoria e Prática. São Paulo, Alameda, 2014.

BARBOSA, W. Do N: História Econômica Como Disciplina Independente. Departamento de História, FFLCH-USP, 1988

:O Lugar da História Econômica Entre as Ciências Sociais. Revista

de Economia Política e História Econômica, São Paulo, Número 18, ano 06, p. 125 a 172, Agosto 2009.

15, n.2, p.176-199, 2004.

:Relembrando a Formação da Cepal. Pesquisa e Debate, São Paulo, v.

CARDOSO, C. F.; BRIGNOLI, H. P.:Os Métodos da História. São Paulo, Graal, $6^{\mathrm{a}}$ Ed. 2002( Originalmente publicado em 1976).

CARDOSO, F. H.: Mudanças Sociais na América Latina.. São Paulo, Difusão Europeia do livro, 1969.

CASTELLS, M.: A Questão Urbana. São Paulo, Editora Terra e Paz,1ª Reimpressão 2000 (Originalmente Publicado em 1983)

CASTRO, J. de.: Geografia da Fome. Rio de Janeiro, Antares, 10ª Ed. 1984(Originalmente publicado em 1946).

CARVAlHO, C. P. de O.: Manoel Correia de Andrade e a Economia Política do Nordeste. Revista Econômica do Nordeste, Fortaleza, v. 45, n. 2, p. 6-16, abril/jun., 2014

CAVALCANTI, J. S. B.; MOTA, D. M da; SILVA, P. C. G. da.:Transformações Recentes nos Espaços de Fruticultura do Nodeste do Brasil, em Difusão do agronegócio e novas dinâmicas socioespaciais. Fortaleza: Banco do Nordeste do Brasil, p. 117 - 149, 2006.

CIRO, F. C.; VAINFAS, R.: Novos Domínios da História. Rio de janeiro, Elsevier, 2012.

Cholley, A.: La Géographie, Guide de l'étudaint. Presses Universiteire de France, Paris, 1942. 
CUNHA, E. Da.: Plano De Uma Cruzada, in Euclides da Cunha: Obra Completa em dois Volumes. Rio de Janeiro, Nova Aguilar, 2 ${ }^{\text {a }}$ Ed. 1995(a) p. 153 - 164

Os Sertões. São Paulo: Três, 1984. Disponível em:http://www.dominiopublico.gov.br/download/texto/bv000091.pdf （ Originalmente publicado em 1902).

DINIZ, C.: Desenvolvimento Poligonal no Brasil: Nem Concentração, Nem Continua Polarização. Nova Economia, Belo Horizonte, 1993.

ELDRIDGE, H. T.: The Process of Urbanization. In Demographic Analyses, Glencoe, Free Press, 1956 p. $338-343$

IBGE, Censo Demográfico 2010: Caracteristicas da População e dos Domicílios, Resultados do Universo, Rio de Janeiro, 2011 Disponível em: https://biblioteca.ibge.gov.br/visualizacao/periodicos/93/cd_2010_caracteristicas_populacao_ domicilios.pdf

FERREIRA, W.: Política Externa do Governo Lula: Coalizões Ao Sul Como Alternativa Multilateral. REVISTA DEBATES, Porto Alegre, v.3, n.1, p. 100-125, jan.-jun. 2009.

FONTENELE, R. E. S.:Cultura do Coco No Brasil: Caracterização do Mercado Atual e Perspectivas Futuras,XLIII Congresso Da Sober, Ribeirão Preto, Julho de 2005

FONTES, H. R.; WANDERLEY, M.: Situação Atual e Perspectiva para a Cultura do Coqueiro no Brasil. EMBRAPA, Aracaju, Vol. 94, p. 1 - 16 Novembro 2006

FURTADO, C.:A Fantasia Organizada. Rio de Janeiro, Paz e Terra, 1985.

Brasileiros, 1959.

:A Operação Nordeste. Rio de Janeiro, Instituto Superior de Estudos

:Formação Econômica do Brasil. São Paulo, Companhia Editora Nacional, 32

Ed. 2005(Originalmente publicada em1959).

GIRÃO, R.: História Econômica do Ceára. Fortaleza, Instituto Ceára, 1947.

:Pequena história do Ceará. Fortaleza: A. Batista Fontenelle, 1953.

HARTSHORNE, R.: Questões sobre a Natureza da Geografia. Intituto Pan-americano de Geografia e História, Rio de Janeiro, 1969.

LANGEVIN, M.: Será que as Laranjas e a Cana-de-Açúcar da Flórida Azedam o Livre Comércio? Uma Análise de Ratificação de Nível II da Política Comercial dos Estados Unidos com o Brasil. Contexto Internacional. Rio de Janeiro, vol. 28, no 1, janeiro/junho 2006, pp. 167-221.

LIMA, M. de Oliveira. Formação Histórica da Nacionalidade Brasileira. Rio de Janeiro: Topbooks, $3^{\text {a }}$. Ed. 2000.

MAFIOLETTI, R.: Produção de Etanol Nos Estados Unidos Da América. Revista Política Agrícola, No 3 - Jul./Ago./Set. 2011.

MARINI, R. M.: Sous-Développement et Révolution en Amérique Latine.Paris. Librairie Maspero, 1972.

MARX, K.; ENGELS, F.: Manifesto Comunista, São Paulo, Boitempo,4a reimpressão, 2005 (Originalmente publicado em 1848).

:O Capital. Livro I, Tomo 2. Coleção: Os Economistas. São Paulo: Nova Cultural. 1996(Originalmente publicado 1867)

MELLO, J. A. G. De: Tempo dos flamengos: influência da ocupação holandesa na vida e na cultura do Norte. Rio de Janeiro, José Olympio. 1947.

NOVAES, J. R. P.: Modernização, Relações de Trabalho e Poder. Um Estudo das Transformações Recentes na Agroindústria Canavieira do Nordeste. 1993, 294f, Tese de Doutorado, Universidade Estadual de Campinas, Campinas, 1993.

NUN, J.: Marginalidade y Exclusión Social. Buenos Aires, Fondo de Cultura Económica, 2001 
OLIVEIRA, A. F. de M. et al.:Competitividade Internacional das Exportações de Açúcar no Período de 1991- 2014. FACEF Pesquisa: Desenvolvimento e Gestão, v.20, n.1 - jan/fev/mar/ abr 2017.

OLIVEIRA, F. de.: Noiva da Revolução; Elegia para uma Re(li)gião: SUDENE, Nordeste: Planejamento e Conflitos de Classe. São Paulo, Boitempo, 2008.

PERROUX, F.: L'economie du Xxe siècle, Fontaine, Presses Universitaires de Grenoble, 1991 (Originalmente publicado em 1961).

PLANCHEREL, A. A.; ALBUQUERQUE, C. F.; MELO, S. R. G. DOS S.:Trabalho na agroindústria açucareira de Alagoas. Latitude, Vol. 1, n²2, pp.119-134, 2007.

PRADO JÚNIOR, C..: Formação do Brasil Contemporâneo. São Paulo, Brasiliense,10a reimpr. 23 Ed. 2007(Originalmente publicada em 1942).

:História Econômica do Brasil, São Paulo, Brasiliense, 1956

Brasiliense, 1960.

:Contribuição para análise da questão agrária no Brasil. São Paulo,

RAMOS, P.:Os Mercados Mundiais de Açúcar e a Evolução da Agroindústria Canavieira do Brasil Entre 1930 e 1980: Do Açúcar ao Álcool para o Mercado Interno. Economia Aplicada São Paulo, v. 11, n. 4, p. 559-585, Outubro-Dezembro 2007.

SANTOS, M.:A Urbanização Desigual. São Paulo, Edusp, $3^{\text {a }}$ ed, 2012(Originalmente publicado em 1980).

:Da Totalidade ao Lugar. São Paulo, Edusp, 2005, Capítulos I, II, III, IV, V, VI(Originalmente publicado em: SANTOS, M.: Espaço e Sociedade: Ensaios. Petrópolis, Vozes, 1979.)

:Economia Espacial: Criticas e Alternativas. São Paulo. HUCITEC, 1979.

:Pobreza Urbana. São Paulo, HUCITEC, 1978.

SANTOS, T. dos.: Economia Mundial: Integração Regional e Desenvolvimento Sustentável. Petrópolis, Vozes, $2^{\text {a }}$ Edição, 1994.

SCHUMPETER, J. A.: Teoria do Desenvolvimento Econômico: Uma Investigação Sobre Lucros, Capital, Crédito, Juro e o Ciclo Econômico. São Paulo, Nova Cultural, 1997(Originalmente publicado em 1911).

SIMONSEN, R. História Econômica do Brasil (1500 - 1820). 8a. Edição, São Paulo, Companhia Editora Nacional, 1978 (1941).

SINGER, P.: Economia Política da Urbanização. São Paulo, Brasiliense, 1973.

SILVA, M. A. de M.: Errantes do fim do século. São Paulo: Fundação da Editora da UNESP, 1999.

SILVEIRA, A. M.:A Relação Entre Preços de Açúcar Nos Mercados Doméstico e Internacional. 2004, 89f, Dissertação de Mestrado - Universidade de São Paulo(USP), Piracicaba, 2004.

SOARES, A. R.: Formação Histórica e o Papel do Setor Estatal da Economia Brasileira. São Paulo, Lume, 1991.

SOUZA, L. E. S. de.: A Arquitetura de uma Crise: História e Política Econômica na Argentina, 1989 - 2002. 2007. 325f, Tese de Doutorado - Universidade de São Paulo, São Paulo, 2007. : Elementos de Demografia Econômica. São Paulo, $1^{\text {a }}$ Ed. 2006. :A Ditadura Militar e o PAEG in: PIRES, M. C. (org.) Economia Brasileira: da Colônia ao Governo Lula, São Paulo, Saraiva, $1^{\text {a }}$ Edição, , 2010.

SUPERINTENDÊNCIA DO DESENVOLVIMENTO DO NORDESTE: I Plano Diretor de Desenvolvimento Econômico e Social do Nordeste 1961-1963, Recife, 1966.

:II Plano Diretor de

Desenvolvimento Econômico e Social do Nordeste 1963 -1965, Recife, 1966. 
:III Plano Diretor de

Desenvolvimento Econômico e Social do Nordeste 1966 - 1968, Recife, 1966.

:IV Plano Diretor de

Desenvolvimento Econômico e Social do Nordeste 1969 - 1973, Recife, 1968

:Catálogo dos

Trabalhos Publicados Sobre Recursos Naturais. Recife, 1990.

:Catálogo de

Publicações Editadas pela SUDENE 1959 - 1994. Recife, 1994.

TAVARES, M. da C.;ANDRADE, M. C. de.; PEREIRA, R. R.: Seca e Poder: Entrevista com Celso Furtado. São Paulo. Fundação Perseu Abrano, 2a Ed. 1998.

TRICHES, D. Et al.:Análise do Desempenho das Exportações Brasileiras de Açúcar, No Periodo 1995-2008, e as Restrições Da União Européia. SOBER, Campo Grande, 2009.

WANDERLEY, Maria de Narareth B. Capital e Propriedade Fundiária na Agricultura Brasileira. Rio de Janeiro: Paz e Terra, 1979.

VARNHAGEN, F. A. de. Historia Geral do Brazil isto é do seu descobrimento, colonisação, legislação, desenvolvimento, e da declaração da independencia e do imperio, escripta em presença de muitos documentos inéditos recolhidos nos archivos do Brazil, de Portugal, da Hespanha e da Hollanda. Rio de Janeiro: Laemmert, dois tomos, 1857.

VIANNA, O. Populações Meridionais no Brasil. Rio de Janeiro: Companhia Editora Nacional, 1918.

Sites:

www.ibge.gov.br

http://www.ipeadata.gov.br

www.bnb.gov.br

http://www.factfish.com

www.atlas.media.mit.edu

www.novacana.com 


\section{ANEXOS}

ANEXO 1 - MAPA DA PRODUÇÃO DE CANA-DE-AÇÚCAR NO NORDESTE - 2006

\section{G9IBGE}

Produtos da lavoura temporária - Cana-de-açúcar - Quantidade produzida

Unidade: Toneladas

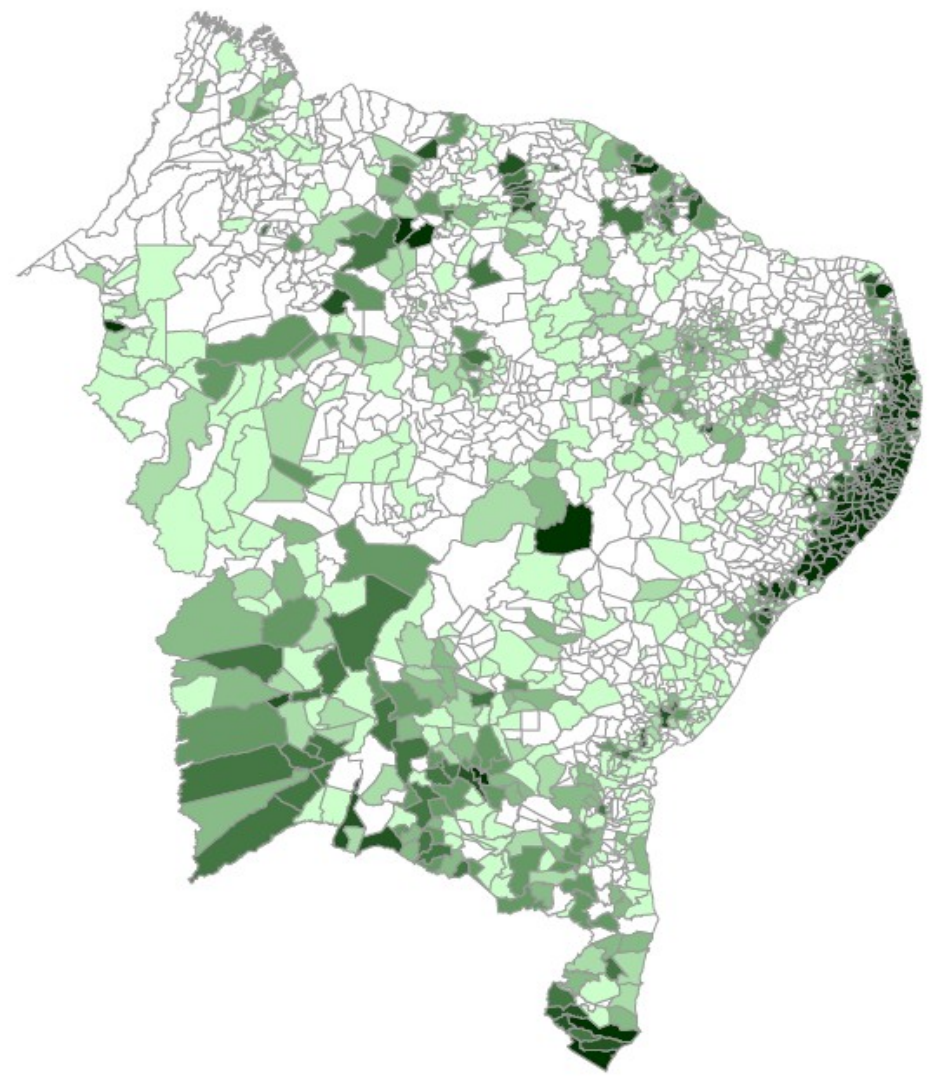


ANEXO 2 - MAPA DAS TERRA UTILIZADAS PARA PASTAGEM NO NORDESTE -

\section{B9IBGE}

Utilização das terras - Pastagens - naturais - Área dos estabelecimentos agropecuários

Estados: MA, PI, CE, RN, PB, PE, AL, SE, BA

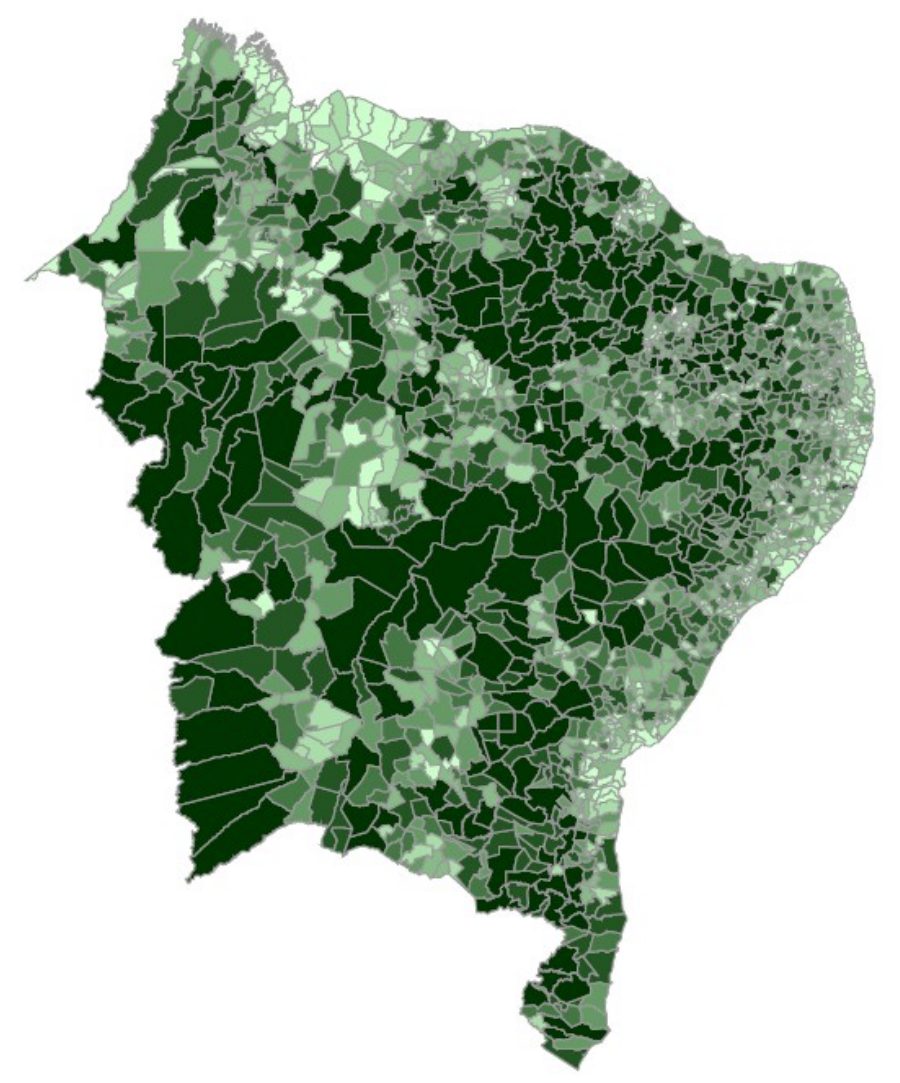

17.968 a 147.252

Ausência de valor 
ANEXO 3 - MAPA DA DISTRIBUIÇÃO DOS REBANHO BOVINOS NO NORDESTE -

\section{GIBGE}

Espécie de efetivo - Bovinos - Número de cabeças

Unidade: Cabegas

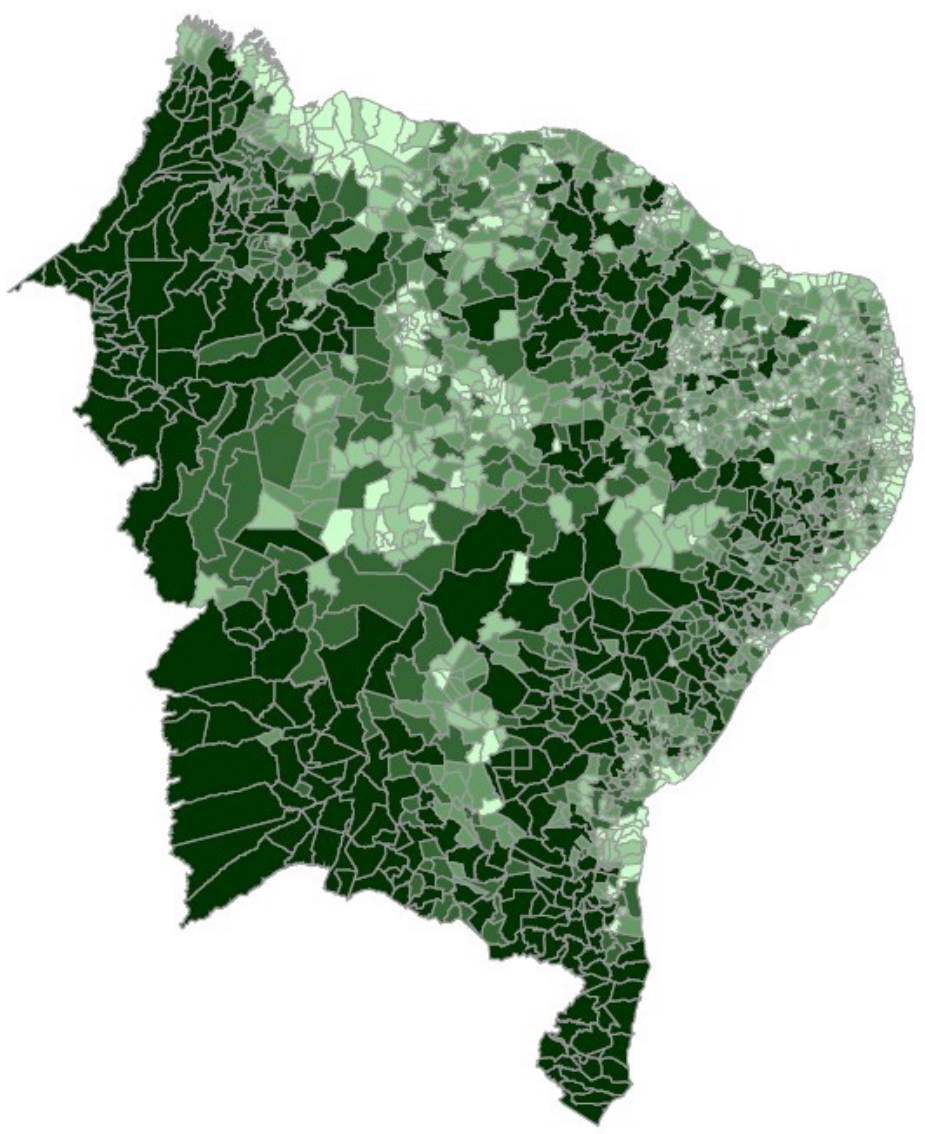




\section{B9IBGE}

Espécie de efetivo - Caprinos - Número de cabeças

Untados: MA, PI, CE, RN, PB, PE, AL, SE, BA

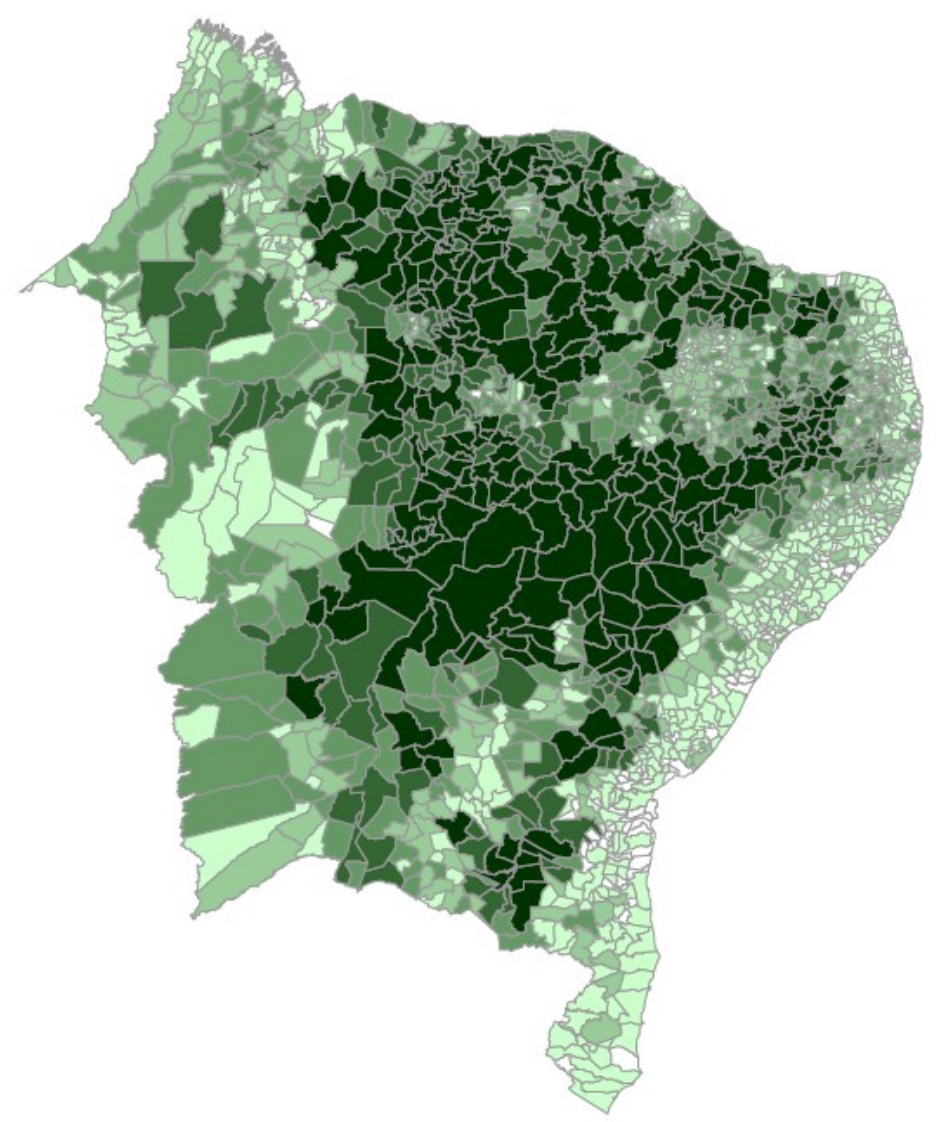


ANEXO 5 - MAPA DA DISTRIBUIÇÃO DO EFETIVO DE AVES NO NORDESTE -

\section{GIBGE}

Espécie de efetivo - Aves - Número de cabeças

Unidade: Mil cabeças

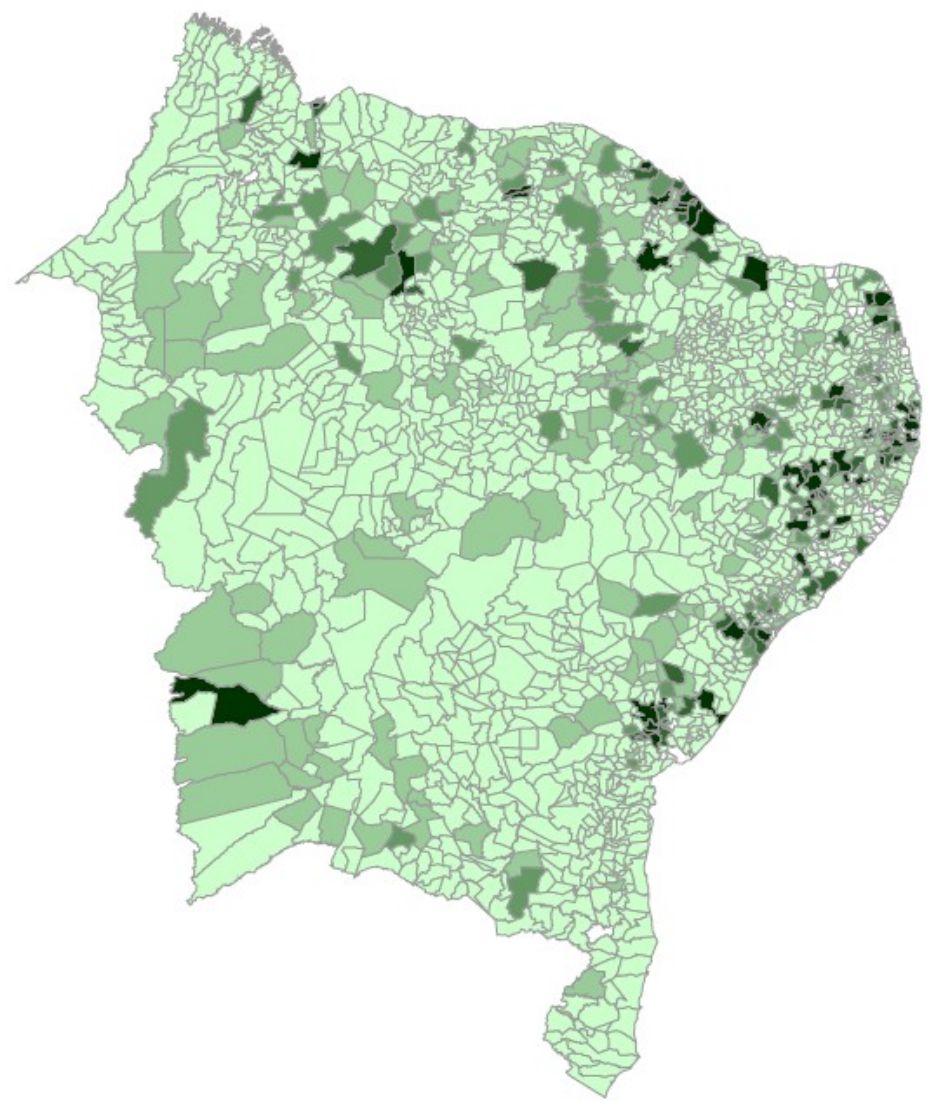


ANEXO 6 - MAPA DA DISTRIBUIÇÃO DOS REBANHO SUÍNOS NO NORDESTE -

\section{E9IBGE}

Espécie de efetivo - Suínos - Número de cabeças

Unidade: Cabecas
Estados: MA, PI, CE, RN, PB, PE, AL, SE, BA

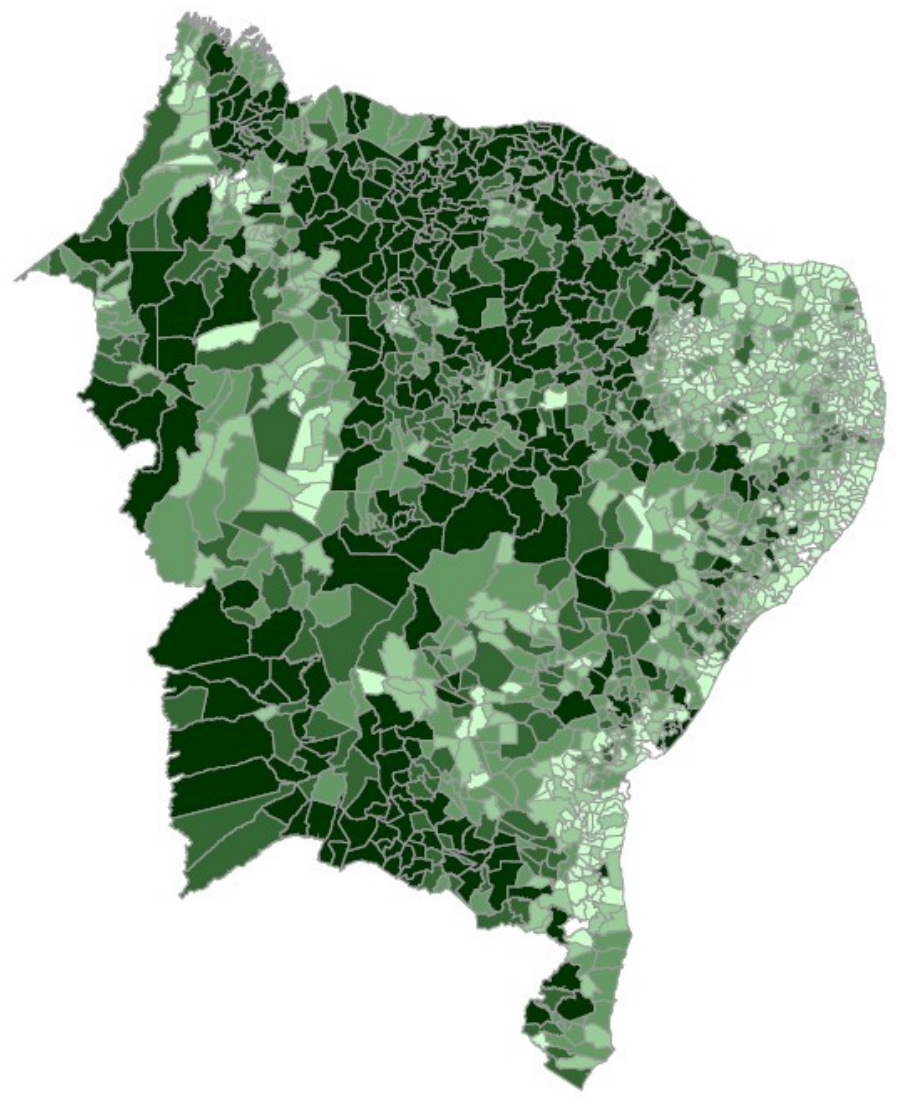


ANEXO 7 -Mapa dos Estabelecimentos Produtores de Leite - 2006

\section{BIIBGE}

Número de estabelecimentos agropecuários que produziram leite no ano

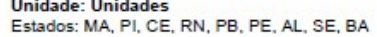

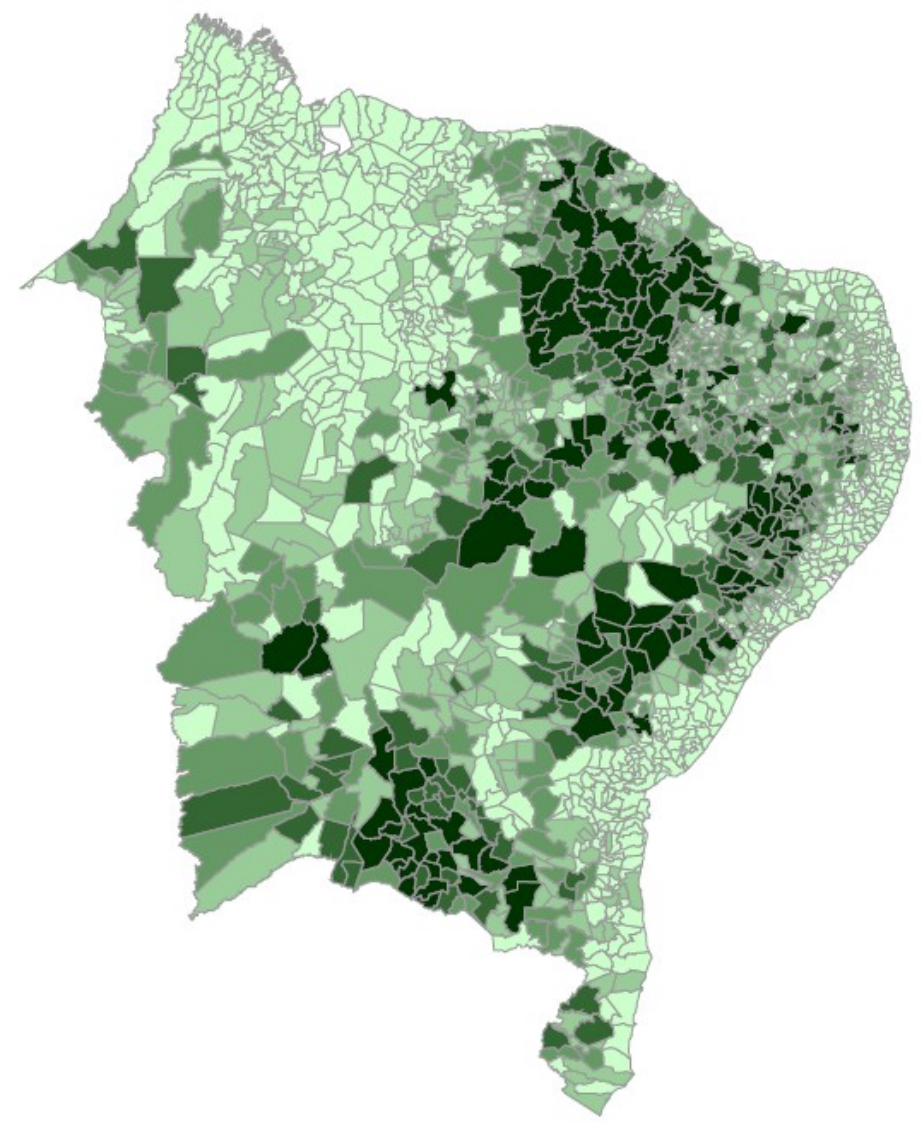

Censo Agropecuário: Fonte: Censo Agropecuário 2006. NOTA: Os dados com menos de 3 (três) informantes estão desidentifio 
ANEXO 8 - Tabela de Produção Estadual de Cana-de-Açúcar 1974 - 2016

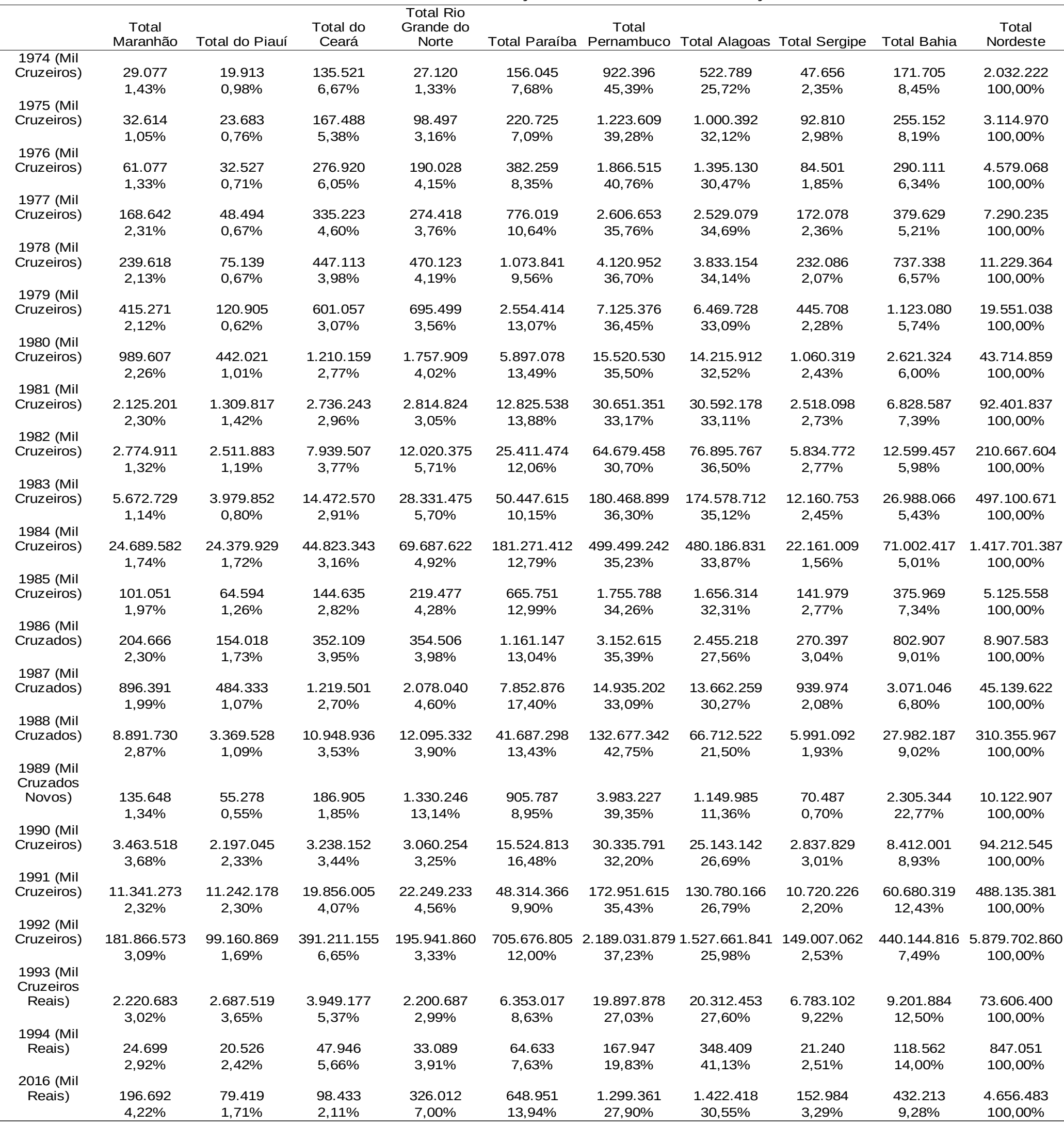

Dados: SIDRA-IBGE 
Anexo 9 - Quadro de Produção Acadêmicas de Manoel Correia de Andrade -

\begin{tabular}{|c|c|c|c|c|c|}
\hline $\begin{array}{l}\text { Livros e } \\
\text { artigos }\end{array}$ & Edições & Ano & Livros e artigos & Edições & Ano \\
\hline $\begin{array}{l}\text { A Terra e o } \\
\text { Homem no } \\
\text { Nordeste }\end{array}$ & 8 & $\begin{array}{l}1963 ; 1964 ; \\
1973 ; 1980 ; \\
19801986 ; \\
1998 ; 2005\end{array}$ & $\begin{array}{l}\text { Economia Brasileira: } \\
\text { Distribuição Espacial } \\
\text { das Atividades } \\
\text { Econômicas no Brasil }\end{array}$ & 1 & 1967 \\
\hline $\begin{array}{l}\text { Geografia do } \\
\text { Brasil, } 3^{a} \\
\text { Série ginasial. }\end{array}$ & 20 & Até 1964 & $\begin{array}{c}\text { Geografia, Região e } \\
\text { Desenvolvimento }\end{array}$ & 3 & 1967; 1971; 1977 \\
\hline $\begin{array}{c}\text { Pernambuco } \\
\text { e a Revolta } \\
\text { de Pinto } \\
\text { Madeira }\end{array}$ & 1 & 1953 & $\begin{array}{c}\text { O Homem e a Cana- } \\
\text { de-açúcar no Vale do } \\
\text { Siriji }\end{array}$ & 1 & 1967 \\
\hline $\begin{array}{c}\text { Geografia } \\
\text { Geral para } 1^{a} \\
\text { Série Ginasial }\end{array}$ & 30 & Até 1965 & $\begin{array}{c}\text { La Région Cotiére } \\
\text { Semi-aride de Nord- } \\
\text { Est du Brasil }\end{array}$ & 1 & 1967(mimeografado) \\
\hline $\begin{array}{c}\text { Geografia } \\
\text { Geral para } 2^{a} \\
\text { Série ginasial. }\end{array}$ & 65 & Até 1980 & $\begin{array}{l}\text { Três Ensaios Sobre a } \\
\text { Realidade Nordestina. }\end{array}$ & 1 & 1967 \\
\hline
\end{tabular}




\begin{tabular}{|c|c|c|c|c|c|}
\hline $\begin{array}{c}\text { O Agreste } \\
\text { Oriental de } \\
\text { Pernambuco }\end{array}$ & 1 & 1967 & $\begin{array}{c}\text { Geografia } \\
\text { Econômica Do } \\
\text { Nordeste }\end{array}$ & 5 & $\begin{array}{c}1970 ; 1974 ; \\
1977 ; 1987 ; \\
1998\end{array}$ \\
\hline $\begin{array}{l}\text { Anadia: Um } \\
\text { Município } \\
\text { Alagoano }\end{array}$ & 1 & 1967 & $\begin{array}{c}\text { L'industrialization } \\
\text { et le probléme } \\
\text { agraire comme } \\
\text { agentes moteurs } \\
\text { et de treinage de } \\
\text { la croissance } \\
\text { brésilienne. }\end{array}$ & 1 & 1969 \\
\hline $\begin{array}{c}\text { Condições } \\
\text { Geográficas e } \\
\text { Desenvolvimen } \\
\text { to }\end{array}$ & 1 & 1967 & $\begin{array}{c}\text { Organização } \\
\text { Social e política } \\
\text { brasileira }\end{array}$ & 1 & 1969 \\
\hline $\begin{array}{l}\text { Sugestões para } \\
\text { a reforma } \\
\text { agrária. }\end{array}$ & 1 & 1969 & $\begin{array}{l}\text { O Nordeste e a } \\
\text { elaboração da } \\
\text { independência: o } \\
\text { processo de } \\
\text { ruptura de um } \\
\text { sistema. }\end{array}$ & 1 & 1972 \\
\hline $\begin{array}{c}\text { Geografia } \\
\text { Econômica do } \\
\text { Nordeste: O } \\
\text { Espaço e a } \\
\text { Economia } \\
\text { Nordestina. }\end{array}$ & 5 & $\begin{array}{c}1963 \\
\text { (mimeografada) } \\
; \text { 1970; 1974; } \\
1977 ; 1987\end{array}$ & $\begin{array}{c}\text { Aceleração e } \\
\text { freios do } \\
\text { desenvolvimento } \\
\text { brasileiro }\end{array}$ & 1 & 1972 \\
\hline
\end{tabular}




\begin{tabular}{|c|c|c|c|c|c|}
\hline $\begin{array}{c}\text { Movimentos } \\
\text { nativistas em } \\
\text { Pernambuco: } \\
\text { Setembrizada e } \\
\text { Novembrizada }\end{array}$ & 2 & 1971; 1998 & $\begin{array}{l}\text { A pecuária nos } \\
\text { gerais do norte } \\
\text { de Minas }\end{array}$ & 1 & 1975 \\
\hline $\begin{array}{c}\text { A indústria } \\
\text { vinheira no Sul } \\
\text { de Minas Gerais }\end{array}$ & 1 & 1972 & $\begin{array}{c}\text { Polarizações } \\
\text { para João } \\
\text { Pessoa }\end{array}$ & 1 & 1975 \\
\hline $\begin{array}{c}\text { Espaço, } \\
\text { Polarização e } \\
\text { Desenvolviment } \\
\text { o }\end{array}$ & 2 & & $\begin{array}{l}\text { Geografia } \\
\text { econômica }\end{array}$ & 11 & $\begin{array}{c}\text { 1972;1973;1974; } \\
\text { 1975;1976;1977; } \\
\text { 1981;1985;1988; } \\
\text { 1989;1992; }\end{array}$ \\
\hline $\begin{array}{c}\text { Nordeste } \\
\text { espaço e tempo }\end{array}$ & 1 & 1970 & $\begin{array}{c}\text { Planejamento de } \\
\text { espaço } \\
\text { geográfico }\end{array}$ & 1 & 1974 \\
\hline $\begin{array}{l}\text { Povoamento e } \\
\text { degradação do } \\
\text { meio de Natural }\end{array}$ & 1 & 1975 & $\begin{array}{c}\text { História } \\
\text { Econômica e } \\
\text { Administrações } \\
\text { no Brasil }\end{array}$ & 5 & $\begin{array}{c}\text { 1976;1977;1978; } \\
\text { 1979;1982 }\end{array}$ \\
\hline $\begin{array}{c}\text { A Problemática } \\
\text { agropecuária de } \\
\text { Pernambuco }\end{array}$ & 2 & $1972 ; 1975$ & $\begin{array}{c}\text { O Planejamento } \\
\text { Regional e o } \\
\text { Problema } \\
\text { Agrário no Brasil }\end{array}$ & 1 & 1976 \\
\hline $\begin{array}{l}\text { O Processo de } \\
\text { ocupação do } \\
\text { espaço regional } \\
\text { do nordeste }\end{array}$ & 1 & 1975 & $\begin{array}{c}\text { O Processo de } \\
\text { ocupação do } \\
\text { espaço } \\
\text { Pernambucano }\end{array}$ & 1 & 1977 \\
\hline $\begin{array}{c}\text { Os anos trinta } \\
\text { no Brasil }\end{array}$ & 1 & 1976 & $\begin{array}{c}\text { relações de } \\
\text { dependência } \\
\text { entre centro e } \\
\text { periferia em } \\
\text { área } \\
\text { metropolitanas: }\end{array}$ & 1 & 1977 \\
\hline
\end{tabular}




\begin{tabular}{|c|c|c|c|c|c|}
\hline $\begin{array}{c}\text { A dinâmica do } \\
\text { comércio } \\
\text { exterior do Brasil }\end{array}$ & 1 & 1977 & $\begin{array}{c}\text { Produção do } \\
\text { espaço e } \\
\text { regionalização } \\
\text { em pernambuco }\end{array}$ & 2 & 1981; 1982 \\
\hline $\begin{array}{c}\text { Dinâmica das } \\
\text { microregiões de } \\
\text { intensa atividade } \\
\text { migratória }\end{array}$ & 1 & 1980 & $\begin{array}{c}\text { Áreas de } \\
\text { domínio da } \\
\text { pecuária } \\
\text { extensiva e } \\
\text { semi-intensiva } \\
\text { na Bahia e norte } \\
\text { de Minas Gerais }\end{array}$ & 1 & 1982 \\
\hline $\begin{array}{c}\text { Espaço e } \\
\text { Urbanização }\end{array}$ & 1 & 1980 & $\begin{array}{c}\text { O problema da } \\
\text { terra e a questão } \\
\text { agrária em } \\
\text { Pernambuco }\end{array}$ & 1 & 1982 \\
\hline $\begin{array}{c}\text { Latifúndio e } \\
\text { reforma agrária } \\
\text { no Brasil }\end{array}$ & 1 & 1980 & $\begin{array}{l}\text { A propriedade } \\
\text { da terra e as } \\
\text { transformações } \\
\text { recentes da } \\
\text { agricultura } \\
\text { pernambucana. }\end{array}$ & 1 & 1982 \\
\hline $\begin{array}{c}\text { Agricultura e } \\
\text { Capitalismo }\end{array}$ & 1 & 1979 & $\begin{array}{c}\text { As alternativas } \\
\text { do Nordeste }\end{array}$ & 1 & 1983 \\
\hline $\begin{array}{c}\text { Recife: } \\
\text { problemática de } \\
\text { uma metrópole } \\
\text { de região } \\
\text { subdesenvolvida }\end{array}$ & 1 & 1979 & $\begin{array}{l}\text { A produção do } \\
\text { espaço norte- } \\
\text { riograndense }\end{array}$ & 4 & $1981-1995$ \\
\hline $\begin{array}{c}\text { 1930: a } \\
\text { atualidade da } \\
\text { Revolução }\end{array}$ & 1 & 1980 & $\begin{array}{l}\text { Geografia, } \\
\text { sociedade e } \\
\text { cultura }\end{array}$ & 1 & 1983 \\
\hline $\begin{array}{c}\text { Capital, estado e } \\
\text { industrialização } \\
\text { no nordeste }\end{array}$ & 1 & 1981 & $\begin{array}{c}\text { Projeto, } \\
\text { avaliação e } \\
\text { diagnóstico da } \\
\text { Geografia no } \\
\text { Brasil }\end{array}$ & 1 & 1983 \\
\hline
\end{tabular}




\begin{tabular}{|c|c|c|c|c|c|}
\hline $\begin{array}{c}\text { Nordeste: a } \\
\text { reforma agrária } \\
\text { ainda é } \\
\text { necessária? }\end{array}$ & 1 & 1981 & $\begin{array}{c}\text { Tradição e } \\
\text { mudança: } \\
\text { Organização do } \\
\text { espaço rural e } \\
\text { urbano na área } \\
\text { de irrigação do } \\
\text { submédio São } \\
\text { Francisco }\end{array}$ & 1 & 1983 \\
\hline $\begin{array}{c}\text { A prioridade } \\
\text { nacional para a } \\
\text { agricultura e o } \\
\text { Nordeste }\end{array}$ & 1 & 1981 & $\begin{array}{c}\text { Ensaios sobre a } \\
\text { realidade } \\
\text { maranhense }\end{array}$ & 1 & 1984 \\
\hline $\begin{array}{c}\text { geografia geral e } \\
\text { do Brasil, para } 2^{\circ} \\
\text { grau e } \\
\text { preparação aos } \\
\text { vestibulares }\end{array}$ & 1 & 1984 & $\begin{array}{c}\text { Escravidão e } \\
\text { trabalho "livre" no } \\
\text { Nordeste } \\
\text { açucareiro }\end{array}$ & 1 & 1985 \\
\hline $\begin{array}{l}\text { Poder político e } \\
\text { produção do } \\
\text { espaço }\end{array}$ & 1 & 1984 & $\begin{array}{c}\text { Tendências e } \\
\text { possibilidades do } \\
\text { desenvolvimento } \\
\text { do Nordeste em } \\
\text { seca: Exposição } \\
\text { e debates }\end{array}$ & 1 & 1985 \\
\hline Sertão sul & 1 & 1984 & $\begin{array}{l}\text { O caso do } \\
\text { Nordeste } \\
\text { brasileiro }\end{array}$ & 1 & 1986 \\
\hline $\begin{array}{c}\text { Classes sociais } \\
\text { e agricultura no } \\
\text { Nordeste }\end{array}$ & 1 & 1985 & $\begin{array}{c}\text { Lutas } \\
\text { camponesas no } \\
\text { Nordeste }\end{array}$ & 2 & 1986; 2000 \\
\hline $\begin{array}{l}\text { O Primeiro Plano } \\
\text { Nacional de } \\
\text { Reforma Agrária } \\
\text { da Nova } \\
\text { Républica }\end{array}$ & 1 & 1986 & $\begin{array}{l}\text { o Nordeste e a } \\
\text { Nova República }\end{array}$ & 1 & 1987 \\
\hline $\begin{array}{c}\text { Abolição e } \\
\text { reforma agrária }\end{array}$ & 2 & $1987 ; 2001$ & $\begin{array}{c}\text { Área do sistema } \\
\text { canavieiro }\end{array}$ & 1 & 1988 \\
\hline
\end{tabular}




\begin{tabular}{|c|c|c|c|c|c|}
\hline $\begin{array}{c}\text { Geografia, } \\
\text { ciência da } \\
\text { sociedade: uma } \\
\text { introdução à } \\
\text { análise do } \\
\text { pensamento } \\
\text { geográfico. }\end{array}$ & 1 & 1987 & $\begin{array}{c}\text { Imperialismo e } \\
\text { Fragmentação } \\
\text { do Espaço }\end{array}$ & 1 & 1988 \\
\hline $\begin{array}{c}\text { Mineração no } \\
\text { Nordeste: } \\
\text { Depoimentos e } \\
\text { experiências }\end{array}$ & 1 & 1987 & $\begin{array}{c}\text { João Alfredo: o } \\
\text { estadista da } \\
\text { Abolição }\end{array}$ & 1 & 1988 \\
\hline $\begin{array}{l}\text { Nordeste: } \\
\text { Alternativas da } \\
\text { agricultura }\end{array}$ & 1 & 1988 & $\begin{array}{c}\text { Usinas de } \\
\text { açúcar e } \\
\text { destilarias no } \\
\text { Rio Grande do } \\
\text { Norte e na } \\
\text { Paraíba: agro- } \\
\text { indústria } \\
\text { canavieira e a } \\
\text { produção do } \\
\text { espaço }\end{array}$ & 1 & 1988 \\
\hline $\begin{array}{c}\text { O Nordeste e a } \\
\text { questão regional }\end{array}$ & 1 & 1988 & $\begin{array}{c}\text { O Brasil e a } \\
\text { África }\end{array}$ & 1 & 1989 \\
\hline $\begin{array}{c}\text { A Revolução de } \\
\text { 30: da República } \\
\text { Velha ao Estado } \\
\text { Novo }\end{array}$ & 1 & 1988 & $\begin{array}{c}\text { O Brasil e a } \\
\text { América Latina }\end{array}$ & 9 & $\begin{array}{c}\text { 1989;1990; } \\
\text { 1991;1994;1996; } \\
\text { 1997;1999;2000; } \\
2002\end{array}$ \\
\hline $\begin{array}{c}\text { Caminhos e } \\
\text { Descaminhos da } \\
\text { Geografia }\end{array}$ & 2 & $1989 ; 1994$ & $\begin{array}{c}1964 \text { e o } \\
\text { Nordeste: } \\
\text { Golpe, } \\
\text { revolução e } \\
\text { contra-revolução }\end{array}$ & 1 & 1989 \\
\hline $\begin{array}{c}\text { Geopolítica do } \\
\text { Brasil }\end{array}$ & 3 & $1989 ; 2007$ & $\begin{array}{c}\text { A agroindústria } \\
\text { canavieira e a } \\
\text { organização do } \\
\text { espaço: } \\
\text { contribuição à } \\
\text { história das } \\
\text { usinas de } \\
\text { açúcar de } \\
\text { Sergipe }\end{array}$ & 1 & 1990 \\
\hline $\begin{array}{l}\text { História das } \\
\text { Usinas de } \\
\text { Açúcar de } \\
\text { Pernambuco }\end{array}$ & 1 & 1989 & $\begin{array}{c}\text { Comércio } \\
\text { internacional e } \\
\text { ocupação do } \\
\text { território no } \\
\text { Brasil }\end{array}$ & 1 & 1990 \\
\hline
\end{tabular}




\begin{tabular}{|c|c|c|c|c|c|}
\hline $\begin{array}{c}\text { Departamento } \\
\text { de estradas de } \\
\text { rodagem, } 40 \\
\text { anos a serviço } \\
\text { de Pernambuco }\end{array}$ & 1 & 1990 & $\begin{array}{l}\text { O povo e o } \\
\text { poder }\end{array}$ & 1 & 1991 \\
\hline $\begin{array}{l}\text { O minério de } \\
\text { tungstênio no } \\
\text { Nordeste do } \\
\text { brasil }\end{array}$ & 1 & 1990 & $\begin{array}{c}\text { A produção de } \\
\text { cassiterita no } \\
\text { Norte e } \\
\text { Nordeste do } \\
\text { Brasil }\end{array}$ & 1 & 1991 \\
\hline $\begin{array}{l}\text { A cassiterita } \\
\text { nas regiões } \\
\text { Norte e } \\
\text { nordeste do } \\
\text { Brasil }\end{array}$ & 1 & 1991 & $\begin{array}{l}\text { Secretária da } \\
\text { Fazenda; um } \\
\text { século de } \\
\text { história }\end{array}$ & 1 & 1991 \\
\hline $\begin{array}{c}\text { o Crescimento } \\
\text { com miséria é } \\
\text { uma agressão } \\
\text { ao homem e á } \\
\text { natureza }\end{array}$ & 1 & 1991 & $\begin{array}{c}\text { A Itália no } \\
\text { Nordeste: } \\
\text { contribuição } \\
\text { italiana ao } \\
\text { Nordeste do } \\
\text { Brasil }\end{array}$ & 1 & 1992 \\
\hline $\begin{array}{c}\text { Usinas e } \\
\text { Destilarias nas } \\
\text { Alagoas }\end{array}$ & 2 & $1992 ; 2010$ & \begin{tabular}{|c|} 
Modernização e \\
pobreza: a \\
expansão da \\
agroindústria \\
canavieira e seu \\
impacto \\
ecológico e \\
social
\end{tabular} & 1 & 1994 \\
\hline $\begin{array}{c}\text { Uma geografia } \\
\text { para o século } \\
\text { XXI }\end{array}$ & 2 & $1993 ; 1994$ & $\begin{array}{l}\text { O Sentido da } \\
\text { colonização }\end{array}$ & 1 & 1994 \\
\hline $\begin{array}{l}\text { O desafio } \\
\text { ecológico: } \\
\text { utopia e } \\
\text { realidade }\end{array}$ & 1 & 1994 & $\begin{array}{c}\text { A Questão do } \\
\text { Território no } \\
\text { Brasil }\end{array}$ & 2 & $1995 ; 2004$ \\
\hline $\begin{array}{c}\text { A Revolução } \\
\text { Pernambucana } \\
\text { de } 1817\end{array}$ & 1 & 1995 & $\begin{array}{l}\text { Vencedores e } \\
\text { vencidos: O } \\
\text { movimento de } \\
1964 \text { em } \\
\text { Pernambuco }\end{array}$ & 1 & 2004 \\
\hline
\end{tabular}




\begin{tabular}{|c|c|c|c|c|c|}
\hline $\begin{array}{l}\text { O Território do } \\
\text { Sal: } A \\
\text { exploração do } \\
\text { sal marinho e a } \\
\text { produção do } \\
\text { espaço } \\
\text { geográfico no } \\
\text { Rio Grande do } \\
\text { Norte }\end{array}$ & 1 & 1995 & $\begin{array}{c}\text { A Federação } \\
\text { brasileira: Uma } \\
\text { análise } \\
\text { geopolítica geo- } \\
\text { social }\end{array}$ & 2 & $1999 ; 2003$ \\
\hline $\begin{array}{l}\text { Geografia: } \\
\text { Ciência da } \\
\text { Sociedade }\end{array}$ & 1 & 2008 & $\begin{array}{c}\text { Josué de Castro } \\
\text { e o Brasil }\end{array}$ & 1 & 2003 \\
\hline $\begin{array}{c}\text { Gilberto Freyre e } \\
\text { os grandes } \\
\text { desafios do } \\
\text { século XX }\end{array}$ & 1 & 2002 & $\begin{array}{c}\text { A trajetória do } \\
\text { Brasil } 1500 \text { a } \\
2000\end{array}$ & 1 & 2000 \\
\hline $\begin{array}{l}\text { Seca e o Poder; } \\
\text { Entrevista com } \\
\text { Celso Furtado }\end{array}$ & 2 & 2001 & $\begin{array}{c}\text { As Raízes do } \\
\text { Separatismo no } \\
\text { Brasil }\end{array}$ & 1 & 1999 \\
\hline $\begin{array}{l}\text { Formação } \\
\text { Histórica da } \\
\text { Nacionalidade } \\
\text { Brasileira }\end{array}$ & 1 & 2000 & $\begin{array}{c}\text { A Questão } \\
\text { nacional e os } \\
\text { desequilíbrios de } \\
\text { desenvolvimento } \\
\text { regional }\end{array}$ & 1 & 1997 \\
\hline $\begin{array}{c}\text { Joaquim Nabuco } \\
\text { O Parlamentar, } \\
\text { O Escritor e O } \\
\text { Diplomata }\end{array}$ & 1 & 2001 & $\begin{array}{c}\text { O Brasil e a } \\
\text { Questão Agrária }\end{array}$ & 1 & 2002 \\
\hline $\begin{array}{l}\text { Atlas Escolar de } \\
\text { Pernambuco }\end{array}$ & 1 & 2002 & $\begin{array}{c}\text { A cana-de- } \\
\text { açúcar na } \\
\text { Região da Mata } \\
\text { pernambucana }\end{array}$ & 1 & 2002 \\
\hline $\begin{array}{l}\text { Os Italianos no } \\
\text { Trópico }\end{array}$ & 1 & 2002 & $\begin{array}{l}\text { Vencidos e } \\
\text { Vencedores }\end{array}$ & 1 & 2004 \\
\hline $\begin{array}{l}\text { Recife, uma } \\
\text { Trajetória } \\
\text { Secular }\end{array}$ & 1 & 2003 & $\begin{array}{l}\text { Pernambuco. } \\
\text { Cinco séculos } \\
\text { de colonização }\end{array}$ & 1 & 2004 \\
\hline $\begin{array}{c}\text { Formação } \\
\text { Territorial e } \\
\text { Econômica do } \\
\text { Brasil }\end{array}$ & 1 & 2003 & & & \\
\hline
\end{tabular}

